The University of Maine

\title{
DigitalCommons@UMaine
}

Electronic Theses and Dissertations

Fogler Library

Fall 12-15-2017

\section{Evaluating Potential for Water Quality Decline in Maine Lakes}

\author{
Kaci N. Fitzgibbon \\ University of Maine, kaci.fitzgibbon@maine.edu
}

Follow this and additional works at: https://digitalcommons.library.umaine.edu/etd

Part of the Biogeochemistry Commons, Environmental Monitoring Commons, Fresh Water $\underline{\text { Studies Commons, Sustainability Commons, and the Water Resource Management Commons }}$

\section{Recommended Citation}

Fitzgibbon, Kaci N., "Evaluating Potential for Water Quality Decline in Maine Lakes" (2017). Electronic Theses and Dissertations. 2780. https://digitalcommons.library.umaine.edu/etd/2780

This Open-Access Thesis is brought to you for free and open access by DigitalCommons@UMaine. It has been accepted for inclusion in Electronic Theses and Dissertations by an authorized administrator of DigitalCommons@UMaine. For more information, please contact um.library.technical.services@maine.edu. 


\title{
EVALUATING POTENTIAL FOR WATER QUALITY DECLINE IN MAINE LAKES
}

\author{
By \\ Kaci Fitzgibbon
}

B.S. Kent State University, 2015

\author{
A THESIS \\ Submitted in Partial Fulfillment of the \\ Requirements for the Degree of \\ Master of Science \\ (in Earth and Climate Sciences)
}

The Graduate School

The University of Maine

December 2017

Advisory Committee:

Aria Amirbahman, Professor of Civil and Environmental Engineering, CoAdvisor

Stephen Norton, Professor Emeritus of Earth and Climate Sciences, Co-Advisor

Sean Smith, Associate Professor of Earth and Climate Sciences 


\title{
EVALUATING POTENTIAL FOR WATER QUALITY DECLINE IN MAINE
}

\author{
LAKES \\ By Kaci Fitzgibbon
}

Thesis Co-Advisors: Dr. Aria Amirbahman and Dr. Stephen Norton

\author{
An Abstract of the Thesis Presented \\ in Partial Fulfillment of the Requirements for the \\ Degree of Master of Science \\ (in Earth and Climate Sciences) \\ December 2017
}

Understanding lake vulnerability with respect to eutrophication and loss of water quality is important for sustainability of aquatic ecosystems. This project aims at identifying and quantifying the effects of relevant physiochemical, climate, and watershed characteristics on lake vulnerability in order to develop management decision tools for the Maine Department of Environmental Protection (MEDEP). In a changing chemical and physical environment, using independent variables from each of these categories and then relating them to the summer lake epilimnetic phosphorus $(\mathrm{P})$ concentrations allows for development of models to inform stakeholders of lake vulnerability to eutrophication problems.

We studied 24 lakes covering a range of trophic states (oligotrophic to mesotrophic) in Maine, USA. The lakes are classified as either dimictic or polymictic and may develop anoxic hypolimnia during stratification. Lake water samples were collected twice in June and August 2015, and analyzed for a variety of elements, with a primary focus on P. August epilimnetic P ranged from 1.9 to $21.0 \mu \mathrm{g} / \mathrm{L}$ (henceforth ppb). Sediment samples from the deepest point were collected in June 2015, and were sequentially extracted and analyzed for $\mathrm{P}$, aluminum (Al), and iron (Fe). The results show 
that lakes with sediment having a $\mathrm{NaOH}$-extractable $\mathrm{Al}$ to dithionite-reducible Fe ratio $\left(\mathrm{Al}_{\mathrm{NaOH}}: \mathrm{Fe}_{\mathrm{BD}}\right)>3$ and a $\mathrm{NaOH}$-extractable $\mathrm{Al}$ to dithionite-reducible $\mathrm{P}$ ratio $\left(\mathrm{Al}_{\mathrm{NaOH}}: \mathrm{P}_{\mathrm{BD}}\right)$ $>25$ are less susceptible to internal $\mathrm{P}$ release, and have lower epilimnetic $\mathrm{P}$ concentrations. Ratios can thereby be used as sediment indicators for hypolimnetic P release under anoxic conditions.

Three types of regression models (regression tree analysis, multiple linear regression (MLR), and quantile regression $(\mathrm{QR})$ ) were developed in order to broaden understanding of different aspects impacting lake eutrophication using data from the 24 study lakes that represented relevant lake physiochemical, climate, and watershed characteristics. A larger database of lakes from the Maine Department of Environmental Protection (96), and the Lake Environment Association (23) were then used to validate the models by analyzing the goodness of fit. The regression tree analysis was performed to detect dominant drivers in relation to the August epilimnetic P concentrations, revealing that to best predict the lake epilimnetic $\mathrm{P}$, parameters representing physiochemical, climate and watershed characteristics are necessary independent variables. Of the approaches tested for MLR, the best fits to the observed data were obtained by one or more physiochemical variables and one watershed variable $\left(\mathrm{R}^{2}>\right.$ 0.78). Regression quantiles were used to estimate changes in epilimnetic $\mathrm{P}$ as a function of the agriculture area: watershed area $(\mathrm{Ag}: \mathrm{WA})$ ratio ranked by sediment $A l_{\mathrm{NaOH}}: \mathrm{P}_{\mathrm{BD}}$ and area depth $\left(Z_{a v g}\right)$, all parameters that were shown to be important predictors in the MLR models. The structure of QR is robust for developing nutrient reduction targets for lake management. Using this approach, we determined that the reduction in Ag:WA to meet a specific epilimnetic $\mathrm{P}$ target (15 ppb) should be the first priority to mitigate 
eutrophication in Maine lakes. Using multiple regression models to identify and quantify factors that influence lake eutrophication allows us to classify susceptible lakes and inform stakeholders about appropriate practices for lake stewardship. 


\section{ACKNOWLEDGEMENTS}

This research was funded by grants from the Senator George J. Mitchell Center for Sustainability Solutions, the Maine Outdoor Heritage Fund, and the Maine Department of Environmental Protection (DEP). I thank the DEP for providing field equipment and sampling assistance throughout my research, with a special thanks to Linda Bacon, Jeff Dennis, Jeremy Deeds, and Douglas Suitor for their criticism and support along the way. I thank all of the people who helped me in the field aspects; Josh Noll, Mark Dennis, Douglas Suitor, Denise Blanchette, volunteers in the Maine Volunteer Lake Monitoring Program (VLMP), and Scott Williams (Executive Director of the Maine VLMP). Additionally, I thank Colin Holme (Assistant Director of Lakes Environmental Association, LEA) for providing a dataset of additional lakes.

I thank the Sawyer Environmental Chemistry Laboratory at the University of Maine for providing use of the laboratory. I thank Benjamin Burpee and Heather Doolittle, for their time explaining laboratory procedures for the study, and also Mike Handley for making sure I received the required laboratory space and equipment.

I thank my advisory committee: Drs. Aria Amirbahman, Steve Norton, and Sean Smith, for their endless supply of hypotheses and for helping me to see my research from another perspective. I give special thanks to my co-advisor, Dr. Aria Amirbahman for constantly challenging me to be a better researcher and for his guidance. I thank Professor Bill Halteman for his insight into the statistical realm. I thank my fellow officemates for their support and willingness to read multiple sections of my thesis. Finally, I am thankful to my family and friends who have supported and encouraged me throughout. 


\section{TABLE OF CONTENTS}

ACKNOWLEGEMENTS ..............................................................

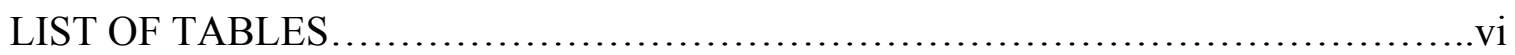

LIST OF FIGURES......................................................vii

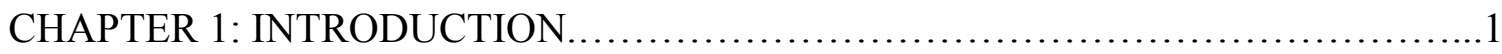

1.1 External Loading.................................................

1.2 Internal Phosphorus Loading to Lakes..................................2

1.2.1 Chemical Mechanisms........................................

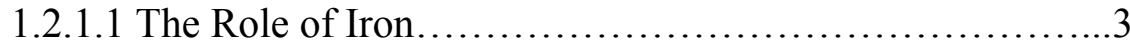

1.2.1.2 The Role of Aluminum.............................4

1.2.2 Biological Mechanisms.....................................6

1.2.3 Physical Mechanisms.....................................6

1.3 Internal Mixing...................................................

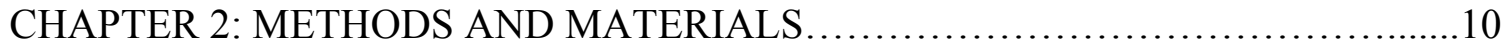

2.1 Field Sites.................................................... 10

2.2 Aqueous Collection and Analysis................................... 12

2.3 Sediment Collection and Analysis.................................. 12

2.4 Pre-existing Data Compilation.................................... 14

2.5 Model Development................................................. 16

2.5.1 Regression Tree Analysis................................17

2.5.2 Linear Regression Analysis................................19

2.5.3 Percentile Selection Quantile Regression Analysis................22 


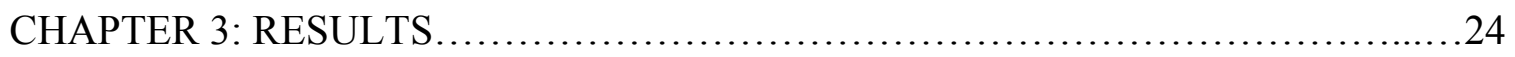

3.1 Physiochemical Characteristics......................................24

3.1.1 Morphometric Characteristics..................................24

3.1.2 Surficial Sediment Fractionation...............................26

3.1.3 Sediment Phosphorus........................................27

3.1.4 Sediment Iron.............................................. 27

3.1.5 Sediment Aluminum........................................27

3.1.6 The $\mathrm{Al}_{\mathrm{NaOH}}: \mathrm{Fe}_{\mathrm{BD}}$ and $\mathrm{Al}_{\mathrm{NaOH}}: \mathrm{P}_{\mathrm{BD}}$ Ratios........................28

3.1.7 Water Chemistry ................................................

3.2 Climate Factors.......................................................... 34

3.3 Watershed Characteristics............................................... 37

3.4 Statistical Modeling Results...........................................38

3.4.1 Regression Tree............................................... 38

3.4.2 Multiple Linear Regression.....................................41

3.4.3 Quantile Regression.........................................47

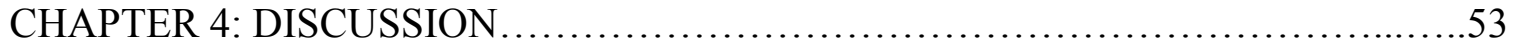

4.1 Regression Tree Model...............................................53

4.2 Multiple Linear Regression Models........................................55

4.3 Percentile Selection-Quantile Regression...............................58

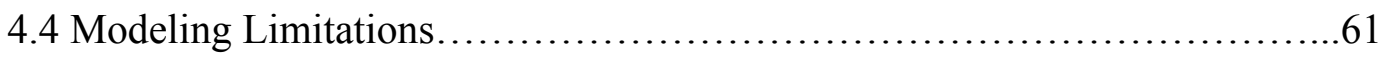

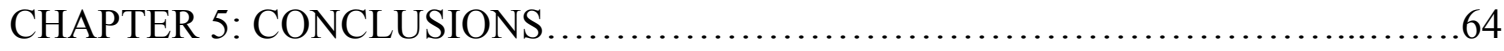

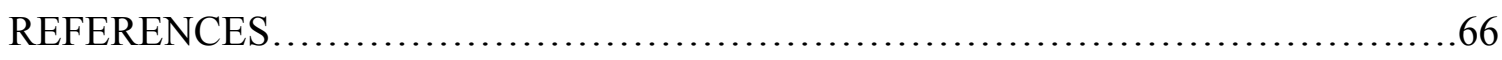

APPENDIX A: MIDAS IDENTIFICATION ......................................72 
APPENDIX B: SEDIMENT AND WATER CHEMISTRY DATA....................75

APPENDIX C: MODEL PARAMETERS........................................ 112

APPENDIX D: LAND COVER DATA....................................... 126

APPENDIX E: PRECIPITATION DATA....................................146

APPENDIX F: FIELD MAPS AND LOCATION ............................... 150

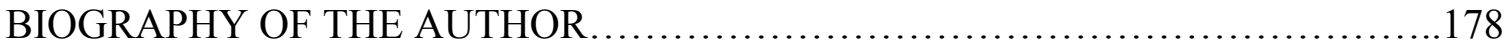




\section{LIST OF TABLES}

Table 2.1: Selected Properties of the 2015 Lakes................................... 11

Table 2.2: Data from the Study (2015) and other organizations (DEP + LEA).........21

Table 3.1: Multiple Linear Regression Equation Results from the 2015 Study Lakes....43

Table 3.2: Multiple Linear Regression Equation Coefficients.........................44

Table A1: Midas Identification.............................................. 72

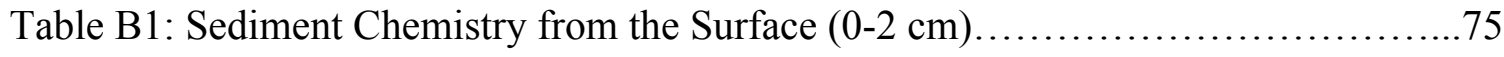

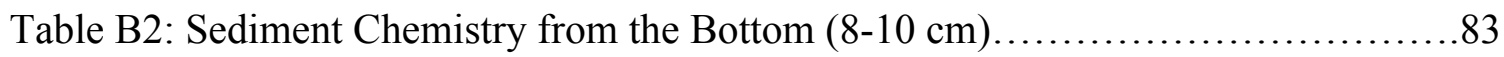

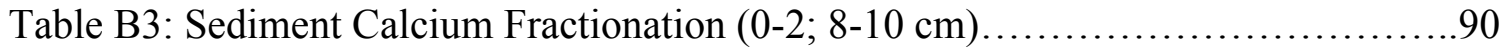

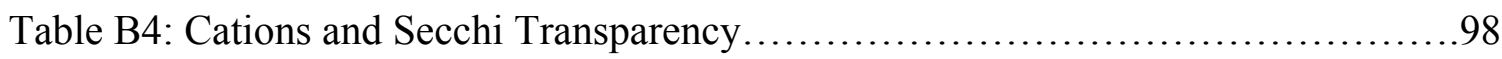

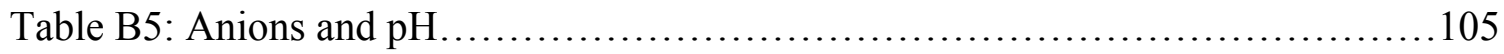

Table C1.1: Significant Parameters: Watershed and Chemistry......................112

Table C1.2: Significant Parameters: Physiochemical and Climate...................119

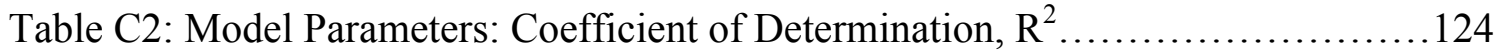

Table D1: Land cover Identification Key................................... 127

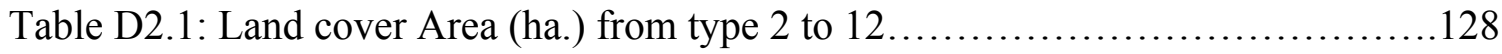

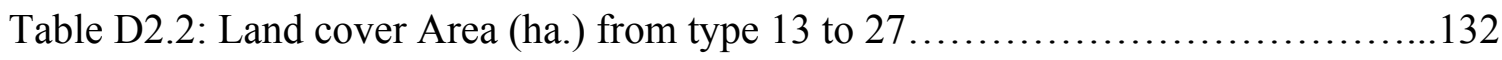

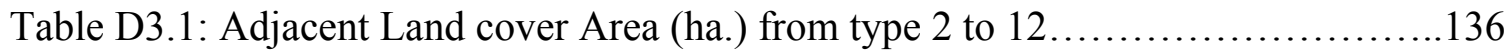

Table D3.2: Adjacent Land cover Area (ha.) from type 13 to $26 \ldots \ldots \ldots \ldots \ldots \ldots \ldots \ldots 140$

Table D4: Road, Direct Watershed, and Lake Areas (ha.).......................... 144

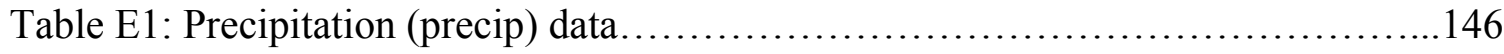

Table F1: Latitude and Longitude of Sample Sites.............................151 


\section{LIST OF FIGURES}

Figure 3.1: The Osgood Index (Eq. 1) versus the August epilimnetic P................25

Figure 3.2: The area-averaged depth (Eq. 2) versus the August epilimnetic P...........25

Figure 3.3: Sediment $\mathrm{Al}_{\mathrm{NaOH}}: \mathrm{Fe}_{\mathrm{BD}}$ versus Epilimnetic P.........................

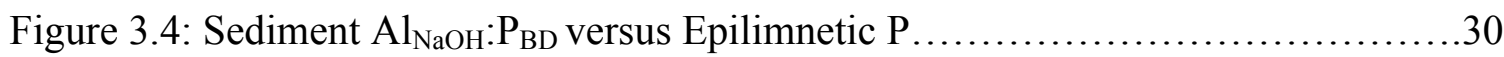

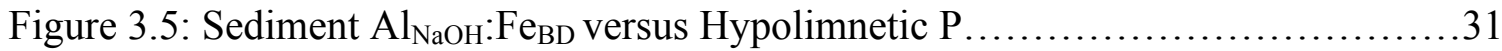

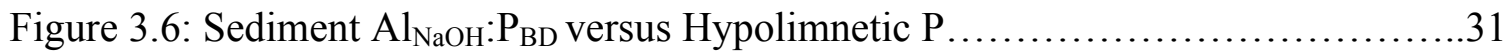

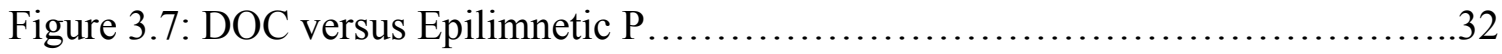

Figure 3.8: Epilimnetic pH versus Epilimnetic P................................. 33

Figure 3.9: Hypolimnetic Temperature versus Epilimnetic P.......................34

Figure 3.10: Schmidt Stability versus Epilimnetic P...............................

Figure 3.11: Ag:WA Ratio versus Epilimnetic P..................................

Figure 3.12: Regression Tree Analysis for Epilimnetic P........................40

Figure 3.13: The Multiple Linear Regression Model Determined by AIC ..............45

Figure 3.14: The Multiple Linear Regression Model Determined by RSS..............46

Figure 3.15: Ag:WA, lower $75^{\text {th }}$ percentile $\mathrm{Al}_{\mathrm{NaOH}}: \mathrm{P}_{\mathrm{BD}}$ versus $\log$ epilimnetic $\mathrm{P} \ldots \ldots . .49$

Figure 3.16: Ag:WA, lower $50^{\text {th }}$ percentile $\mathrm{Al}_{\mathrm{NaOH}}: \mathrm{P}_{\mathrm{BD}}$ versus $\log$ epilimnetic $\mathrm{P} \ldots \ldots . .50$

Figure 3.17: Ag:WA, lower $75^{\text {th }}$ percentile $Z_{\text {avg }}$ versus $\log$ epilimnetic $\mathrm{P} \ldots \ldots \ldots \ldots . . . .51$

Figure 3.18: Ag:WA, lower $50^{\text {th }}$ percentile $Z_{\text {avg }}$ versus $\log$ epilimnetic $\mathrm{P} \ldots \ldots \ldots \ldots \ldots . . .52$

Figure B1: Sequential Extraction (P, Fe, Al) of Sediment Cores.............................92

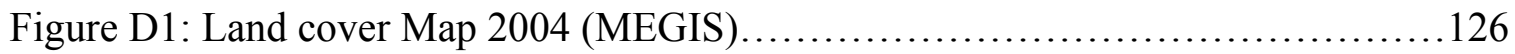

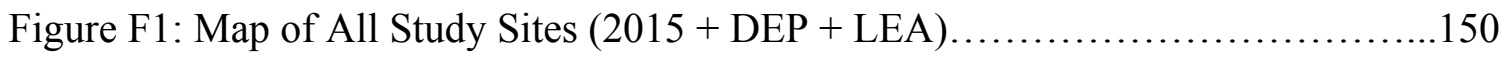

Figure F2: The Land Cover Type for the 2015 Study Sites.........................154 


\section{CHAPTER 1: INTRODUCTION}

Phosphorus $(\mathrm{P})$ is a limiting nutrient in many freshwater ecosystems. Small amounts of P are beneficial to freshwater ecosystems; however, excessive amounts are the leading cause of eutrophication, resulting from water pollution (Wetzel, 2001). Eutrophication occurs when a plethora of nutrients results in the explosive growth of aquatic plants and algae. Lakes offer multiple ecosystem services such as drinking water supplies, aquatic habitats, and recreational uses. A new field of sustainability science has emerged, which has a goal of understanding the fundamental interactions between nature and society. Sustainability research focuses on promoting the education of society to navigate toward a transition to sustainability (Kates et al., 2001). With this goal in mind, this study has two broad goals: first, to identify and advance our understanding of the roles of various watershed and lake characteristics and their effect in rendering lakes vulnerable to eutrophication; second, to preserve water quality in lakes by considering the active management of activities within the watershed to sustain water quality. This thesis provides guidance as to which characteristics make lakes susceptible to eutrophication and how best to make choices that influence lake behavior in a positive manner.

\subsection{External Loading}

The primary source of phosphorus $(\mathrm{P})$ from undisturbed watersheds is the chemical weathering of soils and bedrock that contain the mineral apatite $\left(\mathrm{Ca}_{5}\left(\mathrm{PO}_{4}\right)_{3}(\mathrm{OH}\right.$, F, Cl); Filippelli, 2008). P may be transported in water in particulate organic and inorganic phases, and dissolved organic or dissolved inorganic forms (Wetzel, 2001). P mobilization by dissolved organic carbon or soil acidification has been linked to the 
mobilization of aluminum $(\mathrm{Al})$ and iron $(\mathrm{Fe})$ hydroxides $\left(\mathrm{Al}(\mathrm{OH})_{3}\right.$ and $\left.\mathrm{Fe}(\mathrm{OH})_{3}\right)$, due to desorption from secondary Al- and Fe-hydroxide surfaces in soil (Reinhardt et al., 2003). Acidification does not always directly correlate with an increase in Fe dissolution, indicating other factors such as changing redox conditions and elevated concentration of dissolved organic carbon may cause enhanced Fe mobilization (Reinhardt et al., 2003).

Anthropogenic activities create external inputs of $\mathrm{P}$ to surface water through agriculture, deforestation, industrial activities, water treatment plants, and urbanization. Intensified agriculture directly contributes to increased $\mathrm{P}$ export from the watershed through application of fertilizers and increased soil erosion (Dillon and Kirchner, 1975). Deforestation functions via two mechanisms to solubilize and mobilize P. First, burning converts P from plant matter into soluble ash. Second, enhanced erosion in the cropped areas transports surface soil rich in organic matter as well as secondary Al- and Fehydroxides (Filippelli, 2008). Land development of riparian zones, wetlands, and shorelines destroy natural buffer zones where $\mathrm{P}$ can be sequestered, increasing the delivery of P to lakes (Fisher and Acreman, 2004).

\subsection{Internal Phosphorus Loading to Lakes}

Einsele (1936) and Mortimer (1941) pioneered the concept of lake internal P cycling, introducing the process as an important mechanism contributing to eutrophication. Their work provided the paradigm in which oxygenated sediment retains P through adsorption to $\mathrm{Fe}(\mathrm{OH})_{3}$. Following the reductive dissolution of $\mathrm{Fe}(\mathrm{OH})_{3}$ under anaerobic conditions, $\mathrm{P}$ is released as bioavailable $\mathrm{PO}_{4}$ (Petticrew and Arocena, 2001; Amirbahman et al. 2003). P stored internally in the sediment accounts for the main 
summer P load in boreal lakes (Nürnberg, 2009) making it a significant factor when considering lake vulnerability. Internal P cycling involves a combination of chemical, biological, and physical processes (Boström et al., 1988; Nürnberg, 2009). Major chemical mechanisms include interaction of $\mathrm{P}$ with organic, secondary "mineral" phases, and primary mineral surfaces (Boström et al., 1988; Petticrew and Arocena, 2001; Homyak et al, 2014). Biological mechanisms include hyper-accumulation and release of P by bacteria and some algae species (Gächter et al., 1988; Barbiero and Welch, 1992; Khoshmanesh et al., 2001; Carey et al., 2014). Physical mechanisms include variations in temperature, thermal stratification, and induced mixing by altered lake circulation (Christophoridis and Fytianos, 2006; Hupfer and Lewandowski, 2008).

\subsubsection{Chemical Mechanisms}

\subsubsection{The Role of Iron}

A reducing environment in the hypolimnion occurs when oxygen is depleted by aerobic respiration of organic matter, resulting in the reduction of insoluble Fe(III) (as $\left.\mathrm{Fe}(\mathrm{OH})_{3}\right)$ in the upper sediment to soluble $\mathrm{Fe}(\mathrm{II})$, dissolution of the $\mathrm{Fe}(\mathrm{OH})_{3}$, and release of adsorbed $\mathrm{P}$ into the overlying hypolimnion. Oxygen depletion is influenced by the decomposition rate of organic matter, which is temperature dependent, and the onset of stratification that inhibits lake mixing (Nürnberg, 1995). The phosphate that is associated with the surface of $\mathrm{Fe}(\mathrm{OH})_{3}$ represents the upper estimate of potentially mobile $\mathrm{P}$ under reducing conditions (Rydin et al., 2000; Kopáček et al., 2005). In lakes in non-calcareous areas, $\mathrm{P}$ is largely associated with the surfaces of $\mathrm{Fe}(\mathrm{OH})_{3}$ and $\mathrm{Al}(\mathrm{OH})_{3}$, and organic matter. 
Amirbahman et al. (2003) estimated sediment $\mathrm{Fe}(\mathrm{OH})_{3}$ reductive dissolution rate by following rates of changes in hypolimnetic $\mathrm{Fe}(\mathrm{II}), \mathrm{SO}_{4}{ }^{2-}$, and $\mathrm{S}(-\mathrm{II})$ concentrations over time, in a study of 11 Maine lakes. Using these rates, they predicted sediment P flux into the water column. The measured and predicted hypolimnetic P fluxes agreed well, in all but two lakes; two outlier lakes had Fe fluxes similar to the high P lakes, but showed significantly lower P fluxes. A subsequent study showed that excess sediment $\mathrm{Al}(\mathrm{OH})_{3}$ in the two outlier lakes had effectively sequestered $\mathrm{P}$ and inhibited its release following the onset of anoxia (Lake et al., 2007).

\subsubsection{The Role of Aluminum}

Thermodynamically, $\mathrm{P}$ as orthophosphate adsorbs more favorably onto $\mathrm{Fe}(\mathrm{OH})_{3}$ than $\mathrm{Al}(\mathrm{OH})_{3}$. However, the $\mathrm{Al}(\mathrm{OH})_{3}$ surface effectively competes with the $\mathrm{Fe}(\mathrm{OH})_{3}$ surface for $\mathrm{P}$ adsorption in lake sediment with a high $\mathrm{Al}(\mathrm{OH})_{3}$ concentration, limiting $\mathrm{P}$ release into the water column under anoxic conditions (Kopáček et al., 2005; Homyak et al., 2014). $\mathrm{Al}$ is not a redox sensitive element. Thus, $\mathrm{Al}(\mathrm{OH})_{3}$ remains insoluble under anaerobic conditions provided that the hypolimnion $\mathrm{pH}$ remains between 5.5 and 8.5. $\mathrm{Al}(\mathrm{OH})_{3}$ has a high sorption capacity for P (Kopáček et al., 2000; Rydin et al., 2000). Under anaerobic conditions, available sites on $\mathrm{Al}(\mathrm{OH})_{3}$ surface allow for $\mathrm{P}$ liberated from $\mathrm{Fe}(\mathrm{OH})_{3}$ to be adsorbed (Kopáček et al, 2005; Hupfer and Lewandowski, 2008). Lake remediation by $\mathrm{Al}$ treatment (alum) has proven effective at lowering internal $\mathrm{P}$ loading potential because the $\mathrm{Al}$ addition can bind excess $\mathrm{P}$ in the hypolimnetic sediment, resulting in irreversible sequestration (Rydin et al., 2000; Jensen et al., 2015). Longevity and effectiveness of treatment depend on the lake morphometry, Al dose, and extent to 
which P export from the watershed has been reduced (Welch and Cooke, 1999; Huser et al., 2015).

Psenner et al. (1984) developed a 5-step sequential extraction method for sediment that estimates Fe-associated P and Al-associated P (steps 2 and 3). The extraction sequence has been broadly used in sediment-P research. The bicarbonatedithionite (BD) extractable $\mathrm{P}$ (step 2; section 2.3 ) represents the fraction of potentially mobile $\mathrm{P}$ associated with reducible $\mathrm{Fe}(\mathrm{OH})_{3}$. Kopáček et al. (2005) titrated lake sediment with dissolved $\mathrm{Al}$ in the laboratory. They proposed operational thresholds to estimate potential sediment $\mathrm{P}$ release following the reductive dissolution of $\mathrm{Fe}(\mathrm{OH})_{3}$ : (1) in step 2 and 3, if (1 M NaOH extractable $\mathrm{Al}) /(0.1 \mathrm{M}$ bicarbonate-dithionite (BD) extractable $\mathrm{Fe})$ ratio $\left(\mathrm{Al}_{\mathrm{NaOH}}: \mathrm{Fe}_{\mathrm{BD}}\right)$ is $>3$, or $(2)(1 \mathrm{M} \mathrm{NaOH}$ extractable $\mathrm{Al}) /(0.1 \mathrm{M}$ bicarbonatedithionite extractable $\mathrm{P})$ ratio $\left(\mathrm{Al}_{\mathrm{NaOH}}: \mathrm{P}_{\mathrm{BD}}\right)$ is $>25$, then $\mathrm{P}$ is effectively and irreversibly sequestered by sediment $\mathrm{Al}(\mathrm{OH})_{3}$ during anoxic events. The BD-extractable P represents the fraction of potentially mobile $\mathrm{P}$ associated with reducible $\mathrm{Fe}(\mathrm{OH})_{3}$. Measuring these ratios for lake sediment allows identification of lakes that are susceptible to internal $\mathrm{P}$ release following the onset of hypolimnetic anoxia (Lake et al., 2007; Homyak et al, 2014).

Lake et al. (2007) tested the model developed by Kopáček et al. (2005) on six dimictic (lake mixing pattern in which lakes mix twice per year) Maine lakes that developed summer hypolimnetic anoxia. Consistent with the model, they observed that lakes whose sediment equaled or exceeded the $\mathrm{Al}_{\mathrm{NaOH}}: \mathrm{Fe}_{\mathrm{BD}}>3$ and $\mathrm{Al}_{\mathrm{NaOH}}: \mathrm{P}_{\mathrm{BD}}>25$ ratios released negligible P. However, even though meeting one of these thresholds is sufficient for the inhibition of sediment $\mathrm{P}$ release, sediment conditions where $\mathrm{Al}_{\mathrm{NaOH}}: \mathrm{Fe}_{\mathrm{BD}}$ 
$<3$ and $\mathrm{Al}_{\mathrm{NaOH}}: \mathrm{P}_{\mathrm{BD}}<25$ ratios are not sufficient requirements for sediment $\mathrm{P}$ release (Lake et al., 2007). Significant sediment $\mathrm{P}$ release also requires the presence of an anoxic hypolimnion.

\subsubsection{Biological Mechanisms}

Bacteria can act as a catalyst to fuel anoxic conditions or can play a direct role in the storage and release of P (Boström et al., 1988; Khoshmanesh et al, 2001). Gächter et al. (1998) demonstrated that microorganisms can directly contribute significant amounts of $\mathrm{P}$ to a lake. Some cultures of microbes accumulate $\mathrm{P}$ as polyphosphate, and hydrolyze and release it following the onset of anoxia.

Alternatively, biological activity can assist, in addition to physical mixing, with the vertical mobility of $\mathrm{P}$ in the water column; for example, Gloeotrichia echinulate (Gloeotrichia) is a species of cyanobacteria present in oligotrophic lakes across the northeastern U.S. (Carey et al., 2014) and capable of P translocation in the water column by adjusting their buoyancy. Gloeotrichia hyper-accumulate P from the nutrient-rich bottom to the photic zone, and may contribute a significant portion of the internal loading of a lake (Barbiero and Welch, 1992).

\subsubsection{Physical Mechanisms}

Physical characteristics within the lake also affect internal P release. Lake shape, surface area, average depth, and surface area/volume ratio all affect lake hydraulics and the internal mixing regime that controls the rate at which the hypolimnetic $\mathrm{P}$ can reach the epilimnion. For some lakes, the morphometry substantially influences chemical and 
biological conditions. For example, shallow lakes often experience increased hypolimnetic temperatures that cause increased biological activity. These lakes may have a high sediment oxygen demand that causes anoxia, potentially followed by sediment $\mathrm{P}$ release and rapid mixing of the shallow water column.

\subsection{Internal Mixing}

Temperate lakes are generally either dimictic or polymictic (Wetzel, 2001). Dimictic lakes have two mixing events per year and thermally stratify throughout the summer and winter. Polymictic lake dynamics involve frequent or continuous mixing throughout the year. A stable hypolimnion in a consistently stratified lake allows insignificant vertical mass transfer. As such, epilimnetic oxygen does not reach the bottom and the hypolimnion may develop anoxia. However, internally released P may not reach the photic zone with a concentration significant to affect eutrophication. However, in lakes with an unstable hypolimnion, significant vertical mass transfer may occur whereby oxygen is mixed into the hypolimnion and internally released P can reach the photic zone.

Two opposing forces govern lake mixing: those supplying energy to mix and those inhibiting mixing. Mixing is attributed to destabilizing forces such as wind, cooling or warming from above or below, the temperature of maximum density $\left(4^{\circ} \mathrm{C}\right)$, inflow, outflow, and artificial destratification devices. The stabilizing force is primarily the buoyancy that is caused by density differences with depth due to temperature or salinity gradients (Robertson and Imberger, 1994; Gerten and Adrian, 2002). Minor destabilizing processes are unable to overturn a lake in a prolonged warm and calm period. Therefore, 
the hypolimnetic and epilimnetic waters remain distinct with relatively little mass transfer between the two (Robertson and Imberger, 1994). Conversely, storm events with high winds and significant precipitation can induce mixing, introducing large amounts of reduced substances (e.g., $\mathrm{Fe}(\mathrm{II})$ ) and nutrients (e.g., $\mathrm{PO}_{4}$ ) into the epilimnetic water (Effler et al., 2004). As duration of stratification increases, the ability of a lake to replenish dissolved oxygen to the hypolimnion decreases, allowing anoxic conditions to cover a greater areal extent of sediment for a longer period of time (Huttula et al., 1993; North et al., 2014). This results in intensified internal loading and stimulation of phytoplankton growth during and after vertical mixing (Wilhelm and Adrian, 2008). In such cases, an intense storm can effectively mix the lake and cause a deterioration of water quality due to nutrient upwelling.

In the last century, average regional temperature in the northeastern U.S. has increased by $2^{\circ} \mathrm{F}$ (McAvaney et al., 2001). Researchers predict recent warming is linked with alteration of thermal structures within lakes. For example, Hondzo and Stefan (1993) ran model simulations for a variety of lakes. They found that an increase in annual air temperature caused warmer surface water temperature, in small deep Minnesota lakes. However, hypolimnetic temperature decreased by as much as $3.5^{\circ} \mathrm{C}$, likely due to stratification occurring earlier in the season at lower temperatures A longer stratification period leads to more serious issues with greater oxygen depletion in the hypolimnion during late summer. In shallow lakes, rises in epilimnetic and hypolimnetic temperatures are similar in both magnitude and occurrence (Hondzo and Stefan, 1993). Therefore, hypolimnetic warming is dependent upon lake depth as well as weather variability or climate change (Jankowski et al., 2006). 
In this study, we have investigated the controls on epilimnetic total P (henceforth epilimnetic $\mathrm{P}$ or total $\mathrm{P}$ ) in 24 Maine lakes. We focused on determining the $\mathrm{P}, \mathrm{Al}$, and $\mathrm{Fe}$ concentrations in the sediments to evaluate potential for internal P release. We also quantified land use factors such as agricultural land across each watershed in order to identify vulnerable lakes. This study includes a variety of lakes; the water column data used in our analysis of vulnerability were from one specific point in time and place within each lake. Thus, parameters representing in-lake stability, hypolimnetic temperature, and epilimnetic P reflect instantaneous lake conditions, which can be used to identify cause and effect relationships between independent and dependent variables. We propose models that consider in-lake physiochemical, climate/weather, and watershed characteristics to predict epilimnetic lake $\mathrm{P}$, which allow us to evaluate and compare lake's vulnerability to eutrophication. The following analyses are used to predict critical statistical thresholds relating to vulnerability for a population of lakes. Thresholds in this study represent increased probability of eutrophication upon approach or exceedance. 


\section{CHAPTER 2: METHODS AND MATERIALS}

\subsection{Field Sites}

My study included field and laboratory components for 2015. The 2015 portion included sampling sediment and water from 24 lakes located primarily in central and southwestern Maine (Table 2.1; Appendix D; Appendix F). Land use of the 24 watersheds ranged from developed (a mix of agriculture, residences, roads, impervious surfaces, etc.) to forested. The direct watershed areas ranged from 781 to 25,213 ha, lake areas (174 to $3453 \mathrm{ha}$ ), and mean depth (4 to $23.5 \mathrm{~m}$ ).

We classified trophic range of each lake based on Wetzel's (2001) classification in which oligotrophic lakes have total $\mathrm{P}<10 \mathrm{ppb}$, mesotrophic lakes have $10<$ total $\mathrm{P}<$ $30 \mathrm{ppb}$, and eutrophic lakes have $30<$ total $\mathrm{P}<100 \mathrm{ppb}$. The 2015 lakes spanned oligotrophic to mesotrophic conditions (Table 2.1). None of the lakes were classified as eutrophic. 
Table 2.1 Selected Properties of the 2015 Lakes. Results are reported in order of increasing total epilimnetic P. Epilimnetic P, Chlorophyll a, and Secchi depth are for August 2015. Cultivated crop and hay/pasture lands are reported from 2004 (MELCD).

\begin{tabular}{|c|c|c|c|c|c|c|c|c|c|c|}
\hline Lake & Midas & $\begin{array}{l}\text { Epilimnetic } \\
\text { P, ppb }\end{array}$ & $\begin{array}{c}\mathrm{CHL} \\
\mathrm{A}\end{array}$ & $\begin{array}{l}\text { Secchi, } \\
\text { m }\end{array}$ & $\begin{array}{c}\text { Watershed } \\
\text { Area, ha }\end{array}$ & $\begin{array}{c}\text { Lake } \\
\text { Area, } \\
\text { ha }\end{array}$ & $\begin{array}{l}\text { Maximum } \\
\text { Depth, m }\end{array}$ & $\begin{array}{c}\text { Mean } \\
\text { Depth, } \\
\text { m }\end{array}$ & $\begin{array}{l}\text { Cultivated } \\
\text { Crops, ha }\end{array}$ & $\begin{array}{c}\text { Hay/Pasture, } \\
\text { ha }\end{array}$ \\
\hline Pleasant P & 224 & 1.9 & $<1$ & 15.98 & 1484 & 420 & 60.4 & 23.5 & 0 & 0 \\
\hline Tunk L & 4434 & 2.6 & 1.4 & 10.9 & 2936 & 838 & 67.7 & 21.6 & 0 & 1 \\
\hline Clearwater P & 5190 & 3.3 & 1.2 & 9.91 & 1598 & 322 & 39 & 18.3 & 0 & 15 \\
\hline Thompson L & 3444 & 3.5 & 2.1 & 10.35 & 10802 & 1788 & 36.9 & 10.7 & 65 & 504 \\
\hline Embden P & 78 & 4 & 1.6 & 9.81 & 4493 & 624 & 48.2 & 18.9 & 0 & 1 \\
\hline Square P & 3916 & 4 & 2.4 & 7.5 & 1240 & 355 & 13.4 & 6.1 & 7 & 13 \\
\hline Pleasant L & 3446 & 4.2 & 2.7 & 5.1 & 2009 & 539 & 18.9 & 8.8 & 13 & 53 \\
\hline Hopkins P & 4538 & 4.4 & 1.6 & 5.95 & 781 & 174 & 19.8 & 7.9 & 1 & 0 \\
\hline Taylor P & 3750 & 5.1 & 3.2 & 5.5 & 3772 & 264 & 13.4 & 5.2 & 32 & 371 \\
\hline Meddybemps L & 177 & 5.2 & 3.3 & 6.25 & 9867 & 2719 & 17.7 & 4.3 & 131 & 27 \\
\hline Long P & 5272 & 5.3 & 4.6 & 7.34 & 6080 & 1035 & 32.3 & 10.7 & 75 & 81 \\
\hline Mousam L & 3838 & 5.5 & 2.4 & 7.8 & 5455 & 397 & 29.9 & 5.2 & 40 & 313 \\
\hline Auburn L & 3748 & 6.1 & 2.3 & 8.67 & 3558 & 921 & 36 & 11 & 43 & 286 \\
\hline Great P & 5274 & 6.8 & 4.3 & 7.05 & 11878 & 3453 & 21 & 6.4 & 192 & 237 \\
\hline Messalonskee L & 5280 & 7.5 & 3.5 & 5.35 & 12428 & 1494 & 34.4 & 10.1 & 319 & 749 \\
\hline Damariscotta L & 5400 & 7.5 & 5.4 & 6.25 & 11496 & 1896 & 34.7 & 9.1 & 186 & 800 \\
\hline McGrath P & 5348 & 9.3 & 2.9 & 6.1 & 1136 & 189 & 8.2 & 4.9 & 23 & 7 \\
\hline Salmon L (Ellis P) & 5352 & 10.7 & 5 & 5.1 & 1077 & 281 & 17.4 & 7 & 46 & 15 \\
\hline Unity $\mathrm{P}$ & 5172 & 12.6 & 25.3 & 1.33 & 25213 & 1040 & 12.5 & 6.7 & 1310 & 2227 \\
\hline East P & 5349 & 12.6 & 3.6 & 5.34 & 1917 & 695 & 8.2 & 5.5 & 13 & 11 \\
\hline China L & 5448 & 13.9 & 17.1 & 1.8 & 8282 & 1594 & 25.9 & 8.5 & 213 & 657 \\
\hline North \& Little P & 5344 & 19 & 5.2 & 4.65 & 5543 & 1024 & 6.1 & 4 & 231 & 212 \\
\hline Sabattus P & 3796 & 19.2 & 22.1 & 1.85 & 7403 & 798 & 5.8 & 4.3 & 195 & 961 \\
\hline Webber P & 5408 & 21 & 6.4 & 2.25 & 2650 & 499 & 12.5 & 5.5 & 100 & 209 \\
\hline
\end{tabular}




\subsection{Aqueous Collection and Analysis}

Lakes in Table 2.1 were sampled in June and August 2015 at the deepest point for water samples, and sampled only in June for sediment samples. Dissolved oxygen (DO) and temperature were measured (YSI-52 probe) in 1-2 $\mathrm{m}$ increments from the surface to 1 $\mathrm{m}$ from the sediment surface. Integrated epilimnion core samples were collected using a flexible rubber sampling tube from the water surface to $1 \mathrm{~m}$ into the thermocline. Water samples from the hypolimnion were collected with a Kemmerer from $1 \mathrm{~m}$ from the sediment-water interface. Secchi disk transparency was determined on descent and ascent to determine water clarity (Tables 2.1).

Sub-samples were taken for closed-cell $\mathrm{pH}$, anions $\left(\mathrm{SO}_{4}{ }^{2-}, \mathrm{NO}_{3}{ }^{-}, \mathrm{Cl}^{-}\right)$, unfiltered total cations ( $\mathrm{Ca}, \mathrm{Mg}, \mathrm{Na}, \mathrm{K}, \mathrm{Al}$, and $\mathrm{Fe}$ ), total $\mathrm{P}$, dissolved organic carbon (DOC), and chlorophyll a. Cation samples were acidified in the field with $50 \%$ nitric acid to a $\mathrm{pH}<2$. Closed-cell pH was measured by using a TitraLab TIM860 Titration Manager. Ion chromatography (Dionex DX-500) was used to analyze the anions. Following ammonium peroxydisulfate digestion $\left(250^{\circ} \mathrm{C}, 0.5 \mathrm{~h}\right)$, total $\mathrm{P}$ was measured with a Varian Cary 50 spectrophotometer using a molybdate blue coloring reagent. A high resolution ICP-MS (Thermo Element 2) was used to measure cation concentrations. For quality control, blank, replicate, and analyte-spiked samples were run every ten field samples; the error was within 5\% for all samples.

\subsection{Sediment Collection and Analysis}

Sediment samples were obtained from each lake at two locations with a Hongve gravity corer (Hongve, 1972). The sampling locations were at the deepest point of each 
lake, and at a depth equal to one half of the deepest point. Sampling location of the half depth points were not recorded via GPS. Samples at $0-2 \mathrm{~cm}$ and $8-10 \mathrm{~cm}$ were composited from three cores collected within a $3 \mathrm{~m}$ radius, and were transferred into Whirl-pak ${ }^{\mathrm{tm}}$ bags, placed on dry ice in the dark, and transferred to the laboratory, where they were kept frozen until analysis.

The sediment 5-step sequential extraction procedure followed a modified version of Psenner et al. (1984). The first (ion-exchangeable fraction) was omitted because several studies on Maine lake sediments indicated that the typical extractable base cations (except $\mathrm{Ca}$ ), $\mathrm{Al}, \mathrm{Fe}$, and $\mathrm{P}$ in the first extraction were $<1 \%$ of the second and third extraction. We also eliminated the fifth (total residual extractable fraction). Two grams of wet sediment were sequentially extracted with $25 \mathrm{ml}$ of solution as follows: (2) $0.11 \mathrm{M}$ $\mathrm{NaHCO}_{3}$ and $0.11 \mathrm{M}$ sodium dithionite $\left(\mathrm{NaS}_{2} \mathrm{O}_{4}\right)$ at $40{ }^{\circ} \mathrm{C}$ for half an hour to extract $\mathrm{Fe}$ $\left(\mathrm{Fe}_{\mathrm{BD}}\right)$ and the associated $\mathrm{P}\left(\mathrm{P}_{\mathrm{BD}}\right)$ via the reductive dissolution of $\mathrm{Fe}(\mathrm{OH})_{3}$. (3) $1.0 \mathrm{M}$ $\mathrm{NaOH}$ at $25^{\circ} \mathrm{C}$ for $16 \mathrm{hr}$ to extract $\mathrm{Al}\left(\mathrm{Al}_{\mathrm{NaOH}}\right)$ due to the dissolution of $\mathrm{Al}(\mathrm{OH})_{3}$, and $\mathrm{P}$ $\left(\mathrm{P}_{\mathrm{NaOH}}\right)$ that is largely associated with organic matter and $\mathrm{Al}(\mathrm{OH})_{3}$. This step also leads to dissolution of some, probably slightly crystallized, $\mathrm{Fe}(\mathrm{OH})_{3}$ that was not dissolved in the previous step. (4) $0.5 \mathrm{M} \mathrm{HCl}$ at $25{ }^{\circ} \mathrm{C}$ for $16 \mathrm{hr}$ to extract $\mathrm{P}$ associated with any calcite $\left(\mathrm{CaCO}_{3}\right)$ or apatite $\left(\mathrm{Ca}_{5}\left(\mathrm{PO}_{4}\right)_{3}(\mathrm{OH}, \mathrm{Cl}, \mathrm{F})\right.$ present (Kopáček et al., 2005), as well as $\mathrm{Al}(\mathrm{OH})_{3}$ and $\mathrm{Fe}(\mathrm{OH})_{3}$ that did not dissolve in the previous two extractions. Calcite has not been observed in the sediment of any of these lakes. The extractions were conducted in $35 \mathrm{~mL}$ centrifuge tubes (Thermo Scientific ${ }^{\mathrm{TM}}$ Nalgene Polycarbonate), which were rinsed in DI water, not the reagents. Following extraction, the tubes were centrifuged at 3,000 rpm for $15 \mathrm{~min}$. Concentrations of $\mathrm{P}, \mathrm{Al}, \mathrm{Fe}$, and $\mathrm{Ca}$ were determined using 
inductively coupled plasma atomic emission spectrometry (ICP-AES; Thermo Element 2). For quality control, blank and replicate samples were run every ten field samples. A sub-sample of the homogenized sediment was dried at $100{ }^{\circ} \mathrm{C}$ to determine water weight percent, followed by combustion at $550{ }^{\circ} \mathrm{C}$ to determine the loss-on-ignition (LOI), equated to the organic matter content.

\subsection{Pre-existing Data Compilation}

The Maine Department of Environmental Protection (DEP) provided water and sediment chemistry (Appendix B) and morphometry for 106 lakes sampled from 2010 to 2012. Water samples included separate samples for total cations (Ca, Mg, Na, K, Al, Fe), anions $\left(\mathrm{Cl}^{-}, \mathrm{NO}_{3}^{-}, \mathrm{SO}_{4}{ }^{2-}\right), \mathrm{DOC}$, acid neutralization capacity (ANC), total epilimnetic (core) and hypolimnetic (1 m from bottom) P, chlorophyll a, and closed-cell $\mathrm{pH}$. Profiles of temperature and dissolved oxygen (DO), and Secchi disk transparency depth were determined for each lake. The samples were collected in August of 2010-2012. Sediment chemistry consisted of $\mathrm{Al}, \mathrm{Fe}$, and $\mathrm{P}$ concentrations in the $0-2 \mathrm{~cm}$ and $8-10 \mathrm{~cm}$ intervals, for extractions $\mathrm{BD}, \mathrm{NaOH}$, and $\mathrm{HCl}$ using the Psenner method. Sample collection, extraction, and analysis followed the same procedure mentioned in sections 2.2 and 2.3 and occurred in the same laboratory. Lake morphometry information consisted of lake elevation, flushing rate, maximum depth, average depth, watershed area, and layer area and volume at each meter by depth. 
The Lakes Environmental Association (LEA) provided data for 23 lakes sampled in August 2013 (Appendix B). These data consisted of the same parameters as the DEP lakes with the exception of water column cations, anions, or ANC metrics. Sampling and processing procedures were the same as described in sections 2.2 and 2.3 and analysis was in the same laboratory.

Average, maximum, minimum, and cumulative precipitation at each lake were obtained from Weather Underground (https://www.wunderground.com/). Data spanned two time periods, one starting January $1^{\text {st }}$ to the sampling date and the other from May $1^{\text {st }}$ to the sampling data (Appendix E). Data collected from this web site originates from the National Weather Service. Precipitation data provided the basis to assess the effect of drought or intense storms on lake water quality.

Stream Stats (https://water.usgs.gov/osw/streamstats/) from the United States Geological Survey (USGS) was used to access watershed information pertaining to each lake. Information included the percentage of storage for the combined water bodies and wetlands (from the National Wetlands Inventory) and the mean basin slope, which was computed from $10 \mathrm{~m}$ digital elevation model (DEM) from Stream Stats. (https://www.nrcs.usda.gov/wps/portal/nrcs/detail/soils/survey/).

Maine Geographical Information Systems (MEGIS; http://www.maine.gov/megis/) were accessed to acquire the land cover spatial data in each watershed (Appendix D; F). This information was collected from MELCD (Maine Land Cover Dataset; http://www.maine.gov/megis/catalog/metadata/melcd.html\#ID0EUEA), a land cover map derived from Landsat Thematic Mapper 5 and 7 from the years 1999-2000. Spatial data 
were collected with a spatial resolution of $30 \mathrm{~m}$. SPOT 5 panchromatic imagery from 2004 was used, to refine this map. The SPOT 5 imagery was collected with a spatial resolution of $5 \mathrm{~m}$. The 1999-2000 maps were refined to reflect 2004 conditions.

\subsection{Model Development}

MELCD and ArcGIS version 10.4 were utilized to construct field maps (Appendix F) and create parameters to represent human impact. These data were used to explore the ratio of land cover area relative to the lake or watershed area. We were able to identify agricultural land area in the lake watershed and create parameters such as Agricultural area: Lake Area (Ag:LA) ratio based on the direct lake watershed and the surface area of the lake. Direct watershed or sub-watershed refers to the topographic features contiguous to one lake; it does not account for chain of lake effects or the entire watershed. Agriculture lands were identified in ArcGIS by the most current land cover map for the state of Maine (MELCD; Appendix D). Other parameters such as Adjacent Agriculture: Lake Area (AdjAg:LA) ratio were quantified by including only the land cover types contiguous to the lake, or the land in close proximity to the lake. This includes land that is separated from the lake by a narrow layer of a different land type. Land cover type is variable in shape; therefore, each lake was independently evaluated to determine adjacent land cover.

To evaluate the effect of development, the road:watershed $\left(\mathrm{m}^{2}: \mathrm{m}^{2}\right)$ ratio was calculated (Appendix D), with the assumption that road density is proportional to development density and population, greater external P input. The DEP provided watershed and lake shapefiles consisting of surface area and length of roads. MEGIS 
provided a road shapefile and type (private, secondary, forestry-related, gated, etc.). The surface areas of roads in each watershed were calculated. ArcGIS from Environmental Systems Research Institute (ESRI) was used to delineate direct watersheds and clip roads to the selected watershed. Google Earth was used to measure road widths, providing the basis for the calculation of total road area.

Spatial data were examined using regression tree analysis, multiple linear regression, and quantile regression using $\mathrm{R}$ statistical software with the August epilimnetic $\mathrm{P}$ as the dependent variable. The statistical analyses allowed for an exploration of approaches to advance the understanding of lake dynamics, for example: the regression tree examined the population of lakes based on epilimnetic $\mathrm{P}$ for significant variables and relatable thresholds, while multiple linear regression equations were used to predict epilimnetic $\mathrm{P}$ values, and quantile regression was used as a development tool to relate the management of Agricultural area within the watershed to epilimnetic P. This three-tiered approach to statistical exploration allowed for the development of models to inform management in terms of sustainability solutions. Significance of each parameter in the model was based on a p-value $\leq 0.05$. Before modeling using the multiple linear and quantile regression methods, all variables were examined for normal distribution. Many variables presented positive skew, providing rationale to use $\log$ transforms. Values for the regression tree were not log transformed.

\subsubsection{Regression Tree Analysis}

A decision or regression tree was developed to identify critical statistical thresholds for predicting epilimnetic $\mathrm{P}$ through the use of a partition model. A regression 
tree explains the variation of a single response variable (epilimnetic $\mathrm{P}$ ) by one or more explanatory variables (De'ath and Fabricius, 2000). The tree performs dichotomous splits according to the relationship between the response and predictor variables by identifying groupings of predictor values that minimize residual sum of squares (RSS) within group variance (Huser et al., 2015). The recursive partitioning is repeated within each of the groups for all predictors (Quinn and Keough, 2002); the predictor variables can be used repeatedly throughout the tree, which allows the variable to be reevaluated after the previous splits have been made.

Regression tree analysis was used to develop a model able to predict a target variable value based on multiple predictor variables. Regression trees begin with the "root" (complete unsplit data) at the top, and branches down with nodes for each division and end in leaves (terminal nodes) where branches terminate (Quinn and Keough, 2002). The value listed at each split nodule represents the mean value from the response variable (Quinn and Keough, 2002); this contrasts with traditional regression, which predicts an individual value for each observational value.

A larger sample size produces a better model. A small change to the training data can cause a very different series of splits, which limits predictive performance and introduces uncertainty (Hastie et al., 2001). To combat over-fitting it is possible to 'prune' the tree to produce a generalized model. The goal is to have a balance between simplicity, in connection with the fewest nodes and explained variance in the response variable (Quinn and Keough, 2002). Cross validation was used to test error on regression tree analysis; this method involves separating the data into a calibration and validation set 
to calculate the percent of variation explained between the observed and the predicted values.

We utilized a calibration set of the 24 lakes from 2015, limiting the number of significant splits available to the partition model. We set the minsplit number, the minimum number of observations required for a split, to 5 and adjusted the complexity parameter (which determines the amount by which splitting improves the relative error) to 0.001 . Any split that did not improve the model by 0.001 was not pursued, affecting the overall model fit. A complex tree is unable to form accurate generalization from the training data set, and therefore unable to accurately predict the fit of the test set. Regression tree analysis was performed in R (R Core Team, 2015) using the package rpart (2015), version 4.1-10 (Therneau et al., 2016).

\subsubsection{Linear Regression Analysis}

Typically a regression model is used to investigate the relationships between one dependent and various independent variables. Multiple linear regressions were used to form predictive models by quantifying the strength of the relationship between response (epilimnetic P) and predictor variables. Model validation was completed to determine whether the results of statistical evaluations were capable of describing the data with certainty. The calibration set (2015, Table 2.1 and 2.2) was used to evaluate the regression relationships. The validation set (DEP + LEA, Table 2.2) was used to understand the validity of the predictive relationship. The lowest AIC indicates the best fit (Quinn and Keough, 2002). The AIC is a measure of the relative quality of a model for a set of data, and provides a means for model selection. AIC seeks a model in which the 
likelihood is maximized and number of parameters is minimized. The $\triangle \mathrm{AIC}$ of a model determines the difference between AIC of that model and the model with the lowest AIC. A $\triangle \mathrm{AIC}<2$ indicates that the models are considered equally optimal, while $\triangle \mathrm{AIC}>10$ denotes that models are significantly different (Burnham and Anderson, 2002; Brett and Benjamin, 2008). Residual sum of squares (RSS) was calculated as a measure for the amount of error remaining between the observed and predicted August epilimnetic $\mathrm{P}$ concentrations. A minimized RSS value identifies the model that explains a greater amount of the data. 
Table 2.2: Data from the Study (2015) and other organizations (DEP + LEA).

\begin{tabular}{|c|c|c|c|c|c|c|c|c|c|c|c|c|c|}
\hline Origin & $n$ & $\begin{array}{c}\text { Epilimnetic } \\
\text { P }\end{array}$ & $\mathbf{P}_{\mathbf{B D}}$ & $\mathbf{A l}_{\mathrm{NaOH}}: \mathbf{P}_{\mathrm{BD}}$ & $\mathbf{Z}_{\text {avg }}$ & Sch & Ag:WA & Ag:LA & AdjAg:WA & Rd:WA & $\mathbf{T}_{\text {hyp }}$ & DOC & $\mathbf{p H}$ \\
\hline 2015 & 24 & $\checkmark$ & $\checkmark$ & $\checkmark$ & $\checkmark$ & $\checkmark$ & $\checkmark$ & $\checkmark$ & $\checkmark$ & $\checkmark$ & $\checkmark$ & $\checkmark$ & $\checkmark$ \\
\hline DEP & 96 & $\checkmark$ & $\checkmark$ & $\checkmark$ & $\checkmark$ & $\checkmark$ & $\checkmark$ & $\checkmark$ & $\checkmark$ & $\checkmark$ & $\checkmark$ & $\checkmark$ & $\checkmark$ \\
\hline LEA & 23 & $\checkmark$ & $\checkmark$ & $\checkmark$ & $\checkmark$ & $\checkmark$ & $\checkmark$ & $\checkmark$ & $\checkmark$ & $\checkmark$ & $\checkmark$ & $X$ & $\checkmark$ \\
\hline Total & 143 & 143 & 143 & 143 & 143 & 143 & 143 & 143 & 143 & 143 & 143 & 120 & $137 *$ \\
\hline
\end{tabular}

* Indicates data missing from the DEP. 


\subsubsection{Percentile Selection Quantile Regression Analysis}

Quantile regression (QR) is a robust statistical method capable of estimating rates of change over the entire distribution of a response variable (Koenker and Bassett Jr., 1978). It is effective for datasets with unequal variation due to complex interactions among variables (Cade and Noon, 2003), specifically when not all the factors affecting the response variable can be taken into account (Xu et al., 2015). System complexity can also be illustrated by unequal variation in the dataset; meaning more than one slope is affecting the relationship between the response and predictor variables (Cade and Noon, 2003).

Using $\mathrm{QR}$, we explored the response of $\mathrm{Ag}$ :WA ratio to epilimnetic $\mathrm{P}$ across a range of quantiles. Quantiles are the points in a distribution that relate to the rank order of values in that distribution. For example: for tau $=0.80,80 \%$ of the values for the dependent variable are less than or equal to the specified function of the independent variable(s) (Cade and Noon, 2003). The basic equation for the quantile regression function is:

$$
Y^{(\tau)}=b_{0}^{(\tau)}+b_{1}^{(\tau)}(X)+\varepsilon_{i}^{(\tau)}
$$

where, $\mathrm{b}_{0}{ }^{(\tau)}$ and $\mathrm{b}_{1}{ }^{(\tau)}$ describe the intercept and slope relating the $\tau^{\text {th }}$ quantile of $\mathrm{Y}$ to $\mathrm{X}$, and $\varepsilon_{i}^{(\tau)}$ denotes the residual term for the $\tau^{\text {th }}$ quantile with an unknown distribution. For this study, $\mathrm{X}$ and $\mathrm{Y}$ represent $\mathrm{Ag}$ :WA ratio and $\log$ epilimnetic $\mathrm{P}$, respectively. 
Adopting the method of percentile selection (Xu et al., 2015) provided the basis to create subsets within the data by ranking the lake average depth $\left(Z_{\text {avg }}\right)$ and $\mathrm{Al}_{\mathrm{NaOH}}: \mathrm{P}_{\mathrm{BD}}$ ratio based on the $50^{\text {th }}$ and $75^{\text {th }}$ percentiles, and to sort the Ag:WA ratio and epilimnetic $\mathrm{P}$ accordingly. QR analysis was applied to these subsets, the distributions were fit by the $80^{\text {th }}$ quantile model. The $80^{\text {th }}$ quantile models predict epilimnetic $\mathrm{P}$ concentration threshold targets (target $=15 \mathrm{ppb})$ allowing us to predict how much $\mathrm{Ag}$ :WA ratio should be adjusted in order to maintain the threshold value of epilimnetic $\mathrm{P}$ in the system. Utilizing the $80^{\text {th }}$ percentile, allows for a more conservative approach for predicting the threshold value. QR analysis was performed in R (R Core Team, 2015) using the package quantreg (2016), version 5.26 (Koenker et al., 2016). 


\section{CHAPTER 3: RESULTS}

We hypothesized that in-lake physiochemical characteristics, climate/weather factors, and watershed characteristics control lake water quality.

\subsection{Physiochemical Characteristics}

Lake physiochemical characteristics include morphometry, sediment chemistry, and water chemistry.

\subsubsection{Morphometric Characteristics}

The relationship between lake depth and surface area were quantified using the Osgood Index (OI; Osgood, 1988):

$$
\mathrm{OI}=\frac{Z_{\text {avg }}}{A_{s}^{1 / 2}}=\frac{1}{A_{s}^{3 / 2}} \int_{0}^{z_{\max }} A(z) d z \quad \text { Eq. } 1
$$

where, $Z_{\text {avg }}$ is the area-averaged depth, $A_{s}$ is the lake surface area, $A(z)$ is the lake area at depth $z$, and $z_{\max }$ is the maximum depth. Osgood suggested that lakes with OI $>6$ develop a stable thermal stratification, whereas lakes with OI $<6$ are susceptible to summer mixing. Our results (Figure 3.1) suggest that lakes with a high OI have a low August epilimnetic $\mathrm{P}$ concentration, whereas lakes with a high epilimnetic $\mathrm{P}$ concentration have a low OI. In general, shallow lakes that have a low OI are more susceptible to mixing by wind. Therefore, internally released $\mathrm{P}$ from the sediment may reach the epilimnion at a faster rate. In deeper lakes with a high OI, internally released P from bottom sediment may not reach the epilimnion rapidly, or even until fall overturn. 


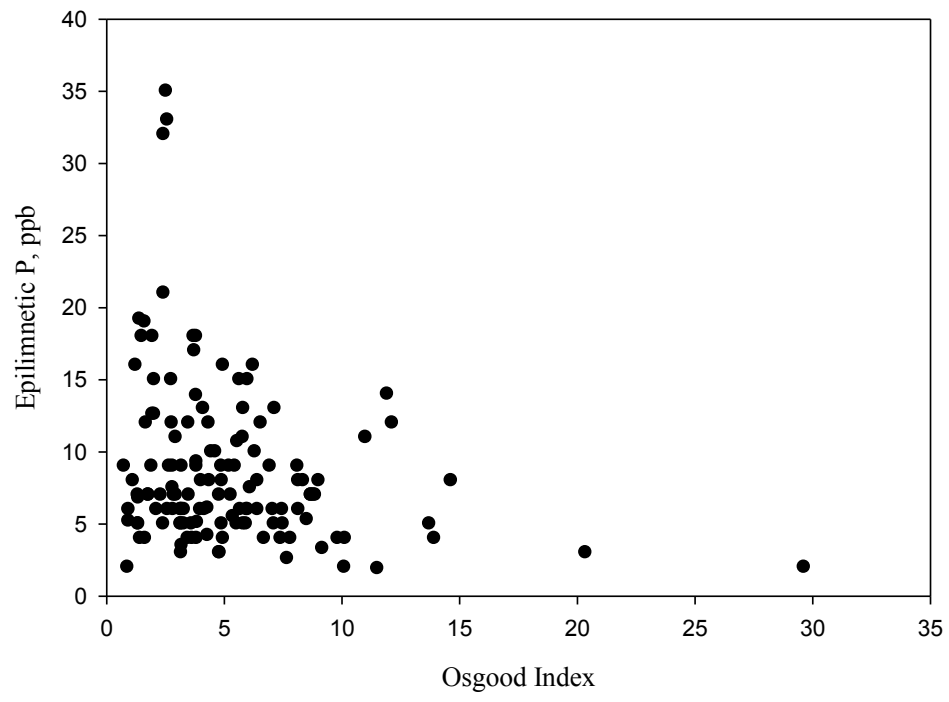

Figure 3.1: The Osgood Index (Eq. 1) versus the August epilimnetic P. Includes 143 $\left(2015+\right.$ DEP + LEA) Maine lakes. Linear regression represents an $\mathrm{R}^{2}=0.06$ and $p$-value $<0.05$.

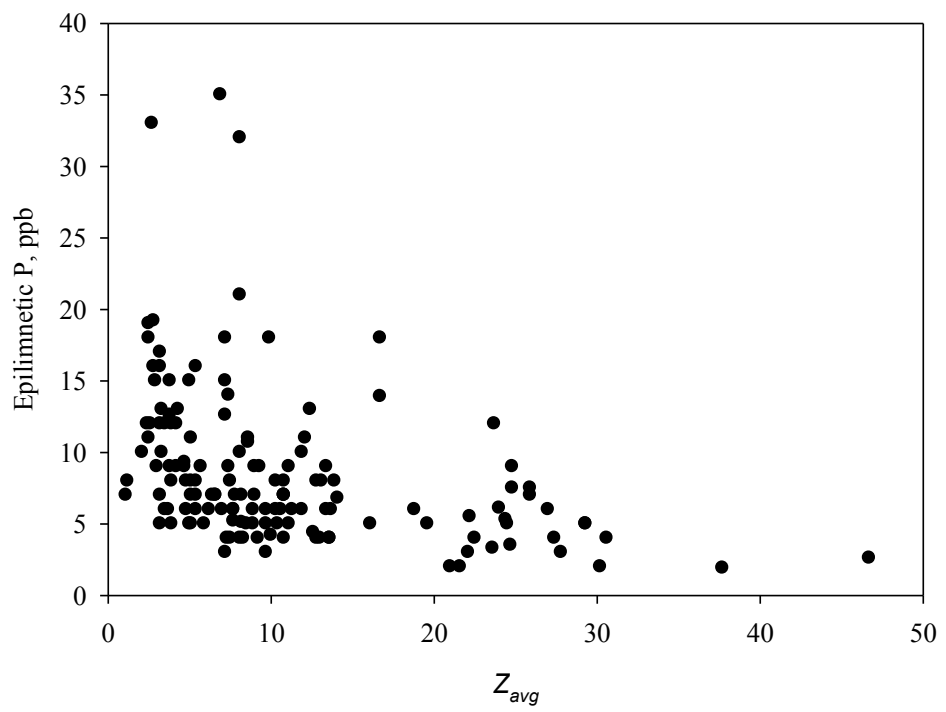

Figure 3.2: The area-averaged depth (Eq. 2) versus the August epilimnetic P. Including $143\left(2015+\right.$ DEP + LEA) Maine lakes. Linear regression represents an $\mathrm{R}^{2}=0.15$ and $\mathrm{p}$ value $<0.05$. 
The relationship between the average depth (Eq. 2) and the August epilimnetic P

is:

$$
z_{\text {avg }}=\frac{1}{A_{S}} \int_{0}^{z_{\max }} A(z) d z \quad \text { Eq. } 2
$$

(Figure 3.2). Similar to its relationship with OI, deeper lakes tend to have lower August epilimnetic $\mathrm{P}$, and all high epilimnetic $\mathrm{P}$ lakes are relatively shallow and more susceptible to having high epilimnetic $\mathrm{P}$ concentrations due to vertical mixing.

We also considered watershed area:lake area (WA:LA) ratio as a surrogate for hydraulic residence time which is a measure of the average length of time that water remains in storage. A low WA:LA ratio, for example, indicates longer residence time and higher percentage of internally loaded P. Conversely, lakes with higher WA:LA ratios are likely more driven by external P sources (Fraterrigo and Downing, 2008; Huser et al., 2015). However WA:LA was not significantly correlated to epilimnetic $P$ and did not significantly contribute to any of the analyses (Table C2, Appendix C).

\subsubsection{Surficial Sediment Fractionation}

Internal $\mathrm{P}$ loading is an important source of $\mathrm{P}$ to lakes undergoing summer anoxia. In these lakes the predominant mechanism involves the reductive dissolution of sediment $\mathrm{Fe}(\mathrm{OH})_{3}$ and the release of sediment-bound $\mathrm{P}$ from the $\mathrm{Fe}(\mathrm{OH})_{3}$ into the overlying water (Mortimer, 1941). 


\subsubsection{Sediment Phosphorus}

The total extractable sediment $\mathrm{P}$ concentration $\left(\mathrm{TP}_{\mathrm{ext}}=\mathrm{P}_{\mathrm{BD}}+\mathrm{P}_{\mathrm{NaOH}}+\mathrm{P}_{\mathrm{HCl}}\right)$ ranged from 25 to $218 \mu \mathrm{mol} \mathrm{g}^{-1}$ for the 24 (2015) lakes (Table B1, Appendix B). For the low epilimnetic P lakes (defined as August epilimnetic TP $<10 \mathrm{ppb}$ ), the largest percentage of $\mathrm{TP}_{\text {ext }}$ was in the $\mathrm{NaOH}$ fraction, ranging from 43 to $94 \%$ of $\mathrm{TP}_{\text {ext. }}$ For these lakes, the reducible $\mathrm{P}_{\mathrm{BD}}$ fraction ranged from 4 to $55 \%$ of $\mathrm{TP}_{\mathrm{ext}}$. For lakes with epilimnetic $\mathrm{TP}>10$ ppb, the sediment $\mathrm{P}_{\mathrm{NaOH}}$ and $\mathrm{P}_{\mathrm{BD}}$ fractions were 43 to $80 \%$ and 10 to $50 \%$ of $\mathrm{TP}_{\mathrm{ext}}$, respectively. The $\mathrm{P}_{\mathrm{HCl}}$ fraction remained relatively low at 4 to $13 \%$ of $\mathrm{TP}_{\text {ext. }}$ The $\mathrm{TP}_{\mathrm{ext}}$ for the set of 119 (DEP + LEA) lakes ranged from 14 to $190 \mu \mathrm{mol} \mathrm{g}^{-1}$. The largest percentage of $\mathrm{TP}_{\mathrm{ext}}$ for these lakes was in the $\mathrm{P}_{\mathrm{NaOH}}$ fraction with an average of $81 \%$.

\subsubsection{Sediment Iron}

The total extractable Fe concentration $\left(\mathrm{TFe}_{\mathrm{ext}}\right)$ ranged from 98 to $1,376 \mu \mathrm{mol} \mathrm{g}^{-1}$ for the 24 (2015) study lakes (Table B1, Appendix B). Regardless of lake productivity, most $\mathrm{TFe}_{\mathrm{ext}}$ was in the $\mathrm{BD}$ - and $\mathrm{HCl}$-extractable fractions, ranging from approximately 19 to $82 \%$ and 8 to $78 \%$, respectively. On average $87 \%$ of $\mathrm{TFe}_{\mathrm{ext}}$ consisted of BD- and HCl-extractable fractions. $\mathrm{TFe}_{\mathrm{ext}}$ for the set of 119 (DEP + LEA) lakes ranged from 54 to $1,843 \mu \mathrm{mol} \mathrm{g}^{-1}$; on average $75 \%$ consisted of $\mathrm{Fe}_{\mathrm{BD}}$ and $\mathrm{Fe}_{\mathrm{HCl}}$ fractions.

\subsubsection{Sediment Aluminum}

The total extractable Al concentration ( $\mathrm{TAl}_{\text {ext }}$ ) ranged from 232 to $713 \mu \mathrm{mol} \mathrm{g}^{-1}$ for the 24 (2015) study lakes (Table B1, Appendix B). Regardless of lake productivity level, $98 \%$ of $\mathrm{TAl}_{\mathrm{ext}}$ was in the $\mathrm{Al}_{\mathrm{NaOH}}$ and $\mathrm{Al}_{\mathrm{HCl}}$ fractions, which ranged from 
approximately 23 to $72 \%$ and 14 to $77 \%$, respectively. The surficial sediment in Mousam Lake contained a high $\mathrm{Al}_{\mathrm{BD}}$ fraction at $27 \%$ of $\mathrm{TAl}_{\mathrm{ext}}$. The $\mathrm{TAl}_{\mathrm{ext}}$ for the $119(\mathrm{DEP}+$ LEA) lake set ranged from 188 to $1026 \mu \mathrm{mol} \mathrm{g}$; on average $\mathrm{Al}_{\mathrm{NaOH}}$ plus $\mathrm{Al}_{\mathrm{HCl}}$ fractions comprised $99 \%$ of extractable Al.

\subsubsection{The $\mathrm{Al}_{\mathrm{NaOH}}: \mathrm{Fe}_{\mathrm{BD}}$ and $\mathrm{Al}_{\mathrm{NaOH}}: \mathrm{P}_{\mathrm{BD}}$ Ratios}

Previous work has shown that sediment molar $\mathrm{Al}_{\mathrm{NaOH}} \mathrm{Fe}_{\mathrm{BD}}$ and $\mathrm{Al}_{\mathrm{NaOH}}: \mathrm{P}_{\mathrm{BD}}$ ratios predict the mobilization potential of sediment P (Kopáček et al., 2005; Lake et al., 2007). These ratios are plotted against the epilimnetic P (Figures 3.3 and 3.4), and hypolimnetic $\mathrm{P}$ (Figures 3.5 and 3.6). Those studies showed that lakes with $\mathrm{Al}_{\mathrm{NaOH}}: \mathrm{Fe}_{\mathrm{BD}}$ ratios $>3$ or $A l_{\mathrm{NaOH}}: \mathrm{P}_{\mathrm{BD}}$ ratios $>25$ release low $\mathrm{P}$ concentrations during anoxia. For the 24 (2015) study lakes, the $\mathrm{Al}_{\mathrm{NaOH}}: \mathrm{Fe}_{\mathrm{BD}}$ and $\mathrm{Al}_{\mathrm{NaOH}}: \mathrm{P}_{\mathrm{BD}}$ ratios ranged from 0.2 to 5.2 and 2.4 to 214.8, respectively (Appendix C). All (2015 + DEP + LEA) lakes with $\mathrm{Al}_{\mathrm{NaOH}}: \mathrm{Fe}_{\mathrm{BD}}$ ratios $>3$ had lower epilimnetic $\mathrm{P}$ concentrations (Figure 3.3) and low hypolimnetic $\mathrm{P}$ concentrations (Figure 3.5).

Among the 24 (2015) study lakes, only Pleasant (Caratunk) and Hopkins had $\mathrm{Al}_{\mathrm{NaOH}}: \mathrm{Fe}_{\mathrm{BD}}$ ratios $>3$, corresponding to lakes with a low epilimnetic P concentrations; the sediment in the remaining 22 lakes did not exceed this ratio (Appendix C). The majority of lakes with relatively high epilimnetic P concentrations ( $>15 \mathrm{ppb})$ had relatively low $\mathrm{Al}_{\mathrm{NaOH}}: \mathrm{P}_{\mathrm{BD}}$ ratios, although some had $\mathrm{Al}_{\mathrm{NaOH}}: \mathrm{P}_{\mathrm{BD}}$ ratios $>25$ (Figure 3.4), illustrating that individual ratios may not predict epilimnetic P perfectly. For example, among the 24 (2015) study lakes: Square, Mousam, Auburn, and Messalonskee had $A l_{\mathrm{NaOH}}: \mathrm{P}_{\mathrm{BD}}$ ratios $<25$ but low epilimnetic $\mathrm{P}$ concentrations. These lakes had unfavorable 
sediment geochemistry indicating that the lakes were capable of significant P release; however, low epilimnetic P concentrations were observed. Therefore, other factors such as $Z_{\text {avg }}$, Sch, WA:LA ratio, and Ag:WA ratio, among others, play a role in keeping these lakes from releasing internally loaded $\mathrm{P}$ into the epilimnetic water. For example Lake Auburn had a Sch of $867 \mathrm{~J} / \mathrm{m}^{2}$ on the sampling day, indicating a stratified lake. Conversely, North Pond had a high epilimnetic $\mathrm{P}$ concentration with an $\mathrm{Al}_{\mathrm{NaOH}}: \mathrm{P}_{\mathrm{BD}}$ ratio $>25$; North Pond does not act as anticipated because it is shallow and on the day of sampling had a $S c h$ of $5 \mathrm{~J} / \mathrm{m}^{2}$. North Pond is likely affected by external P inputs because $8.0 \%$ of the watershed is comprised of agricultural lands. All (2015 + DEP + LEA) lakes with a low hypolimnetic $\mathrm{P}$ had $\mathrm{Al}_{\mathrm{NaOH}}: \mathrm{P}_{\mathrm{BD}}>25$ (Figure 3.6), consistent with the model proposed by Kopáček et al. (2005). 


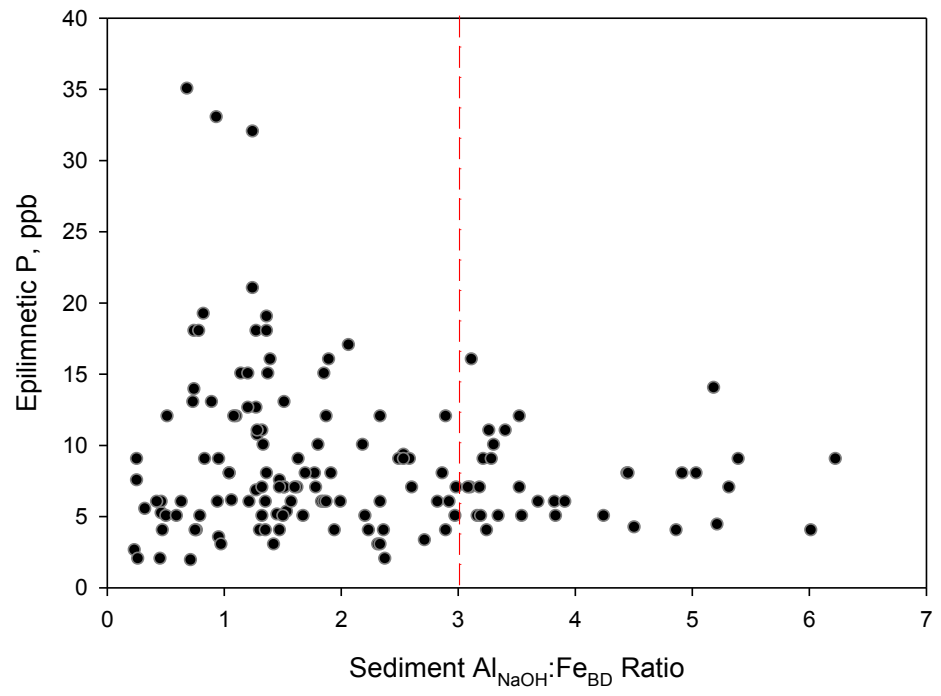

Figure 3.3: Sediment $\mathrm{Al}_{\mathrm{NaOH}}: \mathrm{Fe}_{\mathrm{BD}}$ versus Epilimnetic P. Including 143 (2015 + DEP + LEA) Maine lakes.

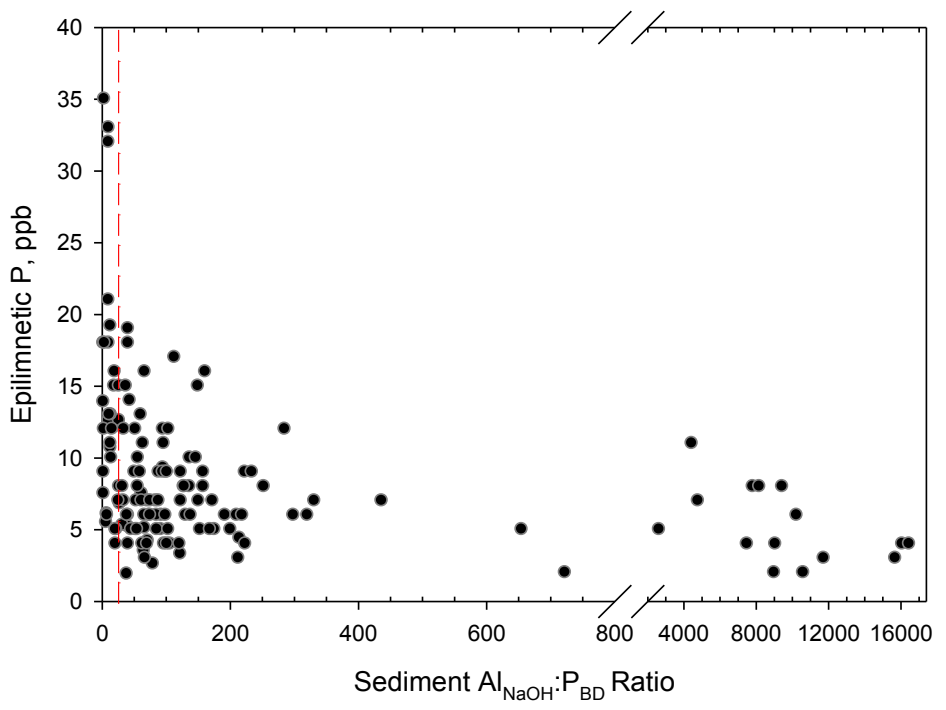

Figure 3.4: Sediment $\mathrm{Al}_{\mathrm{NaOH}}: \mathrm{P}_{\mathrm{BD}}$ ratio versus epilimnetic P. Including $143(2015+\mathrm{DEP}$ + LEA) Maine lakes. 


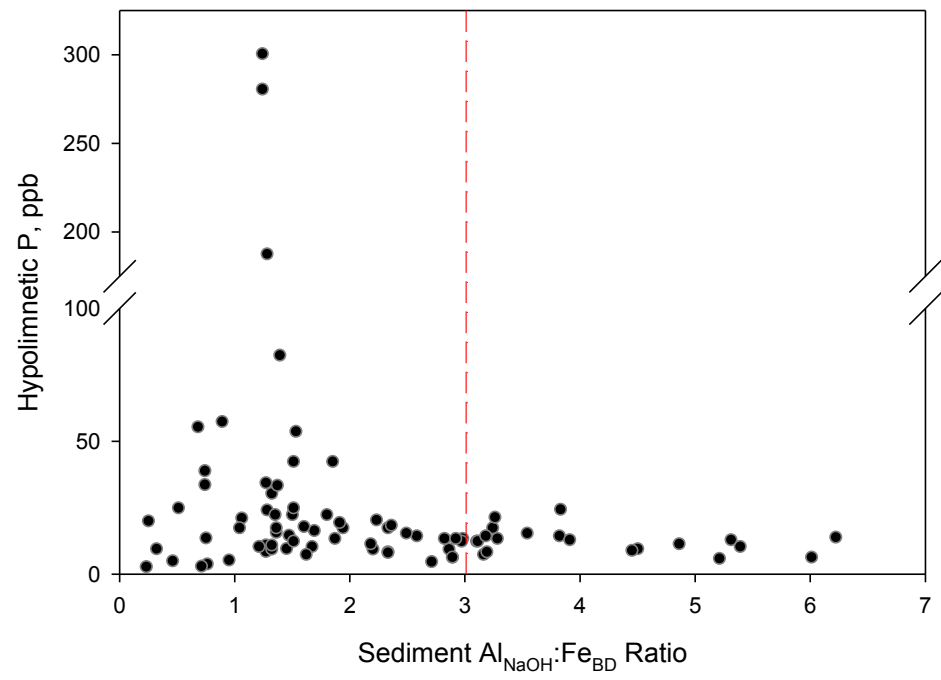

Figure 3.5: Sediment $A l_{\mathrm{NaOH}}: \mathrm{Fe}_{\mathrm{BD}}$ ratio versus Hypolimnetic P. Including 84 (2015+ DEP + LEA) Maine lakes.

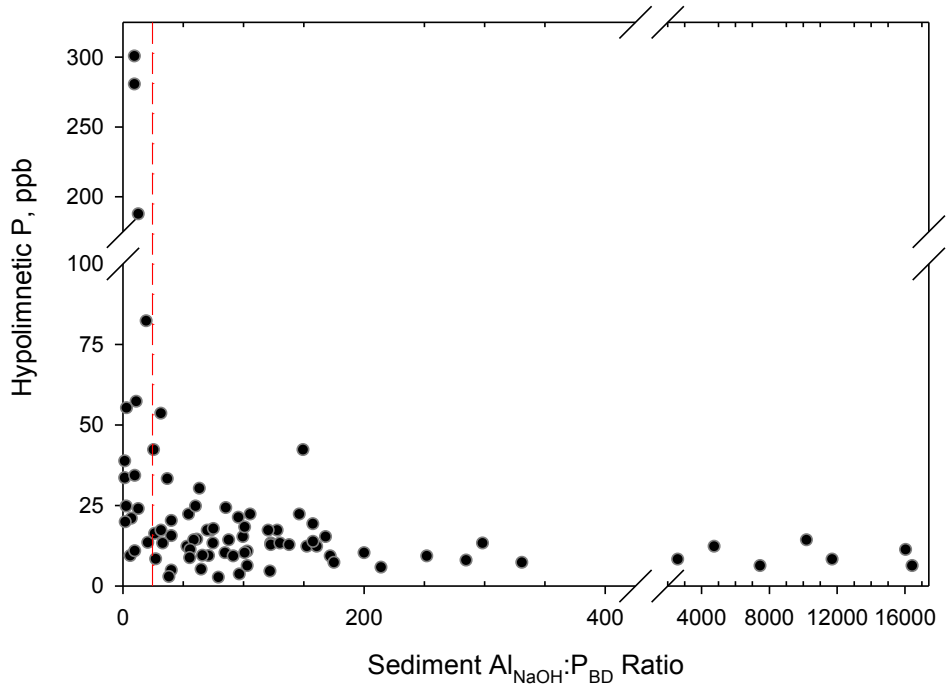

Figure 3.6: Sediment $\mathrm{Al}_{\mathrm{NaOH}}: \mathrm{P}_{\mathrm{BD}}$ ratio versus Hypolimnetic P. Including 84 (2015 + DEP + LEA) Maine lakes. 


\subsubsection{Water Chemistry}

Statistical modeling suggests that among the aqueous species, lake DOC concentration and $\mathrm{pH}$ are the most important predictors for the August epilimnetic $\mathrm{P}$ concentrations (section 3.4). In recent decades, DOC concentrations have been increasing in surface waters of Europe and North America (Monteith et al., 2007). DOC is projected to continue increasing due to recovery from soil acidification and may be rebounding to levels typical of pre-industrial times (Monteith et al., 2007). DOC influence on the lake ecosystem is complex and not fully understood (Solomon et al., 2015). Increasing DOC attenuates light, decreasing the epilimnetic depth, and enhancing stratification (Solomon et al., 2015). Homyak et al. (2014) hypothesized that DOC may act as a transport mechanism for nutrients including P. DOC concentration in lakes is a result of watershed land cover type and water retention time in the lake (Gergel et al., 1999). Higher concentrations are generally due to the presence of wetlands.

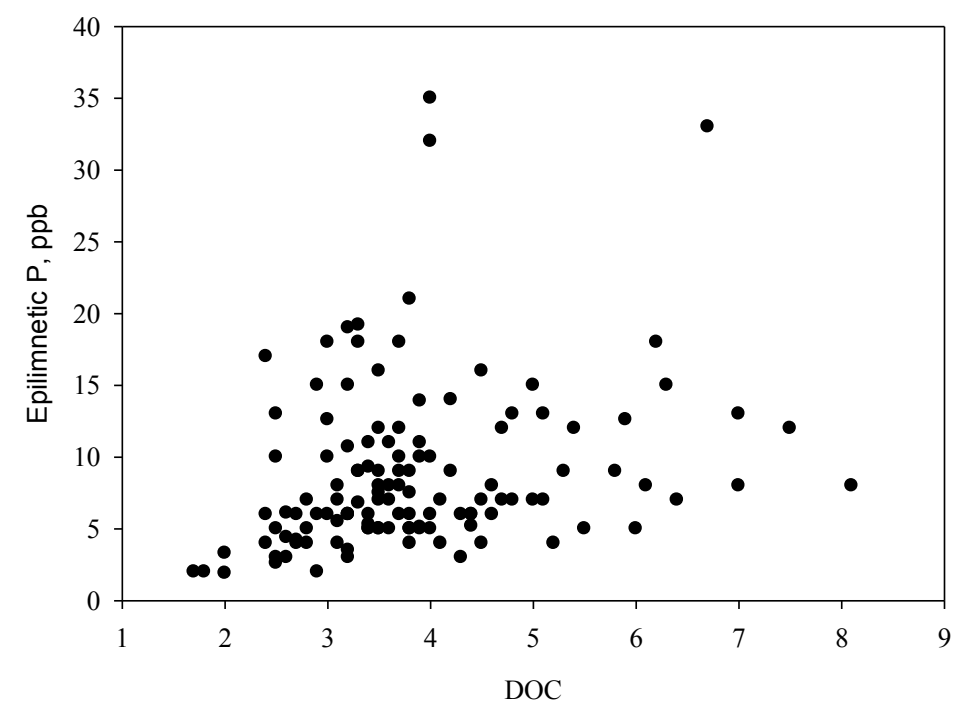

Figure 3.7: The DOC versus Epilimnetic P. Including 120 (2015 + DEP) Maine lakes. Linear fit provided an $\mathrm{R}^{2}=0.086$ and $\mathrm{p}$-value $<0.05$. 
There is no relationship between lake DOC and epilimnetic P (Figure 3.7). For the 24 (2015) study lakes, DOC concentrations in the epilimnion ranged from 2.0 to 5.9 $\mathrm{mg} / \mathrm{L}$, similar to their concentrations in the hypolimnion that ranged from 1.9 to 5.8 $\mathrm{mg} / \mathrm{L}$. In the remaining lakes (DEP) epilimnetic DOC ranged from 1.7 to $8.1 \mathrm{mg} / \mathrm{L}$ (Appendix C).

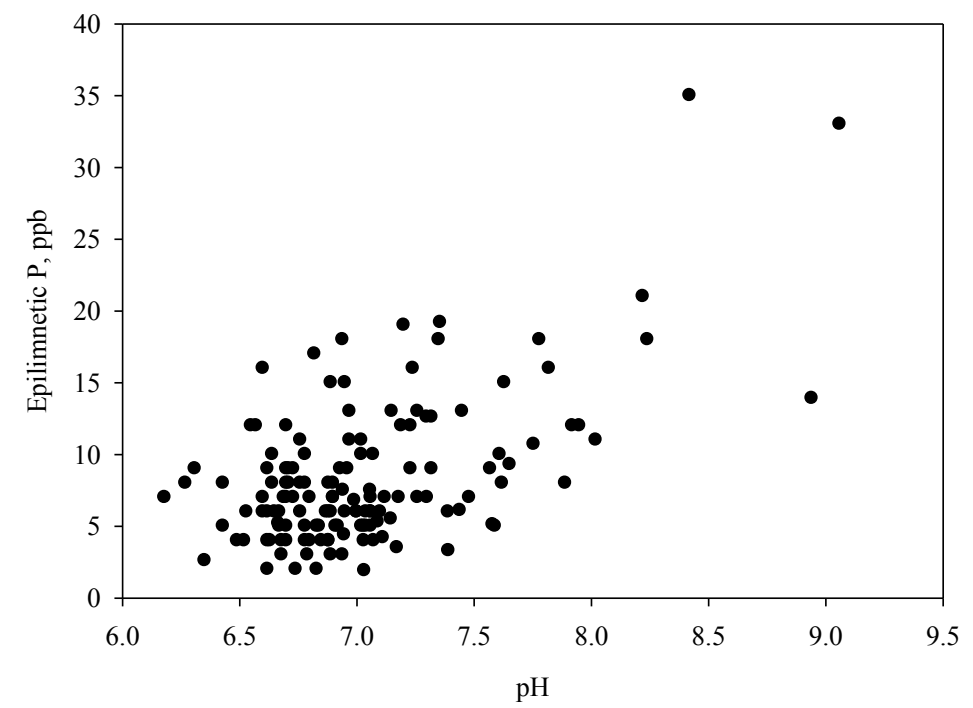

Figure 3.8: Epilimnetic pH versus Epilimnetic P. Including 137 (2015 + DEP + LEA) Maine lakes. Linear fit provided an $\mathrm{R}^{2}=0.330$ and $\mathrm{p}$-value $<0.05$.

In this study, the relationship between epilimnetic $\mathrm{pH}$ and $\mathrm{P}$ is weak, but significant and positive (Figure 3.8). For the 24 (2015) lakes, $\mathrm{pH}$ ranged from 6.4 to 8.9 and hypolimnetic $\mathrm{pH}$ ranged from 5.8 to 7.1. The remaining lakes (DEP + LEA) had epilimnetic $\mathrm{pH}$ ranging from 6.2 to 9.1 , epilimnetic $\mathrm{P}$ ranging from 2 to $35 \mathrm{ppb}$, and hypolimnetic P ranging from 6 to 300 ppb (Appendix C). 


\subsection{Climate Factors}

Climate/weather factors include hypolimnetic water temperature, wind intensity, and precipitation, all of which potentially influence lake water quality. These factors in conjunction with the lake morphometric properties control lake thermal stratification. Water temperature can affect the lake water quality in two ways:

(1) Warmer waters lead to higher levels of microbial activity that increase the sediment oxygen demand and may result in the onset of anoxia, especially in bottom waters. A warm hypolimnion can bring about a rapid depletion of dissolved oxygen if there is enough primary production to exceed the oxygen available, and subsequently release $\mathrm{P}$ and redox-sensitive species such as $\mathrm{Fe}(\mathrm{II})$ and $\mathrm{Mn}(\mathrm{II})$, from sediment. In lakes with warm bottom waters that are not thermally stable, upward mixing of P-rich waters is readily facilitated by wind. Our results show a weak but positive correlation between hypolimnetic temperature and August epilimnetic P (Figure 3.9).

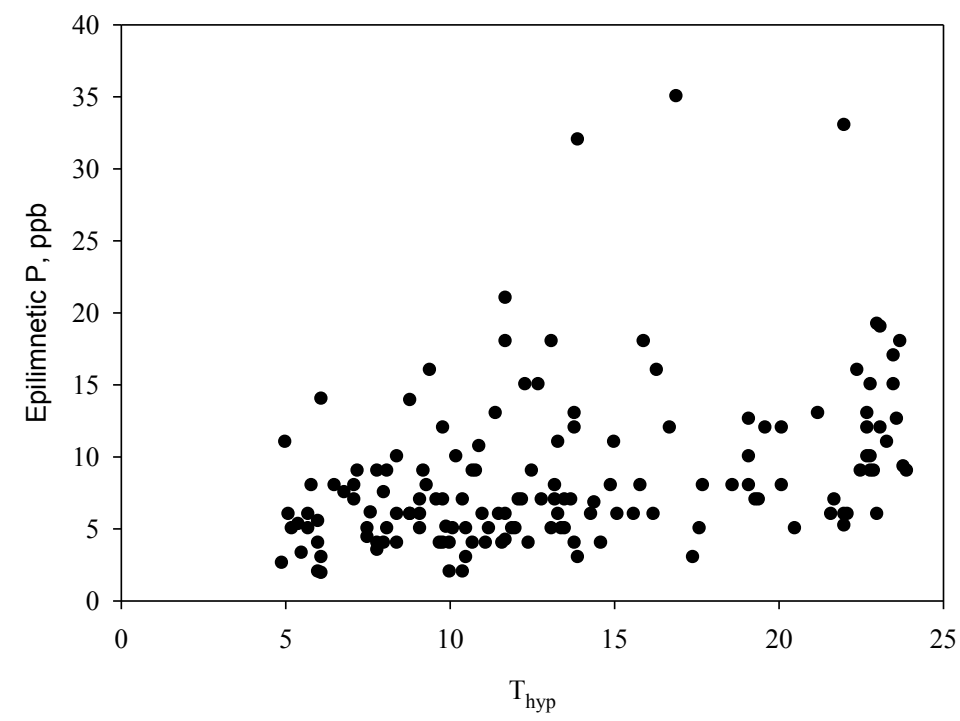

Figure 3.9: Hypolimnetic Temperature versus Epilimnetic P. Including 143 (2015 + DEP + LEA) Maine lakes. Linear fit provided an $\mathrm{R}^{2}=0.15$ and $\mathrm{p}$-value $<0.05$. 
(2) The vertical temperature distribution of a lake affects its thermal stability. Thermally stable lakes are characterized by cooler hypolimnia overlain by warmer epilimnia. In such lakes, the density difference between the two layers may cause sufficient buoyancy to counteract the destabilizing shear forces created by wind. Thermal stability is subject to change throughout the season depending on the climate and weather factors, such as storm intensity along with air and water temperature. The Schmidt stability (Sch) characterizes the thermal stability of a lake (Schmidt, 1928). Sch is the energy required to mix a unit lake surface area (e.g., $\mathrm{J} / \mathrm{m}^{2}$ ), and is calculated by integrating the lake surface area at different depths and the vertical temperature distribution:

$$
S c h=\frac{g}{A_{s}} \int_{0}^{z_{\max }}\left(z-z_{v}\right) \rho(z) A(z) d z
$$

In Eq. 3, $g$ is the acceleration of gravity, $\rho(z)$ is the density of the water at depth $z$, and $z_{v}$ is the depth to the center of volume of the lake (Read and Muraoka, 2011),

$$
\mathrm{z}_{v}=\frac{\int_{0}^{z_{\max }} z A(z) d z}{\int_{0}^{z_{\max }} A(z) d z}
$$

Schmidt stability does not explicitly account for wind velocity, even though the destabilizing effect of wind is implicitly included in the homogenization of the density gradient (Robertson and Imberger, 1994). A strong thermal stability has a high Sch value. Therefore, lakes with a high $S c h$ are less susceptible to physical mixing than lakes with a low $S c h$. In general, shallow lakes possess a low Sch. In theory, Sch in dimictic lakes approaches zero during the fall and spring turnovers, when the water column mixes 
completely. Sch increases after the spring turnover and reach its maximum during the late summer. In fall, as the epilimnion gradually cools, Sch decreases to a minimum.

Our results show that lakes with $S c h>600 \mathrm{~J} / \mathrm{m}^{2}$ in August have a low August epilimnetic $\mathrm{P}$, suggesting that $\mathrm{P}$-rich bottom waters migrate at a slower rate to the top in thermally stable lakes, and all high August epilimnetic P lakes have a lower Sch (Figure $3.10)$.

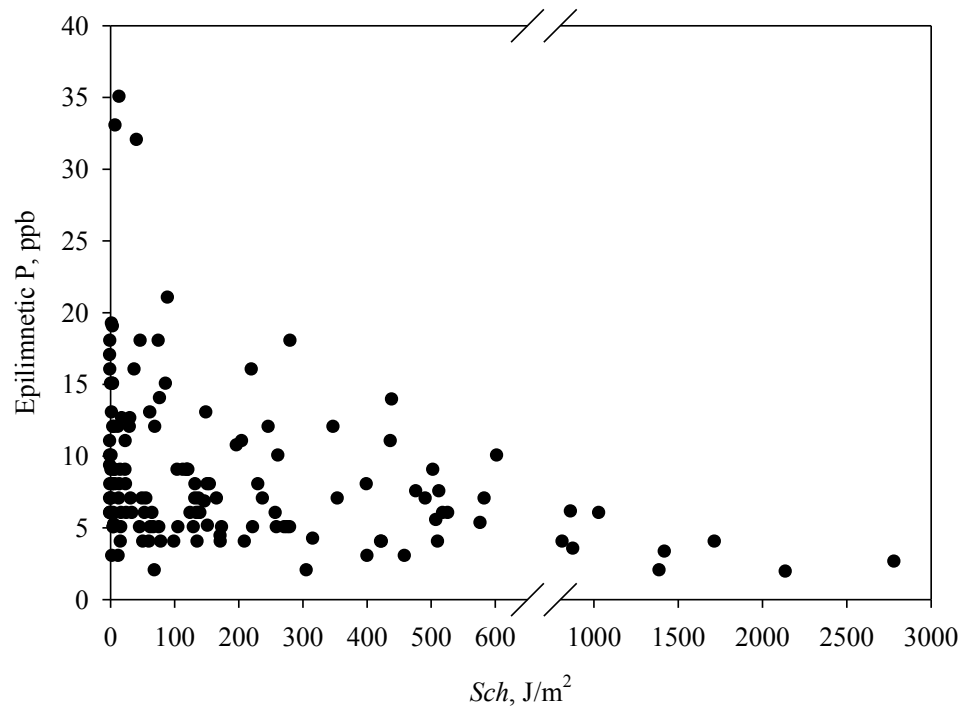

Figure 3.10: Schmidt Stability versus Epilimnetic P. Including 143 (2015 + DEP + LEA) Maine lakes.

(3) Increased precipitation may lead to increased P export from the watershed (Roy et al., 1999) and lake mixing may be enhanced if precipitation is substantial and associated with wind (Effler et al., 2004). To capture the effect of precipitation on lake water quality, we assessed the impact of cumulative rainfall data for a given year prior to the day (in August) of sampling in the MLR models. Precipitation parameters were not significantly correlated to epilimnetic $\mathrm{P}$ and did not significantly contribute to any of the models (Table C2, Appendix C). 


\subsection{Watershed Characteristics}

Phosphorus exported from the watershed via surface runoff is an important external pollution source for the lake (Wetzel, 2001), making watershed hydrologic and land-use characteristics important parameters. Agriculture and other watershed land disturbances enhance dissolved and particulate $\mathrm{P}$ in surface runoff. Impermeable surfaces such as roads increase surface runoff. Conversely, wetlands and forests generally sequester $\mathrm{P}$.

We hypothesized that agricuture is the most important watershed contributor to lake water quality. The effect of agriculture was assessed by calculating the hay/pasture and cultivated crop land area in watersheds and dividing by the watershed or lake area to obtain agricultural land:watershed area ratio (Ag:WA) and agricultural land:lake area ratio (Ag:LA). We also considered the contribution of the agricultural land adjacent to the lake to obtain the adjacent agricultural land:watershed area ratio (AdjAg:LA). Our results showed a weak but significant relationship between the Ag:WA ratio and August epilimntic P concentrations (Figure 3.11). The effects of other landuse measures, such as urban development and road coverage, were considered, but did not contribute significantly to lake water quality (section 3.4). 


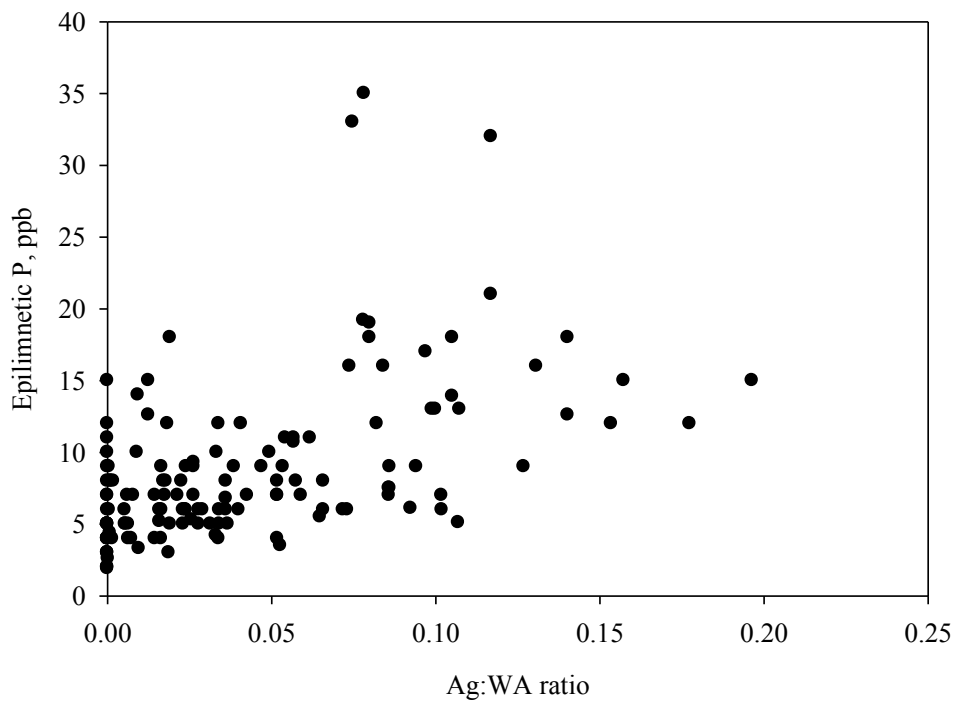

Figure 3.11: Ag:WA ratio versus Epilimnetic P. Including 143 (2015 + DEP + LEA) Maine lakes. Linear fit provided an $\mathrm{R}^{2}=0.27$ and $\mathrm{p}$-value $<0.05$.

\subsection{Statistical Modeling Results}

\subsubsection{Regression Tree}

To determine the predictors of the August epilimnetic $\mathrm{P}$ concentrations, a decision tree was developed from the set of 24 (2015) study lakes (Figure 3.12). Independent variables for the epilimnetic $\mathrm{P}$ included physiochemical characteristics such as $\mathrm{Al}_{\mathrm{NaOH}}: \mathrm{P}_{\mathrm{BD}}, \mathrm{P}_{\mathrm{BD}}, \mathrm{Al}_{\mathrm{NaOH}}: \mathrm{Fe}_{\mathrm{BD}}, \mathrm{OI}, \mathrm{WA}: \mathrm{LA}, \mathrm{pH}$, and DOC; climate characteristics included hypolimnetic temperature $\left(\mathrm{T}_{\mathrm{hyp}}\right)$, precipitation, and $S c h$; and watershed characteristics included Road:WA, Ag:WA, AdjAg:LA, and Ag:LA ratios. The data set for the 119 (DEP + LEA) lakes was used for model validation.

The average August epilimnetic P concentration for the 24 (2015) lakes was 8.1 ppb. The first threshold was $S c h$ at $95 \mathrm{~J} / \mathrm{m}^{2}$, below which lakes had an average P concentration of $14.0 \mathrm{ppb}$. These lakes were more susceptible to internal mixing of hypolimnetic P-rich water; 29\% of the 24 (2015) study lakes and 54\% of the validation 
$\left(\right.$ DEP + LEA) lakes were in this category. For lakes with $S c h<95 \mathrm{~J} / \mathrm{m}^{2}$, the first threshold was the AdjAg:LA ratio $=0.066$; lakes above this ratio had the highest average $\mathrm{P}$ concentration of $20 \mathrm{ppb}$ in this study.

Lakes with $S c h \geq 95 \mathrm{~J} / \mathrm{m}^{2}$ had lower average P concentration of $5.7 \mathrm{ppb} ; 71 \%$ of the 24 (2015) study lakes and $46 \%$ of the validation lakes were in this category. For this group of lakes, the next threshold was a $\mathrm{pH}=7.7$ with an average epilimnetic $\mathrm{P}$ concentration of $4.8 \mathrm{ppb}$. Lakes with $\mathrm{pH}<7.7$ were all oligotrophic with an average epilimnetic $\mathrm{P}$ concentration $<7.3 \mathrm{ppb}$; further splits for these low-epilimnetic P lakes were provided by $S c h, \mathrm{Ag}: \mathrm{WA}$ ratio, $Z_{\text {avg }}$, and $\mathrm{pH}$. 


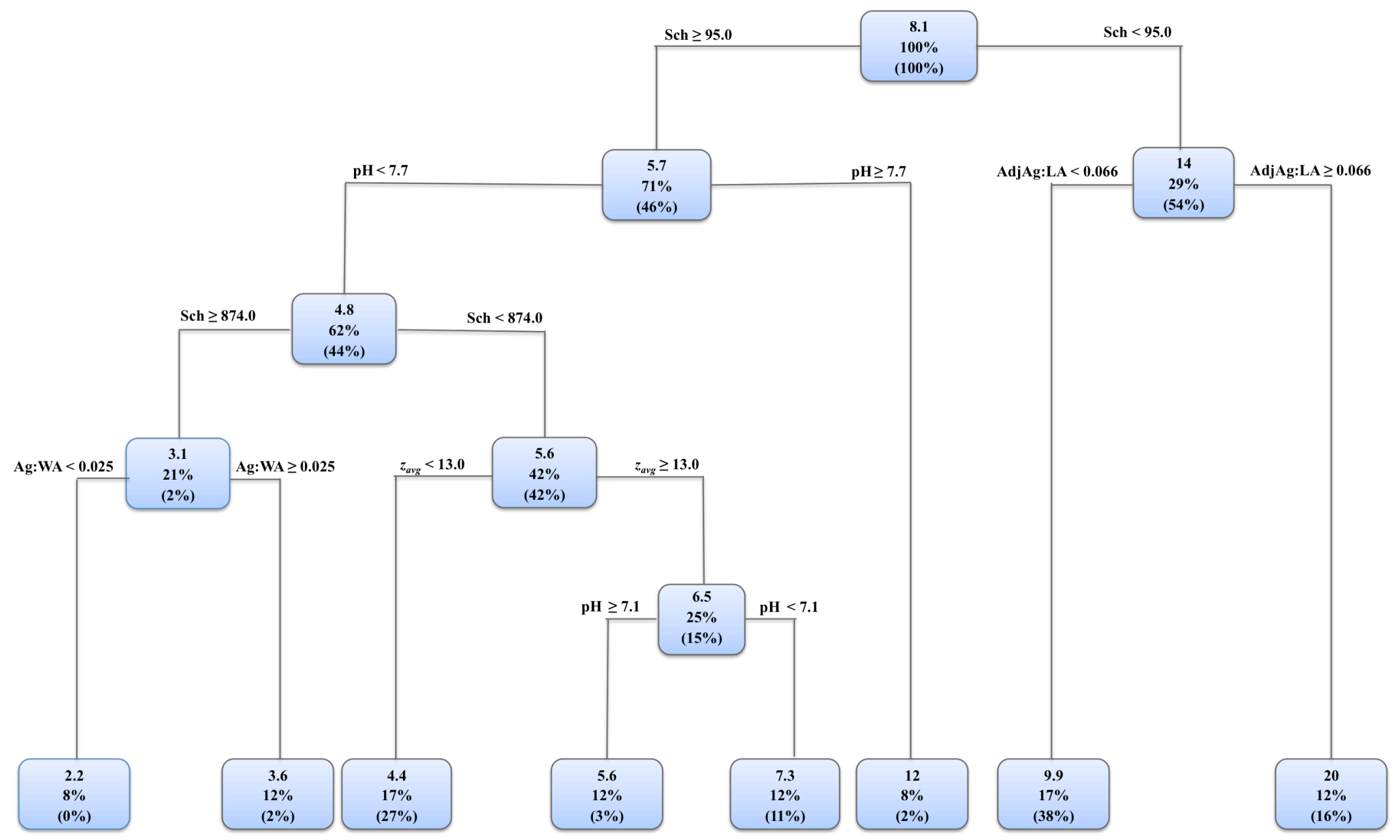

Figure 3.12: Regression Tree Analysis for Epilimnetic P. Regression threshold values for the mean August epilimnetic P concentration (top figure in each box, $\mu \mathrm{g} / \mathrm{L}$ ). Percentages are those of 24 (2015) lakes within each category; percentages in parentheses are those for the 119 (DEP + LEA) lakes. At each split, we continue to the left side of the branch determined by the ' $<$ ' or ' $>$ ' sign. 


\subsubsection{Multiple Linear Regression}

Multiple linear regression (MLR) models were developed for the set of 24 (2015) study lakes. Out of the entire set of the predictor variables (Appendix C), lake August epilimnetic $\mathrm{P}$ concentrations were best predicted by different combinations of physiochemical parameters (i.e., $\mathrm{Al}_{\mathrm{NaOH}}: \mathrm{P}_{\mathrm{BD}}, \mathrm{P}_{\mathrm{BD}}, \mathrm{DOC}, \mathrm{pH}$, and $Z_{\text {avg }}$ ); climate factors (i.e., Sch, hypolimnetic temperature); and watershed characteristics (i.e., Rd:WA, Ag:WA, AdjAg:LA, and Ag:LA ratios).

Table 3.1 shows the MLR models with $\mathrm{R}^{2}>0.70$. The performance of the three highest correlated models determined by the Akaike Information Criterion ( $\triangle \mathrm{AIC})$ is shown in Figure 3.13. The top two models are distinguished by the change in the Akaike Information Criterion $(\triangle \mathrm{AIC})<2$, suggesting that these models are equally optimal (Burnham and Anderson, 2002).

$\mathrm{P}_{\mathrm{BD}}, \mathrm{Adj} \mathrm{Ag}: \mathrm{LA}$ ratio and lake $Z_{\text {avg }}$ are common in the three highest correlated models, suggesting the importance of sediment chemistry, land use, and lake morphology in controlling the epilimnetic P concentrations. Models 1 and 3 also include DOC and the $\mathrm{Al}: \mathrm{P}$, respectively, as predictor variables. Combinations of these and other parameters in the three categories of physicochemical, watershed, and climate factors appear in all models.

We applied the MLR models to the set of 119 (DEP + LEA) lakes in order to validate the models (Table 3.1). DOC concentrations were not available for 23 lakes; thus, when DOC concentration was used as a predictor variable, data from only 96 lakes were used. The residual sum-of-squares (RSS), also known as the error sum-of-squares, was calculated as a measure for the deviation between the observed and predicted August 
epilimnetic P concentrations. Models 1, 3, and 9 (Figure 3.14) had the lowest RSS values ranging between 3.84 and 3.90 (Table 3.1). These models use $\log \mathrm{P}_{\mathrm{BD}}, \log \mathrm{Al}: \mathrm{P}, \log Z_{\text {avg, }}$, AdjAg:LA ratio, and DOC as the predictors. 
Table 3.1 Multiple Linear Regression Equation Results from the 2015 Study Lakes. Variables include log $\mathrm{P}_{\mathrm{BD}}, \log \mathrm{Al}: \mathrm{P}, \log$ Sch, $\log$ Average Depth $\left(Z_{\text {avg }}\right)$, hypolimnetic temperature $\left(T_{\text {hyp }}\right)$, Adjacent Ag:Lake Area (AdjAg:LA) ratio, Ag:Watershed Area (Ag:WA) ratio, Ag:Lake Area (Ag:LA) ratio, Road:Watershed Area ratio (Rd:WA), pH, and DOC.

\begin{tabular}{|c|c|c|c|c|c|c|}
\hline & \multirow[b]{2}{*}{ Model } & \multicolumn{3}{|c|}{ Calibration } & \multicolumn{2}{|c|}{ Validation } \\
\hline & & $\mathbf{R}^{2}$ & AIC & $\Delta \mathrm{AIC}$ & $\mathbf{R S S}^{1}$ & $n^{2}$ \\
\hline 1 & $\mathrm{P}_{\mathrm{BD}}+Z_{\text {avg }}+\operatorname{Adj} \mathrm{Ag}: \mathrm{LA}+\mathrm{DOC}$ & 0.844 & -26.04 & 0.00 & 3.84 & 96 \\
\hline 2 & $\mathrm{P}_{\mathrm{BD}}+Z_{\text {avg }}+\operatorname{Adj} \mathrm{Ag}: \mathrm{LA}$ & 0.823 & -25.08 & 0.96 & 4.92 & 119 \\
\hline 3 & $\mathrm{Al}: \mathrm{P}+Z_{a v g}+\operatorname{AdjAg}: \mathrm{LA}+\mathrm{DOC}$ & 0.826 & -23.47 & 2.57 & 3.89 & 96 \\
\hline 4 & $\mathrm{P}_{\mathrm{BD}}+Z_{\text {avg }}+\operatorname{AdjAg}: \mathrm{LA}+\mathrm{pH}$ & 0.825 & -23.26 & 2.77 & 4.05 & 113 \\
\hline 5 & $\mathrm{Al}: \mathrm{P}+Z_{\text {avg }}+\operatorname{Adj} \mathrm{Ag}: \mathrm{LA}$ & 0.805 & -22.69 & 3.34 & 4.87 & 119 \\
\hline 6 & $\mathrm{P}_{\mathrm{BD}}+Z_{\text {avg }}+\mathrm{Ag}: \mathrm{WA}$ & 0.804 & -22.63 & 3.41 & 4.13 & 119 \\
\hline 7 & $\mathrm{P}_{\mathrm{BD}}+Z_{\text {avg }}+\mathrm{Rd}: \mathrm{WA}$ & 0.802 & -22.41 & 3.63 & 9.19 & 119 \\
\hline 8 & $\mathrm{P}_{\mathrm{BD}}+\operatorname{Adj} \mathrm{Ag}: \mathrm{LA}+\mathrm{T}_{\mathrm{hyp}}$ & 0.788 & -20.79 & 5.24 & 5.88 & 119 \\
\hline 9 & $\mathrm{Al}: \mathrm{P}+Z_{\text {avg }}+\mathrm{Ag}: \mathrm{WA}$ & 0.780 & -19.89 & 6.15 & 3.90 & 119 \\
\hline 10 & $\mathrm{P}_{\mathrm{BD}}+Z_{a v g}+\mathrm{Ag}: \mathrm{LA}$ & 0.755 & -17.29 & 8.75 & 5.22 & 119 \\
\hline 11 & Al:P+ AdjAg:LA $+T_{\text {hyp }}$ & 0.755 & -17.25 & 8.79 & 6.19 & 119 \\
\hline 12 & $\mathrm{Al}: \mathrm{P}+S c h+\operatorname{Adj} A g: \mathrm{LA}$ & 0.741 & -15.98 & 10.06 & 5.99 & 119 \\
\hline 13 & $\mathrm{P}_{\mathrm{BD}}+S c h+\operatorname{Adj} A g: \mathrm{LA}$ & 0.740 & -15.78 & 10.26 & 5.48 & 119 \\
\hline 14 & $\mathrm{Al}: \mathrm{P}+Z_{\text {avg }}+\mathrm{Ag}: \mathrm{LA}$ & 0.718 & -13.90 & 12.14 & 5.38 & 119 \\
\hline
\end{tabular}

${ }^{1} \mathrm{RSS}$ is the residual sum of squares.

${ }^{2} n$ is the number of lakes used for model validation. $n=96$ for the DEP lakes; the 23 LEA lakes do not have DOC concentration data and were not included in models 1 and 3. $n=119$ for the DEP and the LEA lakes. 
Table 3.2 Multiple Linear Regression Equation Coefficients. Results include the intercept, $\log \mathrm{P}_{\mathrm{BD}}, \log \mathrm{Al}: \mathrm{P}, \log$ Sch, log Average Depth $\left(Z_{\text {avg }}\right)$, hypolimnetic temperature $\left(\mathrm{T}_{\text {hyp }}\right)$, Adjacent Ag: Lake Area (AdjAg:LA) ratio, Ag:Watershed Area (Ag:WA) ratio, Ag:Lake Area (Ag:LA) ratio, Road:Watershed Area (Rd:WA) ratio, DOC, and $\mathrm{pH}$.

\begin{tabular}{|c|c|c|c|c|c|c|c|c|c|c|c|c|c|}
\hline & Model & intercept & $\begin{array}{l}\log \\
P_{B D} \\
\end{array}$ & $\begin{array}{c}\log \\
\text { Al:P } \\
\end{array}$ & $\mathbf{T}_{\text {hyp }}$ & \begin{tabular}{|l|}
$\log$ \\
Sch \\
\end{tabular} & \begin{tabular}{|l|}
$\log$ \\
$\mathbf{z}_{a v g}$ \\
\end{tabular} & $\begin{array}{c}\text { Adj } \\
\text { Ag:LA }\end{array}$ & Ag: WA & Ag: LA & Rd: WA & DOC & pH \\
\hline 1 & $\mathrm{P}_{\mathrm{BD}}+\mathrm{z}_{\text {avg }}+\mathrm{Adj} \mathrm{Ag}: \mathrm{LA}+\mathrm{DOC}$ & 0.943 & 0.168 & & & & -0.481 & 0.933 & & & & 0.056 & \\
\hline 2 & $\mathrm{P}_{\mathrm{BD}}+\mathrm{z}_{\text {avg }}+\operatorname{AdjAg}: \mathrm{LA}$ & 1.141 & 0.199 & & & & -0.523 & 0.957 & & & & & \\
\hline 3 & $\mathrm{Al}: \mathrm{P}+\mathrm{z}_{\text {avg }}+\mathrm{Adj} \mathrm{Ag}: \mathrm{LA}+\mathrm{DOC}$ & 1.244 & & -0.128 & & & -0.459 & 1.027 & & & & 0.058 & \\
\hline 4 & $\mathrm{P}_{\mathrm{BD}}+\mathrm{z}_{\text {avg }}+\mathrm{AdjAgLA}+\mathrm{pH}$ & 0.938 & 0.187 & & & & -0.515 & 0.904 & & & & & 0.029 \\
\hline 5 & $\mathrm{Al}: \mathrm{P}+\mathrm{z}_{\text {avg }}+\mathrm{Adj} \mathrm{Ag}: \mathrm{LA}$ & 1.522 & & -0.162 & & & -0.499 & 1.047 & & & & & \\
\hline 6 & $\mathrm{P}_{\mathrm{BD}}+\mathrm{z}_{\text {avg }}+\mathrm{Ag}: \mathrm{WA}$ & 1.106 & 0.189 & & & & -0.509 & & 2.024 & & & & \\
\hline 7 & $\mathrm{P}_{\mathrm{BD}}+\mathrm{z}_{\text {avg }}+\mathrm{Rd}: \mathrm{WA}$ & 1.450 & 0.354 & & & & -0.656 & & & & -24.218 & & \\
\hline 8 & $\mathrm{P}_{\mathrm{BD}}+\mathrm{Adj} \mathrm{Ag}: \mathrm{LA}+\mathrm{T}_{\mathrm{hyp}}$ & 0.227 & 0.215 & & 0.027 & & & 1.072 & & & & & \\
\hline 9 & $\mathrm{Al}: \mathrm{P}+\mathrm{z}_{\text {avg }}+\mathrm{Ag}: \mathrm{WA}$ & 1.441 & & -0.141 & & & -0.484 & & 2.266 & & & & \\
\hline 10 & $\mathrm{P}_{\mathrm{BD}}+z_{\text {avg }}+\mathrm{Ag}: \mathrm{LA}$ & 1.160 & 0.282 & & & & -0.554 & & & 0.030 & & & \\
\hline 11 & Al:P+AdjAg:LA+ $\mathrm{T}_{\text {hyp }}$ & 0.665 & & -0.158 & 0.025 & & & 1.209 & & & & & \\
\hline 12 & $\mathrm{Al}: \mathrm{P}+S c h+\mathrm{Adj} A g: \mathrm{LA}$ & 1.323 & & -0.173 & & -0.157 & & 1.135 & & & & & \\
\hline 13 & $\mathrm{P}_{\mathrm{BD}}+S c h+\operatorname{AdjAg}: \mathrm{LA}$ & 0.912 & 0.185 & & & -0.160 & & 1.126 & & & & & \\
\hline 14 & $\mathrm{Al}: \mathrm{P}+\mathrm{Z}_{\text {avg }}+\mathrm{Ag}: \mathrm{LA}$ & 1.742 & & -0.244 & & & -0.527 & & & 0.026 & & & \\
\hline
\end{tabular}




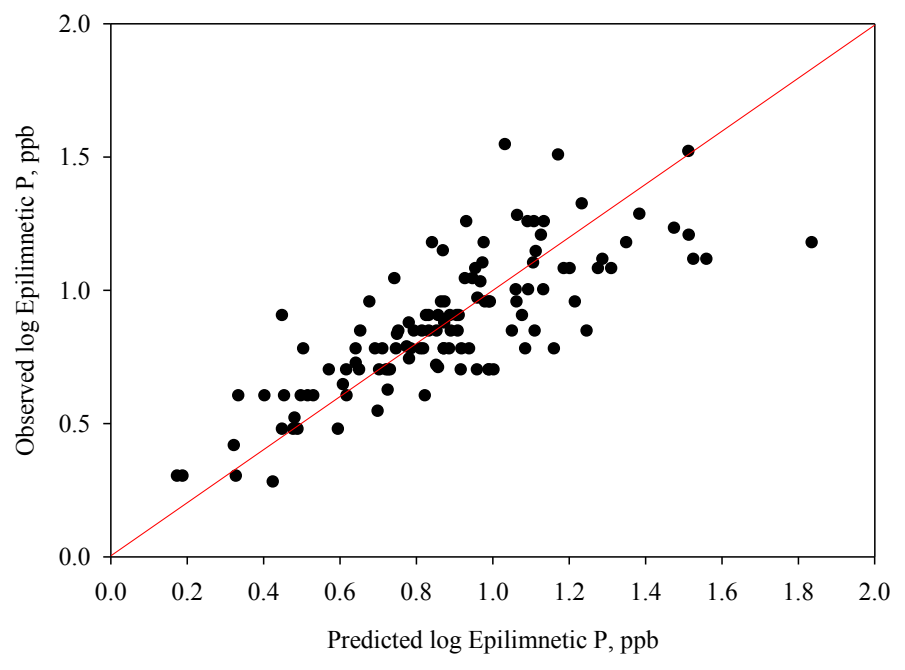

(a)

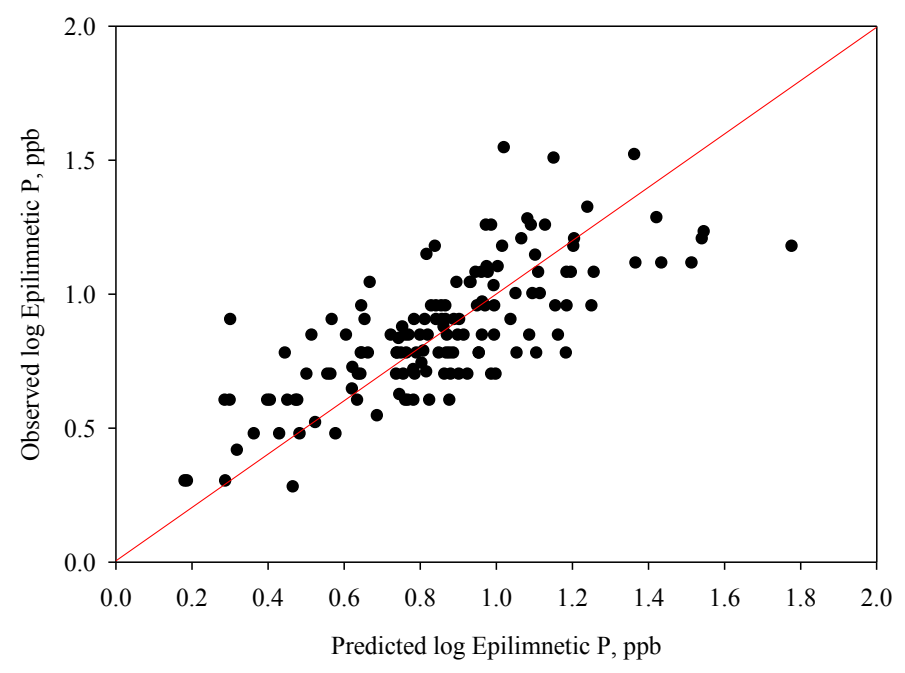

(b)

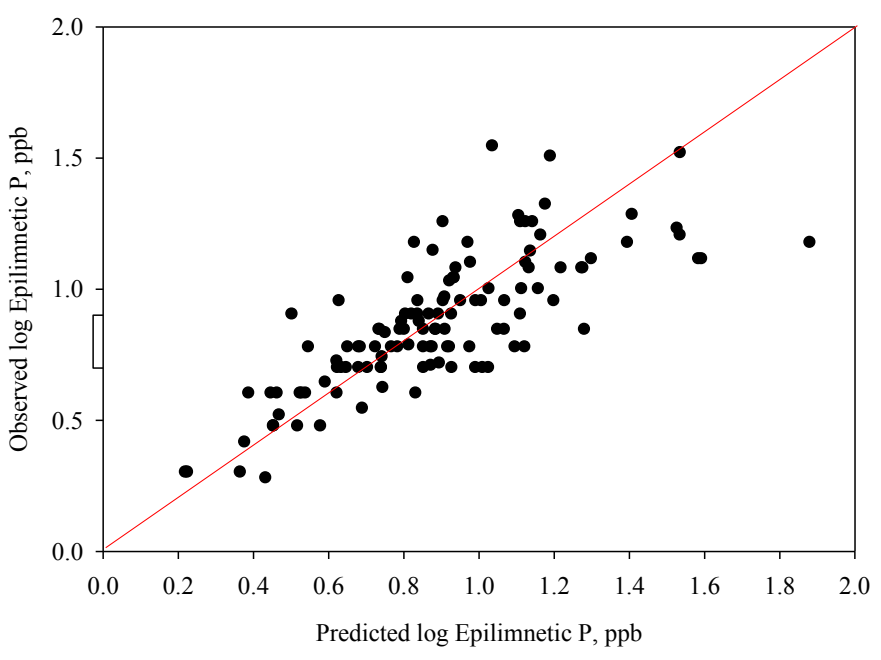

Figure 3.13: The Multiple Linear Regression Model Determined by AIC. The log predicted August epilimnetic P concentration versus the $\log$ measured $P$ concentration of 120 (2015 + DEP) lakes (a, c) and 143 (2015 + DEP + LEA) lakes (b). Red line denotes the 1:1 line. The top three models according to AIC are shown. (a) Model 1, AIC = -26.04; (b) Model 2, AIC $=-25.08$; (c) Model 3, $\mathrm{AIC}=-23.47$.

(c) 


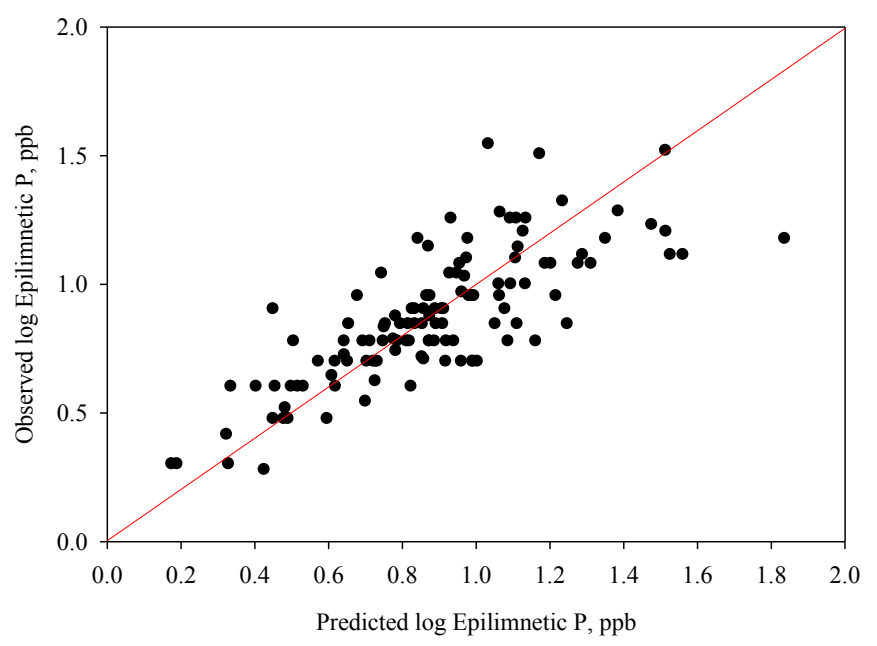

(a)

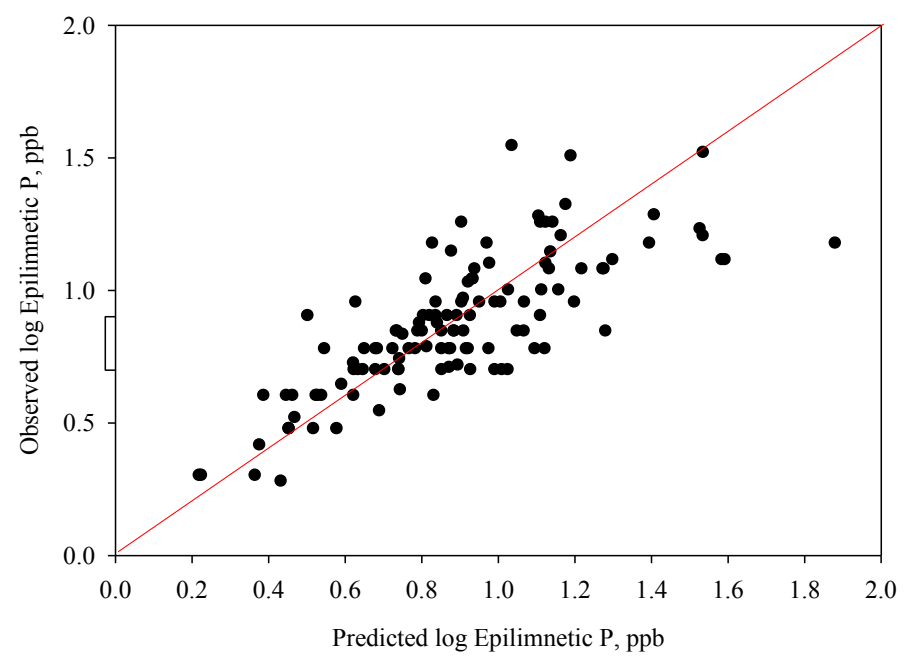

(b)

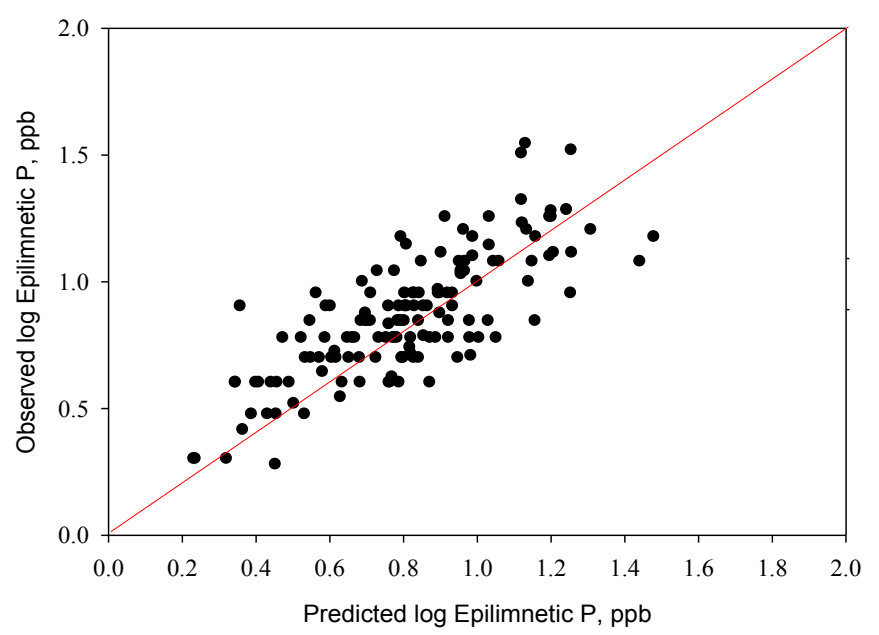

Figure 3.14: The Multiple Linear Regression Model Determined by RSS. The log predicted August epilimnetic P concentration versus the log measured $\mathrm{P}$ concentration of 120 (2015 + DEP) lakes (a, b) and 143 (2015 + DEP + LEA) lakes (c). Red line denotes the 1:1 line. The top three models according to RSS are shown. (a) Model 1, RSS = 3.84; (b) Model 3, RSS = 3.89; (c) Model 9, RSS = 3.90.

(c) 


\subsubsection{Quantile Regression}

The quantile regression (QR) technique was utilized based on the results of MLR model 9 (Table 3.1) because the model provided the best fit when considering the full 119 (DEP + LEA) validation data points. Adopting a method of percentile selection (PS; $\mathrm{Xu}$ et al., 2015), we analyzed the response of Ag:WA ratio to epilimnetic P under ranked $\mathrm{Al}: \mathrm{P}$ and $Z_{\text {avg }}$ concentrations. We target lakes that may be more susceptible to the release of sediment reducible $\mathrm{P}$, by using the lowest ranked sediment $\mathrm{Al}: \mathrm{P}$ ratios. Ranked $\mathrm{Al}: \mathrm{P}$ ratios range from 2.4 to 158.4 for the $75^{\text {th }}$ percentile $(n=108)$, and 2.4 to 84.1 for the $50^{\text {th }}$ percentile $(n=73)$. By ranking concentrations of $Z_{a v g}$ we target the lower $Z_{a v g}$ values i.e. shallower lakes that may be more susceptible to internal P release. Ranked $Z_{\text {avg }}$ values range from 1.1 to $13.1 \mathrm{~m}$ for the $75^{\text {th }}$ percentile $(n=108)$, and 1.1 to $8.3 \mathrm{~m}$ for the $50^{\text {th }}$ percentile $(n=73)$. We did not report the $25^{\text {th }}$ percentile because the number of data points is only 36 . Consequently, the ranked data became more variable when considering upper boundary quantiles $\left(90^{\text {th }}\right.$ quantile and above) for the model.

We used an arbitrary threshold of $15 \mathrm{ppb}(\log 1.18)$ for the August epilimnetic P and the $80^{\text {th }}$ quantile model to assess lake vulnerability with respect to agricultural development in the watershed (Figure $3.15 ; 3.16 ; 3.17 ; 3.18$ ). Below 15 ppb the lakes range from oligotrophic to lower mesotrophic, while above this threshold lakes are more at risk for eutrophication. The $80^{\text {th }}$ quantile $\log \mathrm{P}$ is the value where $80 \%$ of the lakes have concentrations less than or equal to $15 \mathrm{ppb}$. This analysis was performed for lakes with sediment $\mathrm{Al}: \mathrm{P}$ ratios below the $75^{\text {th }}$ and $50^{\text {th }}$ percentiles (Figure $3.15 ; 3.16$ ) and lakes with $Z_{\text {avg }}$ values below the $75^{\text {th }}$ and $50^{\text {th }}$ percentiles (Figures $3.17 ; 3.18$ ). The crossing of the $80^{\text {th }}$ quantile model and the threshold $\mathrm{P}$ concentration marks the predicted Ag:WA 
ratio that should not be exceeded in order to maintain an epilimnetic P concentration of $15 \mathrm{ppb}$. The threshold value for the Ag:WA ratio for lakes in the $75^{\text {th }}$ percentile of sediment $\mathrm{Al}: \mathrm{P}$ ratio is 0.11 . When lakes in the $50^{\text {th }}$ percentile of sediment $\mathrm{Al}: \mathrm{P}$ ratio are considered, the threshold value for the Ag:WA ratio is reduced to 0.09 (Figure 3.15; 3.16). The Ag:WA ratio threshold for lakes in the $75^{\text {th }}$ percentile of $Z_{\text {avg }}$ is 0.078 , which is further reduced to 0.068 for lakes in the $50^{\text {th }}$ percentile of $Z_{\text {avg }}$ (Figure $3.17 ; 3.18$ ). Exceeding these threshold Ag:WA ratios predicts higher August epilimnetic $\mathrm{P}$ concentration than $15 \mathrm{ppb}$.

The PS-QR observations included the entire data set representing 143 lakes across Maine. Trophic state ranged primarily from oligotrophic to mesotrophic, with a few eutrophic lakes. The intercepts and slopes of the log epilimnetic P concentrations versus the Ag:WA ratio for various quantiles for lakes in the $75^{\text {th }}$ percentile of Al:P ratios exhibit increases from 0.40 to 1.15 , and a decrease from 3.50 to 3.10, respectively (Figure $3.15 \mathrm{~b} ; \mathrm{c})$. For lakes with the sediment $\mathrm{Al}: \mathrm{P}$ ratios in the $50^{\text {th }}$ percentile, the intercepts and slopes remain nearly unchanged, ranging from 0.40 to 1.20 and 3.50 to 3.10 , respectively (Figure 3.16b; c). The intercepts and slopes for lakes in the $75^{\text {th }}$ percentile of $Z_{\text {avg }}$ exhibit increases from 0.56 to 1.15 and 2.00 to 3.20, respectively (Figure 3.17b; c). For lakes with $Z_{\text {avg }}$ in the $50^{\text {th }}$ percentile, the intercepts and slopes remain nearly unchanged ranging from 0.60 to 1.16 and 2.40 to 3.20 , respectively (Figure 3.18 b; c). The quantile slope estimates are not statistically different from the linear regression (LR) estimate (Figure $3.15 \mathrm{c} ; 3.16 \mathrm{c} ; 3.17 \mathrm{c} ; 3.18 \mathrm{c})$. 

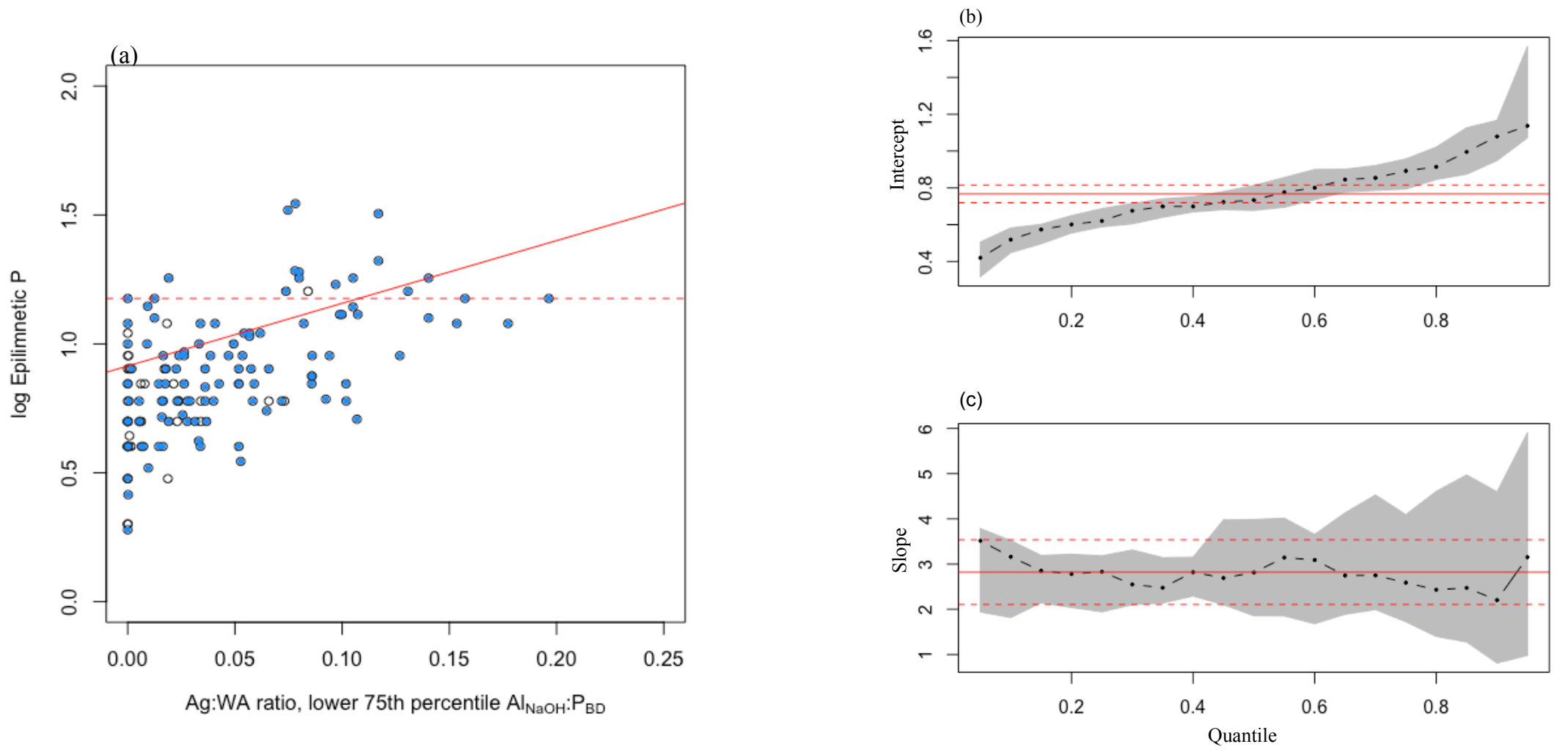

Figure 3.15: Ag:WA, lower $75^{\text {th }}$ percentile Al:P versus log epilimnetic P: (a) The $80^{\text {th }}$ quantile QR models (solid red line) for log epilimnetic $\mathrm{P}$ as a function of $\mathrm{Ag}$ :WA ratio (gray unfilled circles) for ranked Al:P values ( $75^{\text {th }}$; blue filled circles). The thresholds for the epilimnetic $\mathrm{P}$ concentrations for limiting a specific $\mathrm{Ag}$ :WA target (log epilimnetic $\mathrm{P}=1.18$ corresponds to 15 ppb, dashed red line). (b) intercepts $\left(b_{0}\right.$, black dotted lines: slope; gray bars: $95 \%$ confidence intervals; red dashed lines is the Linear Regression estimates) for the equation, $\log$ epilimnetic $\mathrm{P}=\mathrm{b}_{0}+\mathrm{b}_{1} \log \mathrm{Ag}$ :WA $+\varepsilon(\mathrm{b}, \mathrm{c})$ with increasing quantiles of all observations. (c) The slopes are for the equation, $\log$ epilimnetic $\mathrm{P}=\mathrm{b}_{0}+\mathrm{b}_{1} \log \mathrm{Ag}: \mathrm{WA}+\varepsilon(\mathrm{b}, \mathrm{c}) \quad\left(\mathrm{b}_{1}\right.$ values are black dots, $95 \%$ confidence intervals are shaded gray: red solid line is the Linear Regression estimates). 
(a)

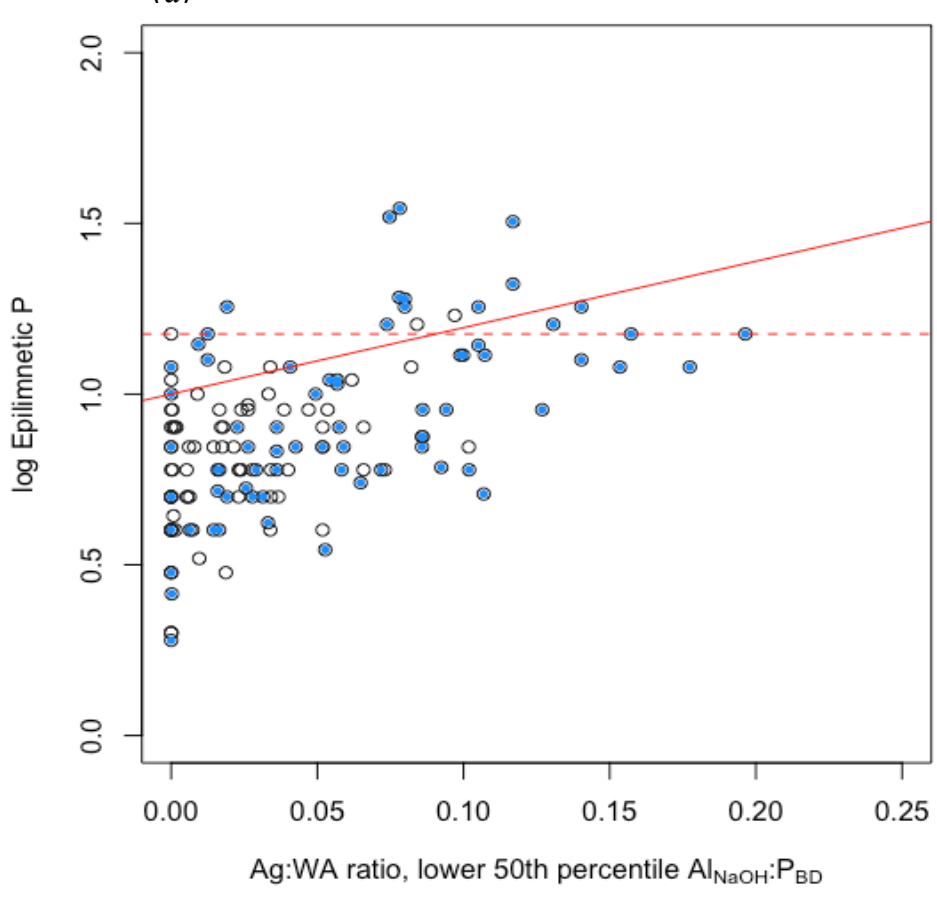

(b)

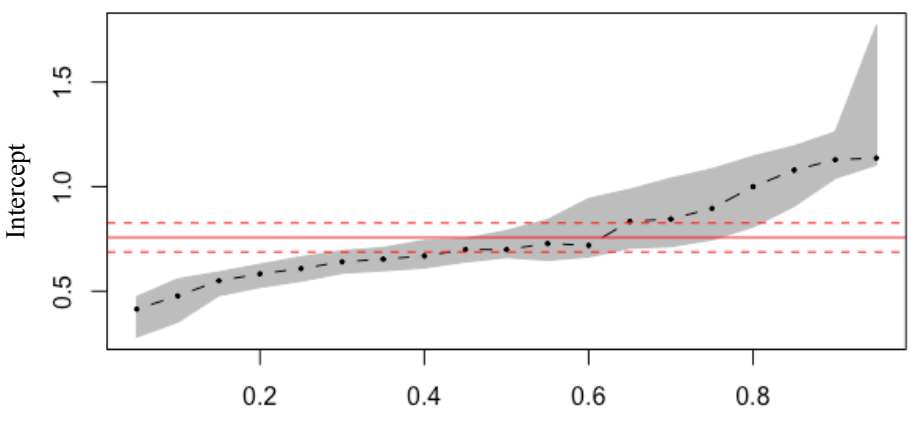

(c)

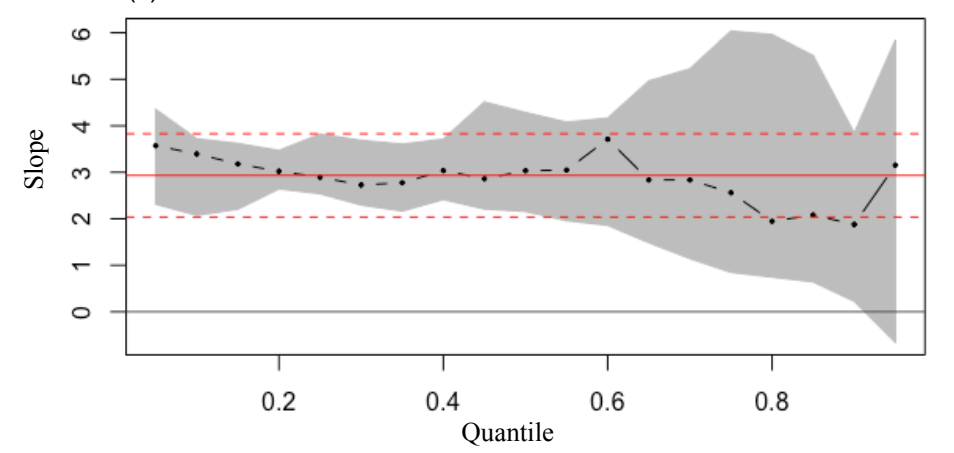

Figure 3.16: Ag:WA, lower $75^{\text {th }}$ percentile Al:P versus log epilimnetic P: (a) The $80^{\text {th }}$ quantile QR models (solid red line) for log epilimnetic $\mathrm{P}$ as a function of Ag:WA ratio (gray unfilled circles) for ranked Al:P values (50 ${ }^{\text {th }}$; blue filled circles). The thresholds for the epilimnetic P concentrations for limiting a specific Ag:WA target (log epilimnetic $\mathrm{P}=1.18$ corresponds to 15 ppb, dashed red line). (b) intercepts ( $b_{0}$, black dotted lines: slope; gray bars: 95\% confidence intervals; red dashed lines is the Linear Regression estimates) for the equation, $\log$ epilimnetic $\mathrm{P}=\mathrm{b}_{0}+\mathrm{b}_{1} \log \mathrm{Ag}: \mathrm{WA}+\varepsilon(\mathrm{b}, \mathrm{c})$ with increasing quantiles of all observations. (c) The slopes are for the equation, $\log$ epilimnetic $\mathrm{P}=\mathrm{b}_{0}+\mathrm{b}_{1} \log \mathrm{Ag}$ :WA $+\varepsilon(\mathrm{b}, \mathrm{c})\left(\mathrm{b}_{1}\right.$ values are black dots, $95 \%$ confidence intervals are shaded gray: red solid line is the Linear Regression estimates). 

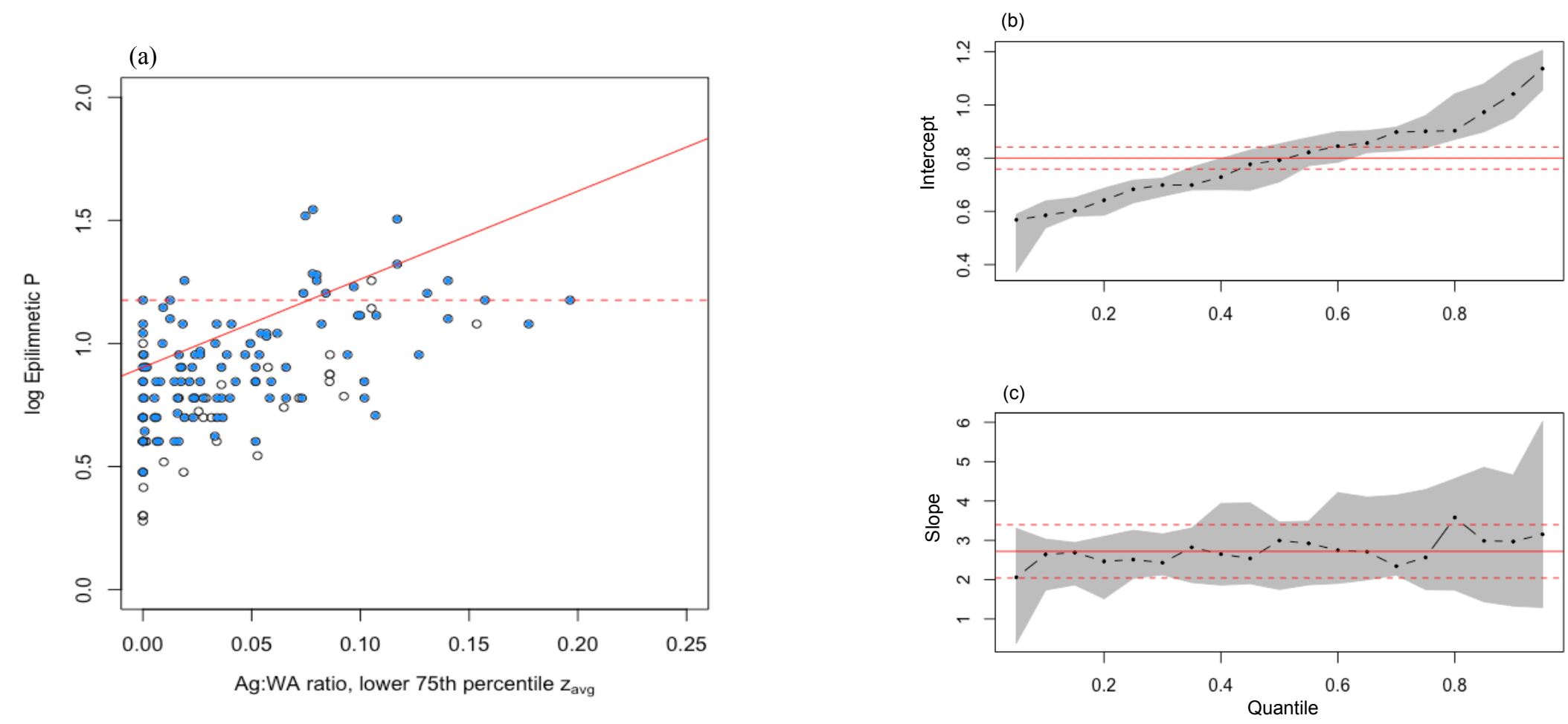

Figure 3.17: Ag:WA, lower $75^{\text {th }}$ percentile $Z_{\text {avg }}$ versus log epilimnetic P: (a) The $80^{\text {th }}$ quantile QR models (solid red line) for log epilimnetic $\mathrm{P}$ as a function of $\mathrm{Ag}$ :WA ratio (gray unfilled circles) for ranked Zavg values ( $75^{\text {th }}$; blue filled circles). The thresholds for the epilimnetic $\mathrm{P}$ concentrations for limiting a specific Ag:WA target (log epilimnetic $\mathrm{P}=1.18$ corresponds to $15 \mathrm{ppb}$, dashed red line). (b) intercepts ( $b_{0}$, black dotted lines: slope; gray bars: $95 \%$ confidence intervals; red dashed lines is the Linear Regression estimates) for the equation, $\log$ epilimnetic $\mathrm{P}=\mathrm{b}_{0}+\mathrm{b}_{1} \log \mathrm{Ag}$ :WA $+\varepsilon(\mathrm{b}, \mathrm{c})$ with increasing quantiles of all observations. (c) The slopes are for the equation, $\log$ epilimnetic $\mathrm{P}=\mathrm{b}_{0}+\mathrm{b}_{1} \log \mathrm{Ag}$ :WA $+\varepsilon(\mathrm{b}, \mathrm{c}) \quad\left(\mathrm{b}_{1}\right.$ values are black dots, $95 \%$ confidence intervals are shaded gray: red solid line is the Linear Regression estimates). 

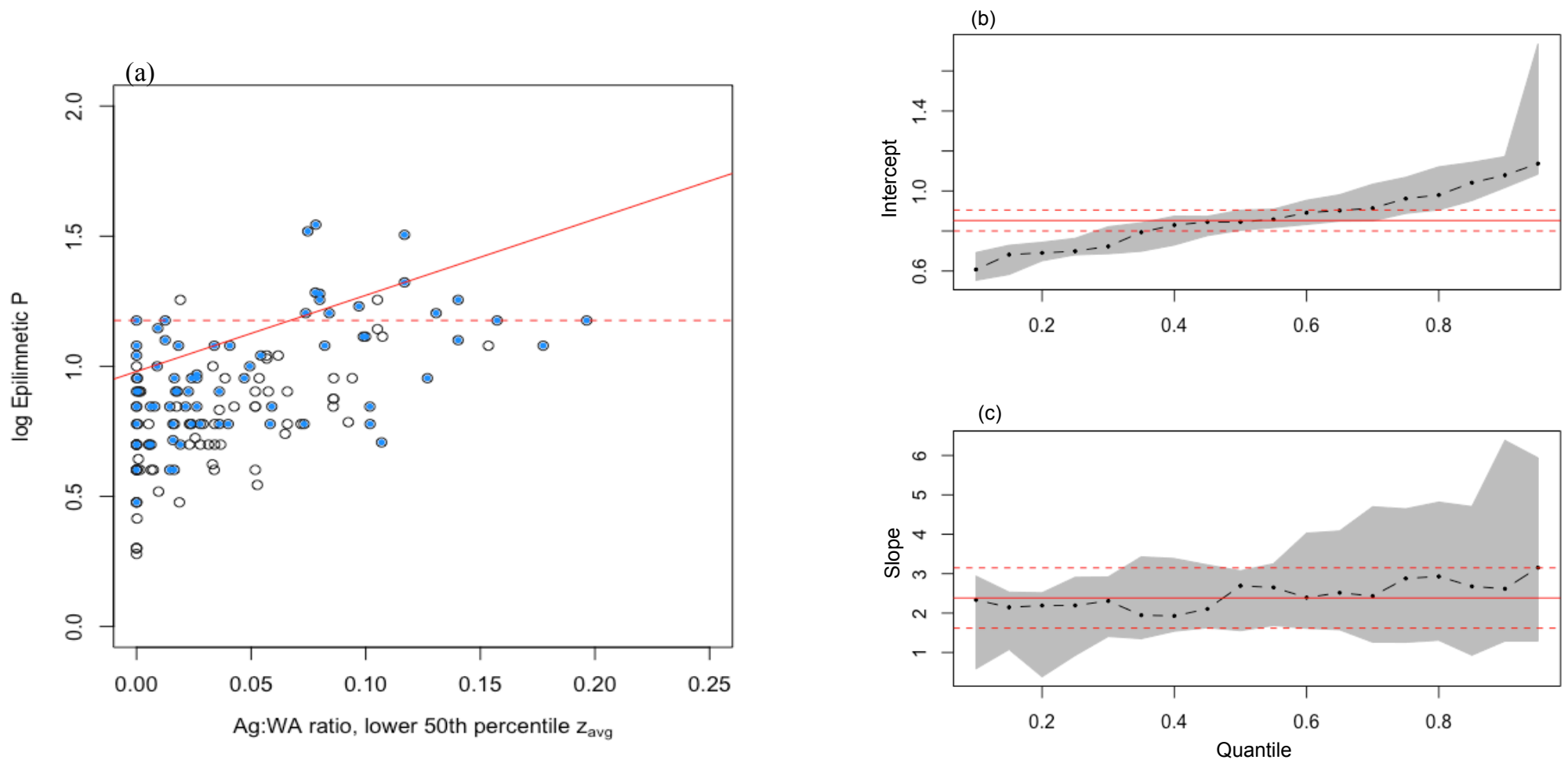

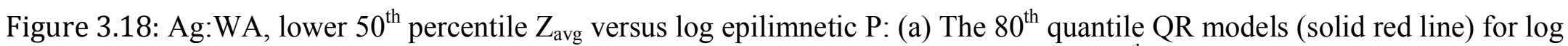
epilimnetic $\mathrm{P}$ as a function of Ag:WA ratio (gray unfilled circles) for ranked Zavg values ( $50^{\text {th }}$; blue filled circles). The thresholds for the epilimnetic P concentrations for limiting a specific Ag:WA target (log epilimnetic $\mathrm{P}=1.18$ corresponds to 15 ppb, dashed red line). (b) intercepts $\left(b_{0}\right.$, black dotted lines: slope; gray bars: 95\% confidence intervals; red dashed lines is the Linear Regression estimates) for the equation, $\log$ epilimnetic $\mathrm{P}=\mathrm{b}_{0}+\mathrm{b}_{1} \log \mathrm{Ag}$ :WA $+\varepsilon(\mathrm{b}, \mathrm{c})$ with increasing quantiles of all observations. (c) The slopes are for the equation, $\log$ epilimnetic $\mathrm{P}=\mathrm{b}_{0}+\mathrm{b}_{1} \log \mathrm{Ag}: \mathrm{WA}+\varepsilon(\mathrm{b}, \mathrm{c})\left(\mathrm{b}_{1}\right.$ values are black dots, $95 \%$ confidence intervals are shaded gray: red solid line is the Linear Regression estimates). 


\section{CHAPTER 4: DISCUSSION}

Phosphorus is the limiting nutrient in lake ecosystems, and thus controls lake productivity. Traditionally, models used to simulate and predict lake water quality have focused on external P inputs (Dillon and Kirchner, 1975; Vollenweider, 1976). However, these models fail to correctly model lakes in which internally loaded P contributes a significant amount of P (Søndergaard et al. 2013). This behavior occurs when lakes remain eutrophic after external $\mathrm{P}$ has been significantly reduced. In such lakes, internal loading is responsible for delaying the expected lake recovery (Jeppesen et al., 2005; Søndergaard et al., 2013). In our approach to predict the lake summer epilimnetic P concentration, we quantified the effects of physiochemical, climate, and watershed factors that relate to improved water quality to include both the internal and external $\mathrm{P}$ budgets. Our goal was to create simplified models that can be used for lake water quality management. We present three approaches for predicting water quality conditions based on quantified variables: the regression tree, multiple linear regression (MLR) models, and percentile selection quantile regression (PS-QR) model.

\subsection{Regression Tree Model}

Regression tree analysis is suitable for nonlinear relationships among the predictor and response variables (Figures 3.1-3.6; 3.9). In this approach, the response variable is based on several input variables. The model produces simple and interpretable results that can be validated. Regression trees explain the variation of a single response variable, in this case epilimnetic P, by splitting the data into homogenous groups (De'Ath and Fabricius, 2000). In the context of this study, however, the regression tree may be 
best utilized as a first estimate to determine the dominant variables that predict lake water quality. The analysis predicts the statistical fit for a population of lakes to determine a statistical threshold value.

The regression tree determined $S c h, \mathrm{Adj} A g: \mathrm{LA}$, and $\mathrm{pH}$ to be the most important parameters in determining the response variable, epilimnetic P (Figure 3.12). Schmidt Stability (Sch) at $95 \mathrm{~J} / \mathrm{m}^{2}$ was the first threshold in the regression tree model. A low $S c h$ indicates that a lake mixes more easily or has just partially mixed, and thus is potentially subject to upwelling of high P hypolimnetic waters, with a relatively small energy input normally provided by wind. A high $S c h$ indicates a lake is less likely to mix. This split suggests the importance of water column thermal stability on epilimnetic P concentration.

The second threshold identified was AdjAg:LA, a watershed land-use characteristic. This parameter may be regarded as a proxy for external P inputs. The greater the AdjAg:LA ratio the greater the lake epilimnetic $\mathrm{P}$ concentration, as evidenced by the second split; lakes with AdjAg:LA ratio $<0.066$ have epilimnetic $\mathrm{P}$ concentrations $<9.9 \mathrm{ppb}$, qualifying as oligotrophic. Together, lakes with a $S c h<95 \mathrm{~J} / \mathrm{m}^{2}$ and a AdjAg:LA ratio $>0.066$ have epilimnetic $\mathrm{P}$ concentrations $>20 \mathrm{ppb}$ that places them in the mesotrophic-eutrophic category.

Lastly, $\mathrm{pH}$ proved to be an important lake chemical predictor variable in the regression tree. The model suggests that lakes with an epilimnetic $\mathrm{pH} \geq 7.7$ possess a higher mean epilimnetic $\mathrm{P}$ concentration $(12 \mathrm{ppb})$, whereas lakes with a $\mathrm{pH}<7.7$ have a mean $\mathrm{P}$ concentration $=4.8 \mathrm{ppb}$. The identification of $\mathrm{pH}$ as a predictor variable in the regression tree may be due to its correlation with other significant predictor variables. $\mathrm{pH}$ correlates positively and significantly $(\mathrm{p}<0.05)$ with sediment $\mathrm{P}_{\mathrm{BD}}$ and the $\mathrm{Ag}$ :WA ratio 
(data not shown), two parameters that are prominent predictors of the epilimnetic $\mathrm{P}$ in several of our top MLR models (Table 3.1). Ag:WA may link to $\mathrm{pH}$ through the use of soil amendments, such as $\mathrm{CaCO}_{3}$ which produces alkalinity, and P-containing fertilizer which promotes higher $\mathrm{pH}$ through greater photosynthesis.

Surprisingly among the lake chemical predictor variables, sediment parameters such as $\mathrm{P}_{\mathrm{BD}}$ and $\mathrm{Al}_{\mathrm{NaOH}}: \mathrm{P}_{\mathrm{BD}}$ were not identified as important to the regression tree. We expected predictors of internal release or internal storage (Carey and Rydin, 2011; Homyak et al., 2014) to be included in the regression tree, as thresholds for $\mathrm{Al}_{\mathrm{NaOH}}: \mathrm{P}_{\mathrm{BD}}$ have been previously established (Kopáček et al., 2005), and $\mathrm{P}_{\mathrm{BD}}$ represents the potentially mobile $\mathrm{P}$ under anaerobic conditions (Rydin et al., 2000). Further, these two variables are predictors in our top MLR models (Table 3.1).

The regression tree model does not provide a parameter indicative of potential internal P load. However, this model does support our hypothesis that physiochemical, climate, and watershed characteristics are important in determining the epilimnetic $\mathrm{P}$, as the first three splits encompass each of these factors. AdjAg:LA ratio is a predictor variable in our top MLR models (Table 3.1).

\subsection{Multiple Linear Regression Models}

We developed the MLR models to predict lake August epilimnetic $\mathrm{P}$ concentrations from a set of easily measurable predictor variables (Tables 4.1 and 4.2). The models were developed for a set of 24 (2015) lakes sampled within a two-week period in August 2015. To validate the models, we calculated the residual sum of the squares (RSS) for the August epilimnetic P concentrations on a set of 119 (DEP + LEA) 
lakes (Table 3.1) that were sampled from 2010 to 2013 (Appendix C). The MLR models can be used as a predictive tool, allowing us to evaluate lake vulnerability to eutrophication and deterioration of water quality. Through epilimnetic P prediction, stakeholders, from homeowners to the Maine Department of Environmental Protection (DEP), can make decisions to best maintain or identify lakes for which remediation is a priority to improve water quality. The models and approach developed here can be used by regulatory agencies in other states to develop lake management strategies for similar lakes. This approach can be applied by the larger research community, as a blueprint to investigate the roles of these or other, as yet, untested predictor variables in lake water quality.

Models 1, 3, and 9 (Figure 3.14; Table 3.1) outperformed the other models in terms of providing the closest estimate for the measured epilimnetic $\mathrm{P}$ values. The MLR models with minimized residual error partially support our hypothesis that physiochemical, climate, and weather parameters influence epilimnetic $\mathrm{P}$ concentration. The most important predictors in the top MLR models are: $\mathrm{Al}_{\mathrm{NaOH}}: \mathrm{P}_{\mathrm{BD}}, \mathrm{P}_{\mathrm{BD}}, \mathrm{Z}_{\text {avg }}, \mathrm{DOC}$, Ag:WA, and AdjAg:LA (Table 3.1). These models each consist of one watershed parameter and two or more physiochemical parameters; these parameters act as proxies for internal and external P loading.

Ecologically it is reasonable that sediment $\mathrm{Al}_{\mathrm{NaOH}}: \mathrm{P}_{\mathrm{BD}}$ ratio and $\mathrm{P}_{\mathrm{BD}}$ are included in the most effective models because they determine the extent to which internal P will be sequestered or released (Kopáček et al., 2005; Lake et al., 2007; Carey and Rydin, 2011; Homyak et al., 2014). It is also reasonable to include a proxy such as AdjAg:LA or $\mathrm{Ag}$ :WA for P export from the watershed, as evidenced by previous work focusing on the 
external P budget of a lake (Dillon and Kirchner, 1974). The area-averaged depth, $Z_{\text {avg, }}$, represents the relationship between lake depth and morphometry of the basin. Its value can be related to the lake bottom temperature, as well as the lake's propensity to mix vertically.

Parameters that reflect the effect of climate/weather, such as $S c h, \mathrm{~T}_{\text {hyp }}$ and precipitation, did not appear in the top MLR models ( $\triangle \mathrm{AIC}<2$; Table 3.1). As regional warming continues, it is likely to be accompanied by changes to water column temperature, precipitation, and increased storm frequency (Gerten and Adrian, 2002). Warming promotes a longer growing season in lakes. The $S c h$, as a weather-related parameter, does not definitively determine whether a lake mixes or remains stable (Robertson and Imberger, 1994), because it does not account for the effect of wind intensity. Further, $S c h$ reflects the lake tendency to mix only immediately prior to the day of sampling, it is not reflective of the conditions over the entire season. However, Sch correlates strongly and significantly with $Z_{\text {avg }}\left(\mathrm{R}^{2}=0.76, \mathrm{p}<0.001\right)$. Statistically, including $Z_{\text {avg }}$ in the MLR models results in stronger correlations compared to including $S c h$ (Table 3.1). As such, $Z_{\text {avg }}$ may be considered as a parameter that also reflects the tendency of a lake to mix.

Cumulative (from January-August and May-August) and maximum precipitation were tested in the regression tree model because increased precipitation leads to increased $\mathrm{P}$ export from the watershed; models including precipitation parameters failed to predict the August epilimnetic P significantly and were not included in Table 3.1 (Appendix C2.1). 
A warmer hypolimnetic temperature enhances microbial metabolic rates, especially in the profundal sediment (Nürnberg, 1995). Therefore, a higher $\mathrm{T}_{\text {hyp }}$ should

cause more extensive hypolimnetic anoxia and release of sediment $\mathrm{P}$. However, $\mathrm{T}_{\text {hyp }}$ does not appear as a predictor variable in the top MLR models (Table 3.1).

The top MLR models gave nearly identical results in terms of $\mathrm{R}^{2}$ (Table 3.1) likely due to sharing many similar variables. Given the limited number of lakes used for model calibration and validation ( $\mathrm{n}=24$ and 119 , respectively) any of the models in Table 3.1 may be the most suitable for a given lake. For example, when applied to the validation data set of 119 lakes, model 9 nearly had the lowest error in predicting the epilimnetic P. As such, provided that the data are available, we propose that all of the models in Table 3.1 may be applied to predict the lake epilimnetic P. Individual lakes of significance, may be scrutinized for unusual conditions if their predicted P differs greatly from actual $\mathrm{P}$ (see section 4.4 , below).

\subsection{Percentile Selection-Quantile Regression}

We employed the percentile selection quantile regression (PS-QR) method to detect the relative importance of the Ag:WA ratio in controlling the lake epilimnetic $\mathrm{P}$ for lakes at the lower end of the spectrum of sediment Al:P ratio and $Z_{\text {avg. }}$ The law of limiting factors (Liebig's law of minimum) is a basic principle of ecology, which holds that when a process relies on several factors, the process will be constrained by the least available factor (Kaiser et al., 1994). In order to account for a limiting factor, a model must be able to consider the upper boundary of a distribution. Typical models, such as linear regression, measure goodness of fit over the entire distribution of data and include 
effects of secondary factors (Cade et al., 1999); this approach models the distribution of data based on the conditional mean, which is ineffective when developing models based on limiting factors. QR is capable of measuring goodness of fit over a specific quantiles' distribution, and is therefore able to target limiting thresholds for populations by estimating changes within the upper boundary (Kaiser et al., 1994; Cade et al., 1999).

Since PS-QR is statistically robust and can be used as a tool for developmental planning and management of lakes based on limiting nutrients (such as epilimnetic P), we utilized it to predict the $\mathrm{Ag}$ :WA ratio thresholds required to control lake epilimnetic $\mathrm{P}$ concentrations. This approach is modeled after (Xu et al., 2015) in which threshold lake $\mathrm{TP}$ and $\mathrm{TN}$ concentrations were estimated for target $\mathrm{Chl}$ a concentrations in Lake Champlain, Vermont, USA.

In this study, the $80^{\text {th }}$ quantile of the August epilimnetic $\mathrm{P}$ versus the Ag:WA ratio was selected based on the PS-QR models' slope $\left(b_{1}\right)$, intercept $\left(b_{0}\right)$, and number of lakes (n). In QR, the confidence interval endpoints may not be symmetric about the estimate (Koenker, 1994), which is consistent with the sampling distribution having a smaller $n$ at the more extreme quantiles (Cade et al., 1999; Cade and Noon, 2003). Close to these extremes the sampling variation for quantiles is highly variable, and if the confidence intervals include the zero slope, the specific quantile is not considered significant. For example, the confidence interval for the $90^{\text {th }}$ quantile of Figure 3.16c is narrow enough to exclude zero, but the confidence interval for the $95^{\text {th }}$ quantile is wider and includes zero. The $95^{\text {th }}$ quantile of the slope includes zero (Figure 3.16c). Therefore it is not significant nor a suitable quantile for the model. In this study, we used data from 108 lakes for the $75^{\text {th }}$ percentile of the ranked $\mathrm{Al}: \mathrm{P}$ ratios and $Z_{\text {avg }}$, and 73 lakes for the $50^{\text {th }}$ percentile of 
the ranked Al:P ratio and $Z_{\text {avg }}$ from the original 143 lakes. At the $90^{\text {th }}$ quantile, only 11 lakes for the $75^{\text {th }}$ percentile and 7 lakes for the $50^{\text {th }}$ percentile ranked Al:P ratios and $Z_{\text {avg }}$ would have been included. Therefore, we chose to model the $80^{\text {th }}$ quantile instead of the $90^{\text {th }}$ or higher because it produces a greater range of upper regression quantiles with similar slope estimates, less sampling variation, and smaller confidence intervals (Figure $3.15 ; 3.16 ; 3.17 ; 3.18)$. However, quantiles greater than the $80^{\text {th }}$ could be considered reasonable, with an addition of data from more lakes, as long as the slope and intercepts are statistically significant (Cade et al., 1999; Xu et al., 2015).

An advantage of PS-QR over the standard linear regression method is it can provide a more reliable prediction of the threshold Ag:WA ratio necessary to limit the lake summer epilimnetic $\mathrm{P}$ concentration to a specific target value. To constrain the epilimnetic $\mathrm{P}$ to a target concentration $<15 \mathrm{ppb}$ in the $80^{\text {th }}$ quantile, the predicted Ag:WA ratio thresholds for the lakes with the $75^{\text {th }}$ and $50^{\text {th }}$ percentile $\mathrm{Al}: \mathrm{P}$ ratio are 0.11 and 0.09 , respectively (Figure $3.15 ; 3.16$ ). To constrain the epilimnetic $\mathrm{P}$ concentration to the same value, the predicted Ag:WA ratio thresholds for the lakes with the $75^{\text {th }}$ and $50^{\text {th }}$ percentile $Z_{\text {avg }}$ are 0.078 and 0.068 , respectively (Figure $3.17 ; 3.18$ ). Therefore, threshold values for the Ag:WA ratios become more constrained when comparing lakes with $75^{\text {th }}$ and $50^{\text {th }}$ percentiles in the Al:P ratios and $Z_{\text {avg }}$ values. This is reasonable considering that lakes in the lower percentiles of the $\mathrm{Al}: \mathrm{P}$ ratios and $Z_{\text {avg }}$ values are more vulnerable to eutrophication. Considering lakes in the $25^{\text {th }}$ percentile of $\mathrm{Al}: \mathrm{P}$ ratios and $Z_{\text {avg }}$ values would decrease the threshold Ag:WA ratio in order to maintain the same predicted epilimnetic $\mathrm{P}$ concentration; however, we did not report the data because sample variance captured by the slope of the distribution increased significantly and the $80^{\text {th }}$ quantile slope 
is not significantly different from zero; therefore the $80^{\text {th }}$ quantile would not be usable for this model.

The PS-QR method can be used as a management strategy to constrain predictor variable(s) to achieve a target water quality level; in this study, we used it to estimate the threshold Ag:WA ratio for lakes in a certain percentile $\mathrm{Al}: \mathrm{P}$ ratios and $Z_{\text {avg }}$ values for the target epilimnetic $\mathrm{P}$ concentration of $15 \mathrm{ppb}$. Thresholds were developed as a statistical fit for the population of lakes, not for an individual lake. Therefore thresholds represent an increased possibility of problems upon approaching or exceeding a threshold. The confidence in a prediction for an individual lake can be assessed by inspection of Figures 3.15-3.18. Smaller populations in any model increase the margin of error. The use of the $\mathrm{Ag}$ :WA ratio among other predictor variables is because its value can be managed by a regulatory agency through a combination of best management practices and zoning of land use.

\subsection{Modeling Limitations}

The models developed in this study utilized 24 lakes that were sampled in 2015. These lakes ranged from 1.9 to $21.0 \mathrm{ppb}$ in the August epilimnetic $\mathrm{P}$ concentration, spanning oligotrophic to mesotrophic states. The data set that was used for model validation consisted of a total of 119 lakes that were sampled from 2010 to 2013 by the DEP and LEA; these lakes are mostly oligotrophic and mesotrophic, and cover a narrower range of productivity compared to the 2015 lakes. Developing predictive models for lakes with a full range of productivity (oligotrophic to eutrophic) typically improves model predictability for a wider range of lakes. 
Assumptions made in the choice of modeling parameters may have added uncertainty to the results. Estimates of agricultural land were based on GIS landcover maps from 2004. These maps provide acreage of pasture/hay lands and cultivated croplands without consideration of the type of crops, frequency of cultivation, and specific agricultural practice with respect to the addition of fertilizers and pesticide.

Future research can focus on identification of lake-specific characteristics that relate to water quality problems. For example, by identifying unusual hydric soils or unusual lake hydraulics, researchers could begin to account for the remaining unexplained variation of epilimnetic P. We purposely chose boreal lakes without unusual hydraulic properties in order to decrease variability among the lakes as a whole. Future studies could include more dimensional lakes such as those with multiple deep basins (Sebago Lake, Maine), lakes with inflow/outflow locations in close proximity (Pushaw Lake, Maine), run of river dams in which there is limited water storage, and lakes affected by dam management practices concerning the spring refilling and fall draw down. There will always be exceptions to the models created because all the assumptions may not be valid for each individual lake.

Future refinement to this study could also focus on geological properties within the watershed to determine if certain areas are more susceptible to natural sources of external P. For example, the Presumpscot Formation is composed of marine clay, which has been glacially deposited along the coast of Maine (Davis et al., 1978) and contains $P$ in the form of apatite. Generally, a lake with a watershed on marine clay has a trophic range from mesotrophic to eutrophic while a lake situated in till has a range from oligotrophic to mesotrophic (Lake et al., 2007); the Presumpscot Formation is significant 
because clay-rich soils are easily eroded, which causes increased nutrient fluxes and higher sediment accumulation rates. The effects of natural P loading should be further studied by a comparison of watershed soils and yield of P, with and without Presumpscot Formation present. 


\section{CHAPTER 5: CONCLUSIONS}

This study identified drivers of lake vulnerability to eutrophication. The lake vulnerability models developed here show that lake eutrophication is the result of the combined effects of physiochemical, climate, and watershed factors. Lakes with unfavorable sediment geochemistry (i.e., low $\mathrm{Al}_{\mathrm{NaOH}}: \mathrm{P}_{\mathrm{BD}}$ ratios or high $\mathrm{P}_{\mathrm{BD}}$ concentrations) are more vulnerable to internal P release. Lakes that are susceptible to hypolimnetic P release are especially vulnerable if they do not stratify stably during the summer; lake thermal stability is driven by lake morphometry and temperature. Shallow lakes in general develop a weak thermal stratification and are at greater risk to internal mixing. These lakes can also develop a warmer hypolimnetic temperature with an increased sediment oxygen demand that facilitates internal P release. Land use patterns of lake watersheds identify potential additions of external P. Lakes with greater areas of adjacent agriculture enhance dissolved and particulate $\mathrm{P}$ in surface runoff. Together these stressors identify factors posing a risk to lake water quality.

Lake managers need good estimates for potentially mobile sediment $\mathrm{P}$ and additional external inputs of $\mathrm{P}$ to a lake. The models developed here can inform regulatory agencies and lake associations in their best management practices with respect to epilimnetic $\mathrm{P}$. The regression tree can be used as an educational tool for landowners or stakeholders, as they can follow the paths and visually link the problems associated with eutrophication. This could be used as an outreach tool to educate landowners on practices they can adopt to keep water clean. The MLR models can be used to determine whether a lake is being adequately protected or if certain aspects have led to a higher vulnerability to water quality problems. Both the regression tree and MLR models can be used to 
identify drivers controlling P, potentially identifying a lake's chief pollution problem, whether from within the sediment, various climate/weather effects, exports of $\mathrm{P}$ to the lake, or a combination of these factors. The QR tool will allow stakeholders to evaluate the tradeoffs of various actions to build consensus on the most effective approaches for sustainably managing the watershed. Furthermore, the QR approach would be of broad interest to lake water quality managers who are involved in watershed land use planning, especially with respect to nutrient loading. In order to best manage a lake we suggest the application of all of these models to further lake and watershed understanding and protect aquatic resources. 


\section{REFERENCES}

Amirbahman, A., Pearce, A. R., Bouchard, R. J., Norton, S. A., \& Kahl, J. S. (2003). Relationship between hypolimnetic phosphorus and iron release from eleven lakes in Maine, USA. Biogeochemistry, 65(3), 369-386.

Barbiero, R. P., \& Welch, E. B. (1992). Contribution of benthic blue-green algal recruitment to lake populations and phosphorus translocation. Freshwater Biology, 27(2), 249-260.

Boström, B., Andersen, J. M., Fleischer, S., \& Jansson, M. (1988). Exchange of phosphorus across the sediment-water interface. Hydrobiologia, 170(1), 229-244.

Brett, M. T., \& Benjamin, M. M. (2008). A review and reassessment of lake phosphorus retention and the nutrient loading concept. Freshwater Biology, 53(1), 194-211.

Burnham K.P. \& Anderson D. R. (2002) Model Selection and Multimodel Inference: A Practical Information-Theoretic Approach, $2^{\text {nd }}$ edn. Springer-Verlag, New York, NY.

Cade, B. S., Terrell, J. W., \& Schroeder, R. L. (1999). Estimating effects of limiting factors with regression quantiles. Ecology, 80(1), 311-323.

Cade, B. S., \& Noon, B. R. (2003). A gentle introduction to quantile regression for ecologists. Frontiers in Ecology and the Environment, 1(8), 412-420.

Carey, C.C. and Rydin, E. (2011). Lake trophic status can be determined by the depth distribution of sediment phosphorus. Limnology and Oceanography, 56(6), pp.2051-2063.

Carey, C. C., Weathers, K. C., Ewing, H. A., Greer, M. L., \& Cottingham, K. L. (2014). Spatial and temporal variability in recruitment of the cyanobacterium Gloeotrichia echinulata in an oligotrophic lake. Freshwater Science, 33(2), 577-592.

Christophoridis, C., \& Fytianos, K. (2006). Conditions affecting the release of phosphorus from surface lake sediments. Journal of Environmental Quality, 35(4), 1181-1192.

Davis, R. B., Bailey, J. H., Scott, M., \& Norton, S. A. (1978). TB88: Descriptive and Comparative Studies of Maine Lakes.

De'ath, G. and Fabricius, K.E. (2000). Classification and regression trees: a powerful yet simple technique for ecological data analysis. Ecology, 81(11), pp.3178-3192. 
Dillon, P.J., \& Vollenweider, R.A. (1974). The application of the phosphorus loading concept to eutrophication research. Ottowa: National Research Council of Canada.

Dillon, P. J., \& Kirchner, W. B. (1975). The effects of geology and land use on the export of phosphorus from watersheds. Water Research, 9(2), 135-148.

Effler, S. W., Wagner, B. A., O'donnell, S. M., Matthews, D. A., O'donnell, D. M., Gelda, R.K.,... \& Cowen, E. A. (2004). An upwelling event at Onondaga Lake, NY: Characterization, impact and recurrence. Hydrobiologia, 511(1-3), 185-199.

Einsele, W. 1936. Uber die Beziehungen des Eisenkreislaufs zum Phosphatkreislauf im Eutrophen See. Archiv fur Hydrobiologie, 29, 664-686.

Filippelli, G. M. (2008). The Global Phosphorus Cycle: Past, Present, and Future. Elements, 4.2: 89-95.

Fisher, J., \& Acreman, M. C. (2004). Wetland nutrient removal: a review of the evidence. Hydrology and Earth System Sciences, 8(4), 673-685.

Fraterrigo, J. M., \& Downing, J. A. (2008). The influence of land use on lake nutrients varies with watershed transport capacity. Ecosystems, 11(7), 1021-1034.

Gächter, R., Meyer, J. S., Mares, A. (1988). Contribution of bacteria to release and fixation of phosphorus in lake sediments. Limnology and Oceanography, 33 (6 part 2), 1542-1558.

Gergel SE, Turner MG, Kratz TK. 1999. Dissolved organic carbon as an indicator of the scale of watershed influence on lakes and rivers. Ecol Appl 9:1377-90.

Gerten, D., \& Adrian, R. (2002). Effects of Climate Warming, North Atlantic Oscillation, and El Nino-Southern Oscillation on Thermal Conditions and Plankton Dynamics in Northern Hemispheric Lakes. The Scientific World JOURNAL, 2: 586-606.

Hondzo, M., \& Stefan, H. G. (1993). Regional water temperature characteristics of lakes subjected to climate change. Climatic Change, 24(3), 187-211.

Homyak, P. M., Sickman, J. O., \& Melack, J. M. (2014). Phosphorus in sediments of high-elevation lakes in the Sierra Nevada (California): implications for internal phosphorus loading. Aquatic Sciences, 76(4), 511-525.

Hongve D. (1972) En bunnhenter som er lett å lage. Fauna, 25, 281-283).

Hupfer, M. \& Lewandowski, J. (2008). Oxygen Controls the Phosphorus Release from Lake Sediments-a Long-Lasting Paradigm in Limnology. International Review of Hydrobiology, 93(4-5), 415-432. 
Huser, B.J., Egemose, S., Harper, H., Hupfer, M., Jensen, H., Pilgrim, K.M., Reitzel, K., Rydin, E. and Futter, M. (2016). Longevity and effectiveness of aluminum addition to reduce sediment phosphorus release and restore lake water quality. Water Research, 97, pp.122-132.

Huttula, T., Peltonen, A., Bilaletdin, A., \& Saura, M. (1992). The effects of climatic change on lake ice and water temperature. Aqua Fennica, 22, 129-129.

Jankowski, T., Livingstone, D. M., Bührer, H., Forster, R., \& Niederhauser, P. (2006). Consequences of the 2003 European heat wave for lake temperature profiles, thermal stability, and hypolimnetic oxygen depletion: Implications for a warmer world. Limnology and Oceanography, 51(2), 815-819.

Jensen, H. S., Reitzel, K., \& Egemose, S. (2015). Evaluation of aluminum treatment efficiency on water quality and internal phosphorus cycling in six Danish lakes. Hydrobiologia, 751(1), 189-199.

Jeppesen, E., Søndergaard, M., Jensen, J.P., Havens, K.E., Anneville, O., Carvalho, L., Coveney, M.F., Deneke, R., Dokulil, M.T., Foy, B.O.B. and Gerdeaux, D., 2005. Lake responses to reduced nutrient loading-an analysis of contemporary longterm data from 35 case studies. Freshwater Biology, 50(10), pp.1747-1771.

Kaiser, M. S., Speckman, P. L., \& Jones, J. R. (1994). Statistical models for limiting nutrient relations in inland waters. Journal of the American Statistical Association, 89(426), 410-423.

Kates, R. W., Clark, W. C., Corell, R., Hall, J. M., Jaeger, C. C., Lowe, I., ... \& Faucheux, S. (2001). Sustainability science.Science, 292(5517), 641-642.

Khoshmanesh, A., Hart, B., Dancan, A., Beckett, R. (2002). Luxury Uptake of Phosphorus by Sediment Bacteria. Water Research, 36.3: 774-78.

Koenker, R., \& Bassett Jr, G. (1978). Regression quantiles. Econometrica: Journal of the Econometric Society, 33-50.

Koenker, R. (1994). Confidence intervals for regression quantiles. In Asymptotic Statistics, (pp. 349-359). Physica, Heidelberg.

Koenker, R., Portnoy, S., Ng, P. T., Zeileis, A., Grosjean, P., \& Ripley, B. D. (2016). Package 'quantreg'. Version 5.26. R Foundation for Statistical Computing: Vienna, Austria.

Kopáček, J., Borovec, J., Hejzlar, J., Ulrich, K., Norton, S.A., Amirbahman, A. (2005) Aluminum control of phosphorus sorption by lake sediments. Environmental Science \& Technology, 39(22), 8784-8789. 
Kopáček, J., Hejzlar, J., Borovec, J., Porcal, P., \& Kotorova, I. (2000). Phosphorus inactivation by aluminum in the water column and sediments: Lowering of in-lake phosphorus availability in an watershedlake ecosystem.Limnology and Oceanography, 45(1), 212-225.

Lake, B.A., Coolidge, K.M., Norton, S.A., Amirbahman, A. (2007). Factors contributing to the internal loading of phosphorus from anoxic sediments in six Maine, USA, lakes. Science of the Total Environment, 373(2-3), 534-541.

McAvaney, B. J., Covey, C., Joussaume, S., Kattsov, V., Kitoh, A., Ogana, W., ... \& AchutaRao, K. (2001). Model evaluation. In Climate Change 2001: The scientific basis. Contribution of WG1 to the Third Assessment Report of the IPCC (TAR) (pp. 471-523). Cambridge University Press.

Monteith, D. T., Stoddard, J. L., Evans, C. D., De Wit, H. A., Forsius, M., Høgåsen, T., ... \&Keller, B. (2007). Dissolved organic carbon trends resulting from changes in atmospheric deposition chemistry. Nature, 450(7169), 537.

Mortimer, C.H. (1941). The exchange of dissolved substances between mud and water in lakes. Journal of Ecology, 29, 280-329.

North, R. P., North, R. L., Livingstone, D. M., Köster, O., \& Kipfer, R. (2014). Longterm changes in hypoxia and soluble reactive phosphorus in the hypolimnion of a large temperate lake: consequences of a climate regime shift. Global change biology, 20(3), 811-823.

Nürnberg, G. K. (1995). The anoxic factor, a quantitative measure of anoxia and fish species richness in central Ontario lakes.Transactions of the American Fisheries Society, 124(5), 677-686.

Nürnberg, G. K. (2009). Assessing internal phosphorus load-problems to be solved. Lake and Reservoir Management, 25(4), 419-432.

Osgood, R. (1988). Lake mixis and internal phosphorus dynamics. Arch. Hydrobiol. 113: (4) 629-638.

Petticrew, E. L., \& Arocena, J. M. (2001). Evaluation of iron-phosphate as a source of internal lake phosphorus loadings. Science of the total Environment, 266(1), 87 93.

Psenner, R., Pucsko, R., Sager, M. (1984). Die Fraktionierung organischer und Anorganischer Phosphorverbindungen von Sedimenten Versuch einer Definition ökologisch wichtiger Frakionen. Archive fur Hydrobiologie Supplement, 70, 11155. 
Quinn, G. P., \& Keough, M. J. (2002). Experimental design and data analysis for biologists. Cambridge University Press.

R Core Team (2015). R: A language and environment for statistical computing. R Foundation for Statistical Computing, Vienna, Austria. URL http://www.R project.org/.

Read, J. S., \& Muraoka, K. (2011). Lake Analyzer Ver. 3.3 User Manual. Global Lake Ecological Observatory Network.

Reinhardt, R.L., Norton, S.A., Handley, M., Amirbahman, A. (2004). Dynamics of P, Al, and Fe during high discharge episodic acidification at the Bear Brook watershed in Maine, U.S.A. Water, Air \& Soil Pollution: Focus, 4(2), 311-323.

Robertson, D., Imberger, J. (1994) Lake number, a quantitative indicator of mixing used to estimate changes in dissolved oxygen. International Review of Hydrobiology 79(2) 159-176.

Roy, S., Norton, S.A., Fernandez, I.J., Kahl, J.S. (1999). Linkages of P and Al export at high discharge at the Bear Brook watershed in Maine. Environmental Monitoring and Assessment, 55, 133-147.

Rydin, E., Huser, B., \& Welch, E. B. (2000). Amount of phosphorus inactivated by alum treatments in Washington lakes. Limnology and Oceanography, 45(1), 226-230.

Schmidt,W. (1928) Ueber Temperatur and Stabilitaetsverhaltnisse von Seen. Geographiska Annaler. 10, 145-177.

Solomon, C. T., Jones, S. E., Weidel, B. C., Buffam, I., Fork, M. L., Karlsson, J., ... \& Saros, J. E. (2015). Ecosystem consequences of changing inputs of terrestrial dissolved organic matter to lakes: current knowledge and future challenges. Ecosystems, 18(3), 376-389.

Sondergaard, M., Jensen, P. J., \& Jeppesen, E. (2001). Retention and internal loading of phosphorus in shallow, eutrophic lakes. The Scientific World Journal, 1, 427-442.

Søndergaard, M., Bjerring, R., \& Jeppesen, E. (2013). Persistent internal phosphorus loading during summer in shallow eutrophic lakes. Hydrobiologia,710(1), 95-107.

Spears, B. M., May, L. (2015). Long-term Homeostasis of Filterable Un-reactive Phosphorus in a Shallow Eutrophic Lake following a Significant Reduction in Catchment Load. Science Direct: Geoderma, 257-258, 78-85.

Stumm, W., \& Morgan, J. J. (1996). Aquatic Chemistry: Chemical Equilibria and Rates in Natural Waters \{Environmental Science and Technology\}. Wiley. 
Therneau, T., Atkinson, B., \& Ripley, B. (2016). rpart: Recursive Partitioning and Regression Trees. 2015. R package version 4.1-10.

Vollenweider, R. A. (1976). Advances in defining critical loading levels for phosphorus in lake eutrophication. Memorie dell'Istituto Italiano di Idrobiologia, Dott. Marco de Marchi Verbania Pallanza.

Welch, E. B., \& Cooke, G. D. (1999). Effectiveness and longevity of phosphorus Inactivation with alum. Lake and Reservoir management, 15(1), 5-27.

Wetzel, R.G. (2001). Limnology: lake and river ecosystems. $3^{\text {rd }}$ ed. San Diego. Academic Press.

Wilhelm, S., \& Adrian, R. (2008). Impact of summer warming on the thermal characteristics of a polymictic lake and consequences for oxygen, nutrients and phytoplankton. Freshwater Biology, 53(2), 226-237.

Xu, Y., Schroth, A. W., Isles, P. D., \& Rizzo, D. M. (2015). Quantile regression improves models of lake eutrophication with implications for ecosystem-specific management. Freshwater biology, 60(9), 1841-1853. 


\section{APPENDIX A: MIDAS IDENTIFICATION}

Table A1: Midas Identification. Organized by lakes from 2015, 2016, DEP, and LEA.

\begin{tabular}{|c|c|}
\hline Lake & Midas \\
\hline 2015 & - \\
\hline Auburn & 3748 \\
\hline China & 5448 \\
\hline Clearwater & 5190 \\
\hline Damariscotta & 5400 \\
\hline East & 5349 \\
\hline Embden & 78 \\
\hline Great & 5274 \\
\hline Hopkins & 4538 \\
\hline Long & 5272 \\
\hline McGrath & 5348 \\
\hline Meddybemps & 177 \\
\hline Messalonskee & 5280 \\
\hline Mousam & 3838 \\
\hline North & 5344 \\
\hline Pleasant & 224 \\
\hline Pleasant & 3446 \\
\hline Sabattus & 3796 \\
\hline Salmon & 5352 \\
\hline Square & 3916 \\
\hline Taylor & 3750 \\
\hline Thompson & 3444 \\
\hline Tunk & 4434 \\
\hline Unity & 5172 \\
\hline Webber & 5408 \\
\hline 2016 & - \\
\hline Abrams & 4444 \\
\hline David & 5666 \\
\hline Echo & 5814 \\
\hline Flying & 5182 \\
\hline Georges & 4406 \\
\hline Kimball & 5330 \\
\hline Lower Range & 5664 \\
\hline Lovejoy & 3760 \\
\hline Middle Range & 3762 \\
\hline Minnehonk & 5812 \\
\hline Molasses & 4448 \\
\hline
\end{tabular}

\begin{tabular}{|c|c|}
\hline Lake & Midas \\
\hline Parker & 5186 \\
\hline Pickerel & 3826 \\
\hline Pocasett & 3824 \\
\hline Scammon & 4446 \\
\hline Upper Range & 3688 \\
\hline Webb & 4346 \\
\hline Whitter & 5184 \\
\hline DEP & - \\
\hline Alamoosook & 4336 \\
\hline Anasagunticook & 3604 \\
\hline Baskahegan & 1078 \\
\hline Bay of Naples & 9685 \\
\hline Biscay & 5710 \\
\hline Brackett & 1068 \\
\hline Branch & 4328 \\
\hline $\begin{array}{l}\text { Branch (Upper } \\
\text { Middle) }\end{array}$ & 4492 \\
\hline Bubble & 4452 \\
\hline Cedar & 2004 \\
\hline Center & 760 \\
\hline Chickawaukie & 4822 \\
\hline China & 5448 \\
\hline Cobbosseecontee & 5236 \\
\hline Cochnewagon & 3814 \\
\hline Cold Rain & 3376 \\
\hline Cold Stream & 2146 \\
\hline Crystal & 3452 \\
\hline Crystal (Beals) & 3626 \\
\hline Damariscotta & 5400 \\
\hline Dexter & 3830 \\
\hline Dyer Long & 5386 \\
\hline Eagle & 4606 \\
\hline East & 5349 \\
\hline Echo & 4624 \\
\hline Echo (Crotched) & 5814 \\
\hline Fish & 4802 \\
\hline Flanders & 4388 \\
\hline Gassabias & 4782 \\
\hline
\end{tabular}


Table A1: Continued

\begin{tabular}{|c|c|c|c|}
\hline Lake & Midas & Lake & Midas \\
\hline Grand (East) & 1070 & Pleasant River & 1210 \\
\hline Grand (West) & 1150 & Pushaw & 80 \\
\hline Hadlock (Lower) & 4610 & Pushaw (Little) & 2156 \\
\hline Hadlock (Upper) & 4612 & Raymond & 3690 \\
\hline Halls & 3780 & Rocky & 4330 \\
\hline Hermon & 2286 & Round & 4620 \\
\hline Highland & 3454 & Round (Little) & 4618 \\
\hline Hobbs & 4806 & Salmon & 5352 \\
\hline Hodgdon & 4628 & Sandy (Freedom) & 5174 \\
\hline Horseshoe & 4788 & Sawyer & 386 \\
\hline Jacob Buck & 4322 & Seal Cove & 4630 \\
\hline Jo-Mary (Upper) & 243 & Seboeis & 954 \\
\hline Jordan & 4608 & Sennebec & 5682 \\
\hline Kingsbury & 262 & Sheepscot & 4896 \\
\hline Knight & 3884 & Somes & 4614 \\
\hline Lake George & 2608 & Spednik & 121 \\
\hline Lermond & 4800 & Threemile & 5416 \\
\hline Lobster & 2948 & Toddy & 5490 \\
\hline Long & 447 & Togus & 9931 \\
\hline Long & 4316 & Unity & 5172 \\
\hline Long & 5780 & Washington & 4894 \\
\hline Long (Great) & 4622 & Webb (Weld) & 3672 \\
\hline Mattakeunk & 2242 & Webber & 4857 \\
\hline McGrath & 5348 & Webber & 5408 \\
\hline Meddybemps & 177 & Wesserunsett & 70 \\
\hline Megunticook & 4852 & Wilson & 3682 \\
\hline Messalonskee & 5280 & Wilson & 3920 \\
\hline Millinocket & 2020 & Wilson (Lower) & 342 \\
\hline Molunkus & 3038 & Wilson (Upper) & 410 \\
\hline Moose & 2590 & Woodbury & 5240 \\
\hline Musquash & 1088 & LEA & - \\
\hline Nequasset & 5222 & Back Main Basin & 3199 \\
\hline Nicatous & 4766 & Bear Pond Main Basin & 3420 \\
\hline North & 5344 & Beaver Pond Main & 5582 \\
\hline North & 5690 & Basin & \\
\hline Ossipee (Little) & 5024 & $\begin{array}{l}\text { Brandy Pond Mrain } \\
\text { Basin }\end{array}$ & 9685 \\
\hline Parker & 3388 & Crystal Lake Main & 3452 \\
\hline Parks & 4272 & Granger Pond Main & 3126 \\
\hline Pattee & 5458 & Basin & נ120 \\
\hline Pease & 5198 & Hancock Pond & 3132 \\
\hline Pennesseewassee & 3434 & Highland Main Basin & 3454 \\
\hline
\end{tabular}


Table A1: Continued

\begin{tabular}{|ll|}
\hline Lake & Midas \\
\hline Highland NE. Basin & 3454 \\
Island Pond Main & 3448 \\
Basin & 3416 \\
Keoka Main Basin & 3232 \\
Keyes Main Basin & 3424 \\
Little Moose Main & 5780 \\
Basin & 5780 \\
Long Basin 1 & 5780 \\
Long Basin 1 (re-test) & 5780 \\
Long Basin 2 & 5780 \\
Long Basin 3 & 3418 \\
Long East Cove & 3134 \\
McWain Main Basin & 3134 \\
Moose Pond Main & 3134 \\
Basin & 3374 \\
Moose Pond N. Basin & 3130 \\
Moose Pond S. Basin & 3234 \\
Peabody Main Basin & 3382 \\
Sand Pond Main Basin & 3456 \\
Stearns Main & \\
Trickey Pond & Woods Pond
\end{tabular}




\section{APPENDIX B: SEDIMENT AND WATER CHEMISTRY DATA}

Table B1: Sediment Chemistry from the Surface $(0-2 \mathrm{~cm})$. Data from the surface short cores taken from the 2015, 2016, DEP, and the LEA.

\begin{tabular}{|c|c|c|c|c|c|c|c|c|c|c|c|c|c|c|}
\hline Midas & $\begin{array}{c}\text { Sample } \\
\text { Date }\end{array}$ & $\%$ LOI & $\begin{array}{c}\text { BD- } \\
\text { Al, } \\
\mu \mathrm{mol} / \mathrm{g}\end{array}$ & $\begin{array}{c}\text { NaOH- } \\
\text { Al, } \\
\mu \mathrm{mol} / \mathrm{g}\end{array}$ & $\begin{array}{c}\begin{array}{c}\text { HCl- } \\
\text { Al, } \\
\mu \mathrm{mol} / \mathrm{g}\end{array} \\
\end{array}$ & $\begin{array}{c}\text { BD- } \\
\text { Fe, } \\
\mu \mathrm{mol} / \mathrm{g}\end{array}$ & $\begin{array}{c}\text { NaOH- } \\
\text { Fe, } \\
\mu \mathrm{mol} / \mathrm{g}\end{array}$ & $\begin{array}{c}\begin{array}{c}\mathrm{HCl}- \\
\mathrm{Fe}, \\
\mu \mathrm{mol} / \mathrm{g}\end{array} \\
\end{array}$ & $\begin{array}{c}\text { BD- } \\
\text { P, } \\
\mu \mathrm{mol} / \mathrm{g}\end{array}$ & $\begin{array}{c}\mathrm{NaOH}- \\
\mathrm{P}, \\
\mu \mathrm{mol} / \mathrm{g}\end{array}$ & $\begin{array}{c}\text { NaOH- } \\
\text { rP, } \\
\mu \mathrm{mol} / \mathrm{g}\end{array}$ & $\begin{array}{c}\text { NaOH- } \\
\text { nrP, } \\
\mu \mathrm{mol} / \mathrm{g}\end{array}$ & $\begin{array}{c}\mathrm{NaOH}- \\
\text { rP:P }\end{array}$ & $\begin{array}{c}\text { HCl- } \\
\mathrm{P}, \\
\mu \mathrm{mol} / \mathrm{g} \\
\end{array}$ \\
\hline \multicolumn{15}{|l|}{2015} \\
\hline 3748 & $6 / 26 / 15$ & 12.6 & 3.2 & 120.5 & 326.3 & 92.8 & 23.2 & 263.1 & 15.4 & 18.5 & NA & NA & NA & 9.1 \\
\hline 5448 & $6 / 24 / 15$ & 23.1 & 1.9 & 86.6 & 289.1 & 210.4 & 41.0 & 871.5 & 53.1 & 136.2 & NA & NA & NA & 28.6 \\
\hline 5190 & $7 / 8 / 15$ & 22.3 & 5.0 & 370.5 & 236.8 & 74.6 & 63.5 & 81.8 & 3.0 & 44.0 & NA & NA & NA & 2.3 \\
\hline 5400 & $7 / 13 / 15$ & 17.9 & 2.5 & 382.3 & 328.0 & 132.4 & 147.1 & 149.8 & 5.0 & 44.5 & NA & NA & NA & 2.6 \\
\hline 5349 & $6 / 25 / 15$ & 16.7 & 3.8 & 151.6 & 133.6 & 83.2 & 28.8 & 86.0 & 6.2 & 17.5 & NA & NA & NA & 1.2 \\
\hline 78 & $7 / 9 / 15$ & 30.8 & 8.4 & 272.5 & 137.1 & 275.2 & 88.0 & 67.4 & 2.8 & 35.8 & NA & NA & NA & 1.8 \\
\hline 5274 & $7 / 6 / 15$ & 25.4 & 4.5 & 216.8 & 197.0 & 124.2 & 48.2 & 117.1 & 7.7 & 46.5 & NA & NA & NA & 4.2 \\
\hline 4538 & $7 / 10 / 15$ & 32.8 & 15.9 & 416.7 & 189.1 & 48.9 & 33.9 & 29.8 & 1.9 & 33.2 & NA & NA & NA & 1.6 \\
\hline 5272 & $7 / 6 / 15$ & 30.6 & 6.1 & 313.1 & 267.9 & 146.3 & 61.5 & 168.0 & 9.7 & 52.6 & NA & NA & NA & 3.6 \\
\hline 5348 & $7 / 2 / 15$ & 23.8 & 6.4 & 255.8 & 217.3 & 101.5 & 40.0 & 107.8 & 5.4 & 33.1 & NA & NA & NA & 5.0 \\
\hline 177 & $6 / 30 / 15$ & 18.1 & 2.1 & 112.2 & 118.1 & 153.9 & 58.7 & 564.7 & 3.0 & 41.5 & NA & NA & NA & 4.7 \\
\hline 5280 & $7 / 2 / 15$ & 32.7 & 22.3 & 325.8 & 160.2 & 903.4 & 147.7 & 216.5 & 82.5 & 64.6 & NA & NA & NA & 2.6 \\
\hline 3838 & $6 / 29 / 15$ & 42.6 & 136.7 & 288.3 & 69.6 & 1125.8 & 144.8 & 105.8 & 42.3 & 41.2 & NA & NA & NA & 1.3 \\
\hline 5344 & $6 / 25 / 15$ & 18.6 & 2.9 & 177.6 & 104.6 & 66.5 & 39.0 & 49.1 & 2.8 & 21.9 & NA & NA & NA & 2.6 \\
\hline 224 & $7 / 8 / 15$ & 16.9 & 9.0 & 224.9 & 254.2 & 268.5 & 54.5 & 153.1 & 5.8 & 42.7 & NA & NA & NA & 2.7 \\
\hline 3446 & $7 / 7 / 15$ & 24.8 & 9.1 & 202.8 & 127.9 & 31.9 & 15.2 & 51.1 & 2.8 & 25.4 & NA & NA & NA & 1.7 \\
\hline 3796 & $6 / 26 / 15$ & 14.3 & 11.1 & 159.9 & 272.2 & 179.7 & 25.3 & 223.8 & 11.8 & 20.7 & NA & NA & NA & 1.4 \\
\hline 5352 & $7 / 2 / 15$ & 18.8 & 2.8 & 140.8 & 161.1 & 137.8 & 20.8 & 158.3 & 25.2 & 23.2 & NA & NA & NA & 5.3 \\
\hline 3916 & $6 / 29 / 15$ & 47.4 & 12.7 & 159.0 & 111.3 & 196.6 & 29.8 & 61.5 & 7.4 & 27.5 & NA & NA & NA & 1.6 \\
\hline 3750 & $7 / 9 / 15$ & 19.6 & 4.2 & 207.0 & 256.6 & 134.5 & 37.0 & 175.3 & 7.4 & 29.3 & NA & NA & NA & 7.5 \\
\hline
\end{tabular}


Table B1: Continued

\begin{tabular}{|c|c|c|c|c|c|c|c|c|c|c|c|c|c|c|}
\hline Midas & $\begin{array}{c}\text { Sample } \\
\text { Date }\end{array}$ & $\%$ LOI & $\begin{array}{c}\text { BD- } \\
\text { Al, } \\
\mu \mathrm{mol} / \mathrm{g}\end{array}$ & $\begin{array}{c}\mathrm{NaOH}- \\
\mathrm{Al}, \\
\mu \mathrm{mol} / \mathrm{g}\end{array}$ & $\begin{array}{c}\text { HCl- } \\
\text { Al, } \\
\mu \mathrm{mol} / \mathrm{g}\end{array}$ & $\begin{array}{c}\text { BD- } \\
\text { Fe, } \\
\mu \mathrm{mol} / \mathrm{g}\end{array}$ & $\begin{array}{c}\mathrm{NaOH}- \\
\mathrm{Fe}, \\
\mu \mathrm{mol} / \mathrm{g}\end{array}$ & $\begin{array}{c}\mathrm{HCl}- \\
\mathrm{Fe}, \\
\mu \mathrm{mol} / \mathrm{g}\end{array}$ & $\begin{array}{c}\text { BD- } \\
\text { P, } \\
\mu \mathrm{mol} / \mathrm{g}\end{array}$ & $\begin{array}{c}\text { NaOH- } \\
\text { P, } \\
\mu \mathrm{mol} / \mathrm{g}\end{array}$ & $\begin{array}{l}\mathrm{NaOH}- \\
\mathrm{rP}, \\
\mu \mathrm{mol} / \mathrm{g}\end{array}$ & $\begin{array}{l}\mathrm{NaOH}- \\
\mathrm{nrP}, \\
\mu \mathrm{mol} / \mathrm{g}\end{array}$ & $\begin{array}{c}\mathrm{NaOH}- \\
\text { rP:P }\end{array}$ & $\begin{array}{c}\text { HCl- } \\
P, \\
\mu \mathrm{mol} / \mathrm{g}\end{array}$ \\
\hline 3444 & $7 / 7 / 15$ & 27.6 & 20.0 & 374.8 & 129.5 & 356.0 & 53.8 & 134.4 & 5.7 & 49.6 & NA & NA & NA & 1.4 \\
\hline 4434 & $6 / 30 / 15$ & 11.2 & 2.9 & 147.2 & 432.4 & 510.6 & 127.3 & 545.6 & 1.8 & 39.4 & NA & NA & NA & 0.6 \\
\hline 5172 & $7 / 1 / 15$ & 15.3 & 2.5 & 152.6 & 150.2 & 95.6 & 23.0 & 141.8 & 13.1 & 29.3 & NA & NA & NA & 4.8 \\
\hline 5408 & $6 / 24 / 15$ & 15.0 & 3.9 & 152.4 & 252.2 & 248.2 & 9.7 & 268.4 & 46.7 & 41.4 & NA & NA & NA & 6.0 \\
\hline \multicolumn{15}{|l|}{2016} \\
\hline 4444 & $6 / 24 / 16$ & 11.9 & 1.7 & 361.9 & 161.4 & 109.7 & 69.8 & 95.9 & 10.6 & 24.2 & NA & NA & NA & 7.6 \\
\hline 5666 & $6 / 28 / 16$ & 33.4 & 3.7 & 308.1 & 141.8 & 97.0 & 39.0 & 65.3 & 5.5 & 41.8 & NA & NA & NA & 1.6 \\
\hline 5814 & $6 / 23 / 16$ & 26.1 & 3.7 & 426.6 & 180.8 & 149.6 & 96.4 & 91.7 & 7.8 & 52.6 & NA & NA & NA & 2.6 \\
\hline 5182 & $6 / 23 / 16$ & 21.7 & 9.4 & 520.0 & 227.3 & 281.1 & 158.7 & 217.6 & 11.5 & 46.7 & NA & NA & NA & 2.9 \\
\hline 4406 & $6 / 27 / 16$ & 14.9 & 2.7 & 348.8 & 143.0 & 124.2 & 67.5 & 101.7 & 13.7 & 18.6 & NA & NA & NA & 4.6 \\
\hline 5330 & $6 / 29 / 16$ & 24.3 & 5.0 & 436.2 & 151.9 & 64.1 & 71.8 & 65.1 & 4.5 & 31.7 & NA & NA & NA & 1.7 \\
\hline 5664 & $6 / 30 / 16$ & 22.2 & 1.7 & 280.3 & 235.1 & 134.7 & 53.4 & 118.6 & 4.9 & 32.6 & NA & NA & NA & 3.4 \\
\hline 3760 & $6 / 22 / 16$ & 29.7 & 2.6 & 374.0 & 172.1 & 103.4 & 54.6 & 94.9 & 4.9 & 41.4 & NA & NA & NA & 2.2 \\
\hline 3762 & $6 / 22 / 16$ & 25.1 & 2.7 & 433.6 & 196.9 & 107.9 & 61.0 & 88.7 & 6.2 & 52.2 & NA & NA & NA & 3.6 \\
\hline 5812 & $6 / 29 / 16$ & 29.3 & 16.9 & 502.3 & 185.8 & 450.5 & 233.3 & 273.0 & 31.9 & 53.0 & NA & NA & NA & 3.9 \\
\hline 4448 & $6 / 24 / 16$ & 6.7 & 1.7 & 273.1 & 76.6 & 22.1 & 51.2 & 38.9 & 1.4 & 17.4 & NA & NA & NA & 2.8 \\
\hline 5186 & $6 / 29 / 16$ & 23.4 & 1.6 & 306.8 & 174.7 & 61.3 & 44.1 & 80.3 & 2.8 & 35.9 & NA & NA & NA & 2.7 \\
\hline 3826 & $6 / 30 / 16$ & 33.7 & 3.9 & 163.5 & 80.9 & 103.2 & 20.8 & 41.8 & 5.2 & 21.5 & NA & NA & NA & 0.2 \\
\hline 3824 & $6 / 30 / 16$ & 12.4 & 1.2 & 184.2 & 213.1 & 122.8 & 43.9 & 116.9 & 4.3 & 23.3 & NA & NA & NA & 6.5 \\
\hline 4446 & $6 / 27 / 16$ & 58.9 & 6.1 & 192.6 & 36.6 & 109.2 & 20.3 & 24.1 & 7.2 & 25.0 & NA & NA & NA & 0.8 \\
\hline 3688 & $6 / 23 / 16$ & 30.4 & 5.0 & 252.9 & 131.1 & 67.6 & 27.8 & 46.5 & 7.7 & 36.3 & NA & NA & NA & 1.4 \\
\hline 4346 & $6 / 24 / 16$ & 14.9 & 2.7 & 355.8 & 110.8 & 79.0 & 67.5 & 62.3 & 2.8 & 29.4 & NA & NA & NA & 5.0 \\
\hline 5184 & $6 / 28 / 16$ & 51.2 & 4.6 & 207.6 & 71.8 & 30.4 & 15.4 & 27.2 & 9.4 & 35.4 & NA & NA & NA & 0.7 \\
\hline \multicolumn{15}{|l|}{ DEP } \\
\hline 70 & $8 / 9 / 11$ & 24.4 & 3.2 & 312.0 & 149.0 & 228.0 & 145.8 & 141.0 & 6.1 & 44.0 & 20.0 & 23.6 & 0.5 & 2.8 \\
\hline
\end{tabular}


Table B1: Continued

\begin{tabular}{|c|c|c|c|c|c|c|c|c|c|c|c|c|c|c|}
\hline Midas & $\begin{array}{c}\text { Sample } \\
\text { Date }\end{array}$ & $\%$ LOI & $\begin{array}{c}\text { BD- } \\
\text { Al, } \\
\mu \mathrm{mol} / \mathrm{g}\end{array}$ & $\begin{array}{c}\mathrm{NaOH}- \\
\mathrm{Al}, \\
\mu \mathrm{mol} / \mathrm{g}\end{array}$ & $\begin{array}{c}\text { HCl- } \\
\text { Al, } \\
\mu \mathrm{mol} / \mathrm{g}\end{array}$ & $\begin{array}{c}\text { BD- } \\
\text { Fe, } \\
\mu \mathrm{mol} / \mathrm{g}\end{array}$ & $\begin{array}{c}\text { NaOH- } \\
\text { Fe, } \\
\mu \mathrm{mol} / \mathrm{g}\end{array}$ & $\begin{array}{c}\text { HCl- } \\
\text { Fe, } \\
\mu \mathrm{mol} / \mathrm{g}\end{array}$ & $\begin{array}{c}\text { BD- } \\
\text { P, } \\
\mu \mathrm{mol} / \mathrm{g}\end{array}$ & $\begin{array}{c}\text { NaOH- } \\
\text { P, } \\
\mu \mathrm{mol} / \mathrm{g}\end{array}$ & $\begin{array}{c}\text { NaOH- } \\
\text { rP, } \\
\mu \mathrm{mol} / \mathrm{g}\end{array}$ & $\begin{array}{c}\text { NaOH- } \\
\text { nrP, } \\
\mu \mathrm{mol} / \mathrm{g}\end{array}$ & $\begin{array}{c}\text { NaOH- } \\
\text { rP:P }\end{array}$ & $\begin{array}{c}\text { HCl- } \\
\text { P, } \\
\mu \mathrm{mol} / \mathrm{g} \\
\end{array}$ \\
\hline 80 & $8 / 24 / 11$ & 17.4 & 1.6 & 222.0 & 141.0 & 123.3 & 70.9 & 90.4 & 4.1 & 35.7 & 18.6 & 17.1 & 0.5 & 3.8 \\
\hline 121 & $8 / 24 / 11$ & 26.5 & 3.1 & 308.0 & 144.0 & 61.5 & 59.6 & 71.9 & 2.0 & 43.3 & 20.1 & 23.2 & 0.5 & 2.8 \\
\hline 177 & $9 / 23 / 10$ & 20.6 & 2.5 & 269.0 & 200.0 & 399.0 & 180.6 & 227.6 & 6.6 & 81.3 & 51.2 & 30.0 & 0.6 & 3.3 \\
\hline 243 & $9 / 1 / 11$ & 24.8 & 5.3 & 454.0 & 110.0 & 170.0 & 140.4 & 54.0 & 0.0 & 43.0 & 12.0 & 31.2 & 0.3 & 1.5 \\
\hline 262 & $8 / 30 / 10$ & 18.6 & 7.3 & 676.0 & 239.0 & 73.0 & 140.0 & 91.2 & 3.0 & 51.5 & 20.5 & 31.0 & 0.4 & 2.7 \\
\hline 342 & $9 / 1 / 11$ & 20.3 & 3.5 & 345.0 & 243.0 & 141.0 & 103.3 & 113.0 & 5.1 & 34.0 & 16.0 & 18.3 & 0.5 & 2.5 \\
\hline 386 & $8 / 23 / 11$ & 17.2 & 3.7 & 327.0 & 109.0 & 111.6 & 65.9 & 63.0 & 2.2 & 20.9 & 7.4 & 13.6 & 0.4 & 0.5 \\
\hline 410 & $9 / 1 / 11$ & 15.7 & 2.9 & 208.0 & 344.0 & 279.4 & 133.1 & 554.0 & 3.8 & 29.0 & 15.0 & 14.0 & 0.5 & 2.4 \\
\hline 447 & $9 / 23 / 12$ & 26.5 & 2.1 & 123.0 & 95.0 & 32.0 & 15.9 & 44.5 & 1.7 & 11.1 & 2.5 & 8.6 & 0.2 & 1.0 \\
\hline 760 & $8 / 30 / 10$ & 35.7 & 5.2 & 118.0 & 90.7 & 68.0 & 24.1 & 53.0 & 8.0 & 10.3 & 4.1 & 6.2 & 0.4 & 2.8 \\
\hline 954 & $8 / 23 / 10$ & 30.9 & 6.0 & 361.0 & 59.1 & 141.0 & 140.0 & 25.2 & 1.6 & 27.0 & 12.5 & 14.5 & 0.5 & 1.4 \\
\hline 1068 & $8 / 24 / 11$ & 7.8 & 1.3 & 122.0 & 81.0 & 52.0 & 25.1 & 38.0 & 1.3 & 15.0 & 4.0 & 10.9 & 0.3 & 5.4 \\
\hline 1070 & $8 / 24 / 11$ & 21.3 & 8.5 & 383.0 & 115.0 & 358.8 & 101.7 & 63.6 & 8.2 & 49.0 & 21.6 & 27.4 & 0.4 & 2.8 \\
\hline 1078 & $8 / 22 / 11$ & 20.6 & 2.0 & 217.0 & 164.0 & 134.5 & 93.4 & 110.4 & 0.9 & 37.1 & 17.6 & 19.5 & 0.5 & 3.5 \\
\hline 1088 & $8 / 22 / 11$ & 27.6 & 3.8 & 392.0 & 109.0 & 96.0 & 126.3 & 43.0 & 0.0 & 38.0 & 15.0 & 23.1 & 0.4 & 1.5 \\
\hline 1150 & $9 / 23 / 10$ & 21.3 & 3.2 & 181.0 & 86.0 & 318.3 & 61.8 & 70.0 & 2.9 & 28.5 & 13.3 & 15.3 & 0.5 & 1.4 \\
\hline 1210 & $8 / 25 / 10$ & 30.1 & 16.5 & 557.0 & 69.6 & 321.0 & 150.0 & 42.1 & 6.5 & 40.2 & 19.7 & 20.5 & 0.5 & 1.4 \\
\hline 2004 & $8 / 23 / 10$ & 25.5 & 6.6 & 883.0 & 136.0 & 75.6 & 134.0 & 32.9 & 1.4 & 51.4 & 19.8 & 31.6 & 0.4 & 3.3 \\
\hline 2020 & $8 / 15 / 11$ & 20.7 & 3.6 & 170.0 & 185.0 & 260.1 & 79.3 & 215.1 & 3.2 & 31.0 & 19.9 & 11.2 & 0.6 & 3.4 \\
\hline 2146 & $8 / 17 / 11$ & 25.3 & 2.9 & 180.0 & 100.0 & 88.0 & 47.1 & 28.2 & 1.8 & 21.6 & 8.7 & 12.9 & 0.4 & 1.2 \\
\hline 2156 & $8 / 24 / 11$ & 30.0 & 1.3 & 114.0 & 137.0 & 66.0 & 34.4 & 95.0 & 5.8 & 18.0 & 8.0 & 10.1 & 0.4 & 5.3 \\
\hline 2242 & $8 / 17 / 11$ & 33.0 & 1.0 & 150.0 & 97.0 & 28.8 & 16.3 & 47.4 & 6.6 & 13.6 & 4.1 & 9.5 & 0.3 & 1.7 \\
\hline 2286 & $9 / 2 / 10$ & 55.4 & 7.7 & 148.0 & 151.0 & 152.0 & 13.6 & 130.0 & 13.8 & 19.7 & 8.5 & 11.2 & 0.4 & 9.7 \\
\hline 2590 & $8 / 30 / 10$ & 20.9 & 12.2 & 288.0 & 90.7 & 130.0 & 67.1 & 58.3 & 5.3 & 28.4 & 13.7 & 14.7 & 0.5 & 1.7 \\
\hline 2608 & $8 / 30 / 10$ & 23.1 & 8.2 & 659.0 & 202.8 & 165.0 & 120.0 & 86.0 & 8.9 & 51.9 & 25.7 & 26.3 & 0.5 & 4.2 \\
\hline
\end{tabular}


Table B1: Continued

\begin{tabular}{|c|c|c|c|c|c|c|c|c|c|c|c|c|c|c|}
\hline Midas & $\begin{array}{c}\text { Sample } \\
\text { Date }\end{array}$ & $\%$ LOI & $\begin{array}{c}\text { BD- } \\
\text { Al, } \\
\mu \mathrm{mol} / \mathrm{g}\end{array}$ & $\begin{array}{c}\mathrm{NaOH}- \\
\mathrm{Al}, \\
\mu \mathrm{mol} / \mathrm{g}\end{array}$ & $\begin{array}{c}\text { HCl- } \\
\text { Al, } \\
\mu \mathrm{mol} / \mathrm{g}\end{array}$ & $\begin{array}{c}\text { BD- } \\
\text { Fe, } \\
\mu \mathrm{mol} / \mathrm{g}\end{array}$ & $\begin{array}{c}\text { NaOH- } \\
\text { Fe, } \\
\mu \mathrm{mol} / \mathrm{g}\end{array}$ & $\begin{array}{c}\text { HCl- } \\
\text { Fe, } \\
\mu \mathrm{mol} / \mathrm{g}\end{array}$ & $\begin{array}{c}\text { BD- } \\
\text { P, } \\
\mu \mathrm{mol} / \mathrm{g}\end{array}$ & $\begin{array}{c}\text { NaOH- } \\
\text { P, } \\
\mu \mathrm{mol} / \mathrm{g}\end{array}$ & $\begin{array}{c}\text { NaOH- } \\
\text { rP, } \\
\mu \mathrm{mol} / \mathrm{g}\end{array}$ & $\begin{array}{c}\text { NaOH- } \\
\text { nrP, } \\
\mu \mathrm{mol} / \mathrm{g}\end{array}$ & $\begin{array}{c}\text { NaOH- } \\
\text { rP:P }\end{array}$ & $\begin{array}{c}\text { HCl- } \\
\mathrm{P}, \\
\mu \mathrm{mol} / \mathrm{g}\end{array}$ \\
\hline 2948 & $8 / 30 / 10$ & 13.0 & 16.1 & 242.0 & 143.0 & 342.0 & 90.0 & 120.0 & 5.3 & 27.1 & 15.5 & 11.5 & 0.6 & 12.3 \\
\hline 3038 & $8 / 24 / 11$ & 8.1 & 1.1 & 160.0 & 74.0 & 41.8 & 48.5 & 46.3 & 0.4 & 20.5 & 11.8 & 8.7 & 0.6 & 3.6 \\
\hline 3376 & $8 / 25 / 11$ & 33.4 & 3.0 & 199.0 & 47.0 & 26.5 & 12.3 & 15.2 & 4.6 & 29.6 & 9.6 & 20.0 & 0.3 & 1.4 \\
\hline 3388 & $9 / 7 / 10$ & 19.3 & 5.5 & 227.0 & 118.0 & 88.5 & 37.7 & 54.0 & 3.4 & 29.8 & 10.4 & 19.4 & 0.4 & 6.6 \\
\hline 3434 & $9 / 1 / 10$ & 30.5 & 9.0 & 521.0 & 185.0 & 122.0 & 82.6 & 81.7 & 8.8 & 48.7 & 20.4 & 28.3 & 0.4 & 5.0 \\
\hline 3452 & $8 / 31 / 10$ & 20.7 & 9.6 & 562.0 & 224.0 & 202.0 & 105.0 & 87.3 & 2.9 & 51.8 & 28.7 & 23.2 & 0.6 & 7.4 \\
\hline 3454 & $8 / 16 / 11$ & 30.5 & 3.5 & 512.0 & NA & 70.4 & 64.3 & NA & 0.0 & 65.1 & 32.2 & 32.9 & 0.5 & NA \\
\hline 3604 & $8 / 18 / 11$ & 19.1 & 5.7 & 269.0 & 186.0 & 82.8 & 41.6 & 75.5 & 2.9 & 31.4 & 16.2 & 15.3 & 0.5 & 5.2 \\
\hline 3626 & $9 / 1 / 10$ & 26.1 & 19.7 & 355.0 & 172.0 & 117.0 & 104.0 & 156.0 & 13.1 & 21.0 & 10.3 & 10.6 & 0.5 & 9.0 \\
\hline 3672 & $8 / 10 / 11$ & 19.5 & 4.8 & 323.0 & 236.0 & 157.7 & 89.2 & 173.5 & 1.9 & 37.9 & 22.1 & 15.7 & 0.6 & 2.8 \\
\hline 3682 & $8 / 10 / 11$ & 23.0 & 7.2 & 425.0 & 210.0 & 321.4 & 134.7 & 219.6 & 1.3 & 40.2 & 23.0 & 17.2 & 0.6 & 1.4 \\
\hline 3690 & $8 / 31 / 10$ & 27.5 & 7.1 & 366.0 & 123.0 & 83.8 & 41.1 & 64.0 & 10.8 & 42.7 & 14.8 & 27.9 & 0.4 & 4.7 \\
\hline 3696 & $8 / 31 / 11$ & 20.2 & 2.8 & 243.0 & 124.0 & 47.2 & 29.7 & 59.9 & 3.1 & 35.4 & 16.8 & 18.6 & 0.5 & 6.6 \\
\hline 3712 & 8/19/10 & 31.8 & 12.9 & 422.0 & 111.0 & 205.0 & 82.3 & 67.7 & 7.4 & 49.5 & 24.5 & 25.1 & 0.5 & 2.6 \\
\hline 3714 & $8 / 31 / 10$ & 19.3 & 4.1 & 232.0 & 221.0 & 108.0 & 49.0 & 117.0 & 7.4 & 27.4 & 12.9 & 14.5 & 0.5 & 7.7 \\
\hline 3734 & $8 / 19 / 10$ & 18.1 & 4.8 & 361.0 & 136.0 & 116.0 & 76.4 & 98.6 & 7.5 & 31.7 & 18.4 & 13.3 & 0.6 & 3.0 \\
\hline 3780 & $8 / 9 / 11$ & 40.1 & 7.5 & 344.0 & 143.0 & 43.0 & 36.4 & 63.0 & 2.7 & 30.0 & 9.0 & 21.0 & 0.3 & 2.4 \\
\hline 3814 & $8 / 23 / 11$ & 21.2 & 2.8 & 228.0 & 199.0 & 113.1 & 51.6 & 133.6 & 11.4 & 27.2 & 13.9 & 13.4 & 0.5 & 5.4 \\
\hline 3830 & $9 / 8 / 10$ & 36.4 & 13.9 & 376.0 & 170.0 & 189.0 & 67.2 & 103.0 & 14.3 & 37.3 & 15.4 & 21.8 & 0.4 & 2.3 \\
\hline 3884 & $9 / 7 / 10$ & 38.7 & 6.6 & 179.0 & 91.4 & 197.0 & 52.0 & 123.0 & 12.8 & 23.7 & 11.6 & 12.0 & 0.5 & 2.0 \\
\hline 3920 & $8 / 18 / 10$ & 28.4 & 4.9 & 244.0 & 81.3 & 50.7 & 52.0 & 26.9 & 4.6 & 29.9 & 9.9 & 20.0 & 0.3 & 1.9 \\
\hline 3922 & $8 / 18 / 10$ & 25.7 & 4.8 & 353.0 & 66.9 & 111.0 & 52.9 & 34.6 & 6.3 & 37.3 & 22.0 & 15.3 & 0.6 & 2.6 \\
\hline 4272 & 8/8/11 & 30.1 & 5.7 & 458.0 & 313.0 & 165.1 & 111.6 & 54.1 & 2.3 & 45.1 & 19.7 & 25.3 & 0.4 & 3.1 \\
\hline 4316 & $8 / 17 / 10$ & 13.8 & 2.5 & 290.0 & 162.0 & 149.0 & 72.0 & 123.1 & 4.5 & 24.3 & 13.2 & 11.2 & 0.5 & 3.8 \\
\hline 4322 & $8 / 17 / 10$ & 22.7 & 4.4 & 542.0 & 286.0 & 96.3 & 87.4 & 71.7 & 3.5 & 55.1 & 23.5 & 31.7 & 0.4 & 2.5 \\
\hline
\end{tabular}


Table B1: Continued

\begin{tabular}{|c|c|c|c|c|c|c|c|c|c|c|c|c|c|c|}
\hline Midas & $\begin{array}{l}\text { Sample } \\
\text { Date }\end{array}$ & \%LOI & $\begin{array}{c}\text { BD- } \\
\text { Al, } \\
\mu \mathrm{mol} / \mathrm{g}\end{array}$ & $\begin{array}{c}\mathrm{NaOH}- \\
\mathrm{Al}, \\
\mu \mathrm{mol} / \mathrm{g}\end{array}$ & $\begin{array}{c}\text { HCl- } \\
\text { Al, } \\
\mu \mathrm{mol} / \mathrm{g}\end{array}$ & $\begin{array}{c}\text { BD- } \\
\text { Fe, } \\
\mu \mathrm{mol} / \mathrm{g}\end{array}$ & $\begin{array}{c}\text { NaOH- } \\
\text { Fe, } \\
\mu \mathrm{mol} / \mathrm{g}\end{array}$ & $\begin{array}{c}\text { HCl- } \\
\text { Fe, } \\
\mu \mathrm{mol} / \mathrm{g}\end{array}$ & $\begin{array}{c}\text { BD- } \\
\text { P, } \\
\mu \mathrm{mol} / \mathrm{g}\end{array}$ & $\begin{array}{c}\text { NaOH- } \\
\text { P, } \\
\mu \mathrm{mol} / \mathrm{g}\end{array}$ & $\begin{array}{c}\text { NaOH- } \\
\text { rP, } \\
\mu \mathrm{mol} / \mathrm{g}\end{array}$ & $\begin{array}{c}\text { NaOH- } \\
\text { nrP, } \\
\mu \mathrm{mol} / \mathrm{g}\end{array}$ & $\begin{array}{c}\text { NaOH- } \\
\text { rP:P }\end{array}$ & $\begin{array}{c}\text { HCl- } \\
\text { P, } \\
\mu \mathrm{mol} / \mathrm{g} \\
\end{array}$ \\
\hline 4328 & $8 / 17 / 10$ & 18.8 & 6.6 & 528.0 & 215.0 & 422.0 & 125.0 & 94.0 & 2.5 & 46.8 & 24.8 & 22.0 & 0.5 & 1.9 \\
\hline 4330 & $8 / 17 / 10$ & 22.9 & 2.4 & 399.0 & 199.0 & 82.4 & 38.7 & 38.4 & 2.9 & 34.8 & 10.9 & 23.8 & 0.3 & 2.0 \\
\hline 4336 & $8 / 17 / 10$ & 10.4 & 1.6 & 265.0 & 86.4 & 95.3 & 67.6 & 60.0 & 3.0 & 22.3 & 14.0 & 8.3 & 0.6 & 2.3 \\
\hline 4388 & $8 / 15 / 11$ & 17.5 & 2.6 & 240.0 & NA & 34.0 & 43.9 & NA & 0.0 & 16.0 & 7.0 & 8.5 & 0.5 & NA \\
\hline 4452 & $9 / 20 / 12$ & 29.4 & 4.0 & 786.0 & 108.6 & 129.0 & 212.0 & 49.5 & 0.0 & 38.5 & 11.2 & 27.3 & 0.3 & 0.7 \\
\hline 4492 & $8 / 25 / 10$ & 26.6 & 26.8 & 319.0 & 71.5 & 66.6 & 42.5 & 19.0 & 1.8 & 20.3 & 7.5 & 12.8 & 0.4 & 1.2 \\
\hline 4606 & $9 / 19 / 12$ & 24.4 & 6.2 & 531.0 & 91.0 & 166.0 & 59.9 & 68.2 & 0.0 & 30.5 & 8.9 & 21.7 & 0.3 & 0.8 \\
\hline 4608 & $9 / 19 / 12$ & 23.7 & 4.1 & 451.0 & 322.0 & 843.8 & 137.5 & 862.1 & 0.0 & 34.4 & 13.5 & 20.9 & 0.4 & 2.7 \\
\hline 4610 & $9 / 20 / 12$ & 34.0 & 7.6 & 805.0 & 96.0 & 78.0 & 88.0 & 44.0 & 0.0 & 36.7 & 15.0 & 21.7 & 0.4 & 0.7 \\
\hline 4612 & $9 / 20 / 12$ & 35.3 & 7.2 & 824.0 & 86.5 & 63.0 & 74.9 & 41.0 & 0.0 & 38.3 & 13.6 & 24.7 & 0.4 & 1.1 \\
\hline 4614 & $9 / 17 / 12$ & 42.6 & 5.5 & 248.0 & 45.0 & 49.4 & 16.8 & 24.6 & 2.9 & 28.0 & 6.9 & 21.2 & 0.3 & 1.4 \\
\hline 4618 & $9 / 20 / 12$ & 46.4 & 4.1 & 178.0 & 37.0 & 37.0 & 14.0 & 15.0 & 3.4 & 20.1 & 4.4 & 15.6 & 0.2 & 0.4 \\
\hline 4620 & $9 / 17 / 12$ & 50.4 & 5.7 & 239.0 & 36.6 & 53.5 & 15.7 & 14.8 & 2.8 & 22.3 & 5.6 & 16.6 & 0.3 & 0.7 \\
\hline 4622 & $9 / 19 / 12$ & 22.3 & 6.9 & 299.0 & 145.0 & 1064.2 & 76.7 & 541.8 & 0.4 & 37.3 & 14.7 & 22.6 & 0.4 & 0.7 \\
\hline 4624 & $9 / 17 / 12$ & 22.7 & 3.1 & 375.0 & 154.0 & 57.0 & 74.0 & 49.0 & 0.0 & 27.5 & 8.9 & 18.6 & 0.3 & 1.7 \\
\hline 4628 & $9 / 17 / 12$ & 27.6 & 5.5 & 473.0 & 122.0 & 57.0 & 40.0 & 50.8 & 0.0 & 30.5 & 10.6 & 19.9 & 0.4 & 1.5 \\
\hline 4630 & $9 / 17 / 12$ & 25.1 & 5.2 & 588.0 & 199.0 & 121.7 & 132.2 & 65.1 & 0.0 & 31.4 & 10.8 & 20.6 & 0.3 & 1.1 \\
\hline 4766 & $8 / 25 / 10$ & 23.9 & 5.8 & 434.0 & 182.0 & 174.0 & 244.0 & 54.0 & 3.2 & 51.6 & 20.0 & 31.7 & 0.4 & 2.2 \\
\hline 4782 & $9 / 8 / 11$ & 32.8 & 3.2 & 409.0 & 125.0 & 45.7 & 36.2 & 23.2 & 0.0 & 32.7 & 8.7 & 24.1 & 0.3 & 1.5 \\
\hline 4788 & $8 / 25 / 10$ & 20.8 & 2.1 & 170.0 & 48.8 & 29.2 & 17.5 & 11.3 & 0.8 & 14.2 & 4.7 & 9.5 & 0.3 & 0.8 \\
\hline 4800 & $9 / 1 / 10$ & 23.2 & 25.2 & 572.0 & 238.0 & 214.0 & 103.5 & 135.0 & 7.6 & 39.3 & 17.6 & 21.6 & 0.5 & 4.0 \\
\hline 4802 & $8 / 10 / 11$ & 27.3 & 2.7 & 223.0 & 84.0 & 28.7 & 37.5 & 41.2 & 0.0 & 23.5 & 6.2 & 17.3 & 0.3 & 0.7 \\
\hline 4806 & $8 / 10 / 11$ & 18.1 & 2.1 & 272.0 & 207.0 & 72.8 & 59.4 & 102.3 & 2.4 & 35.2 & 17.8 & 17.4 & 0.5 & 2.1 \\
\hline 4822 & $8 / 11 / 11$ & 15.2 & 1.4 & 192.0 & 209.0 & 157.7 & 57.3 & 218.6 & 16.3 & 25.3 & 18.9 & 6.3 & 0.8 & 4.4 \\
\hline 4852 & $8 / 11 / 11$ & 23.7 & 4.2 & 94.0 & 108.0 & 183.9 & 45.0 & 305.5 & 11.3 & 21.2 & 13.7 & 7.6 & 0.6 & 1.9 \\
\hline
\end{tabular}


Table B1: Continued

\begin{tabular}{|c|c|c|c|c|c|c|c|c|c|c|c|c|c|c|}
\hline Midas & $\begin{array}{c}\text { Sample } \\
\text { Date }\end{array}$ & $\%$ LOI & $\begin{array}{c}\text { BD- } \\
\text { Al, } \\
\mu \mathrm{mol} / \mathrm{g}\end{array}$ & $\begin{array}{c}\text { NaOH- } \\
\mathrm{Al}, \\
\mu \mathrm{mol} / \mathrm{g}\end{array}$ & $\begin{array}{c}\text { HCl- } \\
\text { Al, } \\
\mu \mathrm{mol} / \mathrm{g} \\
\end{array}$ & $\begin{array}{c}\text { BD- } \\
\text { Fe, } \\
\mu \mathrm{mol} / \mathrm{g}\end{array}$ & $\begin{array}{c}\mathrm{NaOH}- \\
\mathrm{Fe}, \\
\mu \mathrm{mol} / \mathrm{g}\end{array}$ & $\begin{array}{c}\text { HCl- } \\
\text { Fe, } \\
\mu \mathrm{mol} / \mathrm{g}\end{array}$ & $\begin{array}{c}\text { BD- } \\
\text { P, } \\
\mu \mathrm{mol} / \mathrm{g}\end{array}$ & $\begin{array}{c}\text { NaOH- } \\
\text { P, } \\
\mu \mathrm{mol} / \mathrm{g}\end{array}$ & $\begin{array}{c}\text { NaOH- } \\
\text { rP, } \\
\mu \mathrm{mol} / \mathrm{g}\end{array}$ & $\begin{array}{c}\text { NaOH- } \\
\text { nrP, } \\
\mu \mathrm{mol} / \mathrm{g}\end{array}$ & $\begin{array}{c}\text { NaOH- } \\
\text { rP:P }\end{array}$ & $\begin{array}{c}\text { HCl- } \\
\text { P, } \\
\mu \mathrm{mol} / \mathrm{g}\end{array}$ \\
\hline 4857 & $8 / 24 / 10$ & 27.9 & 16.2 & 290.0 & 76.0 & 74.2 & 48.3 & 38.2 & 2.9 & 18.0 & 8.0 & 10.0 & 0.4 & NA \\
\hline 4894 & $8 / 17 / 11$ & 22.8 & 1.9 & 345.0 & 146.0 & 66.9 & 106.8 & 71.6 & 1.6 & 30.8 & 11.5 & 19.3 & 0.4 & 0.9 \\
\hline 4896 & $8 / 31 / 10$ & 24.5 & 9.7 & 399.0 & 393.0 & 421.0 & 217.0 & 291.0 & 10.1 & 85.4 & 61.0 & 24.4 & 0.7 & 3.9 \\
\hline 5024 & $8 / 31 / 11$ & 29.3 & 5.7 & 241.0 & 85.0 & 111.8 & 51.9 & 58.2 & 4.4 & 22.7 & 8.7 & 14.1 & 0.4 & 1.5 \\
\hline 5172 & $8 / 11 / 11$ & 15.1 & 2.4 & 161.0 & NA & 86.9 & 40.6 & NA & 15.1 & 26.3 & 13.9 & 12.4 & 0.5 & $\mathrm{NA}$ \\
\hline 5174 & $8 / 11 / 11$ & 50.5 & 2.3 & 147.0 & 39.0 & 53.0 & 25.7 & 32.0 & 2.2 & 18.0 & 5.0 & 12.7 & 0.3 & 1.0 \\
\hline 5198 & 8/18/10 & 15.7 & 7.2 & 390.0 & 400.0 & 180.0 & 178.0 & 310.0 & 11.4 & 56.6 & 32.5 & 24.1 & 0.6 & 7.6 \\
\hline 5222 & $9 / 6 / 11$ & 13.7 & 3.5 & 407.0 & 322.0 & 104.3 & 122.8 & 255.9 & 2.8 & 35.4 & 24.6 & 10.8 & 0.7 & 3.3 \\
\hline 5236 & $8 / 19 / 10$ & 24.7 & 4.0 & 224.0 & 157.0 & 341.0 & 95.3 & 582.0 & 62.6 & 115.0 & 99.6 & 15.2 & 0.9 & 12.2 \\
\hline 5240 & $9 / 2 / 10$ & 28.5 & 18.9 & 340.0 & 115.0 & 154.0 & 108.0 & 148.0 & 10.5 & 22.7 & 12.1 & 10.6 & 0.5 & 1.7 \\
\hline 5280 & $8 / 9 / 11$ & 30.9 & 19.0 & 212.0 & 228.0 & 788.7 & 109.9 & 500.6 & 77.1 & 70.7 & 51.0 & 19.7 & 0.7 & 5.8 \\
\hline 5344 & $8 / 22 / 11$ & 15.7 & 1.6 & 194.0 & 153.0 & 101.3 & 40.9 & 73.1 & 4.7 & 29.1 & 13.9 & 15.2 & 0.5 & 5.3 \\
\hline 5348 & $8 / 22 / 11$ & 20.5 & 1.5 & 168.0 & 142.0 & 38.0 & 28.9 & 77.0 & 1.8 & 20.3 & 9.7 & 10.7 & 0.5 & 5.3 \\
\hline 5349 & $8 / 22 / 11$ & 16.3 & 1.1 & 191.0 & 155.0 & 118.7 & 40.2 & 94.0 & 7.1 & 19.6 & 10.0 & 9.5 & 0.5 & 6.2 \\
\hline 5352 & $8 / 19 / 10$ & 18.0 & 4.3 & 166.0 & 92.1 & 90.7 & 41.6 & 91.3 & 12.2 & 13.0 & 3.7 & 9.3 & 0.3 & 4.2 \\
\hline 5386 & $9 / 1 / 10$ & 25.2 & 14.1 & 490.0 & 181.0 & 143.0 & 125.0 & 96.7 & 5.1 & 41.1 & 21.2 & 19.9 & 0.5 & 2.6 \\
\hline 5400 & $8 / 31 / 10$ & 16.8 & 10.4 & 341.0 & 236.0 & 133.0 & 104.0 & 156.0 & 5.5 & 36.2 & 23.7 & 12.6 & 0.7 & 2.3 \\
\hline 5408 & $8 / 26 / 10$ & 13.0 & 20.9 & 174.0 & 129.0 & 105.0 & 51.3 & 128.0 & 16.7 & 21.6 & 15.4 & 6.3 & 0.7 & 4.0 \\
\hline 5416 & $8 / 26 / 10$ & 16.6 & 3.4 & 119.0 & 223.0 & 159.0 & 19.1 & 202.0 & 31.4 & 24.4 & 11.7 & 12.8 & 0.5 & 8.5 \\
\hline 5448 & $8 / 26 / 10$ & 16.1 & 1.7 & 112.0 & 248.0 & 142.0 & 8.8 & 394.0 & 46.7 & 38.7 & 26.9 & 11.8 & 0.7 & 11.9 \\
\hline 5458 & $9 / 2 / 10$ & 27.5 & 19.4 & 212.0 & 176.0 & 164.0 & 48.7 & 132.0 & 13.2 & 19.8 & 5.0 & 14.7 & 0.3 & 6.6 \\
\hline 5490 & $8 / 15 / 11$ & 31.0 & 5.1 & 361.0 & 104.0 & 71.7 & 56.2 & 46.4 & 1.4 & 39.5 & 14.5 & 25.0 & 0.4 & 1.8 \\
\hline 5682 & $9 / 1 / 10$ & 14.5 & 12.5 & 327.0 & 188.0 & 137.0 & 85.5 & 164.0 & 5.4 & 34.5 & 21.0 & 13.5 & 0.6 & 4.2 \\
\hline 5690 & $8 / 17 / 11$ & 15.3 & 4.0 & 411.0 & 334.0 & 158.8 & 142.4 & 207.5 & 10.9 & 44.5 & 32.0 & 12.5 & 0.7 & 7.7 \\
\hline 5710 & $8 / 17 / 11$ & 22.5 & 2.9 & 337.0 & 582.0 & 45.0 & 65.0 & 476.6 & 2.2 & 28.2 & 14.3 & 13.9 & 0.5 & 9.5 \\
\hline
\end{tabular}


Table B1: Continued

\begin{tabular}{|c|c|c|c|c|c|c|c|c|c|c|c|c|c|c|}
\hline Midas & $\begin{array}{c}\text { Sample } \\
\text { Date }\end{array}$ & $\%$ LOI & $\begin{array}{c}\text { BD- } \\
\text { Al, } \\
\mu \mathrm{mol} / \mathrm{g}\end{array}$ & $\begin{array}{c}\mathrm{NaOH}- \\
\mathrm{Al}, \\
\mu \mathrm{mol} / \mathrm{g}\end{array}$ & $\begin{array}{c}\text { HCl- } \\
\mathrm{Al}, \\
\mu \mathrm{mol} / \mathrm{g}\end{array}$ & $\begin{array}{c}\text { BD- } \\
\text { Fe, } \\
\mu \mathrm{mol} / \mathrm{g}\end{array}$ & $\begin{array}{c}\text { NaOH- } \\
\text { Fe, } \\
\mu \mathrm{mol} / \mathrm{g}\end{array}$ & $\begin{array}{c}\text { HCl- } \\
\text { Fe, } \\
\mu \mathrm{mol} / \mathrm{g}\end{array}$ & $\begin{array}{c}\text { BD- } \\
\text { P, } \\
\mu \mathrm{mol} / \mathrm{g}\end{array}$ & $\begin{array}{c}\text { NaOH- } \\
\text { P, } \\
\mu \mathrm{mol} / \mathrm{g}\end{array}$ & $\begin{array}{c}\text { NaOH- } \\
\text { rP, } \\
\mu \mathrm{mol} / \mathrm{g}\end{array}$ & $\begin{array}{c}\text { NaOH- } \\
\text { nrP, } \\
\mu \mathrm{mol} / \mathrm{g}\end{array}$ & $\begin{array}{c}\text { NaOH- } \\
\text { rP:P }\end{array}$ & $\begin{array}{c}\text { HCl- } \\
\text { P, } \\
\mu \mathrm{mol} / \mathrm{g} \\
\end{array}$ \\
\hline 5780 & $8 / 30 / 11$ & 20.8 & 4.7 & 519.0 & 172.0 & 158.0 & 163.4 & 92.0 & 1.6 & 63.0 & 35.0 & 27.8 & 0.6 & 4.9 \\
\hline 5814 & $8 / 18 / 11$ & 28.1 & 7.0 & 328.0 & 234.0 & 325.4 & 91.7 & 149.9 & 15.2 & 55.7 & 33.8 & 21.9 & 0.6 & 2.2 \\
\hline 9685 & $8 / 16 / 11$ & 12.0 & 1.9 & 269.0 & NA & 45.6 & 38.9 & NA & 0.1 & 30.1 & 14.1 & 16.0 & 0.5 & NA \\
\hline 9931 & $8 / 31 / 10$ & 26.4 & 7.0 & 190.0 & 136.0 & 180.0 & 70.7 & 231.0 & 45.0 & 56.3 & 43.1 & 13.2 & 0.8 & 6.7 \\
\hline \multicolumn{15}{|l|}{ LEA } \\
\hline 5780 & $7 / 11 / 13$ & 14.7 & 1.8 & 267.8 & 119.5 & 90.5 & 58.3 & 56.5 & 1.2 & 34.6 & NA & NA & NA & 4.7 \\
\hline 3418 & $6 / 18 / 13$ & 24.6 & 4.4 & 406.4 & 126.8 & 96.7 & 48.6 & 39.2 & 1.4 & 43.1 & NA & NA & NA & 4.1 \\
\hline 5780 & $7 / 11 / 13$ & 18.4 & 7.8 & 409.0 & 119.3 & 286.5 & 112.1 & 64.8 & 3.2 & 46.1 & NA & NA & NA & 5.6 \\
\hline 3130 & $7 / 18 / 13$ & 28.2 & 6.0 & 364.7 & 88.1 & 75.5 & 37.3 & 29.1 & 3.0 & 39.2 & NA & NA & NA & 3.6 \\
\hline 3382 & $7 / 9 / 13$ & 30.8 & 2.7 & 179.3 & 104.2 & 37.5 & 18.5 & 31.2 & 2.5 & 32.9 & NA & NA & NA & 1.0 \\
\hline 3424 & $7 / 3 / 13$ & 31.8 & 4.1 & 267.5 & 131.6 & 29.1 & 22.0 & 43.1 & 2.2 & 33.6 & NA & NA & NA & 4.4 \\
\hline 3199 & $7 / 12 / 13$ & 28.8 & 4.8 & 327.2 & 105.1 & 144.9 & 104.0 & 42.0 & 3.1 & 41.9 & NA & NA & NA & 0.7 \\
\hline 3134 & $6 / 27 / 13$ & 31.8 & 4.7 & 274.6 & 76.4 & 67.8 & 28.5 & 43.8 & 2.6 & 35.5 & NA & NA & NA & 5.0 \\
\hline 3416 & $6 / 18 / 13$ & 30.0 & 9.0 & 578.2 & 166.3 & 110.1 & 77.9 & 64.1 & 3.6 & 58.4 & NA & NA & NA & 3.4 \\
\hline 9685 & $7 / 11 / 13$ & 11.1 & 0.6 & 234.1 & 147.1 & 48.8 & 31.3 & 70.6 & 1.8 & 24.3 & NA & NA & NA & 7.1 \\
\hline 3420 & $7 / 17 / 13$ & 31.4 & 5.7 & 560.3 & 175.9 & 108.5 & 64.8 & 67.0 & 5.8 & 66.9 & NA & NA & NA & 3.7 \\
\hline 3454 & $7 / 1 / 13$ & 27.6 & 1.1 & 386.5 & 156.7 & 88.6 & 50.8 & 35.9 & 2.1 & 47.7 & NA & NA & NA & 1.7 \\
\hline 5582 & $8 / 26 / 13$ & 35.6 & 3.4 & 400.2 & 121.6 & 48.3 & 26.4 & 27.4 & 3.9 & 48.8 & NA & NA & NA & 1.6 \\
\hline 3134 & $6 / 27 / 13$ & 30.2 & 3.5 & 351.6 & 223.6 & 190.7 & 70.4 & 100.5 & 3.3 & 50.6 & NA & NA & NA & 2.9 \\
\hline 5780 & $7 / 11 / 13$ & 23.0 & 3.0 & 364.2 & 124.5 & 154.7 & 73.4 & 62.0 & 4.8 & 44.6 & NA & NA & NA & 3.0 \\
\hline 5780 & $7 / 11 / 13$ & 19.5 & 2.4 & 318.8 & 128.0 & 109.5 & 55.0 & 51.9 & 2.6 & 33.3 & NA & NA & NA & 3.3 \\
\hline 3132 & $7 / 18 / 13$ & 32.1 & 2.1 & 253.9 & 104.4 & 80.6 & 27.3 & 24.7 & 2.5 & 29.2 & NA & NA & NA & 1.3 \\
\hline 3126 & $7 / 18 / 13$ & 25.8 & 3.2 & 311.9 & 86.5 & 49.3 & 21.3 & 16.3 & 5.6 & 43.0 & NA & NA & NA & 0.2 \\
\hline 3234 & $7 / 1 / 13$ & 39.8 & 5.7 & 456.0 & 128.8 & 97.3 & 47.6 & 31.1 & 5.2 & 56.6 & NA & NA & NA & 0.4 \\
\hline 3374 & $6 / 24 / 13$ & 25.9 & 1.8 & 211.6 & 118.1 & 76.3 & 19.0 & 28.9 & 5.2 & 31.0 & NA & NA & NA & 2.3 \\
\hline
\end{tabular}


Table B1: Continued

\begin{tabular}{|c|c|c|c|c|c|c|c|c|c|c|c|c|c|c|}
\hline Midas & $\begin{array}{c}\text { Sample } \\
\text { Date }\end{array}$ & $\%$ LOI & $\begin{array}{c}\text { BD- } \\
\text { Al, } \\
\mu \mathrm{mol} / \mathrm{g}\end{array}$ & $\begin{array}{c}\mathrm{NaOH}- \\
\mathrm{Al}, \\
\mu \mathrm{mol} / \mathrm{g}\end{array}$ & $\begin{array}{c}\text { HCl- } \\
\mathrm{Al}, \\
\mu \mathrm{mol} / \mathrm{g}\end{array}$ & $\begin{array}{c}\text { BD- } \\
\text { Fe, } \\
\mu \mathrm{mol} / \mathrm{g}\end{array}$ & $\begin{array}{c}\mathrm{NaOH}- \\
\mathrm{Fe}, \\
\mu \mathrm{mol} / \mathrm{g}\end{array}$ & $\begin{array}{c}\text { HCl- } \\
\text { Fe, } \\
\mu \mathrm{mol} / \mathrm{g}\end{array}$ & $\begin{array}{c}\text { BD- } \\
\text { P, } \\
\mu \mathrm{mol} / \mathrm{g}\end{array}$ & $\begin{array}{c}\mathrm{NaOH}- \\
\mathrm{P}, \\
\mu \mathrm{mol} / \mathrm{g}\end{array}$ & $\begin{array}{l}\mathrm{NaOH}- \\
\mathrm{rP}, \\
\mu \mathrm{mol} / \mathrm{g}\end{array}$ & $\begin{array}{c}\text { NaOH- } \\
\text { nrP, } \\
\mu \mathrm{mol} / \mathrm{g}\end{array}$ & $\begin{array}{l}\text { NaOH- } \\
\text { rP:P }\end{array}$ & $\begin{array}{c}\text { HCl- } \\
\text { P, } \\
\mu \mathrm{mol} / \mathrm{g}\end{array}$ \\
\hline 3134 & $6 / 27 / 13$ & 27.2 & 1.8 & 311.9 & 108.0 & 72.2 & 31.7 & 37.1 & 2.0 & 32.7 & NA & NA & NA & 1.9 \\
\hline 3452 & $7 / 31 / 13$ & 19.8 & 3.1 & 404.7 & 156.3 & 151.1 & 61.8 & 71.4 & 2.6 & 39.5 & NA & NA & NA & 5.2 \\
\hline 3454 & $7 / 1 / 13$ & 28.3 & 1.8 & 435.0 & 151.3 & 73.0 & 50.1 & 39.6 & 2.6 & 55.0 & NA & NA & NA & 2.2 \\
\hline 3448 & $8 / 1 / 13$ & 32.2 & 2.6 & 407.0 & 100.4 & 36.9 & 28.9 & 22.3 & 2.6 & 37.9 & NA & NA & NA & 0.9 \\
\hline 3232 & $7 / 16 / 13$ & 31.5 & 3.1 & 490.4 & 172.9 & 72.0 & 54.0 & 51.2 & 3.5 & 48.3 & NA & NA & NA & 2.4 \\
\hline 3456 & $9 / 10 / 13$ & 40.6 & 8.1 & 712.4 & 102.1 & 192.6 & 114.7 & 51.0 & 2.5 & 55.8 & NA & NA & NA & 0.5 \\
\hline 5780 & NA & 22.3 & 4.7 & 372.2 & 182.1 & 159.0 & 103.3 & 79.7 & 3.9 & 54.4 & NA & NA & NA & 4.2 \\
\hline
\end{tabular}


Table B2: Sediment Chemistry from the Bottom $(8-10 \mathrm{~cm})$. Data reports the 2015, 2016, and DEP studies. The DEP did not provide the calcium fraction analysis and the LEA did not provide fractionation results for the deeper sediment.

\begin{tabular}{|c|c|c|c|c|c|c|c|c|c|c|c|c|c|c|}
\hline Midas & $\begin{array}{c}\text { Sample } \\
\text { Date }\end{array}$ & $\%$ LOI & $\begin{array}{c}\text { BD- } \\
\text { Al, } \\
\mu \mathrm{mol} / \mathrm{g} \\
\end{array}$ & $\begin{array}{c}\text { NaOH- } \\
\text { Al, } \\
\mu \mathrm{mol} / \mathrm{g}\end{array}$ & $\begin{array}{c}\text { HCl- } \\
\text { Al, } \\
\mu \mathrm{mol} / \mathrm{g}\end{array}$ & $\begin{array}{c}\begin{array}{c}\text { BD- } \\
\text { Fe, } \\
\mu \mathrm{mol} / \mathrm{g}\end{array} \\
\end{array}$ & $\begin{array}{c}\mathrm{NaOH}- \\
\mathrm{Fe}, \\
\mu \mathrm{mol} / \mathrm{g}\end{array}$ & $\begin{array}{c}\text { HCl- } \\
\text { Fe, } \\
\mu \mathrm{mol} / \mathrm{g}\end{array}$ & $\begin{array}{c}\text { BD- } \\
\text { P, } \\
\mu \mathrm{mol} / \mathrm{g}\end{array}$ & $\begin{array}{c}\text { NaOH- } \\
\text { P, } \\
\mu \mathrm{mol} / \mathrm{g}\end{array}$ & $\begin{array}{c}\mathrm{NaOH}- \\
\mathrm{rP}, \\
\mu \mathrm{mol} / \mathrm{g} \\
\end{array}$ & $\begin{array}{c}\text { NaOH- } \\
\text { nrP, } \\
\mu \mathrm{mol} / \mathrm{g}\end{array}$ & $\begin{array}{c}\text { NaOH- } \\
\text { rP:P }\end{array}$ & $\begin{array}{c}\text { HCl- } \\
\text { P, } \\
\mu \mathrm{mol} / \mathrm{g}\end{array}$ \\
\hline \multicolumn{15}{|l|}{2015} \\
\hline 3748 & $6 / 26 / 15$ & 8.3 & 2.5 & 79.7 & 298.9 & 50.2 & 3.9 & 247.0 & 4.0 & 16.9 & NA & NA & NA & 9.1 \\
\hline 5448 & $6 / 24 / 15$ & 11.3 & 0.9 & 72.8 & 271.2 & 56.8 & 25.6 & 267.5 & 7.1 & 15.7 & NA & NA & NA & 8.2 \\
\hline 5190 & $7 / 8 / 15$ & 24.9 & 6.1 & 219.4 & 199.4 & 31.6 & 31.4 & 65.0 & 2.3 & 33.6 & NA & NA & NA & 1.5 \\
\hline 5400 & $7 / 13 / 15$ & 6.1 & 4.2 & 345.1 & 318.2 & 77.6 & 118.6 & 133.1 & 3.2 & 34.2 & NA & NA & NA & 3.1 \\
\hline 5349 & $6 / 25 / 15$ & 14.7 & 0.7 & 156.2 & 165.1 & 15.5 & 23.1 & 97.3 & 1.0 & 9.5 & NA & NA & NA & 6.0 \\
\hline 78 & $7 / 9 / 15$ & 25.2 & 2.9 & 234.8 & 276.3 & 164.2 & 61.1 & 189.1 & 2.4 & 42.5 & NA & NA & NA & 3.2 \\
\hline 5274 & $7 / 6 / 15$ & 16.5 & 4.7 & 191.0 & 211.3 & 47.4 & 37.1 & 119.1 & 3.0 & 32.8 & NA & NA & NA & 5.2 \\
\hline 4538 & $7 / 10 / 15$ & 32.1 & 3.0 & 645.1 & 155.6 & 34.9 & 32.0 & 37.1 & 0.8 & 50.3 & $\mathrm{NA}$ & NA & NA & 2.8 \\
\hline 5272 & $7 / 6 / 15$ & 27.6 & 9.2 & 272.9 & 201.3 & 65.1 & 43.6 & 79.1 & 4.3 & 43.3 & NA & NA & NA & 2.4 \\
\hline 5348 & $7 / 2 / 15$ & 17.6 & 1.4 & 164.8 & 225.2 & 29.5 & 22.8 & 114.6 & 2.0 & 24.1 & NA & NA & NA & 7.7 \\
\hline 177 & $6 / 30 / 15$ & 4.7 & 2.5 & 46.3 & 216.5 & 13.2 & 1.1 & 260.0 & 0.4 & 2.0 & NA & NA & NA & 8.1 \\
\hline 5280 & $7 / 2 / 15$ & 23.8 & 5.4 & 278.9 & 267.6 & 124.3 & 73.2 & 171.1 & 7.1 & 41.7 & NA & NA & NA & 3.3 \\
\hline 3838 & $6 / 29 / 15$ & 33.0 & 3.7 & 435.3 & 237.9 & 133.2 & 88.1 & 119.1 & 5.4 & 64.9 & NA & NA & NA & 1.7 \\
\hline 5344 & $6 / 25 / 15$ & 15.1 & 1.0 & 178.2 & 171.8 & 46.0 & 12.3 & 97.6 & 2.2 & 28.3 & NA & NA & NA & 4.9 \\
\hline 224 & $7 / 8 / 15$ & 20.3 & 1.7 & 282.5 & 225.3 & 106.1 & 26.5 & 213.2 & 3.2 & 44.4 & NA & NA & NA & 3.6 \\
\hline 3446 & $7 / 7 / 15$ & 26.0 & 1.3 & 197.4 & 172.2 & 20.8 & 13.4 & 59.8 & 1.5 & 31.5 & NA & NA & NA & 4.3 \\
\hline 3796 & $6 / 26 / 15$ & 11.0 & 3.0 & 145.7 & 243.5 & 55.0 & 4.6 & 215.7 & 3.2 & 10.2 & NA & NA & NA & 3.8 \\
\hline 5352 & $7 / 2 / 15$ & 16.0 & 2.5 & 142.7 & 222.8 & 51.8 & 28.4 & 142.4 & 3.7 & 17.2 & NA & NA & NA & 6.1 \\
\hline 3916 & $6 / 29 / 15$ & 40.3 & 2.1 & 157.9 & 49.9 & 34.1 & 8.3 & 30.6 & 2.1 & 24.8 & NA & NA & NA & NA \\
\hline 3750 & $7 / 9 / 15$ & 16.6 & 1.8 & 162.9 & 220.3 & 47.2 & 14.7 & 159.9 & 2.4 & 24.8 & NA & NA & NA & 9.2 \\
\hline 3444 & $7 / 7 / 15$ & 21.3 & 2.1 & 372.6 & 147.8 & 98.3 & 41.2 & 115.8 & 2.5 & 47.7 & NA & NA & NA & 2.5 \\
\hline
\end{tabular}


Table B2: Continued

\begin{tabular}{|c|c|c|c|c|c|c|c|c|c|c|c|c|c|c|}
\hline Midas & $\begin{array}{c}\text { Sample } \\
\text { Date }\end{array}$ & $\%$ LOI & $\begin{array}{c}\text { BD- } \\
\text { Al, } \\
\mu \mathrm{mol} / \mathrm{g}\end{array}$ & $\begin{array}{c}\text { NaOH- } \\
\text { Al, } \\
\mu \mathrm{mol} / \mathrm{g}\end{array}$ & $\begin{array}{c}\text { HCl- } \\
\mathrm{Al}, \\
\mu \mathrm{mol} / \mathrm{g} \\
\end{array}$ & $\begin{array}{c}\text { BD- } \\
\text { Fe, } \\
\mu \mathrm{mol} / \mathrm{g}\end{array}$ & $\begin{array}{c}\text { NaOH- } \\
\text { Fe, } \\
\mu \mathrm{mol} / \mathrm{g}\end{array}$ & $\begin{array}{c}\text { HCl- } \\
\text { Fe, } \\
\mu \mathrm{mol} / \mathrm{g}\end{array}$ & $\begin{array}{c}\text { BD- } \\
\text { P, } \\
\mu \mathrm{mol} / \mathrm{g}\end{array}$ & $\begin{array}{c}\text { NaOH- } \\
\text { P, } \\
\mu \mathrm{mol} / \mathrm{g}\end{array}$ & $\begin{array}{c}\text { NaOH- } \\
\text { rP, } \\
\mu \mathrm{mol} / \mathrm{g}\end{array}$ & $\begin{array}{c}\text { NaOH- } \\
\text { nrP, } \\
\mu \mathrm{mol} / \mathrm{g}\end{array}$ & $\begin{array}{c}\mathrm{NaOH}- \\
\text { rP:P }\end{array}$ & $\begin{array}{c}\text { HCl- } \\
\text { P, } \\
\mu \mathrm{mol} / \mathrm{g}\end{array}$ \\
\hline 4434 & $6 / 30 / 15$ & 51.5 & 1.6 & 508.3 & 323.4 & 162.9 & 223.8 & 89.4 & 1.0 & 60.5 & NA & NA & NA & 0.8 \\
\hline 5172 & $7 / 1 / 15$ & 13.5 & 2.3 & 122.0 & 195.9 & 56.6 & 30.3 & 134.4 & 3.7 & 25.4 & NA & NA & NA & 5.0 \\
\hline 5408 & $6 / 24 / 15$ & 11.5 & 3.7 & 89.0 & 275.5 & 77.0 & 14.2 & 264.0 & 8.3 & 32.6 & NA & NA & NA & 6.6 \\
\hline \multicolumn{15}{|l|}{2016} \\
\hline 4444 & $6 / 24 / 16$ & 10.9 & 2.3 & 347.7 & 160.4 & 44.9 & 69.2 & 90.0 & 2.9 & 20.5 & NA & NA & NA & 7.4 \\
\hline 5666 & $6 / 28 / 16$ & 29.4 & 2.0 & 261.2 & 166.8 & 39.8 & 29.8 & 66.3 & 2.6 & 42.0 & NA & NA & NA & 2.4 \\
\hline 5814 & $6 / 23 / 16$ & 21.7 & 2.3 & 405.0 & 226.4 & 69.3 & 79.9 & 94.5 & 3.6 & 56.5 & NA & NA & NA & 2.5 \\
\hline 5182 & $6 / 23 / 16$ & 14.3 & 3.4 & 411.8 & 269.8 & 70.8 & 86.4 & 141.9 & 2.0 & 35.0 & NA & NA & NA & 3.2 \\
\hline 4406 & $6 / 27 / 16$ & 15.0 & 1.3 & 330.5 & 131.9 & 103.4 & 72.1 & 88.9 & 12.7 & 18.4 & NA & NA & NA & 4.3 \\
\hline 5330 & $6 / 29 / 16$ & 22.9 & 2.0 & 407.7 & 156.4 & 34.3 & 81.3 & 56.8 & 1.3 & 36.5 & NA & NA & NA & 1.6 \\
\hline 5664 & $6 / 30 / 16$ & 19.5 & 1.4 & 319.4 & 279.0 & 62.5 & 55.6 & 133.5 & 2.5 & 34.0 & NA & NA & NA & 5.5 \\
\hline 3760 & $6 / 22 / 16$ & 26.5 & 1.3 & 249.0 & 232.7 & 70.0 & 45.0 & 98.9 & 3.3 & 38.2 & NA & NA & NA & 3.2 \\
\hline 3762 & $6 / 22 / 16$ & 23.5 & 1.8 & 306.0 & 165.8 & 35.9 & 35.9 & 62.8 & 2.8 & 42.2 & NA & NA & NA & 3.7 \\
\hline 5812 & $6 / 29 / 16$ & 20.6 & 4.4 & 440.0 & 303.8 & 134.8 & 117.8 & 168.7 & 6.0 & 53.2 & NA & NA & NA & 3.4 \\
\hline 4448 & $6 / 24 / 16$ & 6.3 & 3.0 & 323.4 & 113.5 & 26.7 & 65.9 & 72.1 & 0.5 & 8.8 & NA & NA & NA & 6.5 \\
\hline 5186 & $6 / 29 / 16$ & 21.3 & 1.3 & 246.1 & 209.8 & 33.0 & 30.6 & 86.4 & 1.3 & 37.0 & NA & NA & NA & 3.8 \\
\hline 3826 & $6 / 30 / 16$ & 50.7 & 2.7 & 170.3 & 62.9 & 35.3 & 17.1 & 41.4 & 0.5 & 16.8 & NA & NA & NA & 0.6 \\
\hline 3824 & $6 / 30 / 16$ & 11.8 & 1.2 & 231.1 & 200.8 & 55.9 & 50.6 & 113.2 & 2.7 & 21.9 & NA & NA & NA & 10.9 \\
\hline 4446 & $6 / 27 / 16$ & 61.5 & 2.5 & 199.0 & 37.7 & 77.9 & 25.7 & 28.2 & 3.3 & 20.2 & NA & NA & NA & 0.4 \\
\hline 3688 & $6 / 23 / 16$ & 26.2 & 1.6 & 154.5 & 131.4 & 27.4 & 13.0 & 36.3 & 2.6 & 30.6 & NA & NA & NA & 2.1 \\
\hline 4346 & $6 / 24 / 16$ & 10.9 & 3.3 & 364.8 & 104.6 & 42.1 & 67.1 & 65.4 & 1.2 & 22.3 & NA & NA & NA & 5.4 \\
\hline 5184 & $6 / 28 / 16$ & 46.0 & 2.1 & 178.7 & 59.9 & 11.0 & 8.6 & 23.2 & 3.2 & 28.2 & NA & NA & NA & 1.7 \\
\hline \multicolumn{15}{|l|}{ DEP } \\
\hline 70 & $8 / 9 / 11$ & 24.7 & 1.6 & 328.0 & 198.0 & 65.6 & 98.2 & 70.9 & 2.8 & 40.1 & 21.6 & 18.5 & 0.5 & 2.3 \\
\hline 80 & $8 / 24 / 11$ & 14.8 & 1.2 & 346.0 & 173.0 & 51.0 & 95.3 & 83.0 & 1.8 & 41.8 & 23.6 & 18.2 & 0.6 & 5.8 \\
\hline
\end{tabular}


Table B2: Continued

\begin{tabular}{|c|c|c|c|c|c|c|c|c|c|c|c|c|c|c|}
\hline Midas & $\begin{array}{c}\text { Sample } \\
\text { Date }\end{array}$ & $\%$ LOI & $\begin{array}{c}\text { BD- } \\
\text { Al, } \\
\mu \mathrm{mol} / \mathrm{g}\end{array}$ & $\begin{array}{c}\text { NaOH- } \\
\text { Al, } \\
\mu \mathrm{mol} / \mathrm{g}\end{array}$ & $\begin{array}{c}\text { HCl- } \\
\text { Al, } \\
\mu \mathrm{mol} / \mathrm{g} \\
\end{array}$ & $\begin{array}{c}\text { BD- } \\
\text { Fe, } \\
\mu \mathrm{mol} / \mathrm{g} \\
\end{array}$ & $\begin{array}{c}\text { NaOH- } \\
\text { Fe, } \\
\mu \mathrm{mol} / \mathrm{g}\end{array}$ & $\begin{array}{c}\text { HCl- } \\
\text { Fe, } \\
\mu \mathrm{mol} / \mathrm{g}\end{array}$ & $\begin{array}{c}\begin{array}{c}\text { BD- } \\
\text { P, } \\
\mu \mathrm{mol} / \mathrm{g}\end{array} \\
\end{array}$ & $\begin{array}{c}\text { NaOH- } \\
\text { P, } \\
\mu \mathrm{mol} / \mathrm{g}\end{array}$ & $\begin{array}{c}\mathrm{NaOH}- \\
\mathbf{r P}, \\
\mu \mathrm{mol} / \mathrm{g}\end{array}$ & $\begin{array}{c}\text { NaOH- } \\
\text { nrP, } \\
\mu \mathrm{mol} / \mathrm{g}\end{array}$ & $\begin{array}{c}\mathrm{NaOH}- \\
\text { rP:P }\end{array}$ & $\begin{array}{c}\text { HCl- } \\
\mathrm{P}, \\
\mu \mathrm{mol} / \mathrm{g}\end{array}$ \\
\hline 121 & $8 / 24 / 11$ & 24.0 & 2.1 & 237.0 & 120.0 & 25.6 & 37.4 & 56.8 & 1.1 & 36.3 & 20.0 & 16.3 & 0.6 & 4.8 \\
\hline 177 & $9 / 23 / 10$ & 6.6 & 2.3 & 94.0 & 118.0 & 16.1 & 24.8 & 132.1 & 0.0 & 2.2 & 1.3 & 0.9 & 0.6 & 7.9 \\
\hline 243 & $9 / 1 / 11$ & 25.9 & 4.3 & 532.0 & 170.4 & 87.1 & 145.0 & 47.2 & 0.0 & 50.1 & 25.2 & 24.9 & 0.5 & 1.9 \\
\hline 262 & $8 / 30 / 10$ & 23.4 & 7.3 & 372.0 & 103.0 & 35.4 & 51.6 & 39.1 & 1.5 & 35.2 & 19.9 & 15.4 & 0.6 & 1.4 \\
\hline 342 & $9 / 1 / 11$ & 19.3 & 2.6 & 380.0 & 262.5 & 92.1 & 102.4 & 92.6 & 1.6 & 32.6 & 18.5 & 14.1 & 0.6 & 2.4 \\
\hline 386 & $8 / 23 / 11$ & 15.4 & 1.4 & 190.0 & 186.0 & 69.0 & 48.2 & 101.8 & 1.6 & 19.8 & 11.0 & 8.7 & 0.6 & 1.2 \\
\hline 410 & $9 / 1 / 11$ & 13.1 & 1.6 & 223.0 & 334.0 & 141.0 & 162.4 & 406.3 & 0.9 & 34.4 & 20.8 & 13.6 & 0.6 & 1.3 \\
\hline 447 & $9 / 23 / 12$ & 19.5 & 0.7 & 70.0 & 130.0 & 1.0 & 5.5 & 25.0 & 0.0 & 4.0 & 1.0 & 2.7 & 0.2 & 2.0 \\
\hline 760 & $8 / 30 / 10$ & 43.2 & 2.4 & 167.0 & 97.3 & 17.5 & 24.8 & 46.6 & 1.5 & 14.0 & 6.7 & 7.3 & 0.5 & 4.8 \\
\hline 954 & $8 / 23 / 10$ & 29.0 & 3.8 & 479.0 & 143.0 & 47.1 & 124.0 & 50.3 & 0.9 & 39.7 & 19.5 & 20.2 & 0.5 & 4.8 \\
\hline 1068 & $8 / 24 / 11$ & 4.9 & 0.9 & 90.0 & 56.4 & 8.4 & 17.2 & 22.6 & 0.5 & 10.5 & 4.0 & 6.5 & 0.4 & 5.3 \\
\hline 1070 & $8 / 24 / 11$ & 20.8 & 3.9 & 359.0 & 214.0 & 80.0 & 113.0 & 92.0 & 4.0 & 61.8 & 32.6 & 29.2 & 0.5 & 4.0 \\
\hline 1078 & $8 / 22 / 11$ & 18.4 & 1.0 & 142.0 & 170.0 & 67.0 & 75.4 & 282.4 & 0.2 & 23.6 & 16.2 & 7.4 & 0.7 & 5.3 \\
\hline 1088 & $8 / 22 / 11$ & 27.6 & 2.8 & 435.0 & 156.5 & 77.0 & 138.9 & 47.6 & 0.0 & 51.4 & 29.9 & 21.5 & 0.6 & 2.4 \\
\hline 1150 & $9 / 23 / 10$ & 18.7 & 2.1 & 205.0 & 194.0 & 113.5 & 82.5 & 97.5 & 1.6 & 36.9 & 19.5 & 17.4 & 0.5 & 2.5 \\
\hline 1210 & $8 / 25 / 10$ & 29.6 & 5.0 & 501.0 & 145.0 & 68.8 & 129.0 & 42.0 & 1.7 & 50.5 & 29.4 & 21.2 & 0.6 & 1.1 \\
\hline 2004 & $8 / 23 / 10$ & 26.6 & 2.5 & 873.0 & 183.0 & 16.1 & 99.0 & 29.4 & 0.4 & 57.3 & 27.9 & 29.4 & 0.5 & 3.5 \\
\hline 2020 & $8 / 15 / 11$ & 15.9 & 2.2 & 208.0 & 187.0 & 89.0 & 106.0 & 169.0 & 1.4 & 31.5 & 23.6 & 7.9 & 0.8 & 5.7 \\
\hline 2146 & $8 / 17 / 11$ & 24.4 & 2.6 & 386.0 & 209.0 & 41.0 & 68.0 & 39.0 & 2.1 & 57.2 & 34.7 & 22.6 & 0.6 & 2.7 \\
\hline 2156 & $8 / 24 / 11$ & 29.4 & 1.9 & 196.0 & 142.1 & 41.8 & 39.8 & 81.0 & 1.2 & 20.7 & 8.9 & 11.8 & 0.4 & 5.9 \\
\hline 2242 & $8 / 17 / 11$ & 39.9 & 1.1 & 167.0 & 116.0 & 11.0 & 22.1 & 48.8 & 1.8 & 15.5 & 6.5 & 9.0 & 0.4 & 1.6 \\
\hline 2286 & $9 / 2 / 10$ & 17.0 & 2.1 & 120.0 & 116.0 & 42.7 & 16.7 & 80.2 & 2.9 & 16.1 & 9.6 & 6.5 & 0.6 & 5.9 \\
\hline 2590 & $8 / 30 / 10$ & 20.4 & 7.3 & 446.0 & 183.0 & 35.4 & 78.7 & 74.8 & 1.7 & 49.2 & 27.0 & 22.2 & 0.6 & 4.1 \\
\hline 2608 & $8 / 30 / 10$ & 19.6 & 5.8 & 348.0 & 178.0 & 31.0 & 55.8 & 51.2 & 1.9 & 41.9 & 23.3 & 18.6 & 0.6 & 4.6 \\
\hline 2948 & $8 / 30 / 10$ & 10.2 & 9.5 & 113.0 & 114.0 & 62.9 & 48.8 & 122.0 & 2.0 & 14.1 & 9.1 & 5.0 & 0.7 & 8.9 \\
\hline
\end{tabular}


Table B2: Continued

\begin{tabular}{|c|c|c|c|c|c|c|c|c|c|c|c|c|c|c|}
\hline Midas & $\begin{array}{c}\text { Sample } \\
\text { Date }\end{array}$ & $\%$ LOI & $\begin{array}{c}\text { BD- } \\
\text { Al, } \\
\mu \mathrm{mol} / \mathrm{g}\end{array}$ & $\begin{array}{c}\text { NaOH- } \\
\text { Al, } \\
\mu \mathrm{mol} / \mathrm{g}\end{array}$ & $\begin{array}{c}\text { HCl- } \\
\text { Al, } \\
\mu \mathrm{mol} / \mathrm{g}\end{array}$ & $\begin{array}{c}\text { BD- } \\
\text { Fe, } \\
\mu \mathrm{mol} / \mathrm{g}\end{array}$ & $\begin{array}{c}\text { NaOH- } \\
\text { Fe, } \\
\mu \mathrm{mol} / \mathrm{g}\end{array}$ & $\begin{array}{c}\begin{array}{c}\mathrm{HCl}- \\
\mathrm{Fe}, \\
\mu \mathrm{mol} / \mathrm{g}\end{array} \\
\end{array}$ & $\begin{array}{c}\text { BD- } \\
\text { P, } \\
\mu \mathrm{mol} / \mathrm{g}\end{array}$ & $\begin{array}{c}\text { NaOH- } \\
\text { P, } \\
\mu \mathrm{mol} / \mathrm{g}\end{array}$ & $\begin{array}{c}\mathrm{NaOH}- \\
\mathrm{rP}, \\
\mu \mathrm{mol} / \mathrm{g}\end{array}$ & $\begin{array}{c}\text { NaOH- } \\
\text { nrP, } \\
\mu \mathrm{mol} / \mathrm{g}\end{array}$ & $\begin{array}{l}\text { NaOH- } \\
\text { rP:P }\end{array}$ & $\begin{array}{c}\text { HCl- } \\
\text { P, } \\
\mu \mathrm{mol} / \mathrm{g} \\
\end{array}$ \\
\hline 3038 & $8 / 24 / 11$ & 8.3 & 0.8 & 181.0 & 144.0 & 23.0 & 53.0 & 97.0 & 0.1 & 24.3 & 15.6 & 8.8 & 0.6 & 5.8 \\
\hline 3376 & $8 / 25 / 11$ & 34.2 & 2.3 & 177.0 & 74.0 & 22.3 & 9.4 & 13.7 & 3.0 & 33.6 & 14.0 & 19.6 & 0.4 & 1.0 \\
\hline 3388 & $9 / 7 / 10$ & 13.8 & 1.5 & 99.1 & 69.5 & 12.4 & 8.0 & 16.7 & 0.5 & 14.0 & 5.3 & 8.7 & 0.4 & 4.2 \\
\hline 3434 & $9 / 1 / 10$ & 28.6 & 6.0 & 422.0 & 164.0 & 24.5 & 48.2 & 56.3 & 2.0 & 37.2 & 23.1 & 14.1 & 0.6 & 5.0 \\
\hline 3452 & $8 / 31 / 10$ & 17.7 & 15.6 & 361.0 & 170.0 & 25.3 & 41.4 & 58.7 & 1.5 & 37.0 & 22.8 & 14.2 & 0.6 & 7.4 \\
\hline 3454 & $8 / 16 / 11$ & 28.8 & 2.3 & 353.0 & NA & 23.6 & 32.1 & NA & 0.0 & 42.2 & 21.9 & 20.4 & 0.5 & NA \\
\hline 3604 & $8 / 18 / 11$ & 17.7 & 3.9 & 290.0 & 161.0 & 27.9 & 32.2 & 62.0 & 1.5 & 34.9 & 21.9 & 13.0 & 0.6 & 5.2 \\
\hline 3626 & $9 / 1 / 10$ & 17.8 & 11.9 & 195.0 & 141.0 & 41.5 & 46.3 & 76.9 & 2.5 & 11.8 & 7.8 & 4.0 & 0.7 & 8.2 \\
\hline 3672 & $8 / 10 / 11$ & 17.2 & 2.4 & 299.0 & 286.0 & 65.0 & 91.1 & 173.5 & 0.1 & 40.7 & 30.1 & 10.6 & 0.7 & 4.2 \\
\hline 3682 & $8 / 10 / 11$ & 21.4 & 4.4 & 422.0 & 274.0 & 97.0 & 138.0 & 192.0 & 0.2 & 40.7 & 26.0 & 14.8 & 0.6 & 2.0 \\
\hline 3690 & $8 / 31 / 10$ & 21.9 & 4.5 & 140.0 & 98.2 & 25.7 & 14.3 & 32.8 & 2.8 & 23.3 & 11.1 & 12.3 & 0.5 & 3.7 \\
\hline 3696 & $8 / 31 / 11$ & 15.5 & 1.2 & 138.0 & 119.0 & 26.7 & 17.5 & 48.6 & 1.4 & 25.4 & 14.3 & 11.2 & 0.6 & 8.2 \\
\hline 3712 & $8 / 19 / 10$ & 29.5 & 4.8 & 384.0 & 129.0 & 61.3 & 42.3 & 43.9 & 3.4 & 44.0 & 22.8 & 21.2 & 0.5 & 2.6 \\
\hline 3714 & $8 / 31 / 10$ & 16.2 & 6.4 & 166.0 & 224.0 & 42.8 & 30.8 & 89.3 & 2.3 & 27.8 & 15.1 & 12.7 & 0.5 & 7.8 \\
\hline 3734 & $8 / 19 / 10$ & 13.0 & 3.1 & 441.0 & 217.0 & 47.1 & 92.6 & 110.5 & 2.4 & 32.6 & 21.4 & 11.3 & 0.7 & 5.3 \\
\hline 3780 & $8 / 9 / 11$ & 36.1 & 4.1 & 359.0 & 169.7 & 35.6 & 39.0 & 69.3 & 0.0 & 23.3 & 9.1 & 14.2 & 0.4 & 2.4 \\
\hline 3814 & $8 / 23 / 11$ & 15.9 & 0.9 & 155.0 & 200.0 & 32.5 & 31.9 & 118.0 & 1.2 & 17.1 & 9.1 & 8.1 & 0.5 & 7.3 \\
\hline 3830 & $9 / 8 / 10$ & 33.5 & 8.3 & 336.0 & 141.0 & 36.1 & 46.8 & 64.7 & 2.8 & 31.0 & 17.5 & 13.5 & 0.6 & 3.0 \\
\hline 3884 & $9 / 7 / 10$ & 37.1 & 4.0 & 229.0 & 137.0 & 83.2 & 49.8 & 99.1 & 3.2 & 29.2 & 16.3 & 13.0 & 0.6 & 2.8 \\
\hline 3920 & $8 / 18 / 10$ & 26.5 & 2.5 & 212.0 & 99.5 & 15.7 & 29.0 & 19.3 & 1.5 & 32.0 & 13.2 & 18.8 & 0.4 & 1.7 \\
\hline 3922 & $8 / 18 / 10$ & 26.4 & 2.4 & 265.0 & 143.0 & 38.7 & 42.1 & 36.1 & 2.2 & 49.5 & 31.7 & 17.8 & 0.6 & 3.0 \\
\hline 4272 & $8 / 8 / 11$ & 27.0 & 2.7 & 290.0 & 261.0 & 12.6 & 43.2 & 25.1 & 0.6 & 35.1 & 18.6 & 16.5 & 0.5 & 3.0 \\
\hline 4316 & $8 / 17 / 10$ & NA & NA & NA & NA & NA & NA & NA & NA & NA & NA & NA & NA & NA \\
\hline 4322 & $8 / 17 / 10$ & 25.1 & 2.8 & 296.0 & 261.3 & 21.5 & 62.7 & 34.4 & 0.9 & 35.9 & 17.9 & 18.0 & 0.5 & 1.3 \\
\hline 4328 & $8 / 17 / 10$ & 14.9 & 2.5 & 375.0 & 196.0 & 54.4 & 75.0 & 83.4 & 1.4 & 35.3 & 22.1 & 13.2 & 0.6 & 3.1 \\
\hline
\end{tabular}


Table B2: Continued

\begin{tabular}{|c|c|c|c|c|c|c|c|c|c|c|c|c|c|c|}
\hline Midas & $\begin{array}{c}\text { Sample } \\
\text { Date }\end{array}$ & $\%$ LOI & $\begin{array}{c}\text { BD- } \\
\text { Al, } \\
\mu \mathrm{mol} / \mathrm{g}\end{array}$ & $\begin{array}{c}\text { NaOH- } \\
\text { Al, } \\
\mu \mathrm{mol} / \mathrm{g}\end{array}$ & $\begin{array}{c}\text { HCl- } \\
\text { Al, } \\
\mu \mathrm{mol} / \mathrm{g} \\
\end{array}$ & $\begin{array}{c}\text { BD- } \\
\text { Fe, } \\
\mu \mathrm{mol} / \mathrm{g} \\
\end{array}$ & $\begin{array}{c}\text { NaOH- } \\
\text { Fe, } \\
\mu \mathrm{mol} / \mathrm{g}\end{array}$ & $\begin{array}{c}\text { HCl- } \\
\text { Fe, } \\
\mu \mathrm{mol} / \mathrm{g}\end{array}$ & $\begin{array}{c}\begin{array}{c}\text { BD- } \\
\text { P, } \\
\mu \mathrm{mol} / \mathrm{g}\end{array} \\
\end{array}$ & $\begin{array}{c}\text { NaOH- } \\
\text { P, } \\
\mu \mathrm{mol} / \mathrm{g}\end{array}$ & $\begin{array}{c}\mathrm{NaOH}- \\
\mathbf{r P}, \\
\mu \mathrm{mol} / \mathrm{g}\end{array}$ & $\begin{array}{c}\text { NaOH- } \\
\text { nrP, } \\
\mu \mathrm{mol} / \mathrm{g}\end{array}$ & $\begin{array}{c}\mathrm{NaOH}- \\
\text { rP:P }\end{array}$ & $\begin{array}{c}\text { HCl- } \\
\mathrm{P}, \\
\mu \mathrm{mol} / \mathrm{g}\end{array}$ \\
\hline 4330 & $8 / 17 / 10$ & 30.4 & 2.2 & 201.0 & 38.4 & 7.5 & 12.2 & 10.9 & 0.6 & 12.9 & 5.3 & 7.6 & 0.4 & 0.6 \\
\hline 4336 & $8 / 17 / 10$ & 11.5 & 1.4 & 264.0 & 118.0 & 35.0 & 51.7 & 94.2 & 1.3 & 20.9 & 14.4 & 6.5 & 0.7 & 2.1 \\
\hline 4388 & $8 / 15 / 11$ & 18.2 & 2.1 & 347.0 & NA & 34.9 & 66.6 & NA & 0.0 & 25.1 & 12.3 & 12.8 & 0.5 & NA \\
\hline 4452 & $9 / 20 / 12$ & 27.6 & 2.1 & 724.0 & 95.0 & 38.3 & 136.9 & 24.5 & 0.0 & 53.2 & 27.1 & 26.0 & 0.5 & 0.7 \\
\hline 4492 & $8 / 25 / 10$ & 28.8 & 9.4 & 612.0 & 175.0 & 39.0 & 54.5 & 27.1 & 1.0 & 52.8 & 28.2 & 24.6 & 0.5 & 2.3 \\
\hline 4606 & 9/19/12 & 26.7 & 4.6 & 754.0 & 187.0 & 102.3 & 116.0 & 67.8 & 0.0 & 49.3 & 26.3 & 22.9 & 0.5 & 0.8 \\
\hline 4608 & $9 / 19 / 12$ & 26.0 & 3.1 & 604.0 & 217.0 & 144.3 & 147.2 & 68.4 & 0.0 & 53.0 & 33.0 & 20.1 & 0.6 & 1.7 \\
\hline 4610 & $9 / 20 / 12$ & 36.4 & 3.8 & 677.0 & 69.0 & 25.1 & 39.5 & 20.8 & 0.0 & 39.4 & 19.2 & 20.2 & 0.5 & 0.6 \\
\hline 4612 & $9 / 20 / 12$ & 26.0 & 2.6 & 677.0 & 120.0 & 19.9 & 40.9 & 35.8 & 0.0 & 51.0 & 33.1 & 18.0 & 0.7 & 2.5 \\
\hline 4614 & $9 / 17 / 12$ & 42.3 & 2.2 & 169.0 & 44.0 & 11.0 & 11.2 & 16.0 & 0.6 & 17.0 & 6.0 & 10.1 & 0.4 & 0.6 \\
\hline 4618 & $9 / 20 / 12$ & 47.0 & 2.8 & 269.0 & 52.0 & 15.5 & 13.9 & 16.5 & 0.9 & 27.2 & 10.1 & 17.1 & 0.4 & 0.4 \\
\hline 4620 & $9 / 17 / 12$ & 50.9 & 2.3 & 186.0 & 41.0 & 8.6 & 7.3 & 12.6 & 0.0 & 14.8 & 4.4 & 10.4 & 0.3 & 0.7 \\
\hline 4622 & $9 / 19 / 12$ & 16.6 & 1.7 & 347.0 & 168.0 & 51.0 & 85.6 & 63.0 & 0.0 & 32.0 & 16.1 & 15.9 & 0.5 & 2.8 \\
\hline 4624 & $9 / 17 / 12$ & 19.2 & 1.4 & 328.0 & 171.0 & 35.0 & 73.0 & 47.1 & 0.0 & 28.1 & 13.5 & 14.6 & 0.5 & 1.7 \\
\hline 4628 & $9 / 17 / 12$ & 26.1 & 2.6 & 488.0 & 127.0 & 17.5 & 20.4 & 43.1 & 0.0 & 38.4 & 19.6 & 18.8 & 0.5 & 2.1 \\
\hline 4630 & $9 / 17 / 12$ & 20.3 & 2.7 & 452.0 & 164.0 & 36.2 & 100.7 & 52.0 & 0.0 & 24.5 & 12.8 & 11.7 & 0.5 & 0.8 \\
\hline 4766 & $8 / 25 / 10$ & 27.8 & 1.8 & 383.0 & 161.0 & 39.6 & 164.0 & 35.1 & 1.0 & 47.4 & 22.3 & 25.1 & 0.5 & 2.6 \\
\hline 4782 & $9 / 8 / 11$ & 33.2 & 1.9 & 295.0 & 141.0 & 12.3 & 18.4 & 18.4 & 0.0 & 23.2 & 7.2 & 16.0 & 0.3 & 1.9 \\
\hline 4788 & $8 / 25 / 10$ & 18.6 & 0.5 & 199.0 & 144.0 & 19.7 & 18.4 & 21.4 & 0.6 & 23.6 & 11.0 & 12.6 & 0.5 & 2.4 \\
\hline 4800 & $9 / 1 / 10$ & 25.2 & 9.2 & 254.0 & 109.0 & 25.4 & 37.9 & 42.1 & 1.4 & 24.1 & 10.8 & 13.2 & 0.5 & 1.3 \\
\hline 4802 & $8 / 10 / 11$ & 25.5 & 2.5 & 257.0 & 134.0 & 23.7 & 41.3 & 57.0 & 0.0 & 27.8 & 11.0 & 16.8 & 0.4 & 1.1 \\
\hline 4806 & $8 / 10 / 11$ & 16.2 & 0.9 & 239.0 & 202.0 & 38.1 & 46.4 & 81.1 & 0.4 & 27.7 & 13.4 & 14.3 & 0.5 & 2.4 \\
\hline 4822 & $8 / 11 / 11$ & 10.4 & 1.3 & 171.0 & 212.0 & 42.7 & 38.4 & 165.6 & 2.3 & 18.4 & 13.8 & 4.6 & 0.8 & 3.7 \\
\hline 4852 & $8 / 11 / 11$ & 14.5 & 3.9 & 238.0 & 161.0 & 89.2 & 86.7 & 177.2 & 3.0 & 29.7 & 20.4 & 9.3 & 0.7 & 2.3 \\
\hline 4857 & $8 / 24 / 10$ & 21.6 & 13.5 & 448.0 & 168.0 & 18.6 & 68.6 & 77.4 & 1.0 & 28.5 & 12.6 & 15.9 & 0.4 & 5.0 \\
\hline
\end{tabular}


Table B2: Continued

\begin{tabular}{|c|c|c|c|c|c|c|c|c|c|c|c|c|c|c|}
\hline Midas & $\begin{array}{c}\text { Sample } \\
\text { Date }\end{array}$ & $\%$ LOI & $\begin{array}{c}\text { BD- } \\
\text { Al, } \\
\mu \mathrm{mol} / \mathrm{g}\end{array}$ & $\begin{array}{c}\text { NaOH- } \\
\text { Al, } \\
\mu \mathrm{mol} / \mathrm{g}\end{array}$ & $\begin{array}{c}\text { HCl- } \\
\text { Al, } \\
\mu \mathrm{mol} / \mathrm{g} \\
\end{array}$ & $\begin{array}{c}\text { BD- } \\
\text { Fe, } \\
\mu \mathrm{mol} / \mathrm{g} \\
\end{array}$ & $\begin{array}{c}\text { NaOH- } \\
\text { Fe, } \\
\mu \mathrm{mol} / \mathrm{g}\end{array}$ & $\begin{array}{c}\text { HCl- } \\
\text { Fe, } \\
\mu \mathrm{mol} / \mathrm{g}\end{array}$ & $\begin{array}{c}\begin{array}{c}\text { BD- } \\
\text { P, } \\
\mu \mathrm{mol} / \mathrm{g}\end{array} \\
\end{array}$ & $\begin{array}{c}\text { NaOH- } \\
\text { P, } \\
\mu \mathrm{mol} / \mathrm{g}\end{array}$ & $\begin{array}{c}\mathrm{NaOH}- \\
\mathbf{r P}, \\
\mu \mathrm{mol} / \mathrm{g}\end{array}$ & $\begin{array}{c}\text { NaOH- } \\
\text { nrP, } \\
\mu \mathrm{mol} / \mathrm{g}\end{array}$ & $\begin{array}{c}\mathrm{NaOH}- \\
\text { rP:P }\end{array}$ & $\begin{array}{c}\text { HCl- } \\
\mathrm{P}, \\
\mu \mathrm{mol} / \mathrm{g}\end{array}$ \\
\hline 4894 & $8 / 17 / 11$ & 27.1 & 0.9 & 406.0 & 162.0 & 11.0 & 52.0 & 54.0 & 0.7 & 35.1 & 13.6 & 21.5 & 0.4 & 1.8 \\
\hline 4896 & $8 / 31 / 10$ & 19.9 & 14.3 & 256.0 & 191.0 & 89.8 & 76.6 & 105.0 & 4.3 & 31.7 & 20.6 & 11.1 & 0.7 & 2.9 \\
\hline 5024 & $8 / 31 / 11$ & 20.7 & 3.5 & 197.0 & 227.0 & 58.0 & 26.0 & 48.0 & 4.0 & 36.8 & 25.0 & 11.9 & 0.7 & 1.4 \\
\hline 5172 & $8 / 11 / 11$ & 11.9 & 1.5 & 132.0 & NA & 41.0 & 28.0 & - & 2.7 & 23.5 & 14.7 & 8.8 & 0.6 & NA \\
\hline 5174 & $8 / 11 / 11$ & 57.2 & 1.2 & 167.0 & 43.3 & 27.8 & 25.0 & 36.7 & 0.1 & 15.3 & 4.9 & 10.4 & 0.3 & 1.2 \\
\hline 5198 & $8 / 18 / 10$ & 14.6 & 1.9 & 296.0 & 234.0 & 45.0 & 134.0 & 147.0 & 2.4 & 36.5 & 24.1 & 12.4 & 0.7 & 3.9 \\
\hline 5222 & $9 / 6 / 11$ & 10.3 & 5.8 & 204.0 & 302.0 & 50.0 & 55.0 & 236.0 & 1.5 & 21.0 & 16.5 & 4.5 & 0.8 & 3.5 \\
\hline 5236 & $8 / 19 / 10$ & 20.0 & 2.4 & 114.0 & 66.0 & 76.3 & 31.7 & 109.8 & 22.3 & 18.5 & 14.4 & 4.1 & 0.8 & 1.4 \\
\hline 5240 & $9 / 2 / 10$ & 20.7 & 9.6 & 280.0 & 242.0 & 58.4 & 57.6 & 114.0 & 3.0 & 29.2 & 17.4 & 11.7 & 0.6 & 4.5 \\
\hline 5280 & $8 / 9 / 11$ & 18.4 & 6.0 & 304.0 & 237.0 & 84.6 & 80.6 & 138.1 & 4.9 & 37.5 & 26.6 & 10.9 & 0.7 & 4.1 \\
\hline 5344 & $8 / 22 / 11$ & 15.1 & 0.7 & 171.0 & 168.0 & 31.8 & 32.5 & 72.9 & 1.0 & 22.0 & 11.5 & 10.5 & 0.5 & 6.9 \\
\hline 5348 & $8 / 22 / 11$ & 17.1 & 1.1 & 150.0 & 207.0 & 27.0 & 25.0 & 93.0 & 0.8 & 20.8 & 11.7 & 9.1 & 0.6 & 9.5 \\
\hline 5349 & $8 / 22 / 11$ & 14.5 & 0.7 & 125.0 & 170.0 & 35.5 & 22.7 & 93.1 & 1.2 & 12.5 & 6.3 & 6.2 & 0.5 & 7.1 \\
\hline 5352 & $8 / 19 / 10$ & 12.2 & 3.4 & 139.0 & 193.0 & 41.8 & 28.7 & 106.0 & 3.0 & 16.0 & 8.7 & 7.3 & 0.5 & 8.2 \\
\hline 5386 & $9 / 1 / 10$ & 24.6 & 4.3 & 369.0 & 172.0 & 52.1 & 72.8 & 82.7 & 1.9 & 45.8 & 27.6 & 18.2 & 0.6 & 4.9 \\
\hline 5400 & $8 / 31 / 10$ & 11.4 & 5.9 & 368.0 & 198.0 & 50.4 & 115.0 & 131.0 & 2.3 & 30.8 & 22.5 & 8.3 & 0.7 & 3.4 \\
\hline 5408 & $8 / 26 / 10$ & 10.8 & 5.7 & 182.0 & 204.0 & 48.4 & 56.5 & 202.0 & 5.1 & 27.6 & 22.5 & 5.2 & 0.8 & 6.1 \\
\hline 5416 & $8 / 26 / 10$ & NA & NA & NA & NA & NA & NA & NA & NA & NA & NA & NA & NA & NA \\
\hline 5448 & $8 / 26 / 10$ & 8.6 & 1.4 & 50.9 & 198.0 & 40.3 & 1.7 & 168.0 & 2.8 & 7.5 & 3.5 & 4.1 & 0.5 & 8.7 \\
\hline 5458 & $9 / 2 / 10$ & 22.9 & 13.7 & 125.0 & 160.0 & 44.0 & 25.5 & 86.0 & 2.9 & 12.9 & 5.7 & 7.2 & 0.4 & 6.7 \\
\hline 5490 & $8 / 15 / 11$ & 31.0 & 2.2 & 230.0 & 97.0 & 16.0 & 25.4 & 40.8 & 0.0 & 23.5 & 8.5 & 15.1 & 0.4 & 2.1 \\
\hline 5682 & $9 / 1 / 10$ & 12.6 & 4.6 & 271.0 & 170.0 & 50.5 & 90.0 & 137.0 & 2.1 & 30.7 & 21.0 & 9.7 & 0.7 & 3.9 \\
\hline 5690 & $8 / 17 / 11$ & 12.8 & 2.5 & 320.0 & 144.0 & 59.7 & 102.2 & 142.0 & 3.4 & 29.8 & 23.2 & 6.6 & 0.8 & 2.4 \\
\hline 5710 & $8 / 17 / 11$ & 19.3 & 3.1 & 392.0 & 99.0 & 28.0 & 74.4 & 43.0 & 1.5 & 37.1 & 21.3 & 15.8 & 0.6 & 1.2 \\
\hline 5780 & $8 / 30 / 11$ & 15.5 & 1.6 & 328.0 & 157.1 & 40.3 & 55.5 & 64.4 & 0.3 & 42.2 & 27.1 & 15.0 & 0.6 & 7.6 \\
\hline
\end{tabular}


Table B2: Continued

\begin{tabular}{|c|c|c|c|c|c|c|c|c|c|c|c|c|c|c|}
\hline Midas & $\begin{array}{c}\text { Sample } \\
\text { Date }\end{array}$ & \%LOI & $\begin{array}{c}\text { BD- } \\
\text { Al, } \\
\mu \mathrm{mol} / \mathrm{g}\end{array}$ & $\begin{array}{c}\mathrm{NaOH}- \\
\mathrm{Al}, \\
\mu \mathrm{mol} / \mathrm{g}\end{array}$ & $\begin{array}{c}\text { HCl- } \\
\text { Al, } \\
\mu \mathrm{mol} / \mathrm{g}\end{array}$ & $\begin{array}{c}\text { BD- } \\
\mathrm{Fe}, \\
\mu \mathrm{mol} / \mathrm{g}\end{array}$ & $\begin{array}{c}\mathrm{NaOH}- \\
\mathrm{Fe}, \\
\mu \mathrm{mol} / \mathrm{g}\end{array}$ & $\begin{array}{c}\mathrm{HCl}- \\
\mathrm{Fe}, \\
\mu \mathrm{mol} / \mathrm{g}\end{array}$ & $\begin{array}{c}\text { BD- } \\
\text { P, } \\
\mu \mathrm{mol} / \mathrm{g}\end{array}$ & $\begin{array}{c}\mathrm{NaOH}- \\
\mathrm{P}, \\
\mu \mathrm{mol} / \mathrm{g}\end{array}$ & $\begin{array}{c}\mathrm{NaOH}- \\
\mathrm{rP}, \\
\mu \mathrm{mol} / \mathrm{g}\end{array}$ & $\begin{array}{c}\mathrm{NaOH}- \\
\mathrm{nrP}, \\
\mu \mathrm{mol} / \mathrm{g}\end{array}$ & $\begin{array}{c}\mathrm{NaOH}- \\
\text { rP:P }\end{array}$ & $\begin{array}{c}\text { HCl- } \\
\text { P, } \\
\mu \mathrm{mol} / \mathrm{g}\end{array}$ \\
\hline 5814 & $8 / 18 / 11$ & 24.0 & 2.4 & 258.0 & 242.0 & 81.0 & 74.6 & 117.2 & 3.5 & 43.8 & 29.1 & 14.7 & 0.7 & 3.0 \\
\hline 9685 & $8 / 16 / 11$ & 10.3 & 1.1 & 188.0 & NA & 18.1 & 23.9 & NA & 0.0 & 23.3 & 12.5 & 10.8 & 0.5 & NA \\
\hline 9931 & $8 / 31 / 10$ & 12.2 & 3.6 & 201.0 & 166.0 & 57.6 & 40.0 & 116.0 & 4.0 & 28.6 & 18.2 & 10.4 & 0.6 & 7.8 \\
\hline
\end{tabular}


Table B3: Sediment Calcium Fractionation $(0-2 ; 8-10 \mathrm{~cm})$. Data reports the surface short cores $(0-2 \mathrm{~cm})$ and bottom short core $(8-10$ $\mathrm{cm})$ taken from the 24 lakes (2015) and the 18 chain lakes (2016). The DEP and LEA did not provide the calcium fraction analysis.

\begin{tabular}{|c|c|c|c|c|c|c|c|c|}
\hline Lake Study & Midas & $\begin{array}{c}\text { Sample } \\
\text { Date }\end{array}$ & $\begin{array}{l}\text { BD-Ca, } \\
\mu \mathrm{mol} / \mathrm{g}\end{array}$ & $\begin{array}{c}\mathrm{NaOH}-\mathrm{Ca}, \\
\mu \mathrm{mol} / \mathrm{g}\end{array}$ & $\begin{array}{c}\mathrm{HCl}-\mathrm{Ca}, \\
\mu \mathrm{mol} / \mathrm{g}\end{array}$ & $\begin{array}{l}\text { BD-Ca, } \\
\mu \mathrm{mol} / \mathrm{g}\end{array}$ & $\begin{array}{c}\mathrm{NaOH}-\mathrm{Ca}, \\
\mu \mathrm{mol} / \mathrm{g}\end{array}$ & $\begin{array}{r}\mathrm{HCl}-\mathrm{Ca}, \\
\mu \mathrm{mol} / \mathrm{g}\end{array}$ \\
\hline & & & $0-2 \mathrm{~cm}$ & $0-2 \mathrm{~cm}$ & $0-2 \mathrm{~cm}$ & $8-10 \mathrm{~cm}$ & $8-10 \mathrm{~cm}$ & $8-10 \mathrm{~cm}$ \\
\hline \multirow[t]{23}{*}{2015} & 3748 & $6 / 26 / 15$ & 39.3 & 1.8 & 23.0 & 26.2 & NA & 25.3 \\
\hline & 5448 & $6 / 24 / 15$ & 52.8 & 2.9 & 29.6 & 34.7 & 1.3 & 21.9 \\
\hline & 5190 & $7 / 8 / 15$ & 58.9 & 5.1 & 13.4 & 58.1 & 3.0 & 16.1 \\
\hline & 5400 & $7 / 13 / 15$ & 30.6 & 4.2 & 10.7 & 20.2 & 2.8 & 10.9 \\
\hline & 5349 & $6 / 25 / 15$ & 42.5 & 1.6 & 6.8 & 27.6 & 1.6 & 17.8 \\
\hline & 78 & $7 / 9 / 15$ & 40.9 & 4.9 & 8.3 & 52.1 & 3.6 & 17.4 \\
\hline & 5274 & $7 / 6 / 15$ & 49.8 & 3.3 & 16.5 & 34.5 & 2.2 & 16.9 \\
\hline & 4538 & $7 / 10 / 15$ & 46.3 & 7.6 & 10.7 & 48.5 & 6.2 & 20.4 \\
\hline & 5272 & $7 / 6 / 15$ & 84.0 & 5.8 & 19.9 & 47.8 & 3.4 & 16.0 \\
\hline & 5348 & $7 / 2 / 15$ & 122.8 & 5.9 & 22.8 & 64.7 & 3.9 & 32.3 \\
\hline & 177 & $6 / 30 / 15$ & 14.4 & 2.1 & 11.2 & 12.2 & NA & 20.5 \\
\hline & 5280 & $7 / 2 / 15$ & 65.9 & 7.8 & 11.1 & 46.4 & 4.4 & 20.6 \\
\hline & 3838 & $6 / 29 / 15$ & 81.7 & 9.5 & 5.2 & 52.4 & 6.6 & 17.1 \\
\hline & 5344 & $6 / 25 / 15$ & 24.9 & 2.5 & 8.2 & 32.6 & 0.3 & 19.5 \\
\hline & 224 & $7 / 8 / 15$ & 48.1 & 4.4 & 10.8 & 36.4 & 0.3 & 15.9 \\
\hline & 3446 & $7 / 7 / 15$ & 48.3 & 3.4 & 10.8 & 46.1 & 3.0 & 19.1 \\
\hline & 3796 & $6 / 26 / 15$ & 71.3 & 1.8 & 10.3 & 42.0 & NA & 21.4 \\
\hline & 5352 & $7 / 2 / 15$ & 56.1 & NA & 16.7 & 44.0 & 1.9 & 20.7 \\
\hline & 3916 & $6 / 29 / 15$ & 61.9 & 5.5 & 10.8 & 39.8 & NA & 11.0 \\
\hline & 3750 & $7 / 9 / 15$ & 73.8 & 3.4 & 27.4 & 54.7 & 1.4 & 34.5 \\
\hline & 3444 & $7 / 7 / 15$ & 60.7 & 0.8 & 10.6 & 40.6 & 1.3 & 15.4 \\
\hline & 4434 & $6 / 30 / 15$ & 26.3 & 2.8 & 10.0 & 34.3 & 6.2 & 9.5 \\
\hline & 5172 & $7 / 1 / 15$ & 41.2 & 1.4 & 24.1 & 38.4 & 2.5 & 22.2 \\
\hline
\end{tabular}


Table B3: Continued

\begin{tabular}{|c|c|c|c|c|c|c|c|c|}
\hline Lake Study & Midas & $\begin{array}{c}\text { Sample } \\
\text { Date }\end{array}$ & $\begin{array}{l}\text { BD-Ca, } \\
\mu \mathrm{mol} / \mathrm{g}\end{array}$ & $\begin{array}{c}\mathrm{NaOH}-\mathrm{Ca}, \\
\mu \mathrm{mol} / \mathrm{g}\end{array}$ & $\begin{array}{c}\mathrm{HCl}-\mathrm{Ca}, \\
\mu \mathrm{mol} / \mathrm{g}\end{array}$ & $\begin{array}{l}\text { BD-Ca, } \\
\mu \mathrm{mol} / \mathrm{g}\end{array}$ & $\begin{array}{c}\mathrm{NaOH}-\mathrm{Ca}, \\
\mu \mathrm{mol} / \mathrm{g}\end{array}$ & $\begin{array}{c}\mathrm{HCl}-\mathrm{Ca}, \\
\mu \mathrm{mol} / \mathrm{g}\end{array}$ \\
\hline & 5408 & $6 / 24 / 15$ & 49.4 & NA & 16.5 & 31.1 & 0.8 & 16.3 \\
\hline \multirow[t]{18}{*}{2016} & 4444 & $6 / 24 / 16$ & 28.4 & 3.8 & 15.1 & 24.1 & 2.9 & 15.5 \\
\hline & 5666 & $6 / 28 / 16$ & 101.6 & 8.6 & 19.0 & 74.7 & 9.6 & 20.9 \\
\hline & 5814 & $6 / 23 / 16$ & 70.0 & 7.8 & 14.6 & 62.5 & 7.4 & 21.5 \\
\hline & 5182 & $6 / 23 / 16$ & 62.0 & 8.1 & 17.3 & 43.3 & 6.8 & 21.8 \\
\hline & 4406 & $6 / 27 / 16$ & 32.7 & 4.0 & 11.2 & 29.3 & 2.8 & 10.0 \\
\hline & 5330 & $6 / 29 / 16$ & 43.6 & 7.4 & 12.8 & 42.3 & 7.5 & 13.2 \\
\hline & 5664 & $6 / 30 / 16$ & 77.0 & 5.9 & 21.4 & 76.0 & 8.4 & 30.3 \\
\hline & 3760 & $6 / 22 / 16$ & 99.2 & 8.2 & 18.6 & 76.7 & 6.7 & 25.4 \\
\hline & 3762 & $6 / 22 / 16$ & 108.7 & 8.3 & 22.4 & 70.1 & 5.5 & 21.6 \\
\hline & 5812 & $6 / 29 / 16$ & 67.4 & 10.9 & 17.3 & 52.2 & 9.1 & 24.2 \\
\hline & 4448 & $6 / 24 / 16$ & 12.4 & 3.0 & 6.7 & 15.2 & 2.7 & 12.8 \\
\hline & 5186 & $6 / 29 / 16$ & 74.6 & 6.5 & 17.9 & 60.2 & 6.2 & 22.8 \\
\hline & 3826 & $6 / 30 / 16$ & 105.1 & 8.1 & 12.6 & 94.3 & 8.1 & 11.9 \\
\hline & 3824 & $6 / 30 / 16$ & 54.0 & 3.5 & 21.7 & 41.5 & 4.0 & 29.8 \\
\hline & 4446 & $6 / 27 / 16$ & 119.3 & 13.0 & 13.4 & 111.4 & 11.5 & 18.5 \\
\hline & 3688 & $6 / 23 / 16$ & 122.7 & 8.6 & 19.0 & 81.5 & 4.8 & 21.7 \\
\hline & 4346 & $6 / 24 / 16$ & 31.2 & 3.9 & 12.9 & 23.2 & 3.7 & 13.8 \\
\hline & 5184 & $6 / 28 / 16$ & 247.4 & 13.2 & 25.1 & 158.8 & 11.2 & 27.5 \\
\hline
\end{tabular}


Figure B1: Sequential Extraction (P, Fe, Al) of Sediment Cores. Reported date includes summer 2015 in $\mu$ mol g ${ }^{-1}$ dry weight (dw) at depth $(0-2 ; 8-10 \mathrm{~cm})$.
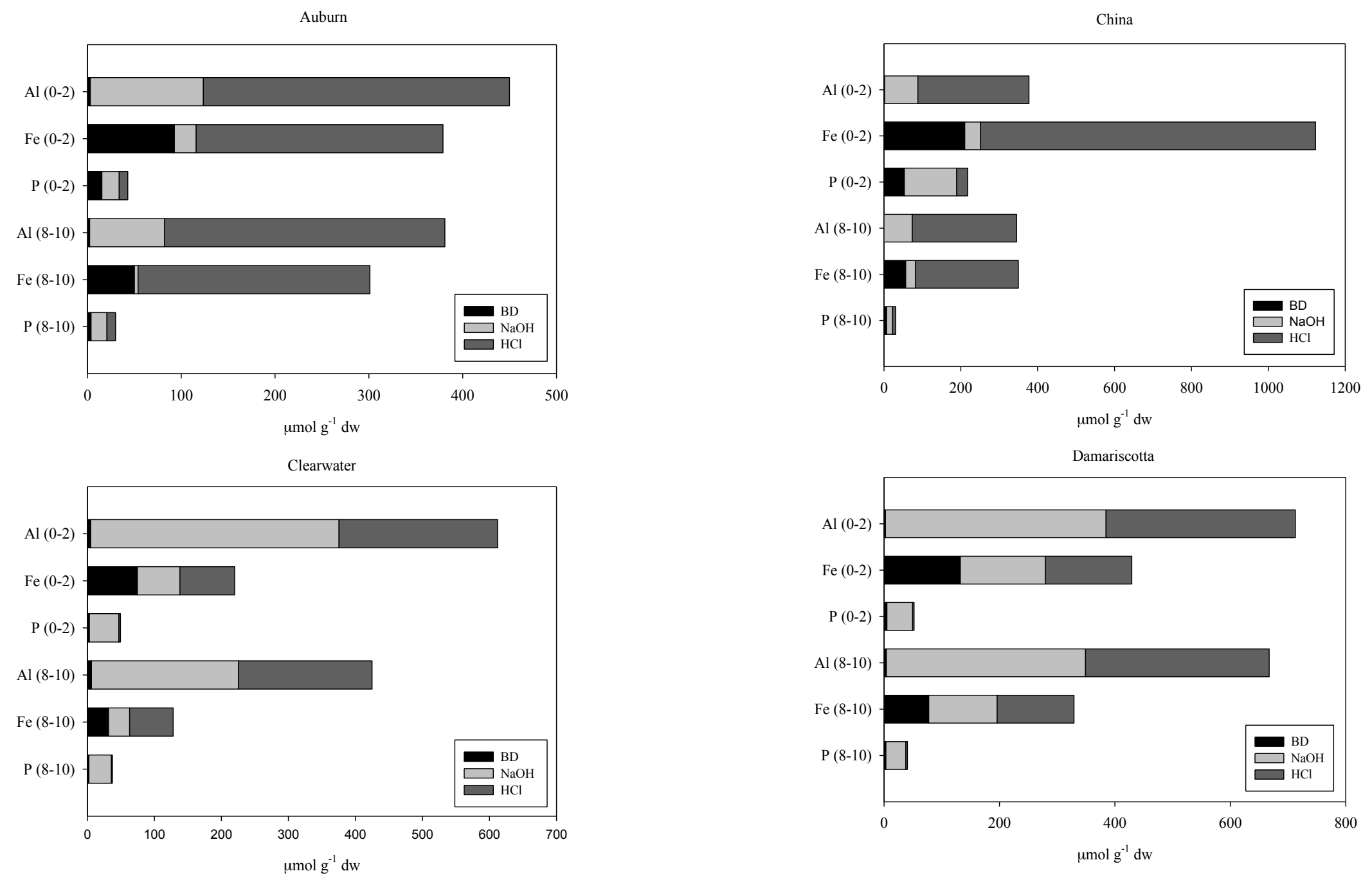
Figure B1: Continued

East

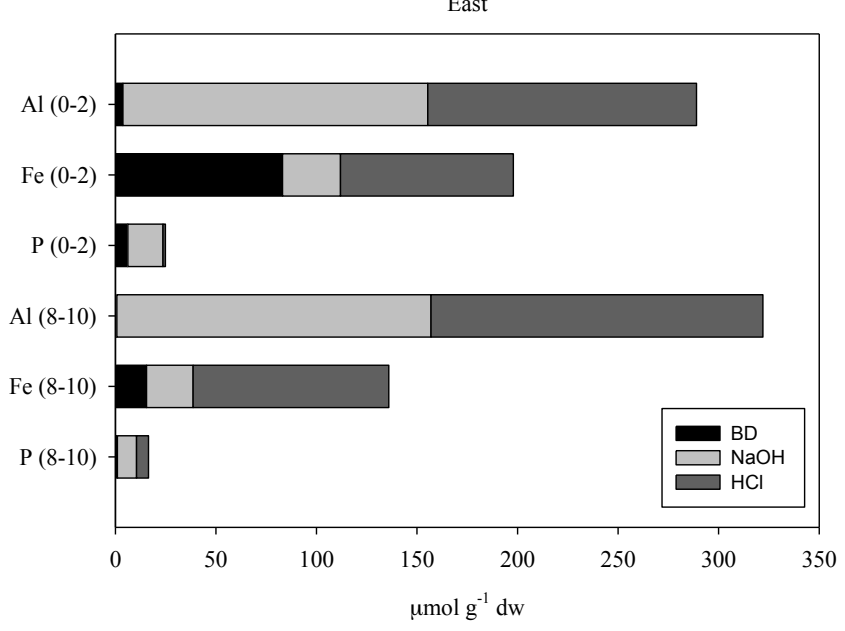

Great

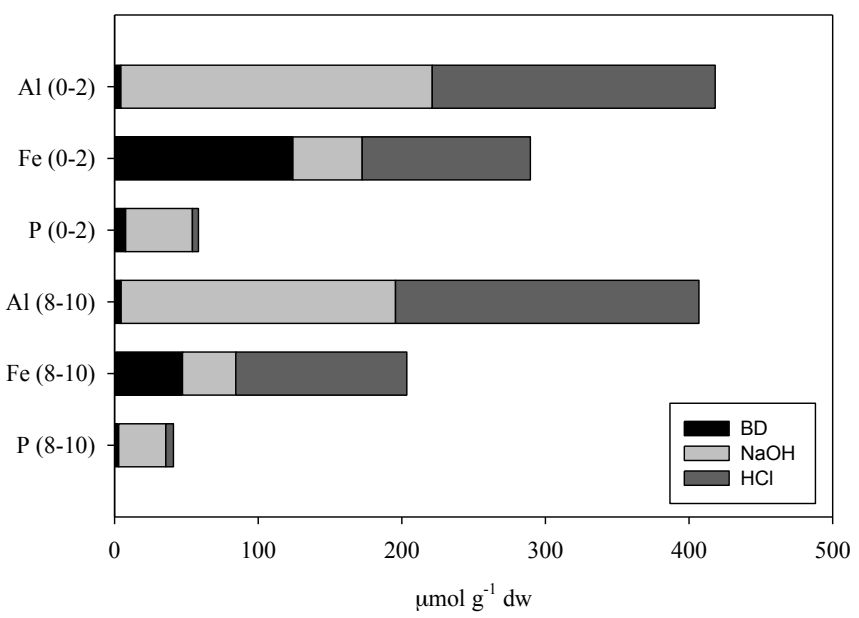

Embden
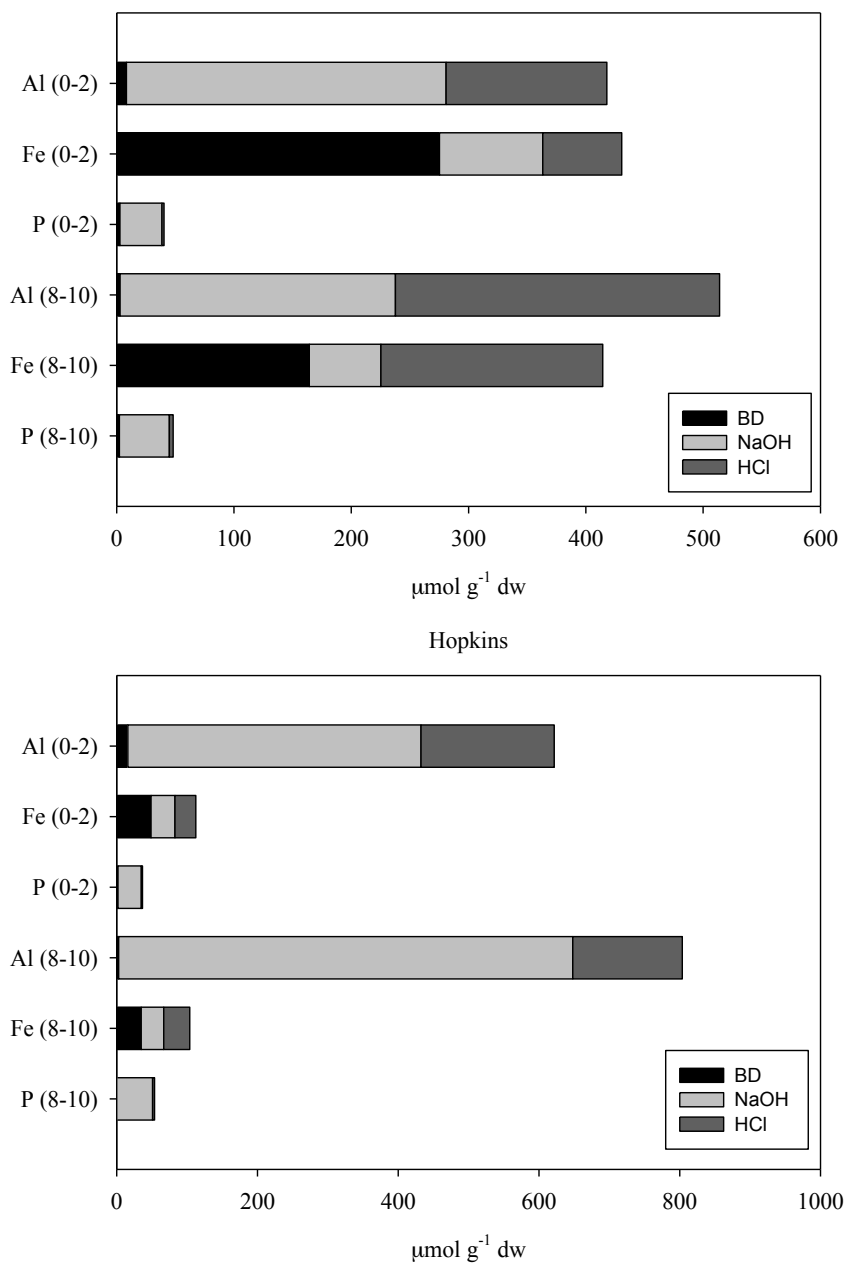
Figure B1: Continued

Long

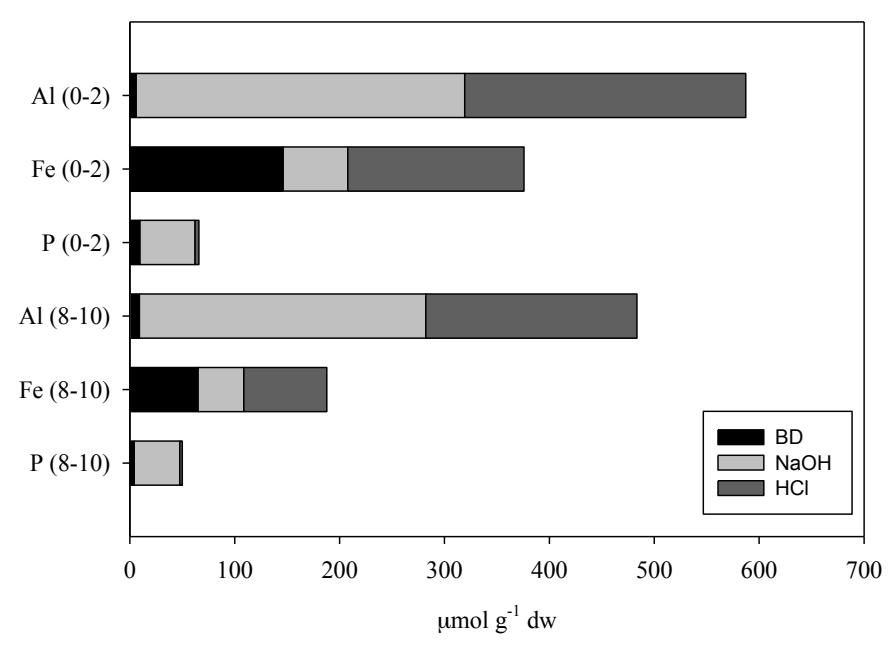

Meddybemps

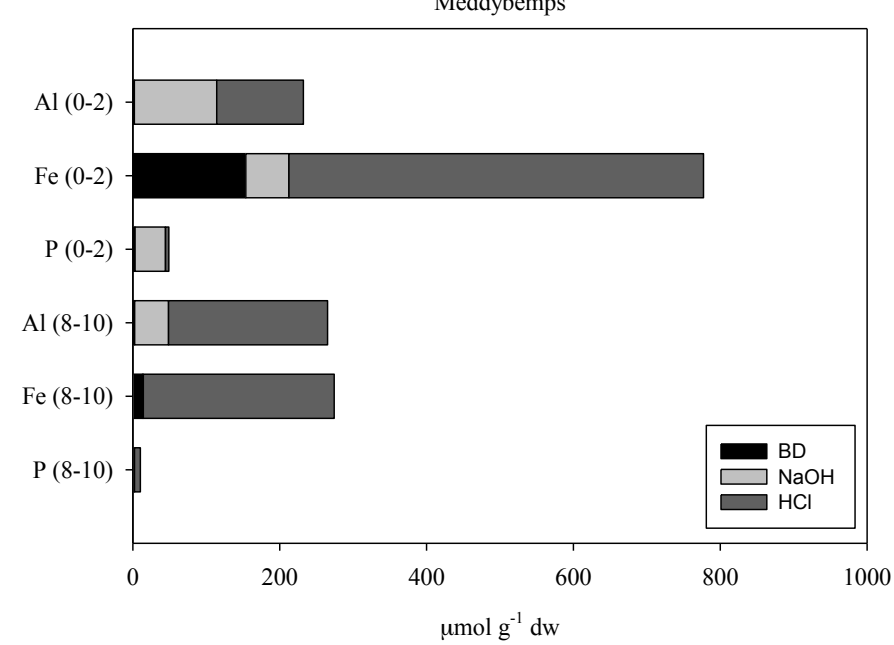

McGrath

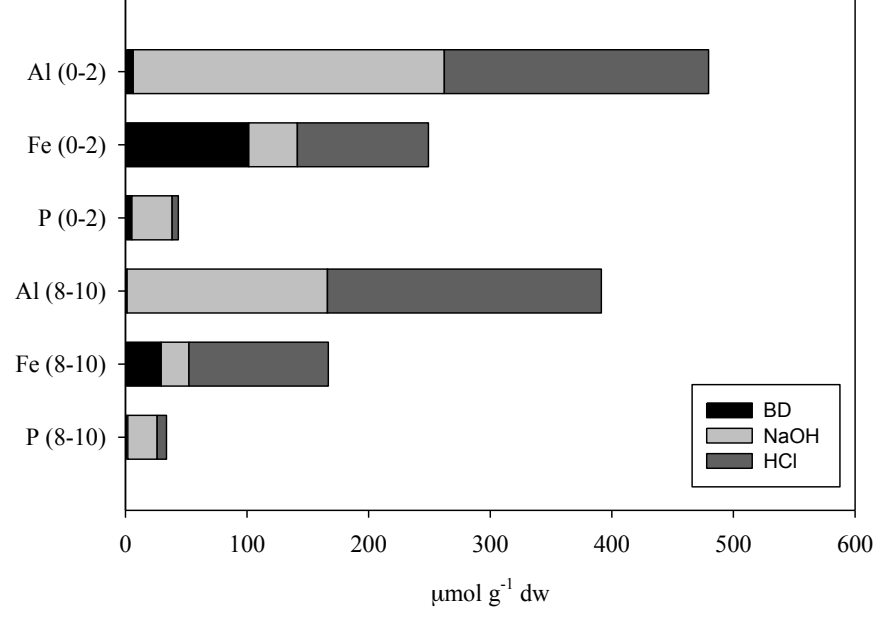

Messalonskee

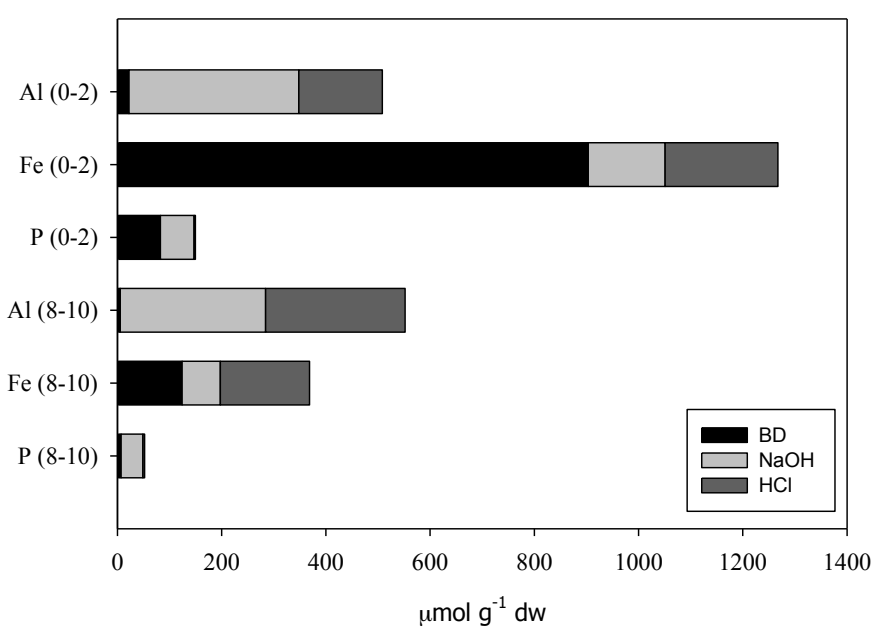


Figure B1: Continued
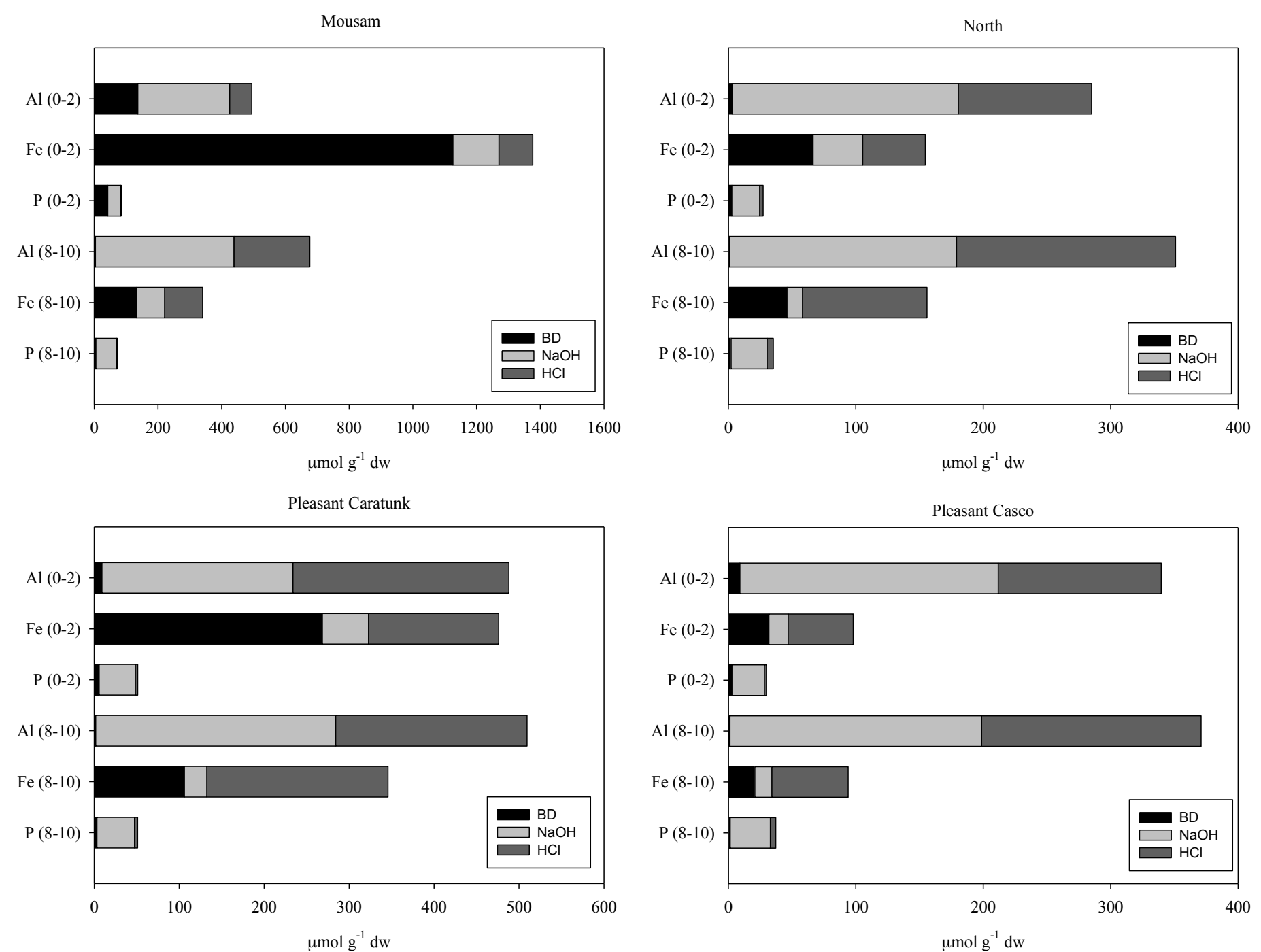
Figure B1: Continued
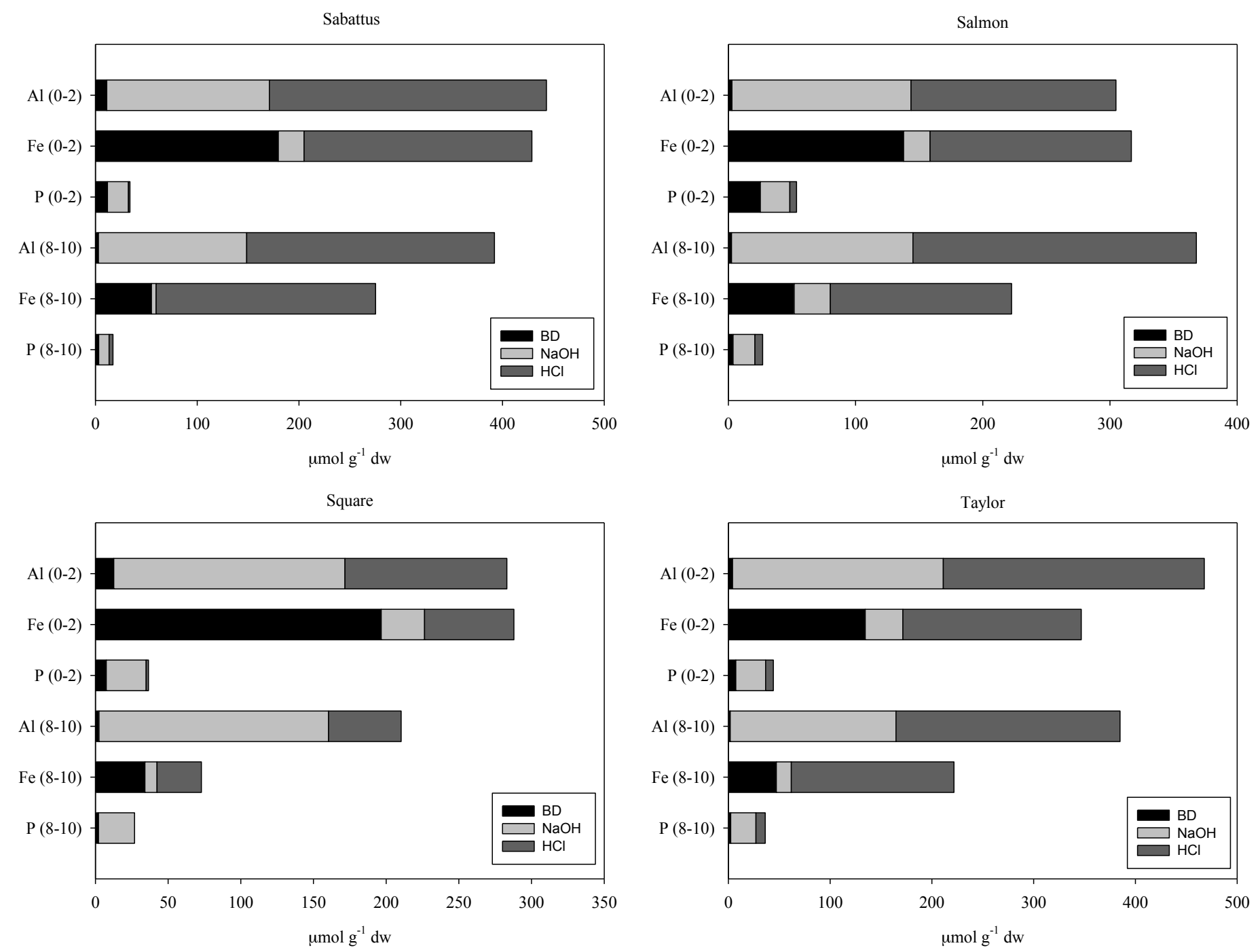
Figure B1: Continued
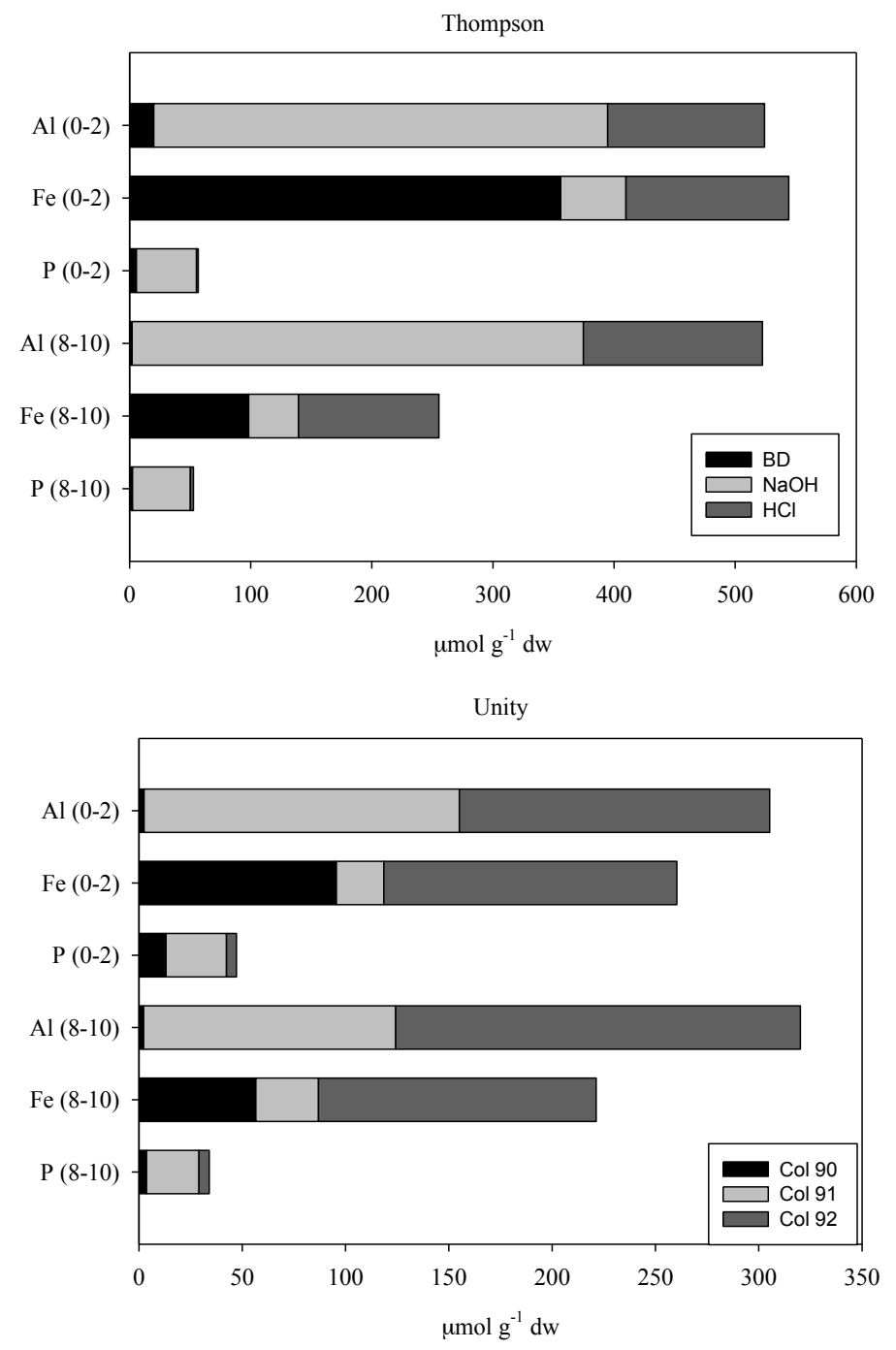
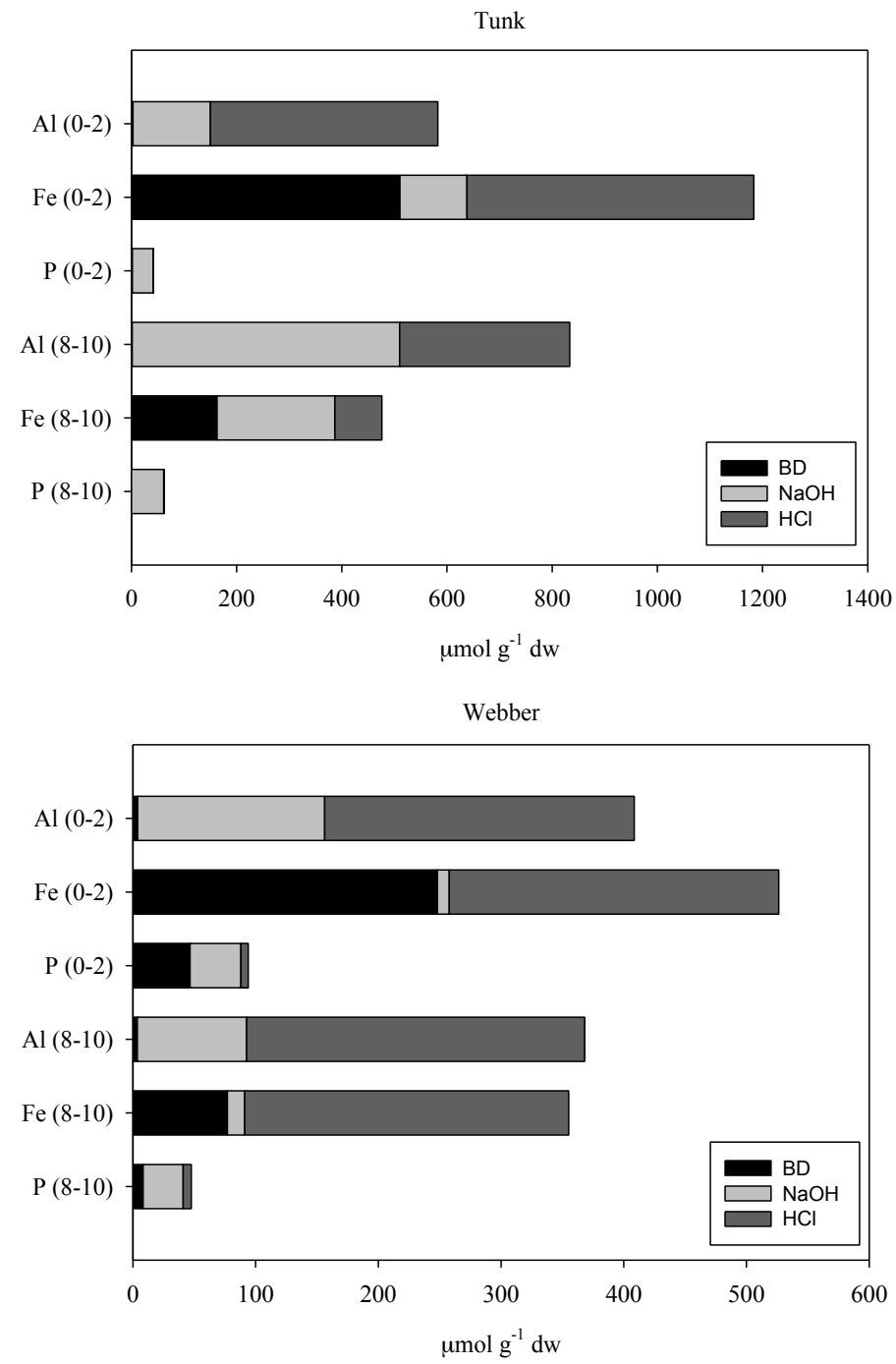
Table B4: Cations and Secchi Transparency. Results include epilimnetic Total Al, Fe, Mg, Ca, Na, K, and secchi for all samples in this study.

\begin{tabular}{|c|c|c|c|c|c|c|c|c|}
\hline Midas & Date & $\mathbf{A l}, \mathbf{u g} / \mathbf{L}$ & Fe, ug/L & $\mathrm{Mg}, \mathrm{mg} / \mathrm{L}$ & $\mathrm{Ca}, \mathrm{mg} / \mathrm{L}$ & $\mathrm{Na}, \mathrm{mg} / \mathrm{L}$ & $\mathbf{K}, \mathbf{m g} / \mathbf{L}$ & Secchi, m \\
\hline \multicolumn{9}{|l|}{2015} \\
\hline 78 & $8 / 25 / 15$ & 10.98 & 6.74 & 0.40 & 2.50 & 1.11 & 0.36 & 9.81 \\
\hline 177 & $8 / 14 / 15$ & 14.21 & 19.05 & 0.35 & 1.61 & 1.99 & 0.21 & 6.25 \\
\hline 224 & $8 / 25 / 15$ & 6.75 & 3.17 & 0.83 & 1.56 & 0.54 & 0.18 & 15.98 \\
\hline 3444 & $8 / 12 / 15$ & 8.83 & 7.10 & 0.50 & 2.80 & 3.45 & 0.37 & 10.35 \\
\hline 3446 & $8 / 20 / 15$ & 5.44 & 6.25 & 0.53 & 2.88 & 5.39 & 0.39 & 5.10 \\
\hline 3748 & $8 / 27 / 15$ & 5.23 & 16.76 & 0.78 & 4.83 & 5.64 & 0.63 & 8.67 \\
\hline 3750 & $8 / 20 / 15$ & 6.52 & 28.97 & 0.88 & 6.22 & 6.37 & 0.72 & 5.50 \\
\hline 3796 & $8 / 12 / 15$ & 22.01 & 261.56 & 1.49 & 8.14 & 6.09 & 1.09 & 1.85 \\
\hline 3838 & $8 / 24 / 25$ & 4.47 & 17.07 & 0.80 & 3.79 & 6.12 & 0.60 & 7.80 \\
\hline 3916 & $8 / 24 / 25$ & 2.72 & 34.45 & 0.99 & 3.85 & 6.76 & 0.50 & 7.50 \\
\hline 4434 & $8 / 14 / 15$ & 31.83 & 3.58 & 0.21 & 0.55 & 1.57 & 0.21 & 10.90 \\
\hline 4538 & $8 / 26 / 15$ & 14.19 & 3.57 & 0.28 & 1.28 & 1.11 & 0.23 & 5.95 \\
\hline 5172 & $8 / 11 / 15$ & 7.40 & 56.37 & 1.17 & 5.30 & 2.72 & 0.62 & 1.33 \\
\hline 5190 & $8 / 18 / 15$ & 7.67 & 9.17 & 0.66 & 3.00 & 1.53 & 0.37 & 9.91 \\
\hline 5272 & $8 / 19 / 15$ & 3.91 & 8.20 & 0.55 & 3.10 & 3.05 & 0.44 & 7.34 \\
\hline 5274 & $8 / 19 / 15$ & 4.25 & 9.15 & 0.61 & 3.17 & 3.09 & 0.46 & 7.05 \\
\hline 5280 & $8 / 13 / 15$ & 5.22 & 45.99 & 1.06 & 5.54 & 3.71 & 0.55 & 5.35 \\
\hline 5344 & $8 / 13 / 15$ & 47.15 & 80.44 & 0.67 & 3.21 & 3.77 & 0.43 & 4.65 \\
\hline 5348 & $8 / 11 / 15$ & 13.43 & 27.01 & 0.82 & 9.17 & 4.21 & 0.88 & 6.10 \\
\hline 5349 & $8 / 18 / 15$ & 6.15 & 24.69 & 0.56 & 3.09 & 2.89 & 0.37 & 5.34 \\
\hline 5352 & $8 / 13 / 15$ & 5.69 & 45.83 & 1.06 & 8.84 & 4.10 & 0.75 & 5.10 \\
\hline 5400 & $8 / 28 / 15$ & 5.23 & 19.33 & 0.67 & 2.41 & 3.85 & 1.01 & 6.25 \\
\hline 5408 & $8 / 10 / 15$ & 5.65 & 52.98 & 0.87 & 5.85 & 3.87 & 0.92 & 2.25 \\
\hline
\end{tabular}


Table B4: Continued

\begin{tabular}{|c|c|c|c|c|c|c|c|c|}
\hline Midas & Date & Al, ug/L & Fe, ug/L & Mg, mg/L & $\mathrm{Ca}, \mathrm{mg} / \mathrm{L}$ & $\mathrm{Na}, \mathrm{mg} / \mathrm{L}$ & $\mathrm{K}, \mathrm{mg} / \mathrm{L}$ & Secchi, m \\
\hline 5448 & $8 / 10 / 15$ & 3.34 & 12.93 & 1.03 & 7.84 & 4.65 & 1.04 & 1.80 \\
\hline \multicolumn{9}{|l|}{2016} \\
\hline 4444 & $8 / 12 / 16$ & 16.59 & 61.75 & 0.57 & 1.47 & 2.68 & 0.43 & 5.03 \\
\hline 5666 & $8 / 8 / 16$ & 14.24 & 53.86 & 0.71 & 3.83 & 3.78 & 0.76 & 4.90 \\
\hline 5814 & $8 / 8 / 16$ & 14.12 & 21.12 & 0.71 & 4.76 & 3.81 & 0.90 & 8.60 \\
\hline 5182 & $8 / 10 / 16$ & 14.13 & 54.26 & 0.73 & 5.33 & 4.55 & 0.73 & 6.35 \\
\hline 4406 & $9 / 2 / 16$ & 6.29 & 206.29 & 0.75 & 2.38 & 3.40 & 0.71 & 2.70 \\
\hline 5330 & $8 / 10 / 16$ & 23.03 & 71.34 & 0.38 & 1.61 & 1.84 & 0.38 & 4.78 \\
\hline 5664 & $8 / 26 / 16$ & 8.03 & 44.61 & 1.07 & 5.86 & 6.42 & 0.77 & 5.85 \\
\hline 3760 & $8 / 23 / 16$ & 14.79 & 93.97 & 0.81 & 6.03 & 4.02 & 0.68 & 6.30 \\
\hline 3762 & $8 / 26 / 16$ & 9.46 & 22.10 & 1.04 & 5.87 & 6.35 & 0.70 & 6.60 \\
\hline 5812 & $8 / 23 / 16$ & 12.12 & 34.57 & 0.77 & 5.73 & 4.77 & 0.77 & 6.78 \\
\hline 4448 & $9 / 1 / 16$ & 24.17 & 30.05 & 0.49 & 1.61 & 2.81 & 0.72 & 7.59 \\
\hline 5186 & $8 / 11 / 16$ & 13.80 & 13.53 & 0.63 & 3.79 & 2.77 & 0.62 & 7.60 \\
\hline 3826 & $8 / 26 / 16$ & 7.29 & 129.66 & 0.81 & 6.27 & 4.30 & 0.99 & 2.20 \\
\hline 3824 & $8 / 11 / 16$ & 6.67 & 42.99 & 0.76 & 5.89 & 4.00 & 0.75 & 5.60 \\
\hline 4446 & $9 / 1 / 16$ & 26.16 & 295.05 & 0.70 & 1.85 & 3.13 & 0.22 & 2.50 \\
\hline 3688 & $8 / 26 / 16$ & 4.71 & 16.96 & 1.00 & 5.65 & 4.81 & 0.68 & 7.21 \\
\hline 4346 & $9 / 1 / 16$ & 80.21 & 184.47 & 0.62 & 1.32 & 3.37 & 0.56 & 4.20 \\
\hline 5184 & $8 / 11 / 16$ & 21.32 & 36.53 & 0.66 & 5.05 & 1.32 & 0.43 & 4.90 \\
\hline \multicolumn{9}{|l|}{ DEP } \\
\hline 70 & $8 / 9 / 11$ & 5.00 & 11.00 & 1.36 & 5.68 & 3.81 & 0.72 & 5.05 \\
\hline 80 & $8 / 24 / 11$ & 19.00 & 47.00 & 1.25 & 6.07 & 4.63 & 0.48 & 4.25 \\
\hline 121 & $8 / 24 / 11$ & 5.00 & 12.00 & 0.53 & 3.68 & 1.21 & 0.26 & 6.16 \\
\hline 177 & $9 / 23 / 10$ & 5.00 & 17.00 & 0.56 & 2.26 & 3.45 & 0.27 & 6.40 \\
\hline 243 & $9 / 1 / 11$ & 29.00 & 11.00 & 0.37 & 1.78 & 0.78 & 0.25 & 6.66 \\
\hline
\end{tabular}


Table B4: Continued

\begin{tabular}{|c|c|c|c|c|c|c|c|c|}
\hline Midas & Date & Al, ug/L & Fe, ug/L & Mg, mg/L & $\mathrm{Ca}, \mathrm{mg} / \mathrm{L}$ & $\mathrm{Na}, \mathrm{mg} / \mathrm{L}$ & $\mathrm{K}, \mathrm{mg} / \mathrm{L}$ & Secchi, m \\
\hline 262 & $8 / 30 / 10$ & 10.00 & 12.00 & 0.51 & 1.42 & 1.53 & 0.27 & 6.56 \\
\hline 342 & $9 / 1 / 11$ & 12.00 & 7.00 & 0.75 & 2.37 & 0.80 & 0.34 & 7.55 \\
\hline 386 & $8 / 23 / 11$ & 13.00 & 20.00 & 0.66 & 2.38 & 2.18 & 0.42 & 2.47 \\
\hline 410 & $9 / 1 / 11$ & 5.00 & 30.00 & 0.85 & 2.64 & 0.81 & 0.41 & 3.45 \\
\hline 447 & $9 / 23 / 12$ & 24.00 & 70.00 & 2.08 & 2.53 & 16.20 & 0.43 & 1.46 \\
\hline 760 & $8 / 30 / 10$ & 5.00 & 15.00 & 1.99 & 8.83 & 1.56 & 0.31 & 4.83 \\
\hline 954 & $8 / 23 / 10$ & 43.00 & 15.00 & 0.40 & 1.55 & 1.38 & 0.28 & 6.84 \\
\hline 1068 & $8 / 24 / 11$ & 5.00 & 2.50 & 0.59 & 3.80 & 2.59 & 0.36 & 6.56 \\
\hline 1070 & $8 / 24 / 11$ & 5.00 & 2.50 & 0.59 & 4.22 & 1.29 & 0.28 & 7.85 \\
\hline 1078 & $8 / 22 / 11$ & 43.00 & 40.00 & 0.42 & 1.56 & 1.61 & 0.19 & 4.67 \\
\hline 1088 & $8 / 22 / 11$ & 29.00 & 16.00 & 0.41 & 1.49 & 1.69 & 0.18 & 6.32 \\
\hline 1150 & $9 / 23 / 10$ & 5.00 & 2.50 & 0.41 & 1.98 & 1.35 & 0.33 & 9.14 \\
\hline 1210 & $8 / 25 / 10$ & 58.00 & 41.00 & 0.37 & 1.25 & 3.06 & 0.33 & 5.69 \\
\hline 2004 & $8 / 23 / 10$ & 11.00 & 2.50 & 0.35 & 1.93 & 1.07 & 0.28 & 6.55 \\
\hline 2020 & $8 / 15 / 11$ & 22.00 & 15.00 & 0.37 & 2.38 & 1.20 & 0.48 & 5.98 \\
\hline 2146 & $8 / 17 / 11$ & 14.00 & 9.00 & 0.47 & 2.27 & 1.84 & 0.35 & 7.61 \\
\hline 2156 & $8 / 24 / 11$ & 5.00 & 31.00 & 1.90 & 11.70 & 2.74 & 0.69 & 3.02 \\
\hline 2242 & $8 / 17 / 11$ & 5.00 & 6.00 & 0.51 & 11.00 & 2.72 & 0.54 & 8.33 \\
\hline 2286 & $9 / 2 / 10$ & 5.00 & 58.00 & 2.04 & 9.14 & 7.31 & 0.43 & 1.68 \\
\hline 2590 & $8 / 30 / 10$ & 5.00 & 27.00 & 1.08 & 4.67 & 1.77 & 0.46 & 5.50 \\
\hline 2608 & $8 / 30 / 10$ & 5.00 & 11.00 & 0.93 & 3.57 & 1.74 & 0.46 & 7.72 \\
\hline 2948 & $8 / 30 / 10$ & 15.00 & 34.00 & 0.82 & 4.06 & 1.00 & 0.29 & 5.85 \\
\hline 3038 & $8 / 24 / 11$ & 31.00 & 32.00 & 0.82 & 3.28 & 0.88 & 0.24 & 5.21 \\
\hline 3376 & $8 / 25 / 11$ & 33.00 & 19.00 & 0.49 & 2.26 & 2.67 & 0.35 & 4.34 \\
\hline 3388 & $9 / 7 / 10$ & 5.00 & 9.00 & 0.65 & 2.87 & 5.75 & 0.50 & 5.69 \\
\hline 3434 & $9 / 1 / 10$ & 5.00 & 5.00 & 0.74 & 5.58 & 5.50 & 0.84 & 5.56 \\
\hline
\end{tabular}


Table B4: Continued

\begin{tabular}{|c|c|c|c|c|c|c|c|c|}
\hline Midas & Date & Al, ug/L & Fe, ug/L & Mg, mg/L & $\mathrm{Ca}, \mathrm{mg} / \mathrm{L}$ & $\mathrm{Na}, \mathrm{mg} / \mathrm{L}$ & $\mathrm{K}, \mathrm{mg} / \mathrm{L}$ & Secchi, m \\
\hline 3452 & $8 / 31 / 10$ & 25.00 & 14.00 & 0.61 & 2.87 & 5.60 & 0.54 & 5.40 \\
\hline 3454 & $8 / 16 / 11$ & 5.00 & 7.00 & 0.42 & 2.19 & 3.16 & 0.27 & 7.23 \\
\hline 3604 & $8 / 18 / 11$ & 11.00 & 12.00 & 0.47 & 3.00 & 1.88 & 0.46 & 6.28 \\
\hline 3626 & $9 / 1 / 10$ & 5.00 & 20.00 & 1.16 & 11.70 & 7.39 & 1.21 & 4.67 \\
\hline 3672 & $8 / 10 / 11$ & 5.00 & 11.00 & 0.48 & 2.81 & 1.62 & 0.47 & 4.65 \\
\hline 3682 & $8 / 10 / 11$ & 5.00 & 42.00 & 0.46 & 2.49 & 3.36 & 0.60 & 5.43 \\
\hline 3690 & $8 / 31 / 10$ & 5.00 & 10.00 & 0.86 & 4.11 & 5.07 & 0.53 & 5.20 \\
\hline 3780 & $8 / 9 / 11$ & 5.00 & 16.00 & 0.32 & 1.83 & 1.18 & 0.22 & 5.03 \\
\hline 3814 & $8 / 23 / 11$ & 5.00 & 15.00 & 1.17 & 6.71 & 7.99 & 0.99 & 2.25 \\
\hline 3830 & $9 / 8 / 10$ & 5.00 & 31.00 & 0.89 & 7.46 & 4.81 & 0.58 & 5.90 \\
\hline 3884 & $9 / 7 / 10$ & 5.00 & 187.00 & 1.14 & 3.84 & 8.21 & 0.85 & 4.13 \\
\hline 3920 & $8 / 18 / 10$ & 5.00 & 9.00 & 0.79 & 3.82 & 5.05 & 0.52 & 6.74 \\
\hline 4272 & $8 / 8 / 11$ & 15.00 & 16.00 & 0.50 & 2.03 & 2.76 & 0.33 & 5.97 \\
\hline 4316 & $8 / 17 / 10$ & 5.00 & 44.00 & 0.87 & 5.27 & 5.44 & 0.59 & 4.10 \\
\hline 4322 & $8 / 17 / 10$ & 5.00 & 7.00 & 0.51 & 1.99 & 2.46 & 0.35 & 7.14 \\
\hline 4328 & $8 / 17 / 10$ & 5.00 & 2.50 & 0.44 & 1.60 & 3.22 & 0.29 & 10.92 \\
\hline 4330 & $8 / 17 / 10$ & 5.00 & 10.00 & 0.39 & 1.30 & 1.70 & 0.24 & 4.10 \\
\hline 4336 & $8 / 17 / 10$ & 5.00 & 20.00 & 0.69 & 3.07 & 4.51 & 0.50 & 5.74 \\
\hline 4388 & $8 / 15 / 11$ & 31.00 & 36.00 & 0.48 & 1.36 & 2.82 & 0.38 & 4.56 \\
\hline 4452 & $9 / 20 / 12$ & 10.00 & 7.00 & 0.40 & 1.62 & 3.04 & 0.21 & 7.30 \\
\hline 4492 & $8 / 25 / 10$ & 82.00 & 9.00 & 0.45 & 1.88 & 1.72 & 0.37 & 7.39 \\
\hline 4606 & $9 / 19 / 12$ & 5.00 & 2.50 & 0.43 & 1.49 & 3.61 & 0.22 & 11.21 \\
\hline 4608 & $9 / 19 / 12$ & 15.00 & 2.50 & 0.46 & 1.65 & 3.20 & 0.22 & 12.60 \\
\hline 4610 & $9 / 20 / 12$ & 17.00 & 10.00 & 0.44 & 1.48 & 5.38 & 0.24 & 7.42 \\
\hline 4612 & $9 / 20 / 12$ & 21.00 & 19.00 & 0.38 & 1.52 & 4.44 & 0.22 & 6.89 \\
\hline 4614 & $9 / 17 / 12$ & 25.00 & 44.00 & 0.70 & 1.69 & 5.46 & 0.35 & 4.50 \\
\hline
\end{tabular}


Table B4: Continued

\begin{tabular}{|c|c|c|c|c|c|c|c|c|}
\hline Midas & Date & Al, ug/L & Fe, ug/L & Mg, mg/L & $\mathrm{Ca}, \mathrm{mg} / \mathrm{L}$ & $\mathrm{Na}, \mathrm{mg} / \mathrm{L}$ & $\mathrm{K}, \mathrm{mg} / \mathrm{L}$ & Secchi, m \\
\hline 4618 & $9 / 20 / 12$ & 57.00 & 43.00 & 0.85 & 1.97 & 4.10 & 0.29 & 3.63 \\
\hline 4620 & $9 / 17 / 12$ & 18.00 & 42.00 & 0.52 & 1.09 & 5.14 & 0.27 & 4.78 \\
\hline 4622 & $9 / 19 / 12$ & 15.00 & 2.50 & 0.64 & 1.50 & 5.08 & 0.33 & 9.60 \\
\hline 4624 & $9 / 17 / 12$ & 5.00 & 2.50 & 0.70 & 2.32 & 7.96 & 0.45 & 7.91 \\
\hline 4628 & $9 / 17 / 12$ & 109.00 & 144.00 & 0.78 & 1.49 & 5.01 & 0.33 & 4.24 \\
\hline 4630 & $9 / 17 / 12$ & 5.00 & 19.00 & 0.73 & 1.69 & 5.00 & 0.32 & 6.30 \\
\hline 4766 & $8 / 25 / 10$ & 76.00 & 56.00 & 0.38 & 1.71 & 1.37 & 0.30 & 4.70 \\
\hline 4782 & $9 / 8 / 11$ & 62.00 & 44.00 & 0.36 & 1.61 & 1.20 & 0.19 & 2.45 \\
\hline 4788 & $8 / 25 / 10$ & 29.00 & 10.00 & 0.43 & 1.71 & 1.70 & 0.53 & 5.74 \\
\hline 4800 & $9 / 1 / 10$ & 5.00 & 15.00 & 0.72 & 2.19 & 3.98 & 0.59 & 6.70 \\
\hline 4802 & $8 / 10 / 11$ & 5.00 & 48.00 & 0.76 & 2.57 & 3.57 & 0.53 & 3.50 \\
\hline 4806 & $8 / 10 / 11$ & 5.00 & 20.00 & 0.78 & 2.52 & 3.59 & 0.61 & 5.70 \\
\hline 4822 & $8 / 11 / 11$ & 5.00 & 5.00 & 1.31 & 6.30 & 11.00 & 1.06 & 3.16 \\
\hline 4852 & $8 / 11 / 11$ & 5.00 & 13.00 & 0.83 & 3.06 & 4.86 & 0.59 & 7.30 \\
\hline 4857 & $8 / 24 / 10$ & 42.00 & 94.00 & 0.57 & 1.25 & 3.49 & 0.44 & 4.09 \\
\hline 4894 & $8 / 17 / 11$ & 5.00 & 9.00 & 0.60 & 1.88 & 3.48 & 0.55 & 7.48 \\
\hline 4896 & $8 / 31 / 10$ & 19.00 & 30.00 & 0.68 & 2.70 & 2.53 & 0.59 & 6.50 \\
\hline 5024 & $8 / 31 / 11$ & 5.00 & 8.00 & 0.91 & 4.82 & 8.70 & 0.93 & 8.45 \\
\hline 5172 & $8 / 11 / 11$ & 5.00 & 17.00 & 1.41 & 6.14 & 2.98 & 0.67 & 1.05 \\
\hline 5174 & $8 / 11 / 11$ & 5.00 & 43.00 & 0.86 & 5.08 & 3.29 & 0.79 & 3.85 \\
\hline 5198 & $8 / 18 / 10$ & 5.00 & 66.00 & 0.94 & 4.87 & 6.46 & 1.13 & 5.20 \\
\hline 5222 & $9 / 6 / 11$ & 18.00 & 57.00 & 0.81 & 1.82 & 3.82 & 0.52 & 5.85 \\
\hline 5236 & $8 / 19 / 10$ & 5.00 & 5.00 & 1.10 & 7.61 & 4.76 & 0.97 & 2.92 \\
\hline 5240 & $9 / 2 / 10$ & 5.00 & 14.00 & 0.87 & 7.08 & 7.55 & 1.01 & 7.21 \\
\hline 5280 & $8 / 9 / 11$ & 5.00 & 10.00 & 0.73 & 4.30 & 3.30 & 0.58 & 6.00 \\
\hline 5344 & $8 / 22 / 11$ & 5.00 & 19.00 & 0.69 & 2.52 & 3.41 & 0.53 & 3.90 \\
\hline
\end{tabular}


Table B4: Continued

\begin{tabular}{|c|c|c|c|c|c|c|c|c|}
\hline Midas & Date & Al, ug/L & Fe, ug/L & $\mathrm{Mg}, \mathrm{mg} / \mathrm{L}$ & $\mathrm{Ca}, \mathrm{mg} / \mathrm{L}$ & $\mathrm{Na}, \mathrm{mg} / \mathrm{L}$ & $\mathrm{K}, \mathrm{mg} / \mathrm{L}$ & Secchi, m \\
\hline 5348 & $8 / 22 / 11$ & 10.00 & 19.00 & 0.97 & 10.10 & 4.70 & 0.98 & 5.90 \\
\hline 5349 & $8 / 22 / 11$ & 5.00 & 15.00 & 0.56 & 2.86 & 2.87 & 0.40 & 4.45 \\
\hline 5352 & $8 / 19 / 10$ & 5.00 & 11.00 & 0.92 & 8.17 & 4.22 & 0.92 & 3.82 \\
\hline 5386 & $9 / 1 / 10$ & 5.00 & 72.00 & 0.76 & 2.16 & 4.54 & 0.60 & 4.10 \\
\hline 5400 & $8 / 31 / 10$ & 5.00 & 9.00 & 0.81 & 2.50 & 4.29 & 0.82 & 7.20 \\
\hline 5408 & $8 / 26 / 10$ & 14.00 & 31.00 & 1.18 & 6.63 & 4.84 & 1.23 & 1.65 \\
\hline 5416 & $8 / 26 / 10$ & 5.00 & 29.00 & 0.97 & 5.38 & 5.07 & 0.96 & 1.30 \\
\hline 5448 & $8 / 26 / 10$ & 10.00 & 2.50 & 1.27 & 8.75 & 5.87 & 1.23 & 1.65 \\
\hline 5458 & $9 / 2 / 10$ & 5.00 & 14.00 & 1.82 & 8.39 & 4.24 & 0.62 & 5.10 \\
\hline 5490 & $8 / 15 / 11$ & 5.00 & 13.00 & 0.42 & 1.45 & 1.35 & 0.24 & 5.35 \\
\hline 5682 & $9 / 1 / 10$ & 12.00 & 122.00 & 0.93 & 3.20 & 4.30 & 0.76 & 4.46 \\
\hline 5690 & $8 / 17 / 11$ & 5.00 & 46.00 & 1.22 & 3.16 & 4.72 & 0.64 & 3.96 \\
\hline 5710 & $8 / 17 / 11$ & 12.00 & 19.00 & 0.71 & 2.18 & 3.81 & 0.65 & 4.44 \\
\hline 5780 & $8 / 30 / 11$ & 13.00 & 14.00 & 0.56 & 2.77 & 5.33 & 0.49 & 6.40 \\
\hline 5814 & $8 / 18 / 11$ & 5.00 & 7.00 & 0.59 & 4.15 & 3.04 & 0.53 & 7.02 \\
\hline 9685 & $8 / 16 / 11$ & 10.00 & 12.00 & 0.57 & 2.82 & 5.37 & 0.49 & 7.55 \\
\hline 9931 & $8 / 31 / 10$ & 5.00 & 2.50 & 0.80 & 4.24 & 6.28 & 0.89 & 1.93 \\
\hline \multicolumn{9}{|l|}{ LEA } \\
\hline 5780 & $7 / 11 / 13$ & NA & NA & NA & NA & NA & NA & NA \\
\hline 3418 & $6 / 18 / 13$ & NA & NA & NA & NA & NA & NA & 6.28 \\
\hline 5780 & $7 / 11 / 13$ & NA & NA & NA & NA & NA & NA & 6.89 \\
\hline 3130 & 7/18/13 & NA & NA & NA & NA & NA & NA & 6.29 \\
\hline 3382 & $7 / 9 / 13$ & NA & NA & NA & NA & NA & NA & 10.45 \\
\hline 3424 & $7 / 3 / 13$ & NA & NA & NA & NA & NA & NA & 7.19 \\
\hline 3199 & $7 / 12 / 13$ & NA & NA & NA & NA & NA & NA & 7.27 \\
\hline 3134 & $6 / 27 / 13$ & NA & NA & NA & NA & NA & NA & 5.96 \\
\hline
\end{tabular}


Table B4: Continued

\begin{tabular}{|c|c|c|c|c|c|c|c|c|}
\hline Midas & Date & Al, ug/L & $\mathrm{Fe}, \mathrm{ug} / \mathrm{L}$ & $\mathrm{Mg}, \mathrm{mg} / \mathrm{L}$ & $\mathrm{Ca}, \mathrm{mg} / \mathrm{L}$ & $\mathrm{Na}, \mathrm{mg} / \mathrm{L}$ & $\mathbf{K}, \mathbf{m g} / \mathbf{L}$ & Secchi, m \\
\hline 3416 & $6 / 18 / 13$ & NA & NA & NA & NA & NA & NA & 6.06 \\
\hline 9685 & $7 / 11 / 13$ & NA & NA & NA & NA & NA & NA & 7.55 \\
\hline 3420 & $7 / 17 / 13$ & NA & NA & NA & NA & NA & NA & 5.70 \\
\hline 3454 & $7 / 1 / 13$ & NA & NA & NA & NA & NA & NA & NA \\
\hline 5582 & $8 / 26 / 13$ & NA & NA & NA & NA & NA & NA & 4.90 \\
\hline 3134 & $6 / 27 / 13$ & NA & NA & NA & NA & NA & NA & 7.96 \\
\hline 5780 & $7 / 11 / 13$ & NA & NA & NA & NA & NA & NA & 6.51 \\
\hline 5780 & $7 / 11 / 13$ & NA & NA & NA & NA & NA & NA & 7.05 \\
\hline 3132 & $7 / 18 / 13$ & NA & NA & NA & NA & NA & NA & 7.06 \\
\hline 3126 & $7 / 18 / 13$ & NA & NA & NA & NA & NA & NA & 6.30 \\
\hline 3234 & $7 / 1 / 13$ & NA & NA & NA & NA & NA & NA & 5.53 \\
\hline 3374 & $6 / 24 / 13$ & NA & NA & NA & NA & NA & NA & 8.05 \\
\hline 3134 & $6 / 27 / 13$ & NA & NA & NA & NA & NA & NA & NA \\
\hline 3452 & $7 / 31 / 13$ & NA & NA & NA & NA & NA & NA & 5.97 \\
\hline 3454 & $7 / 1 / 13$ & NA & NA & NA & NA & NA & NA & 7.20 \\
\hline 3448 & $8 / 1 / 13$ & NA & NA & NA & NA & NA & NA & 4.83 \\
\hline 3232 & $7 / 16 / 13$ & NA & NA & NA & NA & NA & NA & 6.87 \\
\hline 3456 & $9 / 10 / 13$ & NA & NA & NA & NA & NA & NA & 5.14 \\
\hline 5780 & $7 / 11 / 13$ & NA & NA & NA & NA & NA & NA & NA \\
\hline
\end{tabular}


Table B5: Anions and pH. Results include epilimnetic Alkalinity (Alk), Conductivity (Cond), $\mathrm{Cl}^{-}, \mathrm{NO}_{3}{ }^{-}, \mathrm{SO}_{4}{ }^{3-}, \mathrm{ANC}^{-}, \mathrm{Si}^{-}$and $\mathrm{pH}$ for all lakes in this study. Dates are the same as in Table B4.

\begin{tabular}{|c|c|c|c|c|c|c|c|c|}
\hline Midas & Alk & Cond & $\mathrm{Cl}, \mu \mathrm{eq} / \mathrm{L}$ & $\mathrm{NO}_{3}, \mu \mathrm{eq} / \mathrm{L}$ & $\mathrm{SO}_{4,}, \mu \mathrm{eq} / \mathrm{L}$ & ANC(ueq/L) & $\mathrm{Si}(\mathrm{mg} / \mathrm{L})$ & pH \\
\hline \multicolumn{9}{|l|}{2015} \\
\hline 78 & NA & NA & 36.05 & $<1$ & 43.73 & NA & NA & 7.07 \\
\hline 177 & NA & NA & 97.55 & $<1$ & 29.70 & NA & NA & 6.67 \\
\hline 224 & NA & NA & 14.98 & $<1$ & 54.23 & NA & NA & 7.11 \\
\hline 3444 & NA & NA & 190.35 & $<1$ & 52.80 & NA & NA & 7.17 \\
\hline 3446 & NA & NA & 297.72 & $<1$ & 48.53 & NA & NA & 7.03 \\
\hline 3748 & NA & NA & 332.16 & $<1$ & 62.30 & NA & NA & 7.44 \\
\hline 3750 & NA & NA & 439.57 & $<1$ & 52.89 & NA & NA & 7.58 \\
\hline 3796 & NA & NA & 372.86 & $<1$ & 87.50 & NA & NA & 7.36 \\
\hline 3838 & NA & NA & 386.85 & $<1$ & 52.08 & NA & NA & 7.15 \\
\hline 3916 & NA & NA & 371.28 & $<1$ & 43.18 & NA & NA & 7.03 \\
\hline 4434 & NA & NA & 77.00 & $<1$ & 44.80 & NA & NA & 6.35 \\
\hline 4538 & NA & NA & 36.94 & $<1$ & 39.97 & NA & NA & 6.95 \\
\hline 5172 & NA & NA & 146.29 & $<1$ & 52.89 & NA & NA & 7.32 \\
\hline 5190 & NA & NA & 46.11 & $<1$ & 59.30 & NA & NA & 7.39 \\
\hline 5272 & NA & NA & 171.43 & $<1$ & 38.67 & NA & NA & 7.09 \\
\hline 5274 & NA & NA & 184.39 & $<1$ & 39.01 & NA & NA & 6.99 \\
\hline 5280 & NA & NA & 191.19 & $<1$ & 45.40 & NA & NA & 7.06 \\
\hline 5344 & NA & NA & 205.37 & $<1$ & 35.70 & NA & NA & 7.20 \\
\hline 5348 & NA & NA & 212.90 & 1.39 & 52.29 & NA & NA & 7.65 \\
\hline 5349 & NA & NA & 156.48 & 1.00 & 39.50 & NA & NA & 7.30 \\
\hline 5352 & NA & NA & 211.41 & $<1$ & 52.60 & NA & NA & 7.76 \\
\hline 5400 & NA & NA & 211.52 & 0.03 & 51.88 & NA & NA & 6.94 \\
\hline 5408 & NA & NA & 230.87 & 1.35 & 56.34 & NA & NA & 8.22 \\
\hline
\end{tabular}


Table B5: Continued

\begin{tabular}{|c|c|c|c|c|c|c|c|c|}
\hline Midas & Alk & Cond & $\mathrm{Cl}, \mu \mathrm{eq} / \mathrm{L}$ & $\mathrm{NO}_{3}, \mu \mathrm{eq} / \mathrm{L}$ & $\mathrm{SO}_{4,}, \mu \mathrm{eq} / \mathrm{L}$ & $\operatorname{ANC}($ ueq/L) & $\mathrm{Si}(\mathrm{mg} / \mathrm{L})$ & pH \\
\hline 5448 & NA & NA & 274.58 & 2.12 & 78.40 & NA & NA & 8.94 \\
\hline \multicolumn{9}{|l|}{2016} \\
\hline 4444 & NA & NA & 110.67 & 0.05 & 13.43 & NA & NA & 6.85 \\
\hline 5666 & NA & NA & 208.43 & 0.30 & 15.86 & NA & NA & 6.34 \\
\hline 5814 & NA & NA & 193.97 & 0.25 & 17.69 & NA & NA & 7.35 \\
\hline 5182 & NA & NA & 213.80 & 0.10 & 20.35 & NA & NA & 6.44 \\
\hline 4406 & NA & NA & 126.99 & 0.08 & 8.92 & NA & NA & NA \\
\hline 5330 & NA & NA & 79.45 & 0.03 & 13.85 & NA & NA & 6.44 \\
\hline 5664 & NA & NA & 397.31 & 0.10 & 23.83 & NA & NA & 7.30 \\
\hline 3760 & NA & NA & 134.37 & 0.08 & 12.03 & NA & NA & 7.20 \\
\hline 3762 & NA & NA & 283.83 & 0.06 & 19.38 & NA & NA & 7.37 \\
\hline 5812 & NA & NA & 157.19 & 0.08 & 15.87 & NA & NA & 7.36 \\
\hline 4448 & NA & NA & 139.67 & 0.07 & 12.84 & NA & NA & 6.85 \\
\hline 5186 & NA & NA & 170.62 & 0.23 & 16.54 & NA & NA & 7.15 \\
\hline 3826 & NA & NA & 220.78 & 0.50 & 16.80 & NA & NA & 7.43 \\
\hline 3824 & NA & NA & 201.10 & 0.20 & 16.99 & NA & NA & 7.43 \\
\hline 4446 & NA & NA & 124.28 & 0.17 & 6.55 & NA & NA & 6.29 \\
\hline 3688 & NA & NA & 231.79 & 0.04 & 17.86 & NA & NA & 7.30 \\
\hline 4346 & NA & NA & 137.30 & 0.06 & 12.75 & NA & NA & 6.66 \\
\hline 5184 & NA & NA & 81.49 & 0.13 & 13.17 & NA & NA & 7.14 \\
\hline \multicolumn{9}{|l|}{ DEP } \\
\hline 70 & NA & NA & 172.00 & 0.50 & 63.00 & 334 & 0.95 & 7.32 \\
\hline 80 & NA & NA & 209.00 & 0.50 & 54.00 & 315 & 0.42 & 7.15 \\
\hline 121 & NA & NA & 34.00 & 0.50 & 36.00 & 190 & 0.79 & 7.10 \\
\hline 177 & NA & NA & 122.00 & 0.50 & 41.00 & 110 & 0.59 & 6.87 \\
\hline 243 & NA & NA & 12.00 & 0.50 & 37.00 & 89.2 & 1.59 & 6.78 \\
\hline
\end{tabular}


Table B5: Continued

\begin{tabular}{|c|c|c|c|c|c|c|c|c|}
\hline Midas & Alk & Cond & $\mathrm{Cl}, \mu \mathrm{eq} / \mathrm{L}$ & $\mathrm{NO}_{3}, \mu \mathrm{eq} / \mathrm{L}$ & $\mathrm{SO}_{4,}, \mu \mathrm{eq} / \mathrm{L}$ & $\operatorname{ANC}($ ueq/L) & $\mathrm{Si}(\mathrm{mg} / \mathrm{L})$ & pH \\
\hline 262 & NA & NA & 40.00 & 0.50 & 43.00 & 93.5 & 0.88 & 6.96 \\
\hline 342 & NA & NA & 15.00 & 0.50 & 48.00 & 144 & 2.18 & 6.89 \\
\hline 386 & NA & NA & 85.00 & 0.50 & 47.00 & 139 & 1.14 & NA \\
\hline 410 & NA & NA & 11.00 & 0.50 & 46.00 & 172 & 2.4 & 7.02 \\
\hline 447 & NA & NA & 738.00 & 0.50 & 117.00 & 151 & 1.12 & 6.73 \\
\hline 760 & NA & NA & 33.00 & 0.50 & 69.00 & 503 & 0.74 & 7.61 \\
\hline 954 & NA & NA & 36.00 & 0.50 & 34.00 & 77.3 & 0.79 & 6.62 \\
\hline 1068 & NA & NA & 112.00 & 0.50 & 43.00 & 190 & 0.7 & 7.04 \\
\hline 1070 & NA & NA & 42.00 & 0.50 & 40.00 & 216 & 0.94 & 6.92 \\
\hline 1078 & NA & NA & 39.00 & 0.50 & 31.00 & 72.1 & 0.44 & 6.62 \\
\hline 1088 & NA & NA & 53.00 & 0.50 & 33.00 & 73.3 & 1 & 6.88 \\
\hline 1150 & NA & NA & 28.00 & 0.50 & 48.00 & 107 & 1.18 & 6.88 \\
\hline 1210 & NA & NA & 119.00 & 0.50 & 40.00 & 64.9 & 1.78 & 6.53 \\
\hline 2004 & NA & NA & 14.00 & 0.50 & 46.00 & 94.6 & 1.8 & 6.91 \\
\hline 2020 & NA & NA & 10.00 & 0.50 & 35.00 & 145 & 2.44 & 7.04 \\
\hline 2146 & NA & NA & 52.00 & 0.50 & 52.00 & 119 & 1.19 & 6.88 \\
\hline 2156 & NA & NA & 106.00 & 0.50 & 83.00 & 655 & 1.06 & 7.63 \\
\hline 2242 & NA & NA & 117.00 & 0.50 & 57.00 & 529 & 1.18 & 7.59 \\
\hline 2286 & NA & NA & 258.00 & 0.50 & 39.00 & 589 & 1.23 & 9.06 \\
\hline 2590 & NA & NA & 49.00 & 0.50 & 47.00 & 295 & 0.96 & 7.30 \\
\hline 2608 & NA & NA & 32.00 & 0.50 & 54.00 & 218 & 0.91 & 7.39 \\
\hline 2948 & NA & NA & 11.00 & 0.50 & 46.00 & 227 & 0.87 & 7.02 \\
\hline 3038 & NA & NA & 16.00 & 0.50 & 34.00 & 187 & 0.93 & 7.06 \\
\hline 3376 & NA & NA & 98.00 & 0.50 & 42.00 & 119 & 0.49 & NA \\
\hline 3388 & NA & NA & 241.00 & 0.50 & 52.00 & 162 & 0.58 & 7.06 \\
\hline 3434 & NA & NA & 191.00 & 0.50 & 53.00 & 313 & 1.38 & 7.57 \\
\hline
\end{tabular}


Table B5: Continued

\begin{tabular}{|c|c|c|c|c|c|c|c|c|}
\hline Midas & Alk & Cond & $\mathrm{Cl}, \mu \mathrm{eq} / \mathrm{L}$ & $\mathrm{NO}_{3}, \mu \mathrm{eq} / \mathrm{L}$ & $\mathrm{SO}_{4,}, \mu \mathrm{eq} / \mathrm{L}$ & $\operatorname{ANC}($ ueq/L) & $\mathrm{Si}(\mathrm{mg} / \mathrm{L})$ & pH \\
\hline 3452 & NA & NA & 238.00 & 0.50 & 51.00 & 158 & 1.94 & 7.00 \\
\hline 3454 & NA & NA & 134.00 & 0.50 & 40.00 & 109 & 0.85 & 6.62 \\
\hline 3604 & NA & NA & 61.00 & 0.50 & 53.00 & 155 & 1.63 & NA \\
\hline 3626 & NA & NA & 300.00 & 0.50 & 113.00 & 567 & 3.32 & 7.89 \\
\hline 3672 & NA & NA & 44.00 & 0.50 & 52.00 & 152 & 1.31 & 7.12 \\
\hline 3682 & NA & NA & 127.00 & 0.50 & 57.00 & 136 & 1.37 & 7.00 \\
\hline 3690 & NA & NA & 163.00 & 0.50 & 51.00 & 257 & 2.06 & 7.26 \\
\hline 3780 & NA & NA & 35.00 & 0.50 & 51.00 & 78 & 0.18 & 6.76 \\
\hline 3814 & NA & NA & 359.00 & 0.50 & 65.00 & 368 & 0.91 & 7.82 \\
\hline 3830 & NA & NA & 146.00 & 0.50 & 54.00 & 408 & 0.68 & 7.48 \\
\hline 3884 & NA & NA & 304.00 & 0.50 & 55.00 & 254 & 1.22 & 6.97 \\
\hline 3920 & NA & NA & 218.00 & 0.50 & 66.00 & 193 & 1.62 & 7.07 \\
\hline 4272 & NA & NA & 98.00 & 0.50 & 38.00 & 113 & 1.68 & 6.78 \\
\hline 4316 & NA & NA & 169.00 & 0.50 & 54.00 & 300 & 1.48 & 7.02 \\
\hline 4322 & NA & NA & 65.00 & 0.50 & 52.00 & 110 & 0.81 & 6.84 \\
\hline 4328 & NA & NA & 109.00 & 0.50 & 47.00 & 89.9 & 1.15 & 6.94 \\
\hline 4330 & NA & NA & 46.00 & 0.50 & 45.00 & 76.7 & 0.73 & 6.78 \\
\hline 4336 & NA & NA & 151.00 & 0.50 & 50.00 & 183 & 0.79 & 6.93 \\
\hline 4388 & NA & NA & 110.00 & 0.50 & 40.00 & 72.7 & 1.68 & 6.70 \\
\hline 4452 & NA & NA & 106.00 & 0.50 & 47.00 & 80.8 & 1.47 & 6.79 \\
\hline 4492 & NA & NA & 32.00 & 0.50 & 50.00 & 105 & 2.22 & 6.67 \\
\hline 4606 & NA & NA & 149.00 & 0.50 & 46.00 & 65.2 & 0.55 & 6.74 \\
\hline 4608 & NA & NA & 121.00 & 0.50 & 52.00 & 74.3 & 1.32 & 6.83 \\
\hline 4610 & NA & NA & 224.00 & 0.50 & 50.00 & 56.7 & 0.69 & 6.49 \\
\hline 4612 & NA & NA & 160.00 & 0.50 & 46.00 & 70.9 & 0.7 & 6.52 \\
\hline 4614 & NA & NA & 228.00 & 0.50 & 49.00 & 86.2 & 0.53 & 6.43 \\
\hline
\end{tabular}


Table B5: Continued

\begin{tabular}{|c|c|c|c|c|c|c|c|c|}
\hline Midas & Alk & Cond & $\mathrm{Cl}, \mu \mathrm{eq} / \mathrm{L}$ & $\mathrm{NO}_{3}, \mu \mathrm{eq} / \mathrm{L}$ & $\mathrm{SO}_{4,}, \boldsymbol{\mu e q} / \mathrm{L}$ & $\operatorname{ANC}($ ueq/L) & $\mathrm{Si}(\mathrm{mg} / \mathrm{L})$ & pH \\
\hline 4618 & NA & NA & 149.00 & 0.50 & 45.00 & 119 & 0.75 & 6.57 \\
\hline 4620 & NA & NA & 211.00 & 0.50 & 45.00 & 50.6 & 0.37 & 6.18 \\
\hline 4622 & NA & NA & 210.00 & 0.50 & 57.00 & 68.2 & 0.49 & 6.62 \\
\hline 4624 & NA & NA & 354.00 & 0.50 & 59.00 & 104 & 0.6 & 6.88 \\
\hline 4628 & NA & NA & 207.00 & 0.50 & 40.00 & 71.8 & 1.41 & 6.27 \\
\hline 4630 & NA & NA & 214.00 & 0.50 & 51.00 & 86.5 & 0.69 & 6.68 \\
\hline 4766 & NA & NA & 27.00 & 0.50 & 32.00 & 87.6 & 1.54 & 6.71 \\
\hline 4782 & NA & NA & 27.00 & 0.50 & 36.00 & 69.5 & 0.66 & 6.43 \\
\hline 4788 & NA & NA & 29.00 & 0.50 & 46.00 & 104 & 1.45 & NA \\
\hline 4800 & NA & NA & 142.00 & 0.50 & 50.00 & 122 & 0.57 & 6.95 \\
\hline 4802 & NA & NA & 148.00 & 0.50 & 51.00 & 152 & 0.75 & 6.97 \\
\hline 4806 & NA & NA & 151.00 & 0.50 & 54.00 & 154 & 0.31 & 6.82 \\
\hline 4822 & NA & NA & 490.00 & 0.50 & 96.00 & 323 & 0.16 & 7.45 \\
\hline 4852 & NA & NA & 226.00 & 0.50 & 53.00 & 168 & 0.81 & 6.89 \\
\hline 4857 & NA & NA & 159.00 & 0.50 & 42.00 & 61 & 0.71 & 6.31 \\
\hline 4894 & NA & NA & 177.00 & 0.50 & 39.00 & 89.5 & 0.41 & 6.76 \\
\hline 4896 & NA & NA & 92.00 & 0.50 & 58.00 & 166 & 1.45 & 7.06 \\
\hline 5024 & NA & NA & 430.00 & 0.50 & 54.00 & 218 & 0.76 & 7.06 \\
\hline 5172 & NA & NA & 127.00 & 0.50 & 67.00 & 357 & 0.55 & 8.24 \\
\hline 5174 & NA & NA & 126.00 & 0.50 & 53.00 & 295 & 1.42 & 7.24 \\
\hline 5198 & NA & NA & 304.00 & 0.50 & 59.00 & 289 & 1.14 & 7.23 \\
\hline 5222 & NA & NA & 149.00 & 0.50 & 50.00 & 118 & 1.16 & 6.64 \\
\hline 5236 & NA & NA & 206.00 & 0.50 & 66.00 & 407 & 0.39 & 7.92 \\
\hline 5240 & NA & NA & 270.00 & 0.50 & 68.00 & 377 & 1.1 & 7.62 \\
\hline 5280 & NA & NA & 149.00 & 0.50 & 52.00 & 224 & 0.99 & 7.23 \\
\hline 5344 & NA & NA & 152.00 & 0.50 & 43.00 & 139 & 0.09 & 6.94 \\
\hline
\end{tabular}


Table B5: Continued

\begin{tabular}{|c|c|c|c|c|c|c|c|c|}
\hline Midas & Alk & Cond & $\mathrm{Cl}, \mu \mathrm{eq} / \mathrm{L}$ & $\mathrm{NO}_{3}, \mu \mathrm{eq} / \mathrm{L}$ & $\mathrm{SO}_{4,}, \mu \mathrm{eq} / \mathrm{L}$ & $\operatorname{ANC}($ ueq/L) & $\mathrm{Si}(\mathrm{mg} / \mathrm{L})$ & pH \\
\hline 5348 & NA & NA & 193.00 & 0.50 & 59.00 & 536 & 0.84 & NA \\
\hline 5349 & NA & NA & 128.00 & 0.50 & 49.00 & 135 & 1.4 & 6.95 \\
\hline 5352 & NA & NA & 193.00 & 0.50 & 59.00 & 462 & 0.58 & 8.02 \\
\hline 5386 & NA & NA & 137.00 & 0.50 & 41.00 & 153 & 0.69 & 7.19 \\
\hline 5400 & NA & NA & 182.00 & 0.50 & 54.00 & 153 & 1.19 & 7.18 \\
\hline 5408 & NA & NA & 169.00 & 0.50 & 58.00 & 368 & 1.35 & NA \\
\hline 5416 & NA & NA & 178.00 & 0.50 & 54.00 & 302 & 2.2 & 8.42 \\
\hline 5448 & NA & NA & 216.00 & 0.50 & 95.00 & 436 & 1.09 & 7.78 \\
\hline 5458 & NA & NA & 137.00 & 0.50 & 69.00 & 512 & 1.23 & 7.95 \\
\hline 5490 & NA & NA & 40.00 & 0.50 & 35.00 & 86 & 0.55 & 6.78 \\
\hline 5682 & NA & NA & 127.00 & 0.50 & 47.00 & 218 & 1.03 & 7.26 \\
\hline 5690 & NA & NA & 205.00 & 0.50 & 56.00 & 205 & 0.73 & 6.89 \\
\hline 5710 & NA & NA & 172.00 & 0.50 & 42.00 & 123 & 0.46 & 6.69 \\
\hline 5780 & NA & NA & 216.00 & 0.50 & 49.00 & 140 & 1.1 & 6.90 \\
\hline 5814 & NA & NA & 126.00 & 0.50 & 56.00 & 215 & 0.86 & 7.03 \\
\hline 9685 & NA & NA & 219.00 & 0.50 & 51.00 & 141 & 0.99 & NA \\
\hline 9931 & NA & NA & 237.00 & 0.50 & 53.00 & 219 & 0.74 & 7.35 \\
\hline \multicolumn{9}{|l|}{ LEA } \\
\hline 5780 & NA & $\mathrm{NA}$ & NA & $\mathrm{NA}$ & NA & NA & NA & NA \\
\hline 3418 & 4.3 & 23.97 & NA & NA & NA & NA & NA & 6.67 \\
\hline 5780 & 7.5 & 45.2 & NA & NA & NA & NA & NA & 6.70 \\
\hline 3130 & 5 & 24.02 & NA & NA & NA & NA & NA & 6.71 \\
\hline 3382 & 6.5 & 37.59 & NA & NA & NA & NA & NA & 6.63 \\
\hline 3424 & 5 & 19.8 & NA & NA & NA & NA & NA & 6.90 \\
\hline 3199 & 7.5 & 17.8 & NA & NA & NA & NA & NA & 6.83 \\
\hline 3134 & 6.1 & 25.17 & NA & NA & NA & NA & NA & 6.70 \\
\hline
\end{tabular}


Table B5: Continued

\begin{tabular}{|c|c|c|c|c|c|c|c|c|}
\hline Midas & Alk & Cond & $\mathrm{Cl}, \mu \mathrm{eq} / \mathrm{L}$ & $\mathrm{NO}_{3}, \mu \mathrm{eq} / \mathrm{L}$ & $\mathrm{SO}_{4,}, \mu \mathrm{eq} / \mathrm{L}$ & $\operatorname{ANC}($ ueq/L) & $\mathrm{Si}(\mathrm{mg} / \mathrm{L})$ & $\mathbf{p H}$ \\
\hline 3416 & 6.9 & 32.46 & NA & NA & NA & NA & NA & 6.60 \\
\hline 9685 & 7.9 & 37.5 & NA & NA & NA & NA & NA & 6.65 \\
\hline 3420 & 6.1 & 28.68 & NA & NA & NA & NA & NA & 6.76 \\
\hline 3454 & NA & NA & NA & NA & NA & NA & NA & NA \\
\hline 5582 & 9.1 & 45.71 & NA & NA & NA & NA & NA & 6.73 \\
\hline 3134 & 6.2 & 31.38 & NA & NA & NA & NA & NA & 6.70 \\
\hline 5780 & 8.5 & 46.1 & NA & NA & NA & NA & NA & 6.80 \\
\hline 5780 & 7.3 & 42 & NA & NA & NA & NA & NA & 6.80 \\
\hline 3132 & 4.5 & 23.38 & NA & NA & NA & NA & NA & 6.68 \\
\hline 3126 & 5.4 & 17.84 & NA & NA & NA & NA & NA & 6.64 \\
\hline 3234 & 4.9 & 29.83 & NA & NA & NA & NA & NA & 6.60 \\
\hline 3374 & 6 & 40.2 & NA & NA & NA & NA & NA & 6.85 \\
\hline 3134 & NA & NA & NA & NA & NA & NA & NA & NA \\
\hline 3452 & 8 & 42.9 & NA & NA & NA & NA & NA & 6.90 \\
\hline 3454 & 6 & 30.2 & NA & NA & NA & NA & NA & 6.70 \\
\hline 3448 & 6.5 & 35.3 & NA & NA & NA & NA & NA & 6.70 \\
\hline 3232 & 5.7 & 40.95 & NA & NA & NA & NA & NA & 6.60 \\
\hline 3456 & 4 & 24.01 & NA & NA & NA & NA & NA & 6.55 \\
\hline 5780 & NA & NA & NA & NA & NA & NA & NA & NA \\
\hline
\end{tabular}




\section{APPENDIX C: MODEL PARAMETERS}

Table C1.1: Significant parameters: Watershed and Chemistry. Parameters used for model regression consisting of epilimnetic and hypolimnetic P, chl a; agriculture and watershed characteristics: Ag:WA, AdjAg:LA, Ag:LA, WA:LA, Road:WA ratios; sediment chemistry parameters: $\mathrm{Al}_{\mathrm{NaOH}}: \mathrm{Fe}_{\mathrm{BD}}, \mathrm{Al}_{\mathrm{NaOH}}: \mathrm{P}_{\mathrm{BD}}$, and $\mathrm{P}_{\mathrm{BD}}$.

\begin{tabular}{|c|c|c|c|c|c|c|c|c|c|c|c|c|}
\hline Midas & Date & $\begin{array}{c}\text { Epi. P, } \\
\text { ppb }\end{array}$ & $\begin{array}{c}\text { Hypo. P, } \\
\text { ppb }\end{array}$ & $\begin{array}{c}\text { CHL } \\
\mathbf{a}\end{array}$ & $\begin{array}{c}\text { Ag:WA } \\
\text { ratio }\end{array}$ & $\begin{array}{c}\text { AdjAg:LA } \\
\text { ratio }\end{array}$ & $\begin{array}{c}\text { Ag:LA } \\
\text { ratio }\end{array}$ & WA:LA & Road:WA & $\mathbf{A l}_{\mathrm{NaOH}}: \mathbf{F e}_{\mathrm{BD}}$ & $\mathbf{A l}_{\mathrm{NaOH}}: \mathbf{P}_{\mathrm{BD}}$ & $\mathbf{P}_{\mathrm{BD}}$ \\
\hline \multicolumn{13}{|l|}{2015} \\
\hline 78 & $8 / 25 / 15$ & 4.0 & 3.4 & 1.6 & 0.03 & 0.07 & 0.00 & 9.4 & 0.005 & 0.8 & 97.3 & 2.8 \\
\hline 177 & $8 / 14 / 15$ & 5.2 & 4.6 & 3.3 & 1.59 & 1.14 & 0.06 & 3.9 & 0.005 & 0.5 & 41.0 & 3.0 \\
\hline 224 & $8 / 25 / 15$ & 1.9 & 2.6 & $<1$ & 0.00 & 0.00 & 0.00 & 4.7 & 0.009 & 0.7 & 39.0 & 5.8 \\
\hline 3444 & $8 / 12 / 15$ & 3.5 & 4.9 & 2.1 & 5.27 & 13.10 & 0.32 & 7.2 & 0.010 & 1.0 & 65.8 & 5.7 \\
\hline 3446 & $8 / 20 / 15$ & 4.2 & 9.1 & 2.7 & 3.31 & 4.17 & 0.12 & 3.6 & 0.011 & 4.5 & 71.9 & 2.8 \\
\hline 3748 & $8 / 27 / 15$ & 6.1 & 20.7 & 2.3 & 9.24 & 16.20 & 0.36 & 5.5 & 0.010 & 1.1 & 7.8 & 15.4 \\
\hline 3750 & $8 / 20 / 15$ & 5.1 & 9.2 & 3.2 & 10.69 & 5.60 & 1.53 & 14.6 & 0.011 & 1.5 & 66.8 & 3.2 \\
\hline 3796 & $8 / 12 / 15$ & 19.2 & NA & 22.1 & 7.80 & 31.34 & 1.45 & 10.3 & 0.010 & 0.8 & 13.5 & 11.8 \\
\hline 3838 & $8 / 24 / 25$ & 5.5 & 9.1 & 2.4 & 6.48 & 4.76 & 0.89 & 29.7 & 0.014 & 0.3 & 6.8 & 42.3 \\
\hline 3916 & $8 / 24 / 25$ & 4.0 & 13.2 & 2.4 & 1.64 & 1.76 & 0.06 & 5.2 & 0.014 & 0.8 & 21.4 & 7.4 \\
\hline 4434 & $8 / 14 / 15$ & 2.6 & 2.4 & 1.4 & 0.02 & 0.02 & 0.00 & 4.5 & 0.003 & 0.2 & 80.0 & 1.8 \\
\hline 4538 & $8 / 26 / 15$ & 4.4 & 5.5 & 1.6 & 0.08 & 0.00 & 0.00 & 4.5 & 0.008 & 5.2 & 214.8 & 1.9 \\
\hline 5172 & $8 / 11 / 15$ & 12.6 & 10.6 & 25.3 & 14.03 & 6.57 & 3.40 & 31.5 & 0.008 & 1.3 & 10.7 & 13.1 \\
\hline 5190 & $8 / 18 / 15$ & 3.3 & 4.3 & 1.2 & 0.96 & 0.86 & 0.05 & 5.1 & 0.008 & 2.7 & 122.7 & 3.0 \\
\hline 5272 & $8 / 19 / 15$ & 5.3 & 53.3 & 4.6 & 2.56 & 1.27 & 0.15 & 59.8 & 0.007 & 1.5 & 32.3 & 9.7 \\
\hline 5274 & $8 / 19 / 15$ & 6.8 & 8.1 & 4.3 & 3.61 & 3.07 & 0.12 & 6.5 & 0.006 & 1.3 & 28.1 & 7.7 \\
\hline 5280 & $8 / 13 / 15$ & 7.5 & 19.6 & 3.5 & 8.60 & 7.31 & 0.72 & 39.1 & 0.008 & 0.3 & 2.8 & 82.5 \\
\hline 5344 & $8 / 13 / 15$ & 19.0 & 15.3 & 5.2 & 7.99 & 6.63 & 0.43 & 8.4 & 0.009 & 1.4 & 40.9 & 2.8 \\
\hline 5348 & $8 / 11 / 15$ & 9.3 & NA & 2.9 & 2.63 & 3.24 & 0.16 & 6.0 & 0.012 & 2.5 & 95.6 & 5.4 \\
\hline
\end{tabular}


Table C1.1: Continued

\begin{tabular}{|c|c|c|c|c|c|c|c|c|c|c|c|c|}
\hline Midas & & $\begin{array}{c}\text { Epi. } P, \\
\text { ppb }\end{array}$ & $\begin{array}{c}\text { Hypo. P, } \\
\text { ppb }\end{array}$ & $\begin{array}{c}\text { CHL } \\
\mathbf{a} \\
\end{array}$ & $\begin{array}{c}\text { Ag:WA } \\
\text { ratio }\end{array}$ & $\begin{array}{c}\text { AdjAg:LA } \\
\text { ratio }\end{array}$ & $\begin{array}{c}\text { Ag:LA } \\
\text { ratio }\end{array}$ & WA:LA & Road:WA & $\mathrm{Al}_{\mathrm{NaOH}}: \mathrm{Fe}_{\mathrm{BD}}$ & $\mathbf{A l}_{\mathrm{NaOH}}: \mathbf{P}_{\mathrm{BD}}$ & $\mathbf{P}_{\text {BD }}$ \\
\hline 5349 & $8 / 18 / 15$ & 12.6 & NA & 3.6 & 1.25 & 0.97 & 0.03 & 2.8 & 0.012 & 1.2 & 27.0 & 6.2 \\
\hline 5352 & $8 / 13 / 15$ & 10.7 & 23.7 & 5.0 & 5.68 & 6.74 & 0.22 & 10.8 & 0.017 & 1.3 & 13.6 & 25.2 \\
\hline 5400 & $8 / 28 / 15$ & 7.5 & 14.2 & 5.4 & 8.58 & 22.36 & 0.52 & 18.7 & 0.010 & 1.5 & 62.1 & 5.0 \\
\hline 5408 & $8 / 10 / 15$ & 21.0 & 280.0 & 6.4 & 11.69 & 25.55 & 0.62 & 5.5 & 0.010 & 1.3 & 10.4 & 46.7 \\
\hline 5448 & $8 / 10 / 15$ & 13.9 & 33.3 & 17.1 & 10.51 & 27.13 & 0.55 & 12.0 & 0.008 & 0.8 & 2.4 & 53.1 \\
\hline \multicolumn{13}{|l|}{2016} \\
\hline 3688 & $8 / 26 / 16$ & 6.4 & 11.5 & 3.5 & NA & NA & NA & NA & NA & 3.3 & 34.2 & 10.6 \\
\hline 3760 & $8 / 23 / 16$ & 8.5 & 11.5 & 1.2 & NA & NA & NA & NA & NA & 3.2 & 55.8 & 5.5 \\
\hline 3762 & $8 / 26 / 16$ & 5.3 & 10.3 & 1.1 & NA & NA & NA & NA & NA & 2.9 & 54.9 & 7.8 \\
\hline 3824 & $8 / 11 / 16$ & 18.6 & NA & 0.9 & NA & NA & NA & NA & NA & 1.8 & 45.2 & 11.5 \\
\hline 3826 & $8 / 26 / 16$ & 8.0 & NA & 6.9 & NA & NA & NA & NA & NA & 2.8 & 25.4 & 13.7 \\
\hline 4346 & $9 / 1 / 16$ & 17.2 & NA & 1.9 & NA & NA & NA & NA & NA & 6.8 & 95.9 & 4.5 \\
\hline 4406 & $9 / 2 / 16$ & 20.0 & 310.0 & 5.8 & NA & NA & NA & NA & NA & 2.1 & 57.7 & 4.9 \\
\hline 4444 & $8 / 12 / 16$ & 12.0 & NA & 3.6 & NA & NA & NA & NA & NA & 3.6 & 76.3 & 4.9 \\
\hline 4446 & $9 / 1 / 16$ & 14.5 & NA & 1.9 & NA & NA & NA & NA & NA & 4.0 & 69.7 & 6.2 \\
\hline 4448 & $9 / 1 / 16$ & 4.8 & NS & 3.8 & NA & NA & NA & NA & NA & 1.1 & 15.7 & 31.9 \\
\hline 5182 & $8 / 10 / 16$ & 23.1 & 9.3 & 0.9 & NA & NA & NA & NA & NA & 12.4 & 188.8 & 1.4 \\
\hline 5184 & $8 / 11 / 16$ & 8.8 & 16.1 & 0.0 & NA & NA & NA & NA & NA & 5.0 & 108.8 & 2.8 \\
\hline 5186 & $8 / 11 / 16$ & 5.0 & 13.1 & 2.4 & NA & NA & NA & NA & NA & 1.6 & 31.3 & 5.2 \\
\hline 5330 & $8 / 10 / 16$ & 23.1 & NA & 0.9 & NA & NA & NA & NA & NA & 1.5 & 42.9 & 4.3 \\
\hline 5664 & $8 / 26 / 16$ & 9.3 & NA & 1.9 & NA & NA & NA & NA & NA & 1.8 & 26.9 & 7.2 \\
\hline 5666 & $8 / 8 / 16$ & 9.0 & 20.3 & 1.8 & NA & NA & NA & NA & NA & 3.7 & 33.0 & 7.7 \\
\hline 5812 & $8 / 23 / 16$ & 6.5 & 11.8 & 1.0 & NA & NA & NA & NA & NA & 4.5 & 126.3 & 2.8 \\
\hline 5814 & $8 / 8 / 16$ & 5.7 & 11.1 & 0.0 & NA & NA & NA & NA & NA & 6.8 & 22.1 & 9.4 \\
\hline
\end{tabular}


Table C1.1: Continued

\begin{tabular}{|c|c|c|c|c|c|c|c|c|c|c|c|c|}
\hline Midas & & $\begin{array}{c}\text { Epi. P, } \\
\text { ppb }\end{array}$ & $\begin{array}{c}\text { Hypo. P, } \\
\text { ppb }\end{array}$ & $\begin{array}{c}\text { CHL } \\
\mathbf{a}\end{array}$ & $\begin{array}{c}\text { Ag:WA } \\
\text { ratio }\end{array}$ & $\begin{array}{c}\text { AdjAg:LA } \\
\text { ratio }\end{array}$ & $\begin{array}{c}\text { Ag:LA } \\
\text { ratio }\end{array}$ & WA:LA & Road:WA & $\mathrm{Al}_{\mathrm{NaOH}}: \mathbf{F e}_{\mathrm{BD}}$ & $\mathbf{A} \mathbf{l}_{\mathrm{NaOH}}: \mathbf{P}_{\mathrm{BD}}$ & $\mathbf{P}_{\text {BD }}$ \\
\hline 70 & $8 / 9 / 11$ & 9.0 & NA & 6.2 & 12.69 & 14.74 & 1.08 & 8.2 & 0.010 & 0.8 & 51.0 & 6.1 \\
\hline 80 & $8 / 24 / 11$ & 13.0 & NA & 3.1 & NA & NA & NA & NA & 0.007 & 1.2 & 54.0 & 4.1 \\
\hline 121 & $8 / 24 / 11$ & 6.0 & 14.0 & 4.4 & NA & NA & NA & 101.5 & & 2.6 & 151.1 & 2.0 \\
\hline 177 & $9 / 23 / 10$ & 6.0 & NA & 2.1 & 1.59 & 1.14 & 0.06 & 3.9 & 0.005 & 0.5 & 41.0 & 6.6 \\
\hline 243 & $9 / 1 / 11$ & 4.0 & NA & 2.1 & 0.00 & 0.00 & 0.00 & 8.6 & 0.002 & 1.5 & 9077.1 & 0.0 \\
\hline 262 & $8 / 30 / 10$ & 9.0 & NA & 2.4 & 0.00 & 0.00 & 0.00 & 20.9 & 0.008 & 3.2 & 223.5 & 3.0 \\
\hline 342 & $9 / 1 / 11$ & 3.0 & NA & 1.7 & 0.00 & 0.00 & 0.00 & 15.3 & 0.007 & 1.4 & 67.5 & 5.1 \\
\hline 386 & $8 / 23 / 11$ & 15.0 & 42.0 & 4.9 & 0.00 & 0.00 & 0.00 & 11.0 & 0.018 & 1.9 & 150.1 & 2.2 \\
\hline 410 & 9/1/11 & 10.0 & NA & 4.6 & 0.00 & 0.00 & 0.00 & NA & 0.000 & 0.5 & 54.3 & 3.8 \\
\hline 447 & $9 / 23 / 12$ & 7.0 & NA & 1.7 & 0.00 & 0.00 & 0.00 & 443.6 & 0.000 & 2.6 & 70.9 & 1.7 \\
\hline 760 & $8 / 30 / 10$ & 10.0 & NA & 4.1 & 4.94 & 6.75 & 0.43 & 9.6 & 0.012 & 1.3 & 14.8 & 8.0 \\
\hline 954 & $8 / 23 / 10$ & 4.0 & NA & 1.9 & 0.15 & 0.00 & 0.01 & 9.3 & 0.003 & 1.3 & 224.0 & 1.6 \\
\hline 1068 & $8 / 24 / 11$ & 6.0 & NA & 1.9 & 4.00 & 2.12 & 0.18 & 8.8 & 0.012 & 1.6 & 92.5 & 1.3 \\
\hline 1070 & $8 / 24 / 11$ & 5.0 & NA & 2.4 & NA & NA & NA & 5.6 & 0.003 & 0.9 & 46.7 & 8.2 \\
\hline 1078 & $8 / 22 / 11$ & 9.0 & NA & 3.3 & 0.04 & 0.00 & 0.00 & 12.1 & 0.000 & 1.0 & 234.3 & 0.9 \\
\hline 1088 & $8 / 22 / 11$ & 8.0 & NA & 2.1 & 0.11 & 0.00 & 0.02 & 15.9 & 0.002 & 1.8 & 7835.9 & 0.0 \\
\hline 1150 & $9 / 23 / 10$ & 4.0 & NA & 1.9 & 0.00 & 0.00 & 0.00 & 10.1 & 0.001 & 0.5 & 63.3 & 2.9 \\
\hline 1210 & $8 / 25 / 10$ & 6.0 & 10.0 & 1.8 & 0.05 & 0.00 & 0.01 & 11.1 & 0.002 & 1.2 & 85.4 & 6.5 \\
\hline 2004 & $8 / 23 / 10$ & 5.0 & NA & 1.4 & 0.00 & 0.00 & 0.00 & 5.0 & 0.006 & 4.3 & 655.2 & 1.4 \\
\hline 2020 & $8 / 15 / 11$ & 5.0 & NA & 1.8 & 0.00 & 0.00 & 0.00 & 138.1 & 0.003 & 0.5 & 52.8 & 3.2 \\
\hline 2146 & $8 / 17 / 11$ & 6.0 & NA & 2.3 & 0.53 & 0.82 & 0.02 & 25.8 & 0.007 & 1.4 & 99.4 & 1.8 \\
\hline 2156 & $8 / 24 / 11$ & 15.0 & NA & 7.2 & 19.64 & 15.95 & 3.62 & 19.8 & 0.009 & 1.2 & 19.5 & 5.8 \\
\hline 2242 & $8 / 17 / 11$ & 5.0 & NA & 1.9 & 1.91 & 7.21 & 0.15 & 7.5 & 0.012 & 3.4 & 22.9 & 6.6 \\
\hline 2286 & $9 / 2 / 10$ & 33.0 & NA & 34.0 & 7.47 & 23.22 & 5.09 & 134.9 & 0.007 & 0.9 & 10.8 & 13.8 \\
\hline 2590 & $8 / 30 / 10$ & 7.0 & 12.0 & 3.0 & 4.26 & 5.96 & 0.77 & 36.4 & 0.007 & 1.5 & 53.9 & 5.3 \\
\hline 2608 & $8 / 30 / 10$ & 6.0 & 17.0 & 5.0 & 1.65 & 0.10 & 0.21 & 12.9 & 0.006 & 2.3 & 73.7 & 8.9 \\
\hline
\end{tabular}


Table C1.1: Continued

\begin{tabular}{|c|c|c|c|c|c|c|c|c|c|c|c|c|}
\hline Midas & & $\begin{array}{c}\text { Epi. P, } \\
\text { ppb }\end{array}$ & $\begin{array}{c}\text { Hypo. P, } \\
\text { ppb }\end{array}$ & $\begin{array}{c}\mathrm{CHL} \\
\mathbf{a}\end{array}$ & $\begin{array}{c}\text { Ag:WA } \\
\text { ratio }\end{array}$ & $\begin{array}{c}\text { AdjAg:LA } \\
\text { ratio }\end{array}$ & $\begin{array}{c}\text { Ag:LA } \\
\text { ratio }\end{array}$ & WA:LA & Road:WA & $A \mathbf{l}_{\mathrm{NaOH}}: \mathbf{F e}_{\mathrm{BD}}$ & $\mathbf{A l}_{\mathrm{NaOH}}: \mathbf{P}_{\mathrm{BD}}$ & $\mathbf{P}_{\mathrm{BD}}$ \\
\hline 2948 & $8 / 30 / 10$ & 5.0 & NA & 2.3 & 0.00 & 0.00 & 0.00 & 10.8 & 0.000 & 0.6 & 46.0 & 5.3 \\
\hline 3038 & $8 / 24 / 11$ & 7.0 & NA & 3.6 & 2.14 & 1.99 & 0.32 & 20.7 & 0.003 & 1.8 & 436.6 & 0.4 \\
\hline 3376 & $8 / 25 / 11$ & 14.0 & NA & 7.7 & 0.93 & 0.29 & 0.14 & 15.0 & 0.010 & 5.2 & 43.6 & 4.6 \\
\hline 3388 & $9 / 7 / 10$ & 6.0 & NA & 2.6 & 3.61 & 14.77 & 0.19 & 7.8 & 0.016 & 1.8 & 66.5 & 3.4 \\
\hline 3434 & $9 / 1 / 10$ & 9.0 & 14.0 & 2.5 & 9.41 & 18.29 & 1.00 & 15.0 & 0.015 & 2.6 & 59.5 & 8.8 \\
\hline 3452 & $8 / 31 / 10$ & 6.0 & NA & 2.2 & 6.58 & 17.48 & 0.90 & 14.1 & 0.010 & 1.9 & 192.4 & 2.9 \\
\hline 3454 & $8 / 16 / 11$ & 6.0 & 14.0 & 2.9 & 3.41 & 8.50 & 0.17 & 9.6 & 0.011 & 3.8 & 10248.3 & 0.0 \\
\hline 3604 & $8 / 18 / 11$ & 5.0 & 9.0 & 4.2 & 3.67 & 25.16 & 0.57 & 16.0 & 0.007 & 2.2 & 92.3 & 2.9 \\
\hline 3626 & $9 / 1 / 10$ & 8.0 & 16.0 & 2.1 & 2.26 & 0.00 & 0.16 & 10.4 & 0.026 & 1.7 & 27.2 & 13.1 \\
\hline 3672 & $8 / 10 / 11$ & 7.0 & 9.0 & 8.0 & 0.61 & 10.85 & 0.14 & 22.9 & 0.003 & 1.3 & 172.7 & 1.9 \\
\hline 3682 & $8 / 10 / 11$ & 6.0 & NA & 3.6 & 2.37 & 17.36 & 0.72 & 31.1 & 0.005 & 1.0 & 320.9 & 1.3 \\
\hline 3690 & $8 / 31 / 10$ & 7.0 & 13.0 & 3.4 & 2.63 & 0.48 & 0.25 & 9.7 & 0.010 & 3.0 & 33.8 & 10.8 \\
\hline 3780 & $8 / 9 / 11$ & 8.0 & $\mathrm{NA}$ & 4.5 & 1.78 & 4.89 & 0.08 & 4.5 & 0.012 & 4.5 & 127.9 & 2.7 \\
\hline 3814 & $8 / 23 / 11$ & 16.0 & 82.0 & 32.0 & 13.07 & 47.42 & 0.70 & 5.5 & 0.016 & 1.4 & 20.1 & 11.4 \\
\hline 3830 & $9 / 8 / 10$ & 7.0 & 42.0 & 3.7 & 5.90 & 9.29 & 1.28 & 54.1 & 0.008 & 1.5 & 26.2 & 14.3 \\
\hline 3884 & 9/7/10 & 13.0 & NA & 4.4 & 9.99 & 44.05 & 0.45 & 5.0 & 0.015 & 0.7 & 13.9 & 12.8 \\
\hline 3920 & $8 / 18 / 10$ & 10.0 & 11.0 & 1.5 & NA & NA & 0.48 & 6.0 & 0.012 & 2.2 & 56.5 & 6.3 \\
\hline 4272 & $8 / 8 / 11$ & 5.0 & 10.0 & 2.1 & 0.63 & 2.71 & 0.03 & 16.7 & 0.007 & 1.7 & 200.7 & 2.3 \\
\hline 4316 & $8 / 17 / 10$ & 11.0 & 30.0 & 4.2 & 5.42 & 3.45 & 3.68 & 90.1 & 0.007 & 1.3 & 64.2 & 4.5 \\
\hline 4322 & $8 / 17 / 10$ & 5.0 & 12.0 & 3.4 & 0.55 & 2.16 & 0.05 & 9.3 & 0.009 & 3.0 & 153.3 & 3.5 \\
\hline 4328 & $8 / 17 / 10$ & 3.0 & NA & 1.5 & 1.87 & 2.21 & 0.12 & 6.6 & 0.007 & 1.0 & 213.0 & 2.5 \\
\hline 4330 & $8 / 17 / 10$ & 10.0 & NA & 2.9 & 0.90 & 3.80 & 0.08 & 9.0 & 0.007 & 3.3 & 137.3 & 2.9 \\
\hline 4336 & $8 / 17 / 10$ & 9.0 & NA & 3.2 & 2.40 & 6.45 & 0.29 & 64.7 & 0.008 & 1.6 & 88.8 & 3.0 \\
\hline 4388 & $8 / 15 / 11$ & 7.0 & 12.0 & 4.5 & 0.79 & 6.09 & 0.08 & 9.2 & 0.008 & 3.1 & 4798.8 & 0.0 \\
\hline 4452 & $9 / 20 / 12$ & 3.0 & NA & 2.3 & 0.00 & 0.00 & 0.00 & 15.3 & 0.016 & 2.3 & 15711.8 & 0.0 \\
\hline 4492 & $8 / 25 / 10$ & 5.0 & 7.0 & 2.0 & 0.00 & 0.00 & NA & 10.8 & 0.007 & 3.2 & 175.8 & 1.8 \\
\hline
\end{tabular}


Table C1.1: Continued

\begin{tabular}{|c|c|c|c|c|c|c|c|c|c|c|c|c|}
\hline Midas & & $\begin{array}{c}\text { Epi. P, } \\
\text { ppb }\end{array}$ & $\begin{array}{c}\text { Hypo. P, } \\
\text { ppb }\end{array}$ & $\begin{array}{c}\mathrm{CHL} \\
\mathbf{a}\end{array}$ & $\begin{array}{c}\text { Ag:WA } \\
\text { ratio }\end{array}$ & $\begin{array}{c}\text { AdjAg:LA } \\
\text { ratio }\end{array}$ & $\begin{array}{c}\text { Ag:LA } \\
\text { ratio }\end{array}$ & WA:LA & Road:WA & $A \mathbf{l}_{\mathrm{NaOH}}: \mathrm{Fe}_{\mathrm{BD}}$ & $\mathbf{A l}_{\mathrm{NaOH}}: \mathbf{P}_{\mathrm{BD}}$ & $\mathbf{P}_{\text {BD }}$ \\
\hline 4606 & $9 / 19 / 12$ & 2.0 & NA & 0.9 & 0.00 & 0.00 & 0.00 & 5.3 & 0.012 & 2.4 & 10613.6 & 0.0 \\
\hline 4608 & $9 / 19 / 12$ & 2.0 & NA & 0.9 & 0.00 & 0.00 & 0.00 & 6.7 & 0.004 & 0.5 & 9010.6 & 0.0 \\
\hline 4610 & $9 / 20 / 12$ & 4.0 & 11.0 & 2.4 & 0.00 & 0.00 & 0.00 & 33.0 & 0.028 & 4.9 & 16090.4 & 0.0 \\
\hline 4612 & $9 / 20 / 12$ & 4.0 & 6.0 & 2.3 & 0.00 & 0.00 & 0.00 & 21.8 & 0.008 & 6.0 & 16471.0 & 0.0 \\
\hline 4614 & $9 / 17 / 12$ & 5.0 & 24.0 & 2.0 & 0.00 & 0.00 & NA & 62.7 & 0.016 & 3.8 & 86.1 & 2.9 \\
\hline 4618 & $9 / 20 / 12$ & 12.0 & NA & 3.4 & 0.00 & 0.00 & 0.00 & 12.4 & 0.014 & 3.5 & 52.4 & 3.4 \\
\hline 4620 & $9 / 17 / 12$ & 7.0 & NA & 2.8 & 0.00 & 0.00 & 0.00 & 6.6 & 0.006 & 3.5 & 84.1 & 2.8 \\
\hline 4622 & $9 / 19 / 12$ & 2.0 & NA & 1.9 & 0.00 & 0.00 & 0.00 & 0.5 & 0.010 & 0.3 & 722.9 & 0.4 \\
\hline 4624 & $9 / 17 / 12$ & 4.0 & 6.0 & 2.0 & 0.00 & 0.00 & 0.00 & 6.5 & 0.019 & 2.9 & 7508.2 & 0.0 \\
\hline 4628 & $9 / 17 / 12$ & 8.0 & NA & 2.0 & 0.00 & 0.00 & 0.00 & 20.2 & 0.044 & 4.9 & 9455.8 & 0.0 \\
\hline 4630 & $9 / 17 / 12$ & 3.0 & 8.0 & 2.1 & 0.00 & 0.00 & 0.00 & 12.5 & 0.010 & 2.3 & 11759.2 & 0.0 \\
\hline 4766 & $8 / 25 / 10$ & 8.0 & NA & 2.8 & 0.18 & 0.00 & 0.01 & 9.4 & 0.003 & 1.1 & 136.8 & 3.2 \\
\hline 4782 & 9/8/11 & 8.0 & NA & 3.9 & 0.08 & 0.00 & 0.00 & 6.9 & 0.004 & 5.0 & 8187.6 & 0.0 \\
\hline 4788 & $8 / 25 / 10$ & 6.0 & NA & 2.5 & 0.00 & 0.00 & 0.00 & 4.7 & 0.004 & 3.7 & 210.6 & 0.8 \\
\hline 4800 & $9 / 1 / 10$ & 6.0 & 13.0 & 2.3 & 10.19 & 26.29 & 0.59 & 35.7 & 0.025 & 1.9 & 75.5 & 7.6 \\
\hline 4802 & $8 / 10 / 11$ & 11.0 & NA & 4.7 & 0.00 & 0.00 & NA & 21.7 & 0.010 & 3.4 & 4457.6 & 0.0 \\
\hline 4806 & $8 / 10 / 11$ & 17.0 & NA & 6.8 & 9.70 & 62.43 & 0.79 & 7.9 & 0.014 & 2.1 & 113.4 & 2.4 \\
\hline 4822 & $8 / 11 / 11$ & 13.0 & 57.0 & 14.0 & 9.89 & 33.02 & 0.59 & 7.7 & 0.021 & 0.9 & 11.8 & 16.3 \\
\hline 4852 & $8 / 11 / 11$ & 6.0 & NA & 6.2 & 7.18 & 20.97 & 0.62 & 15.1 & 0.016 & 0.4 & 8.4 & 11.3 \\
\hline 4857 & $8 / 24 / 10$ & 9.0 & 15.0 & 4.2 & 1.65 & 11.90 & 0.15 & 8.2 & 0.009 & 2.5 & 100.3 & 2.9 \\
\hline 4894 & $8 / 17 / 11$ & 6.0 & NA & 2.3 & 2.39 & 5.80 & 0.09 & 5.1 & 0.019 & 2.0 & 219.1 & 1.6 \\
\hline 4896 & $8 / 31 / 10$ & 6.0 & NA & 2.0 & 2.90 & 5.66 & 0.44 & 24.4 & 0.010 & 0.6 & 39.5 & 10.1 \\
\hline 5024 & $8 / 31 / 11$ & 5.0 & 22.0 & 2.1 & 3.14 & 12.60 & 0.20 & 8.3 & 0.444 & 1.5 & 55.3 & 4.4 \\
\hline 5172 & $8 / 11 / 11$ & 18.0 & 34.0 & 61.0 & 14.03 & 6.57 & 3.40 & 31.5 & 0.008 & 1.3 & 10.7 & 15.1 \\
\hline 5174 & $8 / 11 / 11$ & 16.0 & NA & 5.5 & 7.38 & 9.58 & 0.71 & 12.3 & 0.013 & 1.9 & 67.1 & 2.2 \\
\hline 5198 & $8 / 18 / 10$ & 12.0 & NA & 3.5 & 17.74 & 4.75 & 2.75 & 14.0 & 0.015 & 1.1 & 34.3 & 11.4 \\
\hline
\end{tabular}


Table C1.1: Continued

\begin{tabular}{|c|c|c|c|c|c|c|c|c|c|c|c|c|}
\hline Midas & & $\begin{array}{c}\text { Epi. P, } \\
\text { ppb }\end{array}$ & $\begin{array}{c}\text { Hypo. P, } \\
\text { ppb }\end{array}$ & $\begin{array}{c}\text { CHL } \\
\mathbf{a} \\
\end{array}$ & $\begin{array}{c}\text { Ag:WA } \\
\text { ratio }\end{array}$ & $\begin{array}{c}\text { AdjAg:LA } \\
\text { ratio }\end{array}$ & $\begin{array}{c}\text { Ag:LA } \\
\text { ratio }\end{array}$ & WA:LA & Road:WA & $A \mathbf{l}_{\mathrm{NaOH}}: \mathrm{Fe}_{\mathrm{BD}}$ & $\mathbf{A l}_{\mathrm{NaOH}}: \mathbf{P}_{\mathrm{BD}}$ & $\mathbf{P}_{\mathrm{BD}}$ \\
\hline 5222 & $9 / 6 / 11$ & 10.0 & 22.0 & 3.8 & 3.33 & 40.36 & 0.94 & 30.7 & 0.009 & 1.8 & 147.0 & 2.8 \\
\hline 5236 & $8 / 19 / 10$ & 12.0 & 24.5 & 11.0 & 15.35 & 19.12 & 0.71 & 15.8 & 0.010 & 0.5 & 3.6 & 62.6 \\
\hline 5240 & $9 / 2 / 10$ & 8.0 & 17.0 & 2.7 & 5.75 & 12.73 & 0.23 & 21.3 & 0.015 & 1.4 & 32.4 & 10.5 \\
\hline 5280 & $8 / 9 / 11$ & 9.0 & NA & 4.0 & 8.60 & 7.31 & 0.72 & 39.1 & 0.008 & 0.3 & 2.8 & 77.1 \\
\hline 5344 & $8 / 22 / 11$ & 18.0 & NA & 4.5 & 7.99 & 6.63 & 0.43 & 8.4 & 0.009 & 1.4 & 40.9 & 4.7 \\
\hline 5348 & $8 / 22 / 11$ & 9.0 & NA & 3.2 & 2.63 & 3.24 & 0.16 & NA & 0.012 & 2.5 & 95.4 & 1.8 \\
\hline 5349 & $8 / 22 / 11$ & 15.0 & NA & 11.0 & 1.25 & 0.97 & 0.03 & 2.8 & 0.012 & 1.2 & 27.0 & 7.1 \\
\hline 5352 & $8 / 19 / 10$ & 11.0 & 187.0 & 6.9 & 5.68 & 6.74 & 0.22 & NA & 0.017 & 1.3 & 13.6 & 12.2 \\
\hline 5386 & $9 / 1 / 10$ & 12.0 & NA & 3.4 & 8.21 & 19.77 & 1.57 & 31.9 & 0.009 & 1.9 & 95.5 & 5.1 \\
\hline 5400 & $8 / 31 / 10$ & 7.0 & NA & 4.5 & 8.58 & 22.36 & 0.52 & 18.7 & 0.010 & 1.5 & 62.2 & 5.5 \\
\hline 5408 & $8 / 26 / 10$ & 32.0 & 300.0 & 19.0 & 11.69 & 25.55 & 0.62 & 5.5 & 0.010 & 1.3 & 10.4 & 16.7 \\
\hline 5416 & $8 / 26 / 10$ & 35.0 & 55.0 & 53.0 & 7.82 & 2.16 & 0.49 & 14.9 & 0.011 & 0.7 & 3.8 & 31.4 \\
\hline 5448 & $8 / 26 / 10$ & 18.0 & 38.5 & 28.0 & 10.51 & 27.13 & 0.55 & 12.0 & 0.007 & 0.8 & 2.4 & 46.7 \\
\hline 5458 & $9 / 2 / 10$ & 12.0 & NA & 5.5 & 4.07 & 15.71 & 0.70 & 20.8 & 0.008 & 1.1 & 16.1 & 13.2 \\
\hline 5490 & $8 / 15 / 11$ & 8.0 & 9.0 & 3.7 & 1.71 & 0.00 & 0.11 & 6.8 & 0.006 & 2.9 & 252.9 & 1.4 \\
\hline 5682 & $9 / 1 / 10$ & 13.0 & 24.5 & 5.0 & 10.73 & 75.28 & 4.18 & 136.0 & 0.009 & 1.5 & 61.0 & 5.4 \\
\hline 5690 & $8 / 17 / 11$ & 15.0 & 33.0 & 7.6 & 15.73 & 91.70 & 1.60 & 37.9 & 0.012 & 1.4 & 37.6 & 10.9 \\
\hline 5710 & $8 / 17 / 11$ & 7.0 & NA & 5.3 & 1.75 & 6.31 & 0.15 & 50.0 & 0.012 & 3.1 & 150.9 & 2.2 \\
\hline 5780 & $8 / 30 / 11$ & 7.0 & 7.0 & 2.7 & 5.18 & 8.93 & 0.38 & 14.2 & 0.010 & 1.6 & 331.6 & 1.6 \\
\hline 5814 & 8/18/11 & 5.0 & NA & 2.2 & 2.78 & 3.09 & 0.12 & 25.7 & 0.011 & 0.8 & 21.5 & 15.2 \\
\hline 9685 & $8 / 16 / 11$ & 5.0 & 8.0 & 2.6 & 2.31 & 6.08 & 0.10 & 105.2 & 0.014 & 3.2 & 2651.5 & 0.1 \\
\hline 9931 & $8 / 31 / 10$ & 18.0 & NA & 20.3 & 1.91 & 2.74 & 0.08 & 8.5 & 0.014 & 0.8 & 4.2 & 45.0 \\
\hline \multicolumn{13}{|l|}{ LEA } \\
\hline 5780 & $7 / 11 / 13$ & NA & NA & NA & 5.18 & 8.93 & 0.38 & 14.2 & 0.010 & 1.8 & 218.2 & 1.2 \\
\hline 3418 & $6 / 18 / 13$ & 6.0 & 13.0 & 3.3 & 7.31 & 31.62 & 0.49 & 6.7 & 0.016 & 2.8 & 299.1 & 1.4 \\
\hline 5780 & $7 / 11 / 13$ & 8.0 & 17.0 & 2.4 & 5.18 & 8.93 & 0.38 & 14.2 & 0.010 & 1.1 & 128.8 & 3.2 \\
\hline
\end{tabular}


Table C1.1: Continued

\begin{tabular}{|c|c|c|c|c|c|c|c|c|c|c|c|c|}
\hline Midas & & $\begin{array}{c}\text { Epi. P, } \\
\text { ppb }\end{array}$ & $\begin{array}{c}\text { Hypo. P, } \\
\text { ppb }\end{array}$ & $\begin{array}{c}\mathrm{CHL} \\
\mathbf{a}\end{array}$ & $\begin{array}{c}\text { Ag:WA } \\
\text { ratio }\end{array}$ & $\begin{array}{c}\text { AdjAg:LA } \\
\text { ratio } \\
\end{array}$ & $\begin{array}{c}\text { Ag:LA } \\
\text { ratio }\end{array}$ & WA:LA & Road:WA & $A \mathbf{l}_{\mathrm{NaOH}}: \mathrm{Fe}_{\mathrm{BD}}$ & $\mathbf{A l}_{\mathrm{NaOH}}: \mathbf{P}_{\mathrm{BD}}$ & $\mathbf{P}_{\mathrm{BD}}$ \\
\hline 3130 & $7 / 18 / 13$ & 9.0 & 13.0 & 4.3 & 5.35 & 11.41 & 0.35 & 6.4 & 0.016 & 3.3 & 123.5 & 3.0 \\
\hline 3382 & $7 / 9 / 13$ & 4.0 & 17.0 & 1.5 & 1.45 & 0.00 & 0.04 & 3.1 & 0.015 & 3.3 & 70.8 & 2.5 \\
\hline 3424 & $7 / 3 / 13$ & 7.0 & 12.5 & 2.2 & 10.18 & 22.62 & 1.67 & 17.3 & 0.010 & 5.3 & 123.4 & 2.2 \\
\hline 3199 & $7 / 12 / 13$ & 5.0 & 10.5 & 1.8 & 0.54 & 4.63 & 0.06 & 35.9 & 0.009 & 1.3 & 103.9 & 3.1 \\
\hline 3134 & $6 / 27 / 13$ & 12.0 & 6.0 & 3.6 & 3.39 & 18.20 & 0.30 & 16.0 & 0.011 & 2.9 & 104.0 & 2.6 \\
\hline 3416 & $6 / 18 / 13$ & 16.0 & 12.0 & 2.8 & 8.41 & 35.51 & 0.69 & 8.4 & 0.018 & 3.1 & 161.5 & 3.6 \\
\hline 9685 & $7 / 11 / 13$ & 6.0 & 13.0 & 2.3 & 2.31 & 6.08 & 0.10 & 105.2 & 0.014 & 2.9 & 131.1 & 1.8 \\
\hline 3420 & $7 / 17 / 13$ & 11.0 & 21.0 & 3.5 & 6.18 & 17.87 & 0.46 & 7.4 & 0.012 & 3.3 & 96.6 & 5.8 \\
\hline 3454 & 7/1/13 & NA & NA & NA & 3.41 & 8.50 & 0.17 & 9.6 & 0.011 & 2.8 & 184.4 & 2.1 \\
\hline 5582 & $8 / 26 / 13$ & 9.0 & 10.0 & 6.5 & 4.70 & 36.70 & 1.19 & 24.5 & 0.016 & 5.4 & 101.8 & 3.9 \\
\hline 3134 & $6 / 27 / 13$ & 4.0 & 22.0 & 1.6 & 3.39 & 18.20 & 0.30 & 16.0 & 0.011 & 1.4 & 106.3 & 3.3 \\
\hline 5780 & $7 / 11 / 13$ & 7.0 & 17.5 & 2.5 & 5.18 & 8.93 & 0.38 & 14.2 & 0.010 & 1.6 & 75.9 & 4.8 \\
\hline 5780 & $7 / 11 / 13$ & 4.0 & 17.0 & 2.0 & 5.18 & 8.93 & 0.38 & 14.2 & 0.010 & 2.0 & 121.3 & 2.6 \\
\hline 3132 & $7 / 18 / 13$ & 4.0 & 18.0 & 1.8 & 0.73 & 0.00 & 0.03 & 4.1 & 0.011 & 2.4 & 101.8 & 2.5 \\
\hline 3126 & $7 / 18 / 13$ & 8.0 & 8.5 & 6.3 & 3.61 & 12.53 & 0.28 & 8.2 & 0.016 & 4.5 & 56.1 & 5.6 \\
\hline 3234 & $7 / 1 / 13$ & 7.0 & 14.0 & 2.8 & 1.45 & 4.85 & 0.19 & 13.3 & 0.012 & 3.2 & 88.5 & 5.2 \\
\hline 3374 & $6 / 24 / 13$ & 4.0 & 20.0 & 2.5 & 0.64 & 0.61 & 0.03 & 4.6 & 0.006 & 2.2 & 40.9 & 5.2 \\
\hline 3134 & $6 / 27 / 13$ & NA & NA & NA & 3.39 & 18.20 & 0.30 & 16.0 & 0.011 & 3.0 & 154.1 & 2.0 \\
\hline 3452 & $7 / 31 / 13$ & 8.0 & 19.0 & 2.3 & 6.58 & 17.48 & 0.90 & 14.1 & 0.010 & 1.9 & 158.4 & 2.6 \\
\hline 3454 & 7/1/13 & 5.0 & 15.0 & 2.6 & 3.41 & 8.50 & 0.17 & 9.6 & 0.011 & 3.6 & 168.8 & 2.6 \\
\hline 3448 & $8 / 1 / 13$ & 9.0 & 13.5 & 4.2 & 3.86 & 60.13 & 0.64 & 16.9 & 0.008 & 6.2 & 158.4 & 2.6 \\
\hline 3232 & $7 / 16 / 13$ & 6.0 & 12.5 & 3.3 & 2.78 & 17.75 & 0.38 & 13.9 & 0.012 & 3.9 & 138.7 & 3.5 \\
\hline 3456 & $9 / 10 / 13$ & 12.0 & 7.7 & 3.0 & 1.83 & 3.88 & 0.15 & 8.4 & 0.008 & 2.3 & 285.4 & 2.5 \\
\hline 5780 & $7 / 11 / 13$ & NA & NA & NA & 5.18 & 8.93 & 0.38 & 14.2 & 0.010 & 1.4 & 96.6 & 3.9 \\
\hline
\end{tabular}


Table C1.2: Significant Parameters: Physiochemical and Climate. Parameters used for model regression consisting of epilimnetic and hypolimnetic $\mathrm{P}$, chl a; morphometry and climate parameters: $Z_{\text {avg }}, S c h, \mathrm{~T}_{\text {hyp }}, \mathrm{OI}$; and water chemistry parameters such as: DOC and $\mathrm{pH}$.

\begin{tabular}{|c|c|c|c|c|c|c|c|c|c|}
\hline Midas & $\begin{array}{c}\text { Epi. P, } \\
\text { ppb }\end{array}$ & $\begin{array}{c}\text { Нypo. P, } \\
\text { ppb }\end{array}$ & $\begin{array}{c}\text { CHL } \\
\text { a }\end{array}$ & Zavg & Sch & Thyp & DOC & pH & OI \\
\hline \multicolumn{10}{|l|}{2015} \\
\hline 78 & 4.0 & 3.4 & 1.6 & 30.6 & 1719.5 & 6.0 & 2.7 & 7.1 & 7.4 \\
\hline 177 & 5.2 & 4.6 & 3.3 & 7.7 & 6.5 & 22.0 & 4.4 & 6.7 & 0.9 \\
\hline 224 & 1.9 & 2.6 & $<1$ & 37.7 & 2141.0 & 6.1 & 2.0 & 7.0 & 11.5 \\
\hline 3444 & 3.5 & 4.9 & 2.1 & 24.7 & 880.6 & 7.8 & 3.2 & 7.2 & 3.2 \\
\hline 3446 & 4.2 & 9.1 & 2.7 & 10.0 & 316.7 & 11.7 & 2.7 & 7.1 & 4.3 \\
\hline 3748 & 6.1 & 20.7 & 2.3 & 24.0 & 866.8 & 7.6 & 2.6 & 7.4 & 4.3 \\
\hline 3750 & 5.1 & 9.2 & 3.2 & 8.2 & 152.6 & 9.9 & 3.9 & 7.6 & 3.9 \\
\hline 3796 & 19.2 & NA & 22.1 & 2.8 & 3.0 & 23.0 & 3.3 & 7.4 & 1.4 \\
\hline 3838 & 5.5 & 9.1 & 2.4 & 22.2 & 508.6 & 6.0 & 3.1 & 7.1 & 5.4 \\
\hline 3916 & 4.0 & 13.2 & 2.4 & 7.3 & 100.1 & 11.1 & 2.4 & 7.0 & 3.8 \\
\hline 4434 & 2.6 & 2.4 & 1.4 & 46.7 & 2785.3 & 4.9 & 2.5 & 6.4 & 7.7 \\
\hline 4538 & 4.4 & 5.5 & 1.6 & 12.6 & 172.3 & 7.5 & 2.6 & 6.9 & NA \\
\hline 5172 & 12.6 & 10.6 & 25.3 & 7.2 & 18.8 & 19.1 & 5.9 & 7.3 & 2.0 \\
\hline 5190 & 3.3 & 4.3 & 1.2 & 23.6 & 1423.6 & 5.5 & 2.0 & 7.4 & 9.2 \\
\hline 5272 & 5.3 & 53.3 & 4.6 & 24.4 & 577.7 & 5.4 & 3.4 & 7.1 & 8.5 \\
\hline 5274 & 6.8 & 8.1 & 4.3 & 14.1 & 147.8 & 14.4 & 3.3 & 7.0 & 1.4 \\
\hline 5280 & 7.5 & 19.6 & 3.5 & 24.8 & 477.5 & 6.8 & 3.8 & 7.1 & 2.8 \\
\hline 5344 & 19.0 & 15.3 & 5.2 & 2.5 & 4.6 & 23.1 & 3.2 & 7.2 & 1.6 \\
\hline 5348 & 9.3 & NA & 2.9 & 4.7 & 0.2 & 23.8 & 3.4 & 7.7 & 3.8 \\
\hline 5349 & 12.6 & NA & 3.6 & 3.8 & 31.6 & 23.6 & 3.0 & 7.3 & 2.0 \\
\hline 5352 & 10.7 & 23.7 & 5.0 & 8.6 & 197.6 & 10.9 & 3.2 & 7.8 & 5.6 \\
\hline 5400 & 7.5 & 14.2 & 5.4 & 25.9 & 513.5 & 8.0 & 3.5 & 6.9 & 6.1 \\
\hline 5408 & 21.0 & 280.0 & 6.4 & 8.1 & 90.2 & 11.7 & 3.8 & 8.2 & 2.4 \\
\hline 5448 & 13.9 & 33.3 & 17.1 & 16.7 & 439.7 & 8.8 & 3.9 & 8.9 & 3.8 \\
\hline \multicolumn{10}{|l|}{2016} \\
\hline 3688 & 6.4 & 11.5 & 3.5 & NA & NA & 10.6 & NA & 6.9 & NA \\
\hline 3760 & 8.5 & 11.5 & 1.2 & NA & NA & 9.4 & NA & 6.3 & NA \\
\hline 3762 & 5.3 & 10.3 & 1.1 & NA & NA & 7.3 & NA & 7.4 & NA \\
\hline 3824 & 18.6 & NA & 0.9 & NA & NA & 24.7 & NA & 6.4 & NA \\
\hline 3826 & 8.0 & NA & 6.9 & NA & NA & 25.3 & NA & NA & NA \\
\hline 4346 & 17.2 & NA & 1.9 & NA & NA & 22.4 & NA & 6.4 & NA \\
\hline 4406 & 20.0 & 310.0 & 5.8 & NA & NA & 11.5 & NA & 7.3 & NA \\
\hline 4444 & 12.0 & NA & 3.6 & NA & NA & 20.1 & NA & 7.2 & NA \\
\hline 4446 & 14.5 & NA & 1.9 & NA & NA & 22 & NA & 7.4 & NA \\
\hline 4448 & 4.8 & NS & 3.8 & NA & NA & 14.8 & NA & 7.4 & NA \\
\hline
\end{tabular}


Table C1.2: Conditions

\begin{tabular}{|c|c|c|c|c|c|c|c|c|c|}
\hline Midas & $\begin{array}{c}\text { Epi. P, } \\
\text { ppb }\end{array}$ & $\begin{array}{c}\text { Hypo. P, } \\
\text { ppb }\end{array}$ & $\begin{array}{c}\text { CHL } \\
\mathbf{a} \\
\end{array}$ & Zavg & Sch & Thyp & DOC & pH & OI \\
\hline 5182 & 23.1 & 9.3 & 0.9 & NA & NA & 5.9 & NA & 6.9 & NA \\
\hline 5184 & 8.8 & 16.1 & 0.0 & NA & NA & 18.3 & NA & 7.2 & NA \\
\hline 5186 & 5.0 & 13.1 & 2.4 & NA & NA & 12.5 & NA & 7.4 & NA \\
\hline 5330 & 23.1 & NA & 0.9 & NA & NA & 23.6 & NA & 7.4 & NA \\
\hline 5664 & 9.3 & NA & 1.9 & NA & NA & 23.8 & NA & 6.3 & NA \\
\hline 5666 & 9.0 & 20.3 & 1.8 & NA & NA & 16.1 & NA & 7.3 & NA \\
\hline 5812 & 6.5 & 11.8 & 1.0 & NA & NA & 5.7 & NA & 6.7 & NA \\
\hline 5814 & 5.7 & 11.1 & 0.0 & NA & NA & 6.5 & NA & 7.1 & NA \\
\hline \multicolumn{10}{|l|}{ DEP } \\
\hline 70 & 9.0 & NA & 6.2 & 3.0 & 8.1 & 23.9 & 4.2 & 7.3 & 1.9 \\
\hline 80 & 13.0 & NA & 3.1 & NA & NA & 22.7 & 7.0 & 7.2 & NA \\
\hline 121 & 6.0 & 14.0 & 4.4 & 10.6 & 17.9 & 14.3 & 4.4 & 7.1 & 2.1 \\
\hline 177 & 6.0 & NA & 2.1 & 7.7 & 1.2 & 16.2 & 4.0 & 6.9 & 0.9 \\
\hline 243 & 4.0 & NA & 2.1 & 12.8 & 210.3 & 10.7 & 3.8 & 6.8 & 3.7 \\
\hline 262 & 9.0 & NA & 2.4 & 13.4 & 122.1 & 10.8 & 3.5 & 7.0 & 5.2 \\
\hline 342 & 3.0 & NA & 1.7 & 22.1 & 401.4 & 6.1 & 3.2 & 6.9 & 4.8 \\
\hline 386 & 15.0 & 42.0 & 4.9 & 5.0 & 4.3 & 12.7 & 3.2 & NA & 6.0 \\
\hline 410 & 10.0 & NA & 4.6 & NA & NA & 19.1 & 3.7 & 7.0 & NA \\
\hline 447 & 7.0 & NA & 1.7 & 1.1 & 0.2 & 19.4 & 5.1 & 6.7 & NA \\
\hline 760 & 10.0 & NA & 4.1 & 3.3 & 0.0 & 22.7 & 4.0 & 7.6 & NA \\
\hline 954 & 4.0 & NA & 1.9 & 22.5 & 61.3 & 14.6 & 5.2 & 6.6 & 1.4 \\
\hline 1068 & 6.0 & NA & 1.9 & 3.7 & 2.3 & 21.6 & 2.9 & 7.0 & 3.2 \\
\hline 1070 & 5.0 & NA & 2.4 & 29.3 & 280.9 & 10.5 & 3.8 & 6.9 & 1.4 \\
\hline 1078 & 9.0 & NA & 3.3 & 3.8 & 2.3 & 22.5 & 5.8 & 6.6 & 0.8 \\
\hline 1088 & 8.0 & NA & 2.1 & 12.8 & 231.1 & 9.3 & 4.6 & 6.9 & 4.0 \\
\hline 1150 & 4.0 & NA & 1.9 & 27.4 & 136.6 & 12.4 & 3.1 & 6.9 & 1.7 \\
\hline 1210 & 6.0 & 10.0 & 1.8 & 11.9 & 26.0 & 13.3 & 4.6 & 6.5 & 2.6 \\
\hline 2004 & 5.0 & NA & 1.4 & 3.2 & 5.5 & 20.5 & 3.5 & 6.9 & 3.3 \\
\hline 2020 & 5.0 & NA & 1.8 & 19.6 & 174.6 & 11.2 & 3.8 & 7.0 & 1.4 \\
\hline 2146 & 6.0 & NA & 2.3 & 11.3 & 135.2 & 11.5 & 3.7 & 6.9 & 4.0 \\
\hline 2156 & 15.0 & NA & 7.2 & 2.9 & 1.6 & 22.8 & 6.3 & 7.6 & 2.8 \\
\hline 2242 & 5.0 & NA & 1.9 & 5.1 & 17.6 & 17.6 & 3.4 & 7.6 & 3.2 \\
\hline 2286 & 33.0 & NA & 34.0 & 2.7 & 8.7 & 22.0 & 6.7 & 9.1 & 2.6 \\
\hline 2590 & 7.0 & 12.0 & 3.0 & 10.8 & 50.5 & 13.2 & 4.8 & 7.3 & 1.3 \\
\hline 2608 & 6.0 & 17.0 & 5.0 & 13.4 & 258.4 & 8.8 & 3.4 & 7.4 & 7.5 \\
\hline 2948 & 5.0 & NA & 2.3 & 24.5 & 223.1 & 9.1 & 6.0 & 7.0 & 2.4 \\
\hline 3038 & 7.0 & NA & 3.6 & 7.8 & 1.7 & 21.7 & 6.4 & 7.1 & 2.3 \\
\hline 3376 & 14.0 & NA & 7.7 & 7.4 & 77.9 & 6.1 & 4.2 & NA & 11.9 \\
\hline 3388 & 6.0 & NA & 2.6 & 3.5 & 0.7 & 23.0 & 3.2 & 7.1 & 4.2 \\
\hline 3434 & 9.0 & 14.0 & 2.5 & 9.3 & 105.2 & 12.5 & 3.3 & 7.6 & 3.2 \\
\hline
\end{tabular}


Table C1.2: Continued

\begin{tabular}{|c|c|c|c|c|c|c|c|c|c|}
\hline Midas & $\begin{array}{c}\text { Epi. P, } \\
\text { ppb }\end{array}$ & $\begin{array}{c}\text { Hypo. P, } \\
\text { ppb }\end{array}$ & $\begin{array}{c}\text { CHL } \\
\mathbf{a} \\
\end{array}$ & Zavg & Sch & Thyp & DOC & $\mathbf{p H}$ & OI \\
\hline 3452 & 6.0 & NA & 2.2 & 10.3 & 519.4 & 8.4 & 4.4 & 7.0 & 8.2 \\
\hline 3454 & 6.0 & 14.0 & 2.9 & 9.7 & 54.4 & 11.7 & 3.2 & 6.6 & 2.8 \\
\hline 3604 & 5.0 & 9.0 & 4.2 & 8.5 & 260.2 & 10.1 & 3.5 & NA & 5.8 \\
\hline 3626 & 8.0 & 16.0 & 2.1 & 7.5 & 152.2 & 5.8 & 3.7 & 7.9 & 14.6 \\
\hline 3672 & 7.0 & 9.0 & 8.0 & 5.4 & 166.6 & 12.1 & 3.1 & 7.1 & 2.9 \\
\hline 3682 & 6.0 & NA & 3.6 & 18.8 & 527.1 & 5.1 & 2.4 & 7.0 & 6.0 \\
\hline 3690 & 7.0 & 13.0 & 3.4 & 8.2 & 56.6 & 10.4 & 2.8 & 7.3 & 4.8 \\
\hline 3780 & 8.0 & NA & 4.5 & 5.4 & 8.3 & 14.9 & 3.6 & 6.8 & 8.4 \\
\hline 3814 & 16.0 & 82.0 & 32.0 & 3.2 & 38.3 & 16.3 & 3.5 & 7.8 & 5.0 \\
\hline 3830 & 7.0 & 42.0 & 3.7 & 5.1 & 14.3 & 13.5 & 4.1 & 7.5 & 5.3 \\
\hline 3884 & 13.0 & NA & 4.4 & 3.3 & 2.9 & 21.2 & 4.8 & 7.0 & 7.2 \\
\hline 3920 & 10.0 & 11.0 & 1.5 & 8.1 & 603.6 & 10.2 & 2.5 & 7.1 & 4.5 \\
\hline 4272 & 5.0 & 10.0 & 2.1 & 3.9 & 63.3 & 11.9 & 3.9 & 6.8 & 7.1 \\
\hline 4316 & 11.0 & 30.0 & 4.2 & 5.1 & 24.5 & 15.0 & 3.6 & 7.0 & 5.8 \\
\hline 4322 & 5.0 & 12.0 & 3.4 & 10.4 & 130.6 & 8.1 & 2.8 & 6.8 & 7.5 \\
\hline 4328 & 3.0 & NA & 1.5 & 27.8 & 459.7 & 10.5 & 2.6 & 6.9 & 3.2 \\
\hline 4330 & 10.0 & NA & 2.9 & 2.1 & 2.4 & 22.8 & 3.0 & 6.8 & 4.6 \\
\hline 4336 & 9.0 & NA & 3.2 & 4.2 & 7.3 & 22.8 & 3.8 & 6.9 & 2.7 \\
\hline 4388 & 7.0 & 12.0 & 4.5 & 6.4 & 32.5 & 13.7 & 4.7 & 6.7 & 3.0 \\
\hline 4452 & 3.0 & NA & 2.3 & 7.2 & 3.5 & 17.4 & 2.5 & 6.8 & 20.4 \\
\hline 4492 & 5.0 & 7.0 & 2.0 & 11.1 & 77.0 & 13.4 & 4.0 & 6.7 & 4.9 \\
\hline 4606 & 2.0 & NA & 0.9 & 21.0 & 306.6 & 10.4 & 1.8 & 6.7 & 10.1 \\
\hline 4608 & 2.0 & NA & 0.9 & 21.6 & 1392.1 & 6.0 & 1.7 & 6.8 & 29.6 \\
\hline 4610 & 4.0 & 11.0 & 2.4 & 8.1 & 51.8 & 7.8 & 4.1 & 6.5 & 13.9 \\
\hline 4612 & 4.0 & 6.0 & 2.3 & 8.3 & 16.8 & 10.0 & 4.5 & 6.5 & 10.1 \\
\hline 4614 & 5.0 & 24.0 & 2.0 & 5.0 & 5.7 & 12.0 & 5.5 & 6.4 & 5.9 \\
\hline 4618 & 12.0 & NA & 3.4 & 3.2 & 5.1 & 13.8 & 7.5 & 6.6 & 12.1 \\
\hline 4620 & 7.0 & NA & 2.8 & 3.2 & 2.1 & 19.3 & 5.0 & 6.2 & 8.7 \\
\hline 4622 & 2.0 & NA & 1.9 & 30.2 & 69.8 & 10.0 & 2.9 & 6.6 & 0.9 \\
\hline 4624 & 4.0 & 6.0 & 2.0 & 13.6 & 79.6 & 11.6 & 2.8 & 6.9 & 7.8 \\
\hline 4628 & 8.0 & NA & 2.0 & 3.9 & 4.3 & 18.6 & 8.1 & 6.3 & 9.0 \\
\hline 4630 & 3.0 & 8.0 & 2.1 & 9.7 & 13.5 & 13.9 & 4.3 & 6.7 & 4.8 \\
\hline 4766 & 8.0 & NA & 2.8 & 13.1 & 4.1 & 19.1 & 6.1 & 6.7 & 1.1 \\
\hline 4782 & 8.0 & NA & 3.9 & 1.2 & 0.4 & 20.1 & 7.0 & 6.4 & NA \\
\hline 4788 & 6.0 & NA & 2.5 & 4.8 & 0.2 & 22.0 & 3.8 & NA & NA \\
\hline 4800 & 6.0 & 13.0 & 2.3 & 5.4 & 34.6 & 15.1 & 3.2 & 7.0 & 6.0 \\
\hline 4802 & 11.0 & NA & 4.7 & 2.5 & 0.1 & 23.3 & 3.9 & 7.0 & 3.0 \\
\hline 4806 & 17.0 & NA & 6.8 & 3.2 & 0.0 & 23.5 & 2.4 & 6.8 & 3.7 \\
\hline 4822 & 13.0 & 57.0 & 14.0 & 4.3 & 62.6 & 13.8 & 2.5 & 7.5 & 5.8 \\
\hline 4852 & 6.0 & NA & 6.2 & 13.7 & 140.9 & 8.8 & 2.7 & 6.9 & 3.2 \\
\hline
\end{tabular}


Table C1.2: Continued

\begin{tabular}{|c|c|c|c|c|c|c|c|c|c|}
\hline Midas & $\begin{array}{c}\text { Epi. P, } \\
\text { ppb }\end{array}$ & $\begin{array}{c}\text { Hypo. P, } \\
\text { ppb }\end{array}$ & $\begin{array}{c}\text { CHL } \\
\mathbf{a} \\
\end{array}$ & Zavg & Sch & Thyp & DOC & $\mathbf{p H}$ & OI \\
\hline 4857 & 9.0 & 15.0 & 4.2 & 5.7 & 24.2 & 10.7 & 5.3 & 6.3 & 4.9 \\
\hline 4894 & 6.0 & NA & 2.3 & 7.0 & 5.5 & 22.1 & 3.0 & 6.8 & 3.3 \\
\hline 4896 & 6.0 & NA & 2.0 & 27.0 & 1033.9 & 5.7 & 4.3 & 7.1 & 6.4 \\
\hline 5024 & 5.0 & 22.0 & 2.1 & 16.1 & 276.7 & 5.2 & 2.5 & 7.1 & 5.5 \\
\hline 5172 & 18.0 & 34.0 & 61.0 & 7.2 & 47.8 & 15.9 & 6.2 & 8.2 & 2.0 \\
\hline 5174 & 16.0 & NA & 5.5 & 2.8 & 0.3 & 22.4 & 4.5 & 7.2 & 1.2 \\
\hline 5198 & 12.0 & NA & 3.5 & 2.4 & 7.1 & 23.1 & 3.7 & 7.2 & 6.6 \\
\hline 5222 & 10.0 & 22.0 & 3.8 & 11.9 & 262.4 & 8.4 & 3.9 & 6.6 & 6.3 \\
\hline 5236 & 12.0 & 24.5 & 11.0 & 23.7 & 247.3 & 9.8 & 3.5 & 7.9 & 1.7 \\
\hline 5240 & 8.0 & 17.0 & 2.7 & 13.9 & 155.8 & 6.5 & 3.1 & 7.6 & 4.4 \\
\hline 5280 & 9.0 & NA & 4.0 & 24.8 & 504.1 & 7.2 & 3.7 & 7.2 & 2.8 \\
\hline 5344 & 18.0 & NA & 4.5 & 2.5 & 0.3 & 23.7 & 3.3 & 6.9 & 1.5 \\
\hline 5348 & 9.0 & NA & 3.2 & 4.7 & 16.4 & 22.9 & 3.3 & NA & 3.8 \\
\hline 5349 & 15.0 & NA & 11.0 & 3.8 & 4.7 & 23.5 & 2.9 & 7.0 & 2.0 \\
\hline 5352 & 11.0 & 187.0 & 6.9 & 8.6 & 206.0 & 13.3 & 3.4 & 8.0 & $\mathrm{NA}$ \\
\hline 5386 & 12.0 & NA & 3.4 & 2.6 & 12.9 & 22.7 & 4.7 & 7.2 & 2.8 \\
\hline 5400 & 7.0 & NA & 4.5 & 25.9 & 492.2 & 9.6 & 3.6 & 7.2 & 3.5 \\
\hline 5408 & 32.0 & 300.0 & 19.0 & 8.1 & 41.8 & 13.9 & 4.0 & NA & 2.4 \\
\hline 5416 & 35.0 & 55.0 & 53.0 & 6.9 & 14.8 & 16.9 & 4.0 & 8.4 & 2.5 \\
\hline 5448 & 18.0 & 38.5 & 28.0 & 16.7 & 281.4 & 11.7 & 3.7 & 7.8 & 3.8 \\
\hline 5458 & 12.0 & NA & 5.5 & 4.2 & 30.8 & 20.1 & 5.4 & 8.0 & 3.5 \\
\hline 5490 & 8.0 & 9.0 & 3.7 & 4.8 & 24.9 & 13.2 & 3.5 & 6.8 & 4.9 \\
\hline 5682 & 13.0 & 24.5 & 5.0 & 12.4 & 150.2 & 11.4 & 5.1 & 7.3 & 4.1 \\
\hline 5690 & 15.0 & 33.0 & 7.6 & 7.2 & 87.2 & 12.3 & 5.0 & 6.9 & 5.7 \\
\hline 5710 & 7.0 & NA & 5.3 & 9.0 & 355.0 & 9.8 & 4.5 & 6.7 & 8.8 \\
\hline 5780 & 7.0 & 7.0 & 2.7 & 10.8 & 133.0 & 12.2 & 3.5 & 6.9 & 1.8 \\
\hline 5814 & 5.0 & NA & 2.2 & 29.3 & 272.5 & 5.7 & 3.4 & 7.0 & 3.6 \\
\hline 9685 & 5.0 & 8.0 & 2.6 & 8.9 & 46.6 & 13.5 & 3.6 & NA & 3.2 \\
\hline 9931 & 18.0 & NA & 20.3 & 9.9 & 75.9 & 13.1 & 3.0 & 7.4 & 3.7 \\
\hline \multicolumn{10}{|l|}{ LEA } \\
\hline 5780 & NA & NA & NA & 10.8 & NA & NA & NA & NA & $\mathrm{NA}$ \\
\hline 3418 & 6.0 & 13.0 & 3.3 & 6.2 & 138.3 & 11.0 & NA & 6.7 & 5.7 \\
\hline 5780 & 8.0 & 17.0 & 2.4 & 10.8 & 133.1 & 17.7 & NA & 6.7 & NA \\
\hline 3130 & 9.0 & 13.0 & 4.3 & 9.0 & 120.8 & 9.2 & NA & 6.7 & 5.5 \\
\hline 3382 & 4.0 & 17.0 & 1.5 & 7.5 & 422.6 & 9.7 & NA & 6.6 & 9.8 \\
\hline 3424 & 7.0 & 12.5 & 2.2 & 6.6 & 138.8 & 9.1 & NA & 6.9 & 8.9 \\
\hline 3199 & 5.0 & 10.5 & 1.8 & 5.9 & 106.6 & 7.5 & NA & 6.8 & 13.7 \\
\hline 3134 & 12.0 & 6.0 & 3.6 & 3.5 & 348.5 & 19.6 & NA & 6.7 & NA \\
\hline 3416 & 16.0 & 12.0 & 2.8 & 5.4 & 221.1 & 9.4 & NA & 6.6 & 6.2 \\
\hline 9685 & 6.0 & 13.0 & 2.3 & 8.9 & 66.2 & 15.6 & NA & 6.7 & 3.2 \\
\hline
\end{tabular}


Table C1.2: Continued

\begin{tabular}{|cccccccccc|}
\hline Midas & $\begin{array}{c}\text { Epi. P, } \\
\text { ppb }\end{array}$ & $\begin{array}{c}\text { Hypo. P, } \\
\text { ppb }\end{array}$ & $\begin{array}{c}\text { CHL } \\
\mathbf{a}\end{array}$ & Zavg & Sch & Thyp & DOC & pH & OI \\
\hline 3420 & 11.0 & 21.0 & 3.5 & 12.1 & 437.8 & 5.0 & NA & 6.8 & 11.0 \\
3454 & NA & NA & NA & 9.7 & NA & NA & NA & NA & 2.8 \\
5582 & 9.0 & 10.0 & 6.5 & 7.4 & 119.9 & 7.8 & NA & 6.7 & 8.1 \\
3134 & 4.0 & 22.0 & 1.6 & 13.6 & 817.5 & 9.8 & NA & 6.7 & 5.0 \\
5780 & 7.0 & 17.5 & 2.5 & 10.8 & 584.2 & 12.8 & NA & 6.8 & 1.8 \\
5780 & 4.0 & 17.0 & 2.0 & 10.8 & 511.5 & 13.8 & NA & 6.8 & NA \\
3132 & 4.0 & 18.0 & 1.8 & 13.0 & 172.7 & 8.0 & NA & 6.7 & 3.5 \\
3126 & 8.0 & 8.5 & 6.3 & 5.1 & 15.1 & 15.8 & NA & 6.6 & 6.4 \\
3234 & 7.0 & 14.0 & 2.8 & 6.6 & 238.4 & 7.1 & NA & 6.6 & 8.7 \\
3374 & 4.0 & 20.0 & 2.5 & 9.2 & 423.8 & 8.4 & NA & 6.9 & 6.7 \\
3134 & NA & NA & NA & 3.5 & NA & NA & NA & NA & 2.7 \\
3452 & 8.0 & 19.0 & 2.3 & 10.3 & 400.3 & 7.1 & NA & 6.9 & 8.2 \\
3454 & 5.0 & 15.0 & 2.6 & 9.7 & 68.1 & 13.1 & NA & 6.7 & NA \\
3448 & 9.0 & 13.5 & 4.2 & 11.1 & 114.3 & 8.1 & NA & 6.7 & 7.0 \\
3232 & 6.0 & 12.5 & 3.3 & 7.7 & 125.6 & 9.1 & NA & 6.6 & 7.1 \\
3456 & 12.0 & 7.7 & 3.0 & 3.9 & 70.6 & 16.7 & NA & 6.6 & 4.3 \\
5780 & NA & NA & NA & 10.8 & NA & NA & NA & NA & NA
\end{tabular}


Table C2: Model Parameters: Coefficient of determination, $\mathrm{R}^{2}$. For significant parameters used for model regression. Negative sign (-) indicates negative correlation for $\mathrm{R}$ value.

\begin{tabular}{|c|c|c|c|c|c|c|c|c|c|c|c|c|c|c|}
\hline & $\begin{array}{l}\log \\
\text { Epi } P\end{array}$ & $\begin{array}{c}\log \\
\text { Hypo P }\end{array}$ & $\begin{array}{c}\log \\
\text { Chl a }\end{array}$ & WA:LA & OI & $\begin{array}{c}\log \\
\mathrm{Al}: \mathrm{P}\end{array}$ & $\mathrm{Al}: \mathrm{Fe}$ & $\log P_{\mathrm{BD}}$ & $\underset{\text { Zavg }}{\log }$ & $\log S c h$ & Thyp & Ag:WA & $\begin{array}{c}\mathrm{Adj} \\
\mathrm{Ag}: \mathrm{LA}\end{array}$ & Ag:LA \\
\hline $\begin{array}{l}\log \\
\text { Epi P }\end{array}$ & 1.00 & 0.57 & 0.69 & 0.01 & (-) 0.45 & (-) 0.25 & (-) 0.01 & 0.23 & (-) 0.5 & (-) 0.38 & 0.39 & 0.42 & 0.37 & 0.17 \\
\hline $\begin{array}{c}\log \\
\text { Нypo P }\end{array}$ & & 1.00 & 0.36 & 0.12 & (-) 0.11 & (-) 0.33 & (-) 0.00 & 0.44 & (-) 0.12 & (-) 0.06 & 0.01 & 0.38 & 0.43 & 0.03 \\
\hline $\begin{array}{c}\log \\
\text { Chl a }\end{array}$ & & & 1.00 & 0.09 & (-) 0.40 & (-) 0.29 & (-) 0.02 & 0.21 & (-) 0.28 & (-) 0.23 & 0.24 & 0.51 & 0.41 & 0.43 \\
\hline WA:LA & & & & 1.00 & 0.02 & (-) 0.13 & (-) 0.04 & 0.18 & 0.05 & 0.02 & (-) 0.06 & 0.09 & (-) 0.00 & 0.14 \\
\hline OI & & & & & 1.00 & 0.12 & 0.00 & (-) 0.05 & 0.49 & 0.42 & (-) 0.49 & (-) 0.23 & (-) 0.11 & (-) 0.12 \\
\hline $\begin{array}{c}\log \\
\text { Al:P }\end{array}$ & & & & & & 1.00 & 0.31 & (-) 0.85 & 0.00 & (-) 0.00 & (-) 0.00 & (-) 0.39 & (-) 0.25 & (-) 0.13 \\
\hline $\mathrm{Al}: \mathrm{Fe}$ & & & & & & & 1.00 & (-) 0.18 & (-) 0.03 & (-) 0.01 & 0.00 & (-) 0.05 & (-) 0.04 & (-) 0.03 \\
\hline $\begin{array}{l}\log \\
P_{\text {во }}\end{array}$ & & & & & & & & 1.00 & 0.00 & 0.00 & (-) 0.01 & 0.35 & 0.26 & 0.09 \\
\hline $\begin{array}{c}\log \\
\text { Zavg }\end{array}$ & & & & & & & & & 1.00 & 0.76 & (-) 0.79 & (-) 0.06 & (-) 0.03 & (-) 0.08 \\
\hline $\log S c h$ & & & & & & & & & & 1.00 & (-) 0.85 & (-) 0.03 & (-) 0.02 & (-) 0.07 \\
\hline Thyp & & & & & & & & & & & 1.00 & 0.02 & 0.01 & 0.06 \\
\hline Ag:WA & & & & & & & & & & & & 1.00 & 0.46 & 0.56 \\
\hline $\begin{array}{c}\text { Adj } \\
\text { Ag:LA }\end{array}$ & & & & & & & & & & & & & 1.00 & 0.10 \\
\hline $\mathrm{Ag}: \mathrm{LA}$ & & & & & & & & & & & & & & 1.00 \\
\hline
\end{tabular}


Table C2 continued: Coefficient of Determination, $\mathrm{R}^{2}$. MPJ and SPJ represent the maximum and cumulative precipitation from January in inches, respectively; MPM and SPM represent the maximum and cumulative precipitation from May in inches, respectively.

\begin{tabular}{|c|c|c|c|c|c|c|c|c|}
\hline & Rd:WA & $\begin{array}{l}\text { Wtlnd: } \\
\text { WA }\end{array}$ & DOC & $\mathrm{pH}$ & MPJ & SPJ & MPM & SPM \\
\hline $\begin{array}{l}\log \\
\text { Epi } P\end{array}$ & 0.07 & 0.03 & 0.29 & 0.33 & (-) 0.04 & (-) 0.12 & (-) 0.15 & (-) 0.15 \\
\hline $\begin{array}{c}\log \\
\text { Hypo P }\end{array}$ & 0.11 & 0.00 & 0.11 & 0.41 & (-) 0.10 & (-) 0.11 & (-) 0.23 & (-) 0.15 \\
\hline $\begin{array}{c}\log \\
\text { Chl a }\end{array}$ & 0.01 & 0.12 & 0.56 & 0.23 & (-) 0.03 & (-) 0.27 & (-) 0.11 & (-) 0.3 \\
\hline WA:LA & (-) 0.00 & 0.02 & 0.16 & (-) 0.00 & (-) 0.04 & (-) 0.00 & (-) 0.05 & (-) 0.00 \\
\hline OI & (-) 0.01 & (-) 0.35 & (-) 0.34 & (-) 0.03 & (-) 0.00 & 0.21 & 0.00 & 0.19 \\
\hline $\begin{array}{l}\log \\
\text { Al:P }\end{array}$ & (-) 0.05 & (-) 0.07 & (-) 0.15 & (-) 0.24 & 0.12 & 0.09 & 0.20 & 0.13 \\
\hline $\mathrm{Al}: \mathrm{Fe}$ & 0.01 & (-) 0.10 & (-) 0.05 & (-) 0.00 & 0.03 & 0.00 & 0.04 & 0.01 \\
\hline$\underset{P_{\mathrm{BD}}}{\log }$ & 0.12 & 0.01 & 0.11 & 0.33 & (-) 0.16 & (-) 0.07 & (-) 0.28 & (-) 0.11 \\
\hline $\begin{array}{l}\log \\
\text { Zavg }\end{array}$ & (-) 0.15 & (-) 0.08 & (-) 0.11 & (-) 0.06 & 0.01 & 0.03 & 0.02 & 0.04 \\
\hline $\log S c h$ & (-) 0.04 & (-) 0.16 & (-) 0.18 & (-) 0.02 & (-) 0.00 & 0.01 & 0.00 & 0.01 \\
\hline Thyp & 0.02 & 0.18 & 0.17 & 0.01 & 0.00 & (-) 0.00 & (-) 0.00 & (-) 0.00 \\
\hline Ag:WA & 0.05 & 0.04 & 0.46 & 0.30 & $(-0) 0.14$ & (-) 0.23 & (-) 0.24 & (-) 0.23 \\
\hline $\begin{array}{c}\text { Adj } \\
\text { Ag:LA }\end{array}$ & 0.02 & (-) 0.00 & 0.07 & 0.34 & (-) 0.08 & (-) 0.18 & (-) 0.13 & (-) 0.15 \\
\hline Ag:LA & 0.00 & 0.04 & 0.58 & 0.04 & (-) 0.05 & (-) 0.20 & (-) 0.09 & (-) 0.20 \\
\hline Rd:WA & 1.00 & (-) 0.06 & (-) 0.01 & 0.12 & (-) 0.33 & 0.00 & (-) 0.21 & 0.00 \\
\hline $\begin{array}{l}\text { Wtlnd: } \\
\text { WA }\end{array}$ & & 1.00 & 0.37 & (-) 0.01 & 0.06 & (-) 0.03 & 0.04 & (-) 0.03 \\
\hline DOC & & & 1.00 & 0.06 & 0.00 & (-) 0.19 & (-) 0.01 & (-) 0.22 \\
\hline $\mathrm{pH}$ & & & & 1.00 & (-) 0.15 & (-) 0.19 & (-) 0.34 & (-) 0.25 \\
\hline MPJ & & & & & 1.00 & 0.00 & 0.88 & 0.00 \\
\hline SPJ & & & & & & 1.00 & 0.03 & 0.96 \\
\hline MPM & & & & & & & 1.00 & 0.05 \\
\hline SPM & & & & & & & & 1.00 \\
\hline
\end{tabular}




\section{APPENDIX D: LAND COVER DATA}

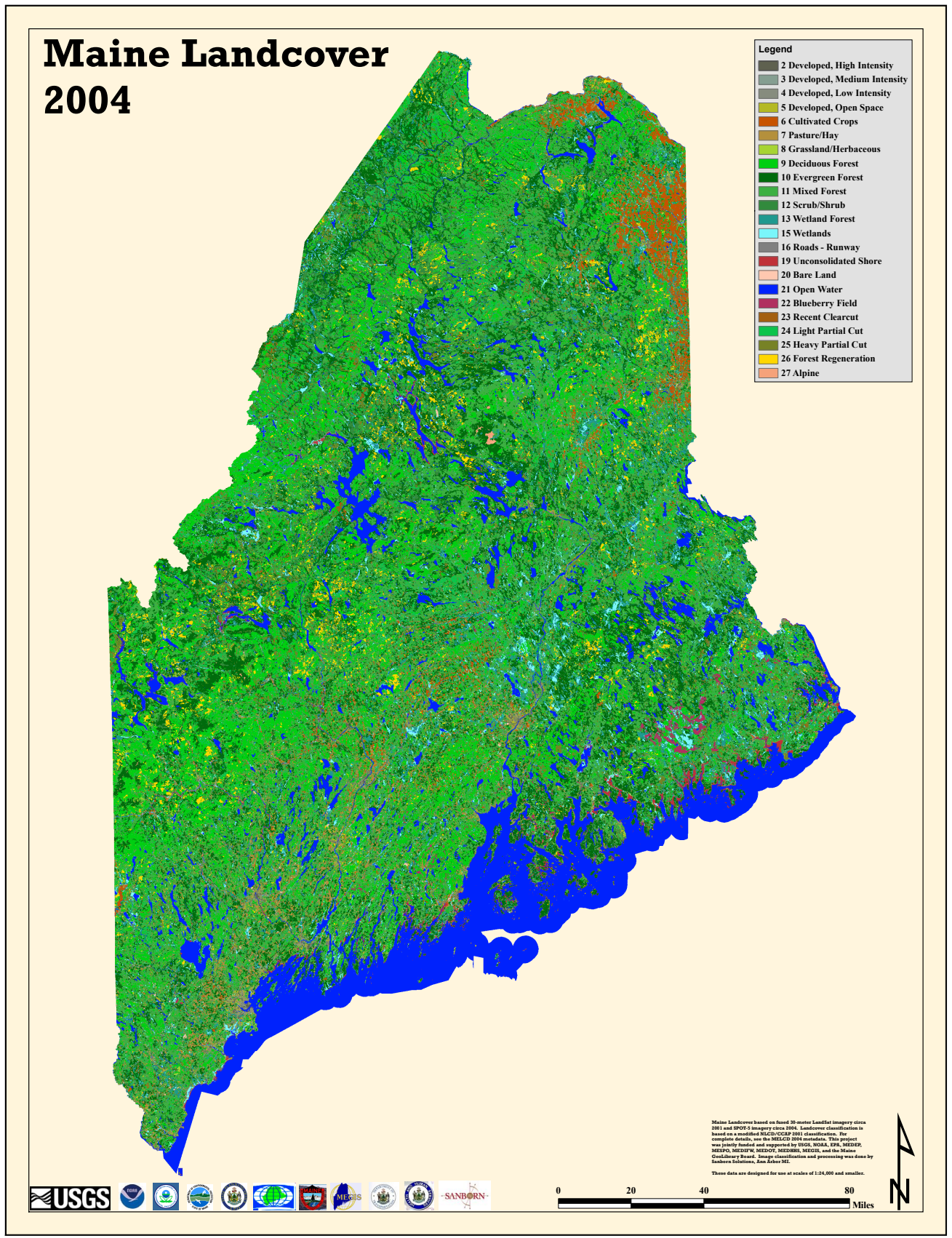

Figure D1: Land cover Map 2004 (MEGIS). The map is derived from the Landsat Thematic Mapper $(5,7)$ imagery, from 1999-2001. The map was refined to the state of Maine requirements using SPOT 5 panchromatic imagery from 2004. 
Table D1: Land cover Identification Key.

\begin{tabular}{|c|l|}
\hline Key & Land cover Type \\
\hline 2 & Developed, High Intensity \\
3 & Developed, Medium Intensity \\
4 & Developed, Low Intensity \\
6 & Developed, Open Space \\
7 & Cultivated Crops \\
8 & Pasture/ Hay \\
9 & Grassland/ Herbaceous \\
10 & Deciduous Forest \\
11 & Evergreen Forest \\
12 & Sixed Forest \\
13 & Wetland Forest \\
15 & Wetlands \\
16 & Roads/ Runway \\
19 & Unconsolidated Shore \\
20 & Bare Land \\
21 & Open Water \\
22 & Blueberry Field \\
23 & Recent Clearcut \\
24 & Light Partial Cut \\
25 & Heavy Partial Cut \\
26 & Forest Regeneration \\
27 & Alpine \\
\hline
\end{tabular}


Table D2.1: Land cover Area (ha.) from type 2 to 12. Land cover area (hectare) data from 2004, with identification code in Table D1.

\begin{tabular}{|c|c|c|c|c|c|c|c|c|c|c|c|}
\hline Midas & 2 & 3 & 4 & 5 & 6 & 7 & 8 & 9 & 10 & 11 & 12 \\
\hline \multicolumn{12}{|l|}{2015} \\
\hline 78 & 10.6 & 5.0 & 19.6 & 0.0 & 0.5 & 0.8 & 0.0 & 1357.1 & 167.5 & 670.5 & 11.4 \\
\hline 177 & 9.8 & 12.4 & 14.5 & 3.5 & 130.5 & 26.6 & 0.0 & 796.1 & 649.5 & 2032.1 & 25.9 \\
\hline 224 & 0.2 & 0.0 & 0.5 & 0.0 & 0.0 & 0.0 & 0.0 & 251.0 & 422.2 & 133.1 & 0.0 \\
\hline 3444 & 8.8 & 17.2 & 56.5 & 4.6 & 65.5 & 504.2 & 11.2 & 1661.7 & 1501.4 & 3833.7 & 34.8 \\
\hline 3446 & 0.7 & 5.7 & 14.7 & 0.0 & 13.0 & 53.5 & 11.1 & 108.7 & 275.6 & 740.9 & 13.6 \\
\hline 3748 & 15.3 & 26.2 & 16.9 & 29.3 & 42.9 & 285.9 & 1.1 & 606.6 & 269.4 & 910.8 & 50.6 \\
\hline 3750 & 3.3 & 12.2 & 53.8 & 4.8 & 32.3 & 371.1 & 10.2 & 519.1 & 396.3 & 1624.7 & 14.6 \\
\hline 3796 & 16.0 & 42.7 & 96.4 & 82.7 & 194.7 & 960.7 & 4.9 & 734.9 & 738.3 & 2365.4 & 47.1 \\
\hline 3838 & 17.0 & 19.5 & 68.6 & 5.2 & 40.0 & 313.3 & 1.4 & 416.7 & 895.6 & 2602.0 & 122.7 \\
\hline 3916 & 1.0 & 0.4 & 0.8 & 0.0 & 7.1 & 13.3 & 0.0 & 190.6 & 117.6 & 291.3 & 6.1 \\
\hline 4434 & 0.0 & 00.0 & 0.0 & 0.0 & 0.1 & 0.6 & 0.0 & 76.5 & 1254.6 & 615.6 & 30.8 \\
\hline 4538 & 0.0 & 0.0 & 0.0 & 0.0 & 0.6 & 0.0 & 0.3 & 346.5 & 218.8 & 53.7 & 2.4 \\
\hline 5172 & 45.6 & 83.5 & 164.5 & 29.9 & 1309.6 & 2227.4 & 9.8 & 4315.6 & 5242.8 & 7157.4 & 25.9 \\
\hline 5190 & 0.2 & 0.4 & 7.7 & 0.0 & 0.0 & 15.4 & 0.0 & 897.9 & 81.2 & 181.2 & 8.5 \\
\hline 5272 & 17.7 & 19.5 & 41.3 & 7.2 & 75.1 & 80.6 & 0.0 & 1313.7 & 724.1 & 2083.2 & 7.0 \\
\hline 5274 & 31.6 & 37.4 & 103.7 & 57.4 & 191.8 & 237.1 & 6.2 & 1499.4 & 1015.4 & 3782.6 & 10.6 \\
\hline 5280 & 70.0 & 85.6 & 216.1 & 11.0 & 319.3 & 749.4 & 5.3 & 1395.2 & 1222.9 & 4099.2 & 29.8 \\
\hline 5344 & 6.3 & 11.2 & 25.1 & 0.0 & 231.1 & 212.0 & 0.0 & 1297.5 & 336.5 & 1492.2 & 2.5 \\
\hline 5348 & 5.3 & 18.6 & 27.2 & 1.7 & 23.1 & 6.8 & 6.3 & 275.5 & 46.9 & 361.9 & 8.8 \\
\hline 5349 & 4.5 & 5.6 & 8.8 & 0.0 & 13.0 & 11.0 & 0.0 & 217.7 & 224.5 & 612.8 & 2.3 \\
\hline 5352 & 11.9 & 16.4 & 39.0 & 0.0 & 46.0 & 15.3 & 0.0 & 173.9 & 60.5 & 381.2 & 0.2 \\
\hline 5400 & 16.2 & 30.7 & 63.1 & 8.2 & 186.2 & 800.3 & 4.4 & 2731.7 & 1307.2 & 3105.6 & 127.5 \\
\hline 5408 & 7.5 & 6.4 & 52.4 & 45.5 & 100.5 & 209.4 & 6.0 & 887.3 & 63.7 & 613.4 & 18.3 \\
\hline 5448 & 26.5 & 51.0 & 142.0 & 45.6 & 212.7 & 657.4 & 2.1 & 1353.0 & 652.5 & 2320.5 & 68.4 \\
\hline \multicolumn{12}{|l|}{ DEP } \\
\hline 70 & 11.4 & 13.2 & 41.6 & 40.5 & 272.4 & 325.3 & 2.7 & 417.4 & 823.5 & 1292.4 & 1.5 \\
\hline 80 & NA & NA & NA & NA & NA & NA & NA & NA & NA & NA & NA \\
\hline 121 & NA & NA & NA & NA & NA & NA & NA & NA & NA & NA & NA \\
\hline 177 & 9.8 & 12.4 & 14.5 & 3.5 & 130.5 & 26.6 & 0.0 & 796.1 & 649.5 & 2032.1 & 25.9 \\
\hline 243 & 0.0 & 0.0 & 0.0 & 0.0 & 0.0 & 0.0 & 0.0 & 1089.2 & 701.6 & 2179.9 & 221.2 \\
\hline 262 & 0.2 & 0.4 & 1.2 & 0.0 & 0.0 & 0.0 & 0.0 & 219.2 & 140.0 & 292.5 & 36.0 \\
\hline 342 & 0.0 & 0.0 & 0.0 & 26.8 & 0.0 & 0.0 & 0.0 & 457.3 & 325.5 & 568.0 & 29.6 \\
\hline 386 & 0.2 & 0.8 & 0.0 & 0.3 & 0.0 & 0.0 & 0.0 & 98.5 & 0.0 & 123.5 & 8.0 \\
\hline 410 & 0.0 & 0.0 & 0.0 & 0.0 & 0.0 & 0.0 & 0.0 & 1245.0 & 758.4 & 1205.4 & 258.3 \\
\hline 447 & 2.9 & 0.3 & 5.7 & 0.0 & 0.0 & 0.0 & 1.4 & 0.0 & 217.4 & 32.2 & 13.8 \\
\hline 760 & 0.0 & 0.7 & 1.2 & 0.0 & 55.1 & 8.9 & 0.0 & 165.9 & 94.4 & 521.3 & 0.2 \\
\hline 954 & 0.4 & 2.4 & 0.0 & 0.0 & 0.0 & 22.8 & 7.4 & 1686.9 & 3449.8 & 3364.0 & 1503.1 \\
\hline 1068 & 1.4 & 0.9 & 1.6 & 2.8 & 36.3 & 6.2 & 0.0 & 255.8 & 121.5 & 260.7 & 12.3 \\
\hline
\end{tabular}


Table D2.1: Continued

\begin{tabular}{|c|c|c|c|c|c|c|c|c|c|c|c|}
\hline Midas & 2 & 3 & 4 & 5 & 6 & 7 & 8 & 9 & 10 & 11 & 12 \\
\hline 1070 & NA & NA & NA & NA & NA & NA & NA & NA & NA & NA & NA \\
\hline 1078 & 0.1 & 1.9 & 1.7 & 0.9 & 2.9 & 6.1 & 1.1 & 597.8 & 5934.1 & 3954.7 & 44.3 \\
\hline 1088 & 0.0 & 1.1 & 0.6 & 0.0 & 4.5 & 0.7 & 0.0 & 641.9 & 1315.5 & 1600.3 & 5.2 \\
\hline 1150 & 0.6 & 1.0 & 0.2 & 0.0 & 0.0 & 0.0 & 0.0 & 428.9 & 3204.3 & 3203.5 & 28.7 \\
\hline 1210 & 1.2 & 2.2 & 0.0 & 0.0 & 0.0 & 1.9 & 0.4 & 398.2 & 1234.5 & 1005.7 & 62.0 \\
\hline 2004 & 0.0 & 1.2 & 0.8 & 0.0 & 0.0 & 0.0 & 0.0 & 271.9 & 315.9 & 247.9 & 48.2 \\
\hline 2020 & 0.8 & 6.7 & 1.8 & 0.0 & 0.0 & 0.0 & 5.9 & 1384.7 & 7593.9 & 4166.3 & 512.1 \\
\hline 2146 & 5.2 & 2.6 & 10.1 & 2.6 & 15.0 & 15.0 & 0.5 & 804.9 & 658.2 & 1131.4 & 21.3 \\
\hline 2156 & 1.5 & 5.7 & 15.5 & 7.9 & 515.9 & 123.6 & 26.7 & 376.5 & 275.8 & 1005.0 & 27.6 \\
\hline 2242 & 0.6 & 2.0 & 1.3 & 0.0 & 7.0 & 24.0 & 0.0 & 264.6 & 138.1 & 629.8 & 18.9 \\
\hline 2286 & 40.2 & 67.8 & 179.7 & 123.3 & 477.3 & 807.8 & 19.5 & 4162.6 & 2630.4 & 4645.4 & 55.3 \\
\hline 2590 & 16.1 & 15.7 & 20.9 & 3.2 & 608.8 & 538.7 & 5.0 & 4512.4 & 3511.2 & 8237.0 & 123.5 \\
\hline 2608 & 0.5 & 3.1 & 1.7 & 0.0 & 20.8 & 5.4 & 1.4 & 814.2 & 17.2 & 463.4 & 0.0 \\
\hline 2948 & 0.0 & 0.0 & 0.0 & 0.0 & 0.0 & 0.0 & 0.0 & 2341.0 & 1710.5 & 2485.4 & 291.5 \\
\hline 3038 & 0.0 & 1.1 & 0.0 & 0.0 & 100.8 & 48.7 & 24.2 & 1150.3 & 1045.5 & 2699.0 & 173.6 \\
\hline 3376 & 0.0 & 0.2 & 7.3 & 0.0 & 0.0 & 2.0 & 0.0 & 14.0 & 51.9 & 111.7 & 0.0 \\
\hline 3388 & 0.3 & 0.2 & 2.5 & 0.0 & 1.4 & 11.1 & 0.0 & 65.9 & 28.4 & 126.5 & 0.0 \\
\hline 3434 & 6.7 & 9.8 & 17.9 & 0.0 & 30.9 & 351.3 & 0.2 & 472.4 & 449.7 & 1355.4 & 1.1 \\
\hline 3452 & 5.4 & 8.3 & 28.2 & 3.4 & 45.9 & 109.2 & 0.9 & 170.1 & 365.6 & 719.7 & 33.9 \\
\hline 3454 & 0.8 & 30.7 & 8.9 & 2.3 & 13.4 & 76.6 & 0.2 & 410.9 & 250.5 & 834.5 & 30.7 \\
\hline 3604 & 0.0 & 1.6 & 0.3 & 0.3 & 44.7 & 96.6 & 0.2 & 821.3 & 912.3 & 1298.5 & 23.3 \\
\hline 3626 & 0.3 & 0.2 & 0.1 & 0.1 & 0.0 & 3.2 & 0.0 & 13.4 & 3.8 & 91.2 & 1.9 \\
\hline 3672 & 4.1 & 13.1 & 8.9 & 158.8 & 77.8 & 42.3 & 27.1 & 7418.9 & 4668.1 & 2228.3 & 118.7 \\
\hline 3682 & 9.3 & 12.4 & 48.2 & 7.7 & 56.3 & 107.5 & 0.0 & 3818.2 & 596.1 & 914.7 & 21.5 \\
\hline 3690 & 0.0 & 0.4 & 4.3 & 0.0 & 7.0 & 26.9 & 0.0 & 498.9 & 71.2 & 457.5 & 1.5 \\
\hline 3780 & 0.0 & 0.0 & 0.0 & 0.0 & 1.4 & 0.0 & 0.0 & 50.2 & 2.5 & 3.4 & 0.1 \\
\hline 3814 & 0.2 & 2.6 & 6.0 & 0.0 & 4.0 & 108.7 & 0.0 & 162.5 & 52.7 & 234.9 & 1.0 \\
\hline 3830 & 1.7 & 1.7 & 3.1 & 0.0 & 67.3 & 68.7 & 2.6 & 290.6 & 339.2 & 1077.4 & 5.7 \\
\hline 3884 & 1.5 & 0.0 & 1.3 & 5.9 & 0.0 & 8.5 & 0.0 & 0.0 & 0.3 & 36.5 & 0.1 \\
\hline 3920 & 0.2 & 0.2 & 6.2 & 2.6 & 8.3 & 50.0 & 1.1 & 253.8 & 81.3 & 389.6 & 18.3 \\
\hline 4272 & 0.0 & 1.7 & 0.0 & 0.0 & 1.6 & 0.0 & 0.0 & 67.9 & 56.7 & 26.1 & 2.6 \\
\hline 4316 & 5.8 & 11.5 & 23.3 & 0.5 & 149.4 & 124.1 & 0.8 & 1676.5 & 879.5 & 1183.2 & 68.3 \\
\hline 4322 & 1.9 & 0.3 & 4.4 & 0.0 & 3.7 & 0.0 & 0.0 & 242.5 & 64.0 & 85.3 & 12.7 \\
\hline 4328 & 4.6 & 6.4 & 10.0 & 9.4 & 86.8 & 50.2 & 17.6 & 2515.6 & 1585.1 & 780.7 & 100.9 \\
\hline 4330 & 0.0 & 1.3 & 0.0 & 0.0 & 5.0 & 0.2 & 0.0 & 306.1 & 30.0 & 58.7 & 0.0 \\
\hline 4336 & 7.3 & 15.1 & 24.6 & 12.6 & 54.7 & 85.2 & 5.0 & 970.0 & 1470.3 & 1449.1 & 47.4 \\
\hline 4388 & 1.8 & 2.0 & 2.0 & 0.0 & 12.8 & 3.0 & 5.0 & 128.8 & 757.1 & 580.9 & 45.2 \\
\hline 4452 & 0.0 & 0.0 & 0.0 & 0.0 & 0.0 & 0.0 & 4.4 & 0.0 & 80.2 & 54.7 & 10.4 \\
\hline 4492 & NA & NA & NA & NA & NA & NA & NA & NA & NA & NA & NA \\
\hline 4606 & 0.3 & 2.4 & 0.4 & 0.0 & 0.0 & 0.0 & 4.7 & 0.2 & 149.7 & 285.4 & 15.1 \\
\hline 4608 & 0.8 & 0.5 & 0.4 & 0.0 & 0.0 & 0.0 & 14.3 & 3.2 & 122.4 & 153.4 & 35.6 \\
\hline
\end{tabular}


Table D2.1: Continued

\begin{tabular}{|c|c|c|c|c|c|c|c|c|c|c|c|}
\hline Midas & 2 & 3 & 4 & 5 & 6 & 7 & 8 & 9 & 10 & 11 & 12 \\
\hline 4610 & 0.0 & 0.0 & 0.0 & 0.0 & 0.0 & 0.0 & 0.0 & 0.0 & 72.8 & 4.5 & 4.0 \\
\hline 4612 & 0.9 & 0.4 & 0.0 & 0.0 & 0.0 & 0.0 & 6.6 & 0.0 & 136.9 & 93.9 & 24.2 \\
\hline 4614 & NA & NA & NA & NA & NA & NA & NA & NA & NA & NA & NA \\
\hline 4618 & 0.0 & 0.0 & 1.6 & 0.0 & 0.0 & 0.0 & 0.7 & 0.0 & 52.2 & 1.6 & 1.3 \\
\hline 4620 & 0.0 & 0.0 & 0.0 & 0.0 & 0.0 & 0.0 & 0.0 & 0.0 & 77.8 & 6.8 & 0.0 \\
\hline 4622 & 0.9 & 1.7 & 3.3 & 0.0 & 0.0 & 0.0 & 4.4 & 31.9 & 830.2 & 245.6 & 5.7 \\
\hline 4624 & 0.1 & 1.8 & 1.8 & 0.0 & 0.0 & 0.0 & 4.2 & 0.8 & 258.2 & 147.6 & 13.2 \\
\hline 4628 & 0.0 & 1.0 & 5.2 & 3.3 & 0.0 & 0.0 & 3.2 & 0.0 & 84.0 & 17.1 & 1.3 \\
\hline 4630 & 5.7 & 5.0 & 7.3 & 0.0 & 0.0 & 0.0 & 7.3 & 0.0 & 364.8 & 265.7 & 1.9 \\
\hline 4766 & 0.0 & 0.0 & 0.0 & 0.0 & 0.0 & 20.0 & 4.5 & 246.8 & 4326.2 & 2423.7 & 81.3 \\
\hline 4782 & 0.0 & 0.0 & 0.0 & 0.0 & 1.9 & 0.0 & 0.0 & 172.2 & 875.9 & 808.7 & 0.0 \\
\hline 4788 & 0.0 & 0.0 & 0.0 & 0.0 & 0.0 & 0.0 & 0.0 & 79.1 & 65.5 & 202.8 & 33.1 \\
\hline 4800 & 1.3 & 0.9 & 5.1 & 0.0 & 2.7 & 29.9 & 0.0 & 169.0 & 1.8 & 10.0 & 2.6 \\
\hline 4802 & NA & NA & NA & NA & NA & NA & NA & NA & NA & NA & NA \\
\hline 4806 & 0.0 & 0.7 & 3.3 & 0.0 & 0.0 & 81.4 & 0.0 & 527.2 & 27.7 & 31.9 & 6.2 \\
\hline 4822 & 11.6 & 13.3 & 46.4 & 14.7 & 28.3 & 53.1 & 0.0 & 387.7 & 3.1 & 60.5 & 1.0 \\
\hline 4852 & 5.7 & 7.9 & 26.3 & 0.0 & 0.2 & 321.1 & 1.5 & 2189.7 & 420.6 & 621.5 & 42.2 \\
\hline 4857 & 1.1 & 0.0 & 0.8 & 0.0 & 0.0 & 12.4 & 0.0 & 195.9 & 191.8 & 177.9 & 9.4 \\
\hline 4894 & 0.1 & 4.4 & 5.0 & 4.1 & 8.3 & 13.5 & 0.0 & 63.4 & 146.4 & 364.9 & 0.0 \\
\hline 4896 & 1.5 & 12.6 & 34.4 & 4.0 & 141.9 & 73.7 & 0.0 & 2273.7 & 811.5 & 2504.1 & 16.0 \\
\hline 5024 & 4.4 & 4.6 & 37.0 & 0.0 & 8.2 & 37.0 & 0.0 & 242.0 & 121.8 & 548.1 & 59.2 \\
\hline 5172 & 45.6 & 83.5 & 164.5 & 29.9 & 1309.6 & 2227.4 & 9.8 & 4315.6 & 5242.8 & 7157.4 & 25.9 \\
\hline 5174 & 0.2 & 5.9 & 11.3 & 0.0 & 14.5 & 99.0 & 0.0 & 514.9 & 78.4 & 390.3 & 4.1 \\
\hline 5198 & 0.7 & 0.5 & 7.9 & 0.0 & 12.9 & 96.4 & 0.4 & 120.6 & 103.0 & 182.8 & 1.6 \\
\hline 5222 & 3.5 & 11.3 & 18.6 & 15.7 & 7.4 & 157.9 & 13.7 & 587.6 & 772.9 & 2210.9 & 36.6 \\
\hline 5236 & 23.3 & 41.0 & 79.6 & 152.1 & 132.5 & 1451.2 & 3.5 & 1123.3 & 930.6 & 2621.8 & 54.3 \\
\hline 5240 & 0.8 & 2.4 & 8.2 & 0.0 & 2.8 & 46.5 & 0.0 & 104.0 & 110.1 & 214.4 & 7.5 \\
\hline 5280 & 70.0 & 85.6 & 216.1 & 11.0 & 319.3 & 749.4 & 5.3 & 1395.2 & 1222.9 & 4099.2 & 29.8 \\
\hline 5344 & 6.3 & 11.2 & 25.1 & 0.0 & 231.1 & 212.0 & 0.0 & 1297.5 & 336.5 & 1492.2 & 2.5 \\
\hline 5348 & 5.3 & 18.6 & 27.2 & 1.7 & 23.1 & 6.8 & 6.3 & 275.5 & 46.9 & 361.9 & 8.8 \\
\hline 5349 & 4.5 & 5.6 & 8.8 & 0.0 & 13.0 & 11.0 & 0.0 & 217.7 & 224.5 & 612.8 & 2.3 \\
\hline 5352 & 11.9 & 16.4 & 39.0 & 0.0 & 46.0 & 15.3 & 0.0 & 173.9 & 60.5 & 381.2 & 0.2 \\
\hline 5386 & 1.9 & 8.2 & 10.7 & 0.0 & 107.4 & 129.5 & 18.2 & 738.8 & 250.5 & 1119.0 & 30.5 \\
\hline 5400 & 16.2 & 30.7 & 63.1 & 8.2 & 186.2 & 800.3 & 4.4 & 2731.7 & 1307.2 & 3105.6 & 127.5 \\
\hline 5408 & 7.5 & 6.4 & 52.4 & 45.5 & 100.5 & 209.4 & 6.0 & 887.3 & 63.7 & 613.4 & 18.3 \\
\hline 5416 & 9.5 & 14.7 & 58.3 & 7.7 & 96.5 & 133.8 & 0.2 & 819.7 & 89.3 & 782.9 & 15.9 \\
\hline 5448 & 26.5 & 51.0 & 142.0 & 45.6 & 212.7 & 657.4 & 2.1 & 1353.0 & 652.5 & 2320.5 & 68.4 \\
\hline 5458 & 9.3 & 7.4 & 26.0 & 0.0 & 49.2 & 97.3 & 0.8 & 597.2 & 397.7 & 1611.5 & 6.8 \\
\hline 5490 & 0.0 & 0.0 & 0.0 & 0.0 & 7.2 & 0.0 & 0.0 & 254.9 & 24.0 & 36.6 & 9.1 \\
\hline 5682 & 17.9 & 37.8 & 63.0 & 0.0 & 25.6 & 1015.3 & 3.1 & 2819.7 & 1264.3 & 2287.5 & 106.3 \\
\hline 5690 & 7.0 & 7.7 & 27.9 & 5.1 & 57.9 & 149.4 & 19.5 & 368.9 & 66.9 & 298.4 & 18.4 \\
\hline
\end{tabular}


Table D2.1: Continued

\begin{tabular}{|c|c|c|c|c|c|c|c|c|c|c|c|}
\hline Midas & 2 & 3 & 4 & 5 & 6 & 7 & 8 & 9 & 10 & 11 & 12 \\
\hline 5710 & 2.1 & 4.1 & 4.2 & 0.0 & 5.9 & 15.6 & 0.0 & 258.0 & 100.1 & 582.7 & 1.6 \\
\hline 5780 & 98.5 & 74.1 & 227.4 & 86.2 & 116.2 & 693.8 & 4.5 & 1231.8 & 1688.8 & 4887.0 & 39.5 \\
\hline 5814 & 7.6 & 7.6 & 18.0 & 0.0 & 18.5 & 34.9 & 0.0 & 293.1 & 300.7 & 567.4 & 0.2 \\
\hline 9685 & 18.2 & 21.1 & 61.5 & 100.6 & 20.5 & 7.8 & 0.0 & 160.3 & 99.3 & 353.8 & 2.7 \\
\hline 9931 & 4.4 & 1.9 & 16.6 & 4.0 & 9.4 & 13.0 & 0.2 & 370.7 & 3.3 & 100.7 & 2.1 \\
\hline \multicolumn{12}{|l|}{ LEA } \\
\hline 5780 & 98.5 & 74.1 & 227.4 & 86.2 & 116.2 & 693.8 & 4.5 & 1231.8 & 1688.8 & 4887.0 & 39.5 \\
\hline 3418 & 2.0 & 1.6 & 0.9 & 0.0 & 3.7 & 83.6 & 0.0 & 69.7 & 278.3 & 268.4 & 1.1 \\
\hline 5780 & 98.5 & 74.1 & 227.4 & 86.2 & 116.2 & 693.8 & 4.5 & 1231.8 & 1688.8 & 4887.0 & 39.5 \\
\hline 3130 & 0.5 & 0.6 & 0.0 & 0.0 & 1.7 & 31.5 & 0.0 & 32.1 & 81.2 & 139.8 & 0.2 \\
\hline 3382 & 0.0 & 1.0 & 8.6 & 3.2 & 0.0 & 5.6 & 0.0 & 40.4 & 16.6 & 146.3 & 0.0 \\
\hline 3424 & 0.2 & 0.6 & 0.0 & 0.0 & 4.7 & 121.6 & 0.0 & 185.4 & 113.5 & 625.6 & 0.0 \\
\hline 3199 & 0.0 & 0.0 & 0.0 & 0.0 & 4.2 & 0.0 & 0.0 & 316.0 & 17.9 & 125.7 & 0.0 \\
\hline 3134 & 3.0 & 9.8 & 19.7 & 13.5 & 49.0 & 138.1 & 33.7 & 663.4 & 393.8 & 1640.6 & 22.0 \\
\hline 3416 & 4.9 & 3.5 & 9.0 & 0.0 & 5.5 & 121.9 & 1.9 & 37.8 & 289.4 & 493.1 & 0.0 \\
\hline 9685 & 18.2 & 21.1 & 61.5 & 100.6 & 20.5 & 7.8 & 0.0 & 160.3 & 99.3 & 353.8 & 2.7 \\
\hline 3420 & 0.2 & 1.8 & 1.3 & 0.0 & 0.3 & 43.7 & 0.0 & 100.5 & 82.7 & 266.1 & 0.0 \\
\hline 3454 & 0.8 & 30.7 & 8.9 & 2.3 & 13.4 & 76.6 & 0.2 & 410.9 & 250.5 & 834.5 & 30.7 \\
\hline 5582 & 0.0 & 4.1 & 5.1 & 0.4 & 3.8 & 28.8 & 0.0 & 61.0 & 77.0 & 243.2 & 11.6 \\
\hline 3134 & 3.0 & 9.8 & 19.7 & 13.5 & 49.0 & 138.1 & 33.7 & 663.4 & 393.8 & 1640.6 & 22.0 \\
\hline 5780 & 98.5 & 74.1 & 227.4 & 86.2 & 116.2 & 693.8 & 4.5 & 1231.8 & 1688.8 & 4887.0 & 39.5 \\
\hline 5780 & 98.5 & 74.1 & 227.4 & 86.2 & 116.2 & 693.8 & 4.5 & 1231.8 & 1688.8 & 4887.0 & 39.5 \\
\hline 3132 & 0.0 & 0.0 & 1.3 & 0.0 & 3.7 & 5.5 & 0.0 & 169.1 & 46.5 & 283.0 & 0.0 \\
\hline 3126 & 0.2 & 2.9 & 0.0 & 0.0 & 0.0 & 14.6 & 0.0 & 5.3 & 44.3 & 168.9 & 0.0 \\
\hline 3234 & 0.0 & 0.8 & 0.0 & 0.0 & 0.4 & 19.0 & 0.0 & 307.5 & 133.6 & 602.6 & 1.2 \\
\hline 3374 & 0.7 & 1.1 & 6.5 & 0.0 & 5.7 & 2.7 & 0.0 & 341.6 & 63.7 & 312.1 & 0.5 \\
\hline 3134 & 3.0 & 9.8 & 19.7 & 13.5 & 49.0 & 138.1 & 33.7 & 663.4 & 393.8 & 1640.6 & 22.0 \\
\hline 3452 & 5.4 & 8.3 & 28.2 & 3.4 & 45.9 & 109.2 & 0.9 & 170.1 & 365.6 & 719.7 & 33.9 \\
\hline 3454 & 0.8 & 30.7 & 8.9 & 2.3 & 13.4 & 76.6 & 0.2 & 410.9 & 250.5 & 834.5 & 30.7 \\
\hline 3448 & 0.0 & 2.3 & 0.6 & 0.0 & 4.0 & 23.7 & 0.4 & 20.2 & 202.3 & 213.9 & 15.1 \\
\hline 3232 & 0.0 & 1.0 & 1.5 & 0.0 & 1.8 & 27.0 & 0.0 & 112.4 & 164.6 & 399.1 & 0.0 \\
\hline 3456 & 0.3 & 2.7 & 2.3 & 2.4 & 6.9 & 21.2 & 0.7 & 47.6 & 222.8 & 332.0 & 3.8 \\
\hline 5780 & 98.5 & 74.1 & 227.4 & 86.2 & 116.2 & 693.8 & 4.5 & 1231.8 & 1688.8 & 4887.0 & 39.5 \\
\hline
\end{tabular}


Table D2.2: Land cover Area (ha.) from type 13 to 27. Land cover area (hectare) data from 2004, with identification code in Table D1.

\begin{tabular}{|c|c|c|c|c|c|c|c|c|c|c|c|c|}
\hline Midas & 13 & 15 & 16 & 19 & 20 & 21 & 22 & 23 & 24 & 25 & 26 & 27 \\
\hline \multicolumn{13}{|l|}{2015} \\
\hline 78 & 34.2 & 23.2 & 111.9 & 6.5 & 3.3 & 644.4 & 0.0 & 20.7 & 534.3 & 231.9 & 639.7 & 0.0 \\
\hline 177 & 1036.0 & 928.4 & 107.7 & 10.0 & 14.5 & 2755.9 & 264.7 & 149.2 & 441.7 & 285.8 & 172.6 & 0.0 \\
\hline 224 & 0.1 & 1.7 & 20.6 & 0.1 & 0.0 & 420.5 & 0.0 & 0.0 & 113.3 & 43.1 & 77.2 & 0.0 \\
\hline 3444 & 299.1 & 141.7 & 267.8 & 0.5 & 15.3 & 1761.2 & 0.0 & 0.0 & 401.5 & 125.5 & 90.4 & 0.0 \\
\hline 3446 & 56.0 & 22.3 & 58.7 & 0.1 & 3.1 & 534.4 & 0.0 & 0.0 & 69.2 & 10.7 & 17.1 & 0.0 \\
\hline 3748 & 22.5 & 36.8 & 101.1 & 0.7 & 66.3 & 952.3 & 0.0 & 0.0 & 79.3 & 37.9 & 6.2 & 0.0 \\
\hline 3750 & 150.2 & 100.1 & 108.0 & 0.2 & 1.5 & 259.4 & 0.0 & 0.0 & 81.8 & 27.7 & 1.2 & 0.0 \\
\hline 3796 & 441.5 & 135.9 & 246.8 & 0.7 & 109.3 & 799.4 & 228.9 & 34.2 & 122.9 & 0.0 & 7403.3 & 0.0 \\
\hline 3838 & 61.3 & 118.8 & 109.1 & 0.2 & 0.7 & 371.0 & 0.0 & 0.0 & 266.2 & 25.9 & 0.0 & 0.0 \\
\hline 3916 & 40.3 & 47.9 & 26.3 & 0.5 & 0.0 & 349.7 & 0.0 & 0.0 & 118.2 & 28.8 & 0.0 & 0.0 \\
\hline 4434 & 14.8 & 38.9 & 8.1 & 26.9 & 0.0 & 792.0 & 0.0 & 0.0 & 6.7 & 28.1 & 42.9 & 0.0 \\
\hline 4538 & 0.0 & 0.0 & 0.0 & 6.5 & 0.0 & 169.2 & 0.0 & 0.0 & 0.0 & 16.7 & 0.0 & 0.0 \\
\hline 5172 & 1451.3 & 475.7 & 573.0 & 47.3 & 8.1 & 1068.5 & 0.0 & 14.3 & 309.7 & 280.5 & 372.4 & 0.0 \\
\hline 5190 & 0.0 & 9.0 & 16.4 & 2.0 & 0.0 & 313.2 & 0.0 & 1.3 & 30.2 & 13.4 & 20.2 & 0.0 \\
\hline 5272 & 195.0 & 34.5 & 53.6 & 13.6 & 0.0 & 1033.3 & 0.0 & 0.0 & 299.3 & 29.6 & 52.0 & 0.0 \\
\hline 5274 & 696.9 & 151.4 & 116.0 & 45.0 & 19.5 & 3434.3 & 0.0 & 0.0 & 272.0 & 102.7 & 67.3 & 0.0 \\
\hline 5280 & 888.4 & 382.5 & 217.1 & 24.4 & 62.0 & 1636.7 & 0.0 & 4.2 & 803.5 & 92.3 & 112.9 & 0.0 \\
\hline 5344 & 237.9 & 176.9 & 91.0 & 13.3 & 28.1 & 1019.2 & 0.0 & 0.0 & 189.3 & 37.0 & 136.0 & 0.0 \\
\hline 5348 & 31.5 & 8.5 & 23.8 & 2.9 & 0.4 & 180.0 & 0.0 & 0.0 & 42.9 & 48.0 & 16.1 & 0.0 \\
\hline 5349 & 13.0 & 38.6 & 27.9 & 13.2 & 0.3 & 689.2 & 0.0 & 0.0 & 33.2 & 0.0 & 0.6 & 0.0 \\
\hline 5352 & 8.9 & 3.0 & 18.5 & 3.5 & 0.2 & 287.0 & 0.0 & 0.0 & 7.9 & 4.1 & 0.0 & 0.0 \\
\hline 5400 & 310.9 & 175.1 & 350.7 & 62.5 & 62.1 & 1841.2 & 95.2 & 0.0 & 103.7 & 49.4 & 64.5 & 0.0 \\
\hline 5408 & 18.6 & 37.4 & 54.8 & 19.2 & 0.9 & 484.2 & 0.0 & 0.0 & 24.5 & 0.0 & 0.2 & 0.0 \\
\hline 5448 & 424.0 & 257.5 & 268.9 & 44.5 & 9.7 & 1578.2 & 0.0 & 0.0 & 65.1 & 52.7 & 49.6 & 0.0 \\
\hline \multicolumn{13}{|l|}{ DEP } \\
\hline 70 & 182.7 & 17.2 & 113.4 & 12.0 & 0.0 & 555.4 & 0.0 & 0.0 & 496.4 & 88.5 & 4.3 & 0.0 \\
\hline 80 & NA & NA & NA & NA & NA & NA & NA & NA & NA & NA & NA & NA \\
\hline 121 & NA & NA & NA & NA & NA & NA & NA & NA & NA & NA & NA & NA \\
\hline 177 & 1036.0 & 928.4 & 107.7 & 10.0 & 14.5 & 2755.9 & 264.7 & 149.2 & 441.7 & 285.8 & 172.6 & 0.0 \\
\hline 243 & 42.3 & 92.3 & 71.2 & 0.2 & 0.2 & 766.7 & 0.0 & 0.0 & 79.6 & 17.3 & 189.2 & 0.0 \\
\hline 262 & 0.0 & 2.8 & 31.3 & 0.1 & 1.4 & 174.2 & 0.0 & 15.4 & 298.0 & 106.6 & 129.9 & 0.0 \\
\hline 342 & 4.4 & 3.8 & 7.1 & 0.2 & 0.0 & 556.4 & 0.0 & 0.6 & 28.3 & 0.0 & 17.8 & 0.0 \\
\hline 386 & 0.0 & 0.0 & 3.2 & 0.0 & 0.3 & 32.6 & 0.0 & 3.6 & 0.0 & 0.0 & 0.0 & 0.0 \\
\hline 410 & 138.0 & 109.1 & 3.6 & 1.2 & 0.6 & 389.4 & 0.0 & 101.6 & 81.1 & 61.4 & 128.5 & 0.0 \\
\hline 447 & 2.7 & 9.3 & 28.0 & 1.5 & 0.0 & 7.4 & 0.0 & 0.0 & 5.2 & 4.5 & 0.0 & 0.0 \\
\hline 760 & 24.5 & 6.3 & 36.6 & 0.0 & 0.0 & 150.4 & 0.0 & 0.0 & 167.6 & 46.6 & 15.8 & 0.0 \\
\hline 954 & 548.1 & 578.8 & 287.4 & 0.2 & 1.4 & 2268.8 & 0.0 & 0.0 & 963.7 & 820.3 & 96.2 & 0.0 \\
\hline 1068 & 13.3 & 3.0 & 38.0 & 0.0 & 0.0 & 237.5 & 0.0 & 0.0 & 18.3 & 31.5 & 21.2 & 0.0 \\
\hline
\end{tabular}


Table D2.2: Continued

\begin{tabular}{|c|c|c|c|c|c|c|c|c|c|c|c|c|}
\hline Midas & 13 & 15 & 16 & 19 & 20 & 21 & 22 & 23 & 24 & 25 & 26 & 27 \\
\hline 1070 & NA & NA & NA & NA & NA & NA & NA & NA & NA & NA & NA & NA \\
\hline 1078 & 2998.9 & 909.1 & 181.0 & 0.0 & 0.6 & 2797.3 & 0.0 & 1.2 & 2543.5 & 1950.6 & 203.2 & 0.0 \\
\hline 1088 & 264.6 & 57.1 & 45.5 & 4.7 & 0.0 & 325.6 & 0.0 & 0.2 & 342.5 & 79.8 & 0.0 & 0.0 \\
\hline 1150 & 84.0 & 278.9 & 31.2 & 369.5 & 0.0 & 5456.0 & 0.0 & 0.0 & 182.2 & 104.6 & 57.9 & 0.0 \\
\hline 1210 & 128.6 & 37.1 & 33.7 & 9.5 & 0.0 & 361.2 & 0.0 & 0.0 & 108.5 & 154.1 & 4.0 & 0.0 \\
\hline 2004 & 0.0 & 0.0 & 10.6 & 0.3 & 0.7 & 273.3 & 0.0 & 0.0 & 90.6 & 6.1 & 42.2 & 0.0 \\
\hline 2020 & 742.9 & 609.8 & 313.4 & 12.5 & 33.5 & 3694.2 & 0.0 & 68.4 & 633.7 & 464.2 & 393.2 & 121.1 \\
\hline 2146 & 66.0 & 35.7 & 78.2 & 0.8 & 1.2 & 1469.8 & 0.0 & 889.3 & 405.7 & 7.7 & 0.0 & 0.0 \\
\hline 2156 & 247.0 & 57.3 & 72.9 & 0.0 & 0.1 & 176.8 & 0.0 & 5.1 & 156.3 & 158.0 & 0.0 & 0.0 \\
\hline 2242 & 10.6 & 27.1 & 30.2 & 27.1 & 0.0 & 202.0 & 0.0 & 0.0 & 226.7 & 4.8 & 4.0 & 0.0 \\
\hline 2286 & 1503.0 & 439.3 & 421.2 & 20.1 & 4.3 & 252.6 & 0.0 & 0.0 & 481.7 & 675.6 & 200.6 & 0.0 \\
\hline 2590 & 360.2 & 564.1 & 894.0 & 0.7 & 1.0 & 1484.0 & 0.0 & 33.4 & 2974.7 & 709.3 & 2353.5 & 0.0 \\
\hline 2608 & 9.4 & 28.0 & 7.4 & 1.4 & 0.0 & 126.4 & 0.0 & 0.0 & 67.9 & 16.9 & 6.5 & 0.0 \\
\hline 2948 & 170.4 & 227.9 & 7.8 & 0.5 & 2.0 & 1348.3 & 0.0 & 42.9 & 525.5 & 378.0 & 104.1 & 0.0 \\
\hline 3038 & 431.4 & 207.8 & 106.3 & 0.0 & 0.0 & 465.3 & 0.0 & 0.0 & 289.3 & 235.0 & 0.0 & 0.0 \\
\hline 3376 & 2.1 & 0.0 & 6.4 & 0.0 & 1.0 & 14.5 & 0.0 & 0.0 & 7.9 & 0.0 & 0.0 & 0.0 \\
\hline 3388 & 8.8 & 3.1 & 18.4 & 0.0 & 3.8 & 66.5 & 0.0 & 0.0 & 8.0 & 1.5 & 0.0 & 0.0 \\
\hline 3434 & 46.9 & 66.0 & 142.1 & 2.0 & 0.0 & 381.9 & 0.0 & 0.0 & 455.8 & 185.2 & 88.2 & 0.0 \\
\hline 3452 & 23.6 & 21.5 & 81.2 & 0.4 & 0.0 & 172.2 & 0.0 & 13.2 & 349.6 & 155.3 & 52.2 & 0.0 \\
\hline 3454 & 1.8 & 44.8 & 86.2 & 0.0 & 0.0 & 532.7 & 0.0 & 0.0 & 177.2 & 89.7 & 44.5 & 0.0 \\
\hline 3604 & 74.2 & 50.4 & 26.9 & 2.5 & 0.0 & 247.0 & 0.0 & 18.7 & 156.9 & 4.6 & 72.2 & 0.0 \\
\hline 3626 & 0.0 & 0.0 & 4.4 & 0.0 & 0.0 & 19.8 & 0.0 & 0.0 & 2.3 & 0.0 & 0.0 & 0.0 \\
\hline 3672 & 128.4 & 250.9 & 172.9 & 39.9 & 18.2 & 844.0 & 0.0 & 2.6 & 2166.7 & 292.6 & 892.5 & 0.0 \\
\hline 3682 & 71.2 & 66.7 & 24.9 & 0.9 & 26.3 & 228.3 & 0.0 & 33.2 & 387.6 & 358.2 & 124.4 & 0.0 \\
\hline 3690 & 5.3 & 9.4 & 37.1 & 4.2 & 0.5 & 137.7 & 0.0 & 0.0 & 22.6 & 7.2 & 0.8 & 0.0 \\
\hline 3780 & 0.0 & 2.0 & 0.7 & 0.0 & 0.4 & 18.3 & 0.0 & 0.0 & 0.0 & 0.0 & 0.0 & 0.0 \\
\hline 3814 & 8.6 & 21.8 & 30.9 & 0.1 & 0.0 & 160.3 & 0.0 & 0.0 & 57.2 & 1.8 & 9.3 & 0.0 \\
\hline 3830 & 46.8 & 44.5 & 52.1 & 0.1 & 0.0 & 106.0 & 0.0 & 0.0 & 178.2 & 2.7 & 17.1 & 0.0 \\
\hline 3884 & 10.8 & 0.0 & 1.5 & 0.0 & 0.0 & 18.7 & 0.0 & 0.0 & 0.0 & 0.0 & 0.0 & 0.0 \\
\hline 3920 & 0.0 & 3.0 & 17.1 & 0.1 & 0.0 & 120.9 & 0.0 & 0.0 & 36.9 & 9.9 & 0.0 & 0.0 \\
\hline 4272 & 0.0 & 0.0 & 6.5 & 2.8 & 0.3 & 60.3 & 0.0 & 0.0 & 8.0 & 27.5 & 0.0 & 0.0 \\
\hline 4316 & 72.4 & 104.4 & 123.3 & 3.7 & 2.1 & 74.3 & 0.0 & 7.6 & 126.3 & 292.5 & 118.9 & 0.0 \\
\hline 4322 & 0.0 & 3.4 & 12.6 & 2.2 & 0.4 & 74.2 & 0.0 & 0.0 & 33.3 & 136.1 & 0.0 & 0.0 \\
\hline 4328 & 118.9 & 100.9 & 190.7 & 59.3 & 0.2 & 1159.5 & 0.0 & 32.8 & 203.6 & 272.3 & 0.0 & 0.0 \\
\hline 4330 & 2.5 & 0.0 & 15.1 & 0.7 & 0.0 & 64.1 & 0.0 & 0.0 & 13.4 & 75.2 & 0.0 & 0.0 \\
\hline 4336 & 117.4 & 117.6 & 169.7 & 18.3 & 4.4 & 482.1 & 171.7 & 3.6 & 220.7 & 376.1 & 2.3 & 0.0 \\
\hline 4388 & 48.1 & 40.9 & 12.6 & 8.3 & 3.7 & 209.3 & 0.0 & 0.0 & 17.6 & 78.6 & 27.2 & 0.0 \\
\hline 4452 & 0.0 & 0.4 & 9.2 & 0.6 & 0.4 & 14.2 & 0.0 & 0.0 & 0.0 & 21.0 & 0.0 & 0.0 \\
\hline 4492 & NA & NA & NA & NA & NA & NA & NA & NA & NA & NA & NA & NA \\
\hline 4606 & 0.9 & 1.8 & 51.7 & 5.4 & 2.8 & 185.6 & 0.0 & 0.0 & 15.6 & 29.8 & 1.0 & 0.0 \\
\hline 4608 & 0.0 & 1.7 & 28.5 & 7.5 & 5.0 & 68.3 & 0.0 & 0.0 & 7.6 & 32.3 & 0.0 & 0.0 \\
\hline
\end{tabular}


Table D2.2: Continued

\begin{tabular}{|c|c|c|c|c|c|c|c|c|c|c|c|c|}
\hline Midas & 13 & 15 & 16 & 19 & 20 & 21 & 22 & 23 & 24 & 25 & 26 & 27 \\
\hline 4610 & 0.0 & 0.0 & 9.5 & 0.2 & 0.0 & 14.6 & 0.0 & 0.0 & 0.0 & 3.0 & 0.0 & 0.0 \\
\hline 4612 & 0.0 & 0.0 & 33.3 & 0.2 & 2.2 & 15.0 & 0.0 & 0.0 & 6.9 & 16.4 & 0.0 & 0.0 \\
\hline 4614 & NA & NA & NA & NA & NA & NA & NA & NA & NA & NA & NA & NA \\
\hline 4618 & 5.3 & 0.0 & 4.3 & 0.3 & 0.0 & 5.1 & 0.0 & 0.0 & 0.0 & 0.2 & 0.0 & 0.0 \\
\hline 4620 & 0.0 & 0.0 & 4.8 & 0.5 & 0.0 & 15.0 & 0.0 & 0.0 & 4.7 & 0.0 & 0.0 & 0.0 \\
\hline 4622 & 24.0 & 0.4 & 62.3 & 10.8 & 0.0 & 377.0 & 0.0 & 0.0 & 25.9 & 59.1 & 0.0 & 0.0 \\
\hline 4624 & 0.2 & 1.4 & 51.8 & 8.6 & 0.0 & 87.9 & 0.0 & 0.0 & 3.7 & 17.2 & 0.0 & 0.0 \\
\hline 4628 & 2.1 & 0.0 & 13.0 & 2.6 & 0.0 & 18.6 & 0.0 & 0.0 & 7.2 & 8.5 & 0.0 & 0.0 \\
\hline 4630 & 13.2 & 0.0 & 27.9 & 7.0 & 0.0 & 104.8 & 0.0 & 0.0 & 3.4 & 43.1 & 0.0 & 0.0 \\
\hline 4766 & 497.8 & 431.6 & 36.6 & 123.0 & 0.0 & 2000.3 & 0.0 & 0.0 & 426.4 & 346.1 & 199.8 & 0.0 \\
\hline 4782 & 87.1 & 7.2 & 1.8 & 5.9 & 0.0 & 376.8 & 0.0 & 0.0 & 9.0 & 0.0 & 101.5 & 0.0 \\
\hline 4788 & 0.0 & 0.0 & 0.8 & 6.3 & 0.0 & 85.7 & 0.0 & 0.0 & 12.0 & 8.3 & 15.5 & 0.0 \\
\hline 4800 & 0.0 & 11.6 & 14.6 & 11.7 & 0.0 & 55.6 & 0.0 & 0.0 & 3.2 & 0.0 & 0.0 & 0.0 \\
\hline 4802 & NA & NA & NA & NA & NA & NA & NA & NA & NA & NA & NA & NA \\
\hline 4806 & 0.0 & 5.3 & 20.2 & 4.2 & 0.0 & 103.1 & 19.9 & 0.0 & 3.8 & 4.2 & 0.0 & 0.0 \\
\hline 4822 & 0.0 & 3.2 & 34.8 & 6.3 & 0.0 & 138.3 & 15.5 & 0.0 & 1.9 & 3.9 & 0.0 & 0.0 \\
\hline 4852 & 50.0 & 55.1 & 126.6 & 33.1 & 0.5 & 514.6 & 7.6 & 0.0 & 35.4 & 6.7 & 8.1 & 0.0 \\
\hline 4857 & 24.9 & 12.9 & 11.2 & 4.7 & 0.0 & 85.7 & 0.0 & 0.0 & 4.1 & 16.4 & 6.8 & 0.0 \\
\hline 4894 & 14.2 & 10.8 & 30.6 & 4.2 & 0.0 & 230.2 & 0.0 & 0.0 & 12.7 & 0.0 & 0.8 & 0.0 \\
\hline 4896 & 493.3 & 127.1 & 134.4 & 13.8 & 0.0 & 484.7 & 84.8 & 1.6 & 105.9 & 47.8 & 64.6 & 0.0 \\
\hline 5024 & 7.7 & 27.1 & 33.9 & 0.6 & 2.8 & 223.6 & 0.0 & 0.0 & 75.0 & 7.0 & 0.0 & 0.0 \\
\hline 5172 & 1451.3 & 475.7 & 573.0 & 47.3 & 8.1 & 1068.5 & 0.0 & 14.3 & 309.7 & 280.5 & 372.4 & 0.0 \\
\hline 5174 & 116.0 & 35.4 & 46.1 & 12.4 & 0.0 & 158.9 & 0.0 & 0.0 & 10.5 & 8.8 & 30.2 & 0.0 \\
\hline 5198 & 24.3 & 3.2 & 10.1 & 0.0 & 0.0 & 39.8 & 0.0 & 1.0 & 11.2 & 0.0 & 0.0 & 0.0 \\
\hline 5222 & 116.3 & 100.4 & 99.4 & 0.2 & 1.6 & 176.5 & 0.0 & 0.0 & 391.5 & 60.1 & 177.7 & 0.0 \\
\hline 5236 & 205.2 & 315.0 & 252.5 & 1.1 & 35.7 & 2215.4 & 0.0 & 0.0 & 535.8 & 56.5 & 89.7 & 0.0 \\
\hline 5240 & 20.8 & 6.6 & 30.0 & 0.0 & 0.0 & 214.1 & 0.0 & 0.0 & 74.7 & 13.2 & 1.3 & 0.0 \\
\hline 5280 & 888.4 & 382.5 & 217.1 & 24.4 & 62.0 & 1636.7 & 0.0 & 4.2 & 803.5 & 92.3 & 112.9 & 0.0 \\
\hline 5344 & 237.9 & 176.9 & 91.0 & 13.3 & 28.1 & 1019.2 & 0.0 & 0.0 & 189.3 & 37.0 & 136.0 & 0.0 \\
\hline 5348 & 31.5 & 8.5 & 23.8 & 2.9 & 0.4 & 180.0 & 0.0 & 0.0 & 42.9 & 48.0 & 16.1 & 0.0 \\
\hline 5349 & 13.0 & 38.6 & 27.9 & 13.2 & 0.3 & 689.2 & 0.0 & 0.0 & 33.2 & 0.0 & 0.6 & 0.0 \\
\hline 5352 & 8.9 & 3.0 & 18.5 & 3.5 & 0.2 & 287.0 & 0.0 & 0.0 & 7.9 & 4.1 & 0.0 & 0.0 \\
\hline 5386 & 60.1 & 133.4 & 58.2 & 23.6 & 11.5 & 150.4 & 0.0 & 0.0 & 27.8 & 5.3 & 0.8 & 0.0 \\
\hline 5400 & 310.9 & 175.1 & 350.7 & 62.5 & 62.1 & 1841.2 & 95.2 & 0.0 & 103.7 & 49.4 & 64.5 & 0.0 \\
\hline 5408 & 18.6 & 37.4 & 54.8 & 19.2 & 0.9 & 484.2 & 0.0 & 0.0 & 24.5 & 0.0 & 0.2 & 0.0 \\
\hline 5416 & 150.1 & 102.3 & 76.6 & 15.6 & 1.7 & 466.5 & 0.0 & 0.0 & 47.2 & 20.3 & 36.9 & 0.0 \\
\hline 5448 & 424.0 & 257.5 & 268.9 & 44.5 & 9.7 & 1578.2 & 0.0 & 0.0 & 65.1 & 52.7 & 49.6 & 0.0 \\
\hline 5458 & 260.9 & 100.6 & 87.0 & 2.7 & 0.0 & 208.5 & 0.0 & 0.0 & 72.8 & 13.1 & 52.4 & 0.0 \\
\hline 5490 & 14.4 & 2.6 & 1.8 & 2.4 & 0.0 & 63.8 & 0.0 & 0.0 & 0.0 & 4.9 & 0.0 & 0.0 \\
\hline 5682 & 719.5 & 184.5 & 212.7 & 30.1 & 30.4 & 248.9 & 410.4 & 0.0 & 58.5 & 24.7 & 136.6 & 0.0 \\
\hline 5690 & 57.2 & 36.9 & 40.1 & 22.4 & 0.0 & 129.9 & 0.0 & 0.0 & 4.0 & 0.2 & 0.0 & 0.0 \\
\hline
\end{tabular}


Table D2.2: Continued

\begin{tabular}{|c|c|c|c|c|c|c|c|c|c|c|c|c|}
\hline Midas & 13 & 15 & 16 & 19 & 20 & 21 & 22 & 23 & 24 & 25 & 26 & 27 \\
\hline 5710 & 25.4 & 10.9 & 37.7 & 11.9 & 0.0 & 144.4 & 0.0 & 0.0 & 21.3 & 5.4 & 0.0 & 0.0 \\
\hline 5780 & 189.6 & 360.9 & 485.7 & 1.2 & 2.0 & 2120.9 & 16.7 & 13.6 & 1714.9 & 1311.5 & 285.1 & 0.0 \\
\hline 5814 & 40.7 & 7.3 & 26.3 & 5.4 & 0.0 & 447.7 & 0.0 & 0.0 & 114.2 & 0.8 & 27.1 & 0.0 \\
\hline 9685 & 16.1 & 25.7 & 8.6 & 0.8 & 0.4 & 291.6 & 0.0 & 0.0 & 34.5 & 4.0 & 0.0 & 0.0 \\
\hline 9931 & 3.3 & 23.0 & 30.1 & 0.0 & 0.0 & 268.1 & 0.0 & 0.0 & 170.6 & 17.0 & 131.3 & 0.0 \\
\hline \multicolumn{13}{|l|}{ LEA } \\
\hline 5780 & 189.6 & 360.9 & 485.7 & 1.2 & 2.0 & 2120.9 & 16.7 & 13.6 & 1714.9 & 1311.5 & 285.1 & 0.0 \\
\hline 3418 & 25.1 & 12.8 & 36.5 & 0.0 & 0.0 & 176.7 & 0.0 & 0.0 & 187.6 & 34.9 & 10.9 & 0.0 \\
\hline 5780 & 189.6 & 360.9 & 485.7 & 1.2 & 2.0 & 2120.9 & 16.7 & 13.6 & 1714.9 & 1311.5 & 285.1 & 0.0 \\
\hline 3130 & 1.0 & 6.1 & 10.2 & 0.0 & 0.0 & 94.2 & 0.0 & 0.0 & 129.1 & 78.1 & 14.6 & 0.0 \\
\hline 3382 & 1.4 & 6.6 & 0.0 & 0.2 & 0.0 & 126.4 & 0.0 & 0.0 & 8.3 & 1.6 & 17.4 & 0.0 \\
\hline 3424 & 1.2 & 7.7 & 21.8 & 0.0 & 0.0 & 75.5 & 0.0 & 0.0 & 61.2 & 12.7 & 9.8 & 0.0 \\
\hline 3199 & 5.5 & 17.6 & 10.1 & 0.0 & 0.0 & 69.9 & 0.0 & 0.0 & 122.2 & 1.5 & 86.1 & 0.0 \\
\hline 3134 & 42.3 & 117.9 & 119.1 & 0.1 & 0.0 & 630.5 & 0.0 & 0.0 & 974.0 & 589.7 & 56.1 & 0.0 \\
\hline 3416 & 0.2 & 0.8 & 54.2 & 0.1 & 0.0 & 183.8 & 0.0 & 0.0 & 270.7 & 14.9 & 23.4 & 0.0 \\
\hline 9685 & 16.1 & 25.7 & 8.6 & 0.8 & 0.4 & 291.6 & 0.0 & 0.0 & 34.5 & 4.0 & 0.0 & 0.0 \\
\hline 3420 & 9.5 & 9.5 & 20.9 & 0.1 & 0.0 & 94.7 & 0.0 & 0.0 & 39.5 & 36.0 & 5.5 & 0.0 \\
\hline 3454 & 1.8 & 44.8 & 86.2 & 0.0 & 0.0 & 532.7 & 0.0 & 0.0 & 177.2 & 89.7 & 44.5 & 0.0 \\
\hline 5582 & 2.0 & 9.3 & 24.6 & 0.0 & 0.0 & 27.4 & 0.0 & 0.0 & 109.4 & 53.2 & 33.8 & 0.0 \\
\hline 3134 & 42.3 & 117.9 & 119.1 & 0.1 & 0.0 & 630.5 & 0.0 & 0.0 & 974.0 & 589.7 & 56.1 & 0.0 \\
\hline 5780 & 189.6 & 360.9 & 485.7 & 1.2 & 2.0 & 2120.9 & 16.7 & 13.6 & 1714.9 & 1311.5 & 285.1 & 0.0 \\
\hline 5780 & 189.6 & 360.9 & 485.7 & 1.2 & 2.0 & 2120.9 & 16.7 & 13.6 & 1714.9 & 1311.5 & 285.1 & 0.0 \\
\hline 3132 & 26.1 & 29.2 & 15.9 & 0.0 & 0.0 & 311.9 & 0.0 & 0.0 & 192.7 & 125.6 & 46.4 & 0.0 \\
\hline 3126 & 0.0 & 8.3 & 10.7 & 0.0 & 0.0 & 51.8 & 0.0 & 0.0 & 57.4 & 39.4 & 1.2 & 0.0 \\
\hline 3234 & 27.1 & 37.1 & 19.2 & 0.0 & 0.0 & 99.4 & 0.0 & 0.0 & 68.5 & 11.1 & 3.9 & 0.0 \\
\hline 3374 & 25.0 & 21.6 & 19.8 & 0.0 & 0.0 & 296.5 & 0.0 & 0.2 & 167.2 & 14.3 & 38.5 & 0.0 \\
\hline 3134 & 42.3 & 117.9 & 119.1 & 0.1 & 0.0 & 630.5 & 0.0 & 0.0 & 974.0 & 589.7 & 56.1 & 0.0 \\
\hline 3452 & 23.6 & 21.5 & 81.2 & 0.4 & 0.0 & 172.2 & 0.0 & 13.2 & 349.6 & 155.3 & 52.2 & 0.0 \\
\hline 3454 & 1.8 & 44.8 & 86.2 & 0.0 & 0.0 & 532.7 & 0.0 & 0.0 & 177.2 & 89.7 & 44.5 & 0.0 \\
\hline 3448 & 5.5 & 7.3 & 13.3 & 0.0 & 0.0 & 43.1 & 0.0 & 0.0 & 128.8 & 26.6 & 10.0 & 0.0 \\
\hline 3232 & 1.1 & 2.5 & 16.6 & 0.0 & 0.0 & 76.6 & 0.0 & 0.0 & 155.0 & 29.9 & 46.9 & 0.0 \\
\hline 3456 & 26.3 & 36.4 & 40.2 & 0.3 & 0.7 & 185.7 & 0.0 & 0.5 & 217.0 & 378.6 & 5.5 & 0.0 \\
\hline 5780 & 189.6 & 360.9 & 485.7 & 1.2 & 2.0 & 2120.9 & 16.7 & 13.6 & 1714.9 & 1311.5 & 285.1 & 0.0 \\
\hline
\end{tabular}


Table D3.1: Adjacent Land cover Area (ha.) from type 2-12. Adjacent land cover area data from 2004, with identification code in Table D1, with types 2-12.

\begin{tabular}{|c|c|c|c|c|c|c|c|c|c|c|c|}
\hline Midas & 2 & 3 & 4 & 5 & 6 & 7 & 8 & 9 & 10 & 11 & 12 \\
\hline \multicolumn{12}{|l|}{2015} \\
\hline 78 & 10.6 & 4.5 & 19.6 & 0.0 & 0.5 & 0.0 & 0.0 & 292.4 & 66.0 & 199.4 & 0.8 \\
\hline 177 & 0.9 & 4.1 & 0.0 & 0.0 & 28.5 & 2.5 & 0.0 & 153.3 & 313.5 & 709.0 & 3.1 \\
\hline 224 & 0.2 & 0.0 & 0.5 & 0.0 & 0.0 & 0.0 & 0.0 & 9.5 & 125.6 & 93.2 & 0.0 \\
\hline 3444 & 4.6 & 8.4 & 25.7 & 4.6 & 21.2 & 213.1 & 7.5 & 931.3 & 521.3 & 1468.4 & 7.5 \\
\hline 3446 & 0.4 & 5.0 & 13.2 & 0.0 & 4.1 & 18.4 & 0.9 & 88.7 & 137.8 & 454.4 & 10.5 \\
\hline 3748 & 11.9 & 11.8 & 9.1 & 27.8 & 5.3 & 144.0 & 0.8 & 151.1 & 181.7 & 181.8 & 11.6 \\
\hline 3750 & 1.1 & 3.9 & 29.1 & 4.7 & 1.1 & 13.7 & 0.0 & 100.0 & 59.9 & 134.2 & 2.2 \\
\hline 3796 & 1.5 & 7.8 & 16.5 & 0.7 & 22.0 & 228.3 & 0.2 & 136.0 & 33.6 & 168.2 & 11.7 \\
\hline 3838 & 4.2 & 2.1 & 6.3 & 2.4 & 7.7 & 11.2 & 0.0 & 13.4 & 406.7 & 206.2 & 12.7 \\
\hline 3916 & 1.0 & 0.4 & 0.3 & 0.0 & 6.0 & 0.2 & 0.0 & 48.7 & 89.4 & 188.3 & 3.2 \\
\hline 4434 & 0.0 & 0.0 & 0.0 & 0.0 & 0.1 & 0.0 & 0.0 & 21.2 & 790.9 & 282.4 & 13.9 \\
\hline 4538 & 0.0 & 0.0 & 0.0 & 0.0 & 0.0 & 0.0 & 0.3 & 143.5 & 181.1 & 23.1 & 0.0 \\
\hline 5172 & 3.3 & 6.1 & 18.0 & 6.5 & 19.0 & 49.3 & 0.0 & 131.7 & 128.2 & 307.2 & 0.2 \\
\hline 5190 & 0.1 & 0.0 & 7.1 & 0.0 & 0.0 & 2.8 & 0.0 & 351.9 & 62.3 & 135.7 & 0.0 \\
\hline 5272 & 11.2 & 8.4 & 23.7 & 0.0 & 1.7 & 11.4 & 0.0 & 306.5 & 468.8 & 626.2 & 1.1 \\
\hline 5274 & 15.4 & 9.2 & 36.2 & 4.2 & 35.2 & 70.7 & 0.4 & 502.8 & 487.1 & 1349.9 & 1.2 \\
\hline 5280 & 19.8 & 16.7 & 83.7 & 0.0 & 58.6 & 50.6 & 0.0 & 242.4 & 130.8 & 563.4 & 4.6 \\
\hline 5344 & 4.9 & 4.3 & 21.7 & 0.0 & 22.3 & 45.7 & 0.0 & 243.8 & 80.5 & 483.2 & 0.6 \\
\hline 5348 & 1.5 & 6.9 & 15.5 & 1.7 & 6.1 & 0.0 & 0.0 & 113.7 & 16.4 & 137.7 & 1.3 \\
\hline 5349 & 3.6 & 2.9 & 6.8 & 0.0 & 3.4 & 3.4 & 0.0 & 49.7 & 155.6 & 298.8 & 1.9 \\
\hline 5352 & 7.0 & 9.2 & 14.2 & 0.0 & 18.9 & 0.0 & 0.0 & 82.5 & 35.9 & 228.0 & 0.2 \\
\hline 5400 & 7.0 & 9.8 & 18.7 & 1.0 & 26.5 & 397.4 & 1.0 & 641.5 & 581.2 & 773.5 & 8.9 \\
\hline 5408 & 1.3 & 2.6 & 18.2 & 3.0 & 28.1 & 99.4 & 0.0 & 341.2 & 18.8 & 251.1 & 7.2 \\
\hline 5448 & 10.1 & 24.6 & 69.4 & 15.8 & 53.8 & 378.7 & 0.6 & 487.4 & 292.2 & 448.4 & 4.7 \\
\hline \multicolumn{12}{|l|}{ DEP } \\
\hline 70 & 3.0 & 4.0 & 20.0 & 0.1 & 40.2 & 41.6 & 1.6 & 94.8 & 166.7 & 203.9 & 0.0 \\
\hline 80 & NA & NA & NA & $\mathrm{NA}$ & NA & NA & NA & NA & NA & NA & NA \\
\hline 121 & NA & NA & NA & NA & NA & NA & NA & NA & NA & NA & NA \\
\hline 177 & 0.9 & 4.1 & 0.0 & 0.0 & 28.5 & 2.5 & 0.0 & 153.3 & 313.5 & 709.0 & 3.1 \\
\hline 243 & 0.0 & 0.0 & 0.0 & 0.0 & 0.0 & 0.0 & 0.0 & 27.1 & 257.3 & 591.5 & 137.6 \\
\hline 262 & 0.0 & 0.4 & 1.2 & 0.0 & 0.0 & 0.0 & 0.0 & 109.7 & 32.7 & 115.7 & 0.1 \\
\hline 342 & 0.0 & 0.0 & 0.0 & 1.1 & 0.0 & 0.0 & 0.0 & 41.0 & 225.0 & 431.8 & 8.4 \\
\hline 386 & 0.0 & 0.0 & 0.0 & 0.0 & 0.0 & 0.0 & 0.0 & 19.5 & 0.0 & 77.5 & 6.9 \\
\hline 410 & 0.0 & 0.0 & 0.0 & 0.0 & 0.0 & 0.0 & 0.0 & 155.0 & 125.9 & 335.4 & 22.1 \\
\hline 447 & 0.0 & 0.0 & 0.6 & 0.0 & 0.0 & 0.0 & 1.2 & 0.0 & 9.6 & 11.3 & 5.6 \\
\hline 760 & 0.0 & 0.0 & 0.1 & 0.0 & 10.1 & 0.1 & 0.0 & 86.0 & 32.0 & 157.9 & 0.0 \\
\hline 954 & 0.0 & 0.0 & 0.0 & 0.0 & 0.0 & 0.0 & 0.0 & 494.4 & 1621.2 & 1146.3 & 179.4 \\
\hline 1068 & 0.7 & 0.0 & 0.0 & 0.0 & 2.1 & 2.9 & 0.0 & 94.6 & 111.0 & 140.9 & 1.1 \\
\hline
\end{tabular}


Table D3.1: Continued

\begin{tabular}{|c|c|c|c|c|c|c|c|c|c|c|c|}
\hline Midas & 2 & 3 & 4 & 5 & 6 & 7 & 8 & 9 & 10 & 11 & 12 \\
\hline 1070 & NA & NA & NA & NA & NA & NA & NA & NA & NA & NA & NA \\
\hline 1078 & 0.0 & 0.0 & 0.0 & 0.0 & 0.0 & 0.0 & 0.0 & 25.7 & 2401.2 & 920.5 & 2.9 \\
\hline 1088 & 0.0 & 0.7 & 0.6 & 0.0 & 0.0 & 0.0 & 0.0 & 235.4 & 211.8 & 437.4 & 0.0 \\
\hline 1150 & 0.0 & 0.0 & 0.0 & 0.0 & 0.0 & 0.0 & 0.0 & 0.0 & 0.0 & 0.0 & 0.0 \\
\hline 1210 & 0.0 & 0.5 & 0.0 & 0.0 & 0.0 & 0.0 & 0.0 & 54.7 & 523.1 & 348.7 & 5.3 \\
\hline 2004 & 0.0 & 1.2 & 0.8 & 0.0 & 0.0 & 0.0 & 0.0 & 200.3 & 189.9 & 97.3 & 20.9 \\
\hline 2020 & 0.0 & 0.5 & 0.0 & 0.0 & 0.0 & 0.0 & 1.7 & 543.9 & 2226.0 & 603.5 & 151.4 \\
\hline 2146 & 4.6 & 2.5 & 10.5 & 2.2 & 4.3 & 7.8 & 0.0 & 567.3 & 388.0 & 705.1 & 6.2 \\
\hline 2156 & 0.0 & 0.9 & 3.9 & 6.5 & 28.2 & 0.0 & 0.0 & 8.8 & 25.3 & 47.4 & 0.1 \\
\hline 2242 & 0.0 & 0.0 & 0.0 & 0.0 & 0.0 & 14.6 & 0.0 & 58.5 & 40.1 & 250.8 & 5.7 \\
\hline 2286 & 0.1 & 0.6 & 1.3 & 0.1 & 0.8 & 42.8 & 0.0 & 29.0 & 0.9 & 17.8 & 2.0 \\
\hline 2590 & 0.2 & 0.4 & 0.0 & 0.0 & 70.9 & 17.1 & 0.0 & 677.1 & 171.4 & 811.0 & 4.4 \\
\hline 2608 & 0.0 & 0.4 & 0.0 & 0.0 & 0.1 & 0.0 & 0.0 & 333.3 & 3.2 & 151.6 & 0.0 \\
\hline 2948 & 0.0 & 0.0 & 0.0 & 0.0 & 0.0 & 0.0 & 0.0 & 380.3 & 941.7 & 951.1 & 18.5 \\
\hline 3038 & 0.0 & 0.0 & 0.0 & 0.0 & 7.0 & 2.1 & 0.0 & 182.0 & 134.0 & 439.9 & 4.4 \\
\hline 3376 & 0.0 & 0.0 & 0.0 & 0.0 & 0.0 & 0.0 & 0.0 & 0.3 & 37.7 & 43.7 & 0.0 \\
\hline 3388 & 0.3 & 0.2 & 0.7 & 0.0 & 0.0 & 9.8 & 0.0 & 18.1 & 15.1 & 40.6 & 0.0 \\
\hline 3434 & 2.0 & 3.8 & 6.3 & 0.0 & 4.2 & 65.6 & 0.0 & 20.7 & 194.0 & 450.0 & 0.2 \\
\hline 3452 & 0.4 & 3.6 & 18.4 & 3.4 & 9.5 & 20.6 & 0.0 & 7.4 & 61.5 & 152.5 & 4.8 \\
\hline 3454 & 0.7 & 28.9 & 4.7 & 0.5 & 2.7 & 42.3 & 0.0 & 142.3 & 125.8 & 353.4 & 11.3 \\
\hline 3604 & 0.0 & 1.5 & 0.3 & 0.2 & 14.1 & 45.8 & 0.2 & 65.1 & 143.1 & 215.2 & 11.2 \\
\hline 3626 & 0.2 & 0.1 & 0.0 & 0.1 & 0.0 & 0.0 & 0.0 & 0.7 & 3.8 & 23.1 & 0.8 \\
\hline 3672 & 2.4 & 4.2 & 4.8 & 85.0 & 72.0 & 19.6 & 14.2 & 284.0 & 932.0 & 560.2 & 3.1 \\
\hline 3682 & 4.5 & 4.5 & 30.2 & 7.6 & 12.1 & 27.4 & 0.0 & 111.4 & 24.2 & 145.9 & 2.2 \\
\hline 3690 & 0.0 & 0.0 & 4.3 & 0.0 & 0.1 & 0.5 & 0.0 & 61.4 & 65.6 & 238.9 & 0.9 \\
\hline 3780 & 0.0 & 0.0 & 0.0 & 0.0 & 0.9 & 0.0 & 0.0 & 28.9 & 2.5 & 2.8 & 0.0 \\
\hline 3814 & 0.2 & 2.3 & 3.7 & 0.0 & 4.0 & 72.1 & 0.0 & 99.1 & 43.1 & 139.0 & 0.0 \\
\hline 3830 & 0.8 & 0.4 & 0.2 & 0.0 & 1.7 & 8.1 & 0.0 & 49.2 & 76.4 & 215.7 & 1.2 \\
\hline 3884 & 0.3 & 0.0 & 0.1 & 0.5 & 0.0 & 8.3 & 0.0 & 0.0 & 0.3 & 36.8 & 0.1 \\
\hline 3920 & 0.0 & 0.0 & 0.0 & 0.1 & 1.9 & 8.6 & 0.0 & 4.8 & 33.1 & 77.8 & 0.0 \\
\hline 4272 & 0.0 & 1.1 & 0.0 & 0.0 & 1.6 & 0.0 & 0.0 & 53.2 & 29.3 & 14.6 & 0.0 \\
\hline 4316 & 3.3 & 0.0 & 1.6 & 0.0 & 0.0 & 2.3 & 0.0 & 103.9 & 92.3 & 151.2 & 6.2 \\
\hline 4322 & 0.9 & 0.3 & 3.3 & 0.0 & 1.6 & 0.0 & 0.0 & 84.1 & 12.4 & 19.9 & 0.0 \\
\hline 4328 & 1.3 & 1.3 & 6.4 & 0.2 & 18.3 & 7.3 & 0.0 & 801.8 & 1032.8 & 302.3 & 3.2 \\
\hline 4330 & 0.0 & 0.8 & 0.0 & 0.0 & 2.4 & 0.0 & 0.0 & 152.4 & 13.9 & 23.3 & 0.0 \\
\hline 4336 & 1.0 & 4.9 & 8.4 & 3.1 & 5.5 & 24.3 & 0.8 & 163.8 & 176.1 & 353.3 & 9.2 \\
\hline 4388 & 0.0 & 0.9 & 0.0 & 0.0 & 12.8 & 0.0 & 0.0 & 23.1 & 132.8 & 261.7 & 13.8 \\
\hline 4452 & 0.0 & 0.0 & 0.0 & 0.0 & 0.0 & 0.0 & 0.0 & 0.0 & 50.3 & 50.5 & 0.0 \\
\hline 4492 & NA & NA & NA & NA & NA & NA & NA & NA & NA & NA & NA \\
\hline 4606 & 0.0 & 0.6 & 0.4 & 0.0 & 0.0 & 0.0 & 0.5 & 0.0 & 81.7 & 124.4 & 3.0 \\
\hline 4608 & 0.8 & 0.5 & 0.4 & 0.0 & 0.0 & 0.0 & 0.0 & 0.0 & 52.9 & 81.1 & 0.1 \\
\hline
\end{tabular}


Table D3.1: Continued

\begin{tabular}{|c|c|c|c|c|c|c|c|c|c|c|c|}
\hline Midas & 2 & 3 & 4 & 5 & 6 & 7 & 8 & 9 & 10 & 11 & 12 \\
\hline 4610 & 0.0 & 0.0 & 0.0 & 0.0 & 0.0 & 0.0 & 0.0 & 0.0 & 31.3 & 0.0 & 0.3 \\
\hline 4612 & 0.4 & 0.2 & 0.0 & 0.0 & 0.0 & 0.0 & 0.0 & 0.0 & 19.9 & 4.5 & 2.3 \\
\hline 4614 & NA & NA & NA & NA & NA & NA & NA & NA & NA & NA & NA \\
\hline 4618 & 0.0 & 0.0 & 0.1 & 0.0 & 0.0 & 0.0 & 0.5 & 0.0 & 14.1 & 0.1 & 0.0 \\
\hline 4620 & NA & NA & NA & NA & NA & NA & NA & NA & NA & NA & NA \\
\hline 4622 & 0.3 & 1.2 & 3.3 & 0.0 & 0.0 & 0.0 & 3.4 & 31.8 & 576.7 & 202.1 & 0.3 \\
\hline 4624 & 0.0 & 1.8 & 1.8 & 0.0 & 0.0 & 0.0 & 0.3 & 0.0 & 107.9 & 116.8 & 7.7 \\
\hline 4628 & 0.0 & 1.0 & 4.5 & 3.4 & 0.0 & 0.0 & 3.2 & 0.0 & 57.2 & 17.1 & 1.3 \\
\hline 4630 & 5.1 & 3.0 & 4.2 & 0.0 & 0.0 & 0.0 & 4.7 & 0.0 & 172.3 & 148.9 & 0.0 \\
\hline 4766 & 0.0 & 0.0 & 0.0 & 0.0 & 0.0 & 0.0 & 4.5 & 39.3 & 1922.5 & 914.8 & 8.7 \\
\hline 4782 & 0.0 & 0.0 & 0.0 & 0.0 & 0.0 & 0.0 & 0.0 & 41.7 & 510.3 & 486.9 & 0.0 \\
\hline 4788 & 0.0 & 0.0 & 0.0 & 0.0 & 0.0 & 0.0 & 0.0 & 0.5 & 53.5 & 28.7 & 0.1 \\
\hline 4800 & 0.9 & 0.2 & 4.1 & 0.0 & 0.0 & 14.6 & 0.0 & 100.2 & 1.8 & 3.2 & 0.0 \\
\hline 4802 & NA & NA & NA & NA & NA & NA & NA & NA & NA & NA & NA \\
\hline 4806 & 0.0 & 0.7 & 3.1 & 0.0 & 0.0 & 64.4 & 0.0 & 338.7 & 27.7 & 28.0 & 5.0 \\
\hline 4822 & 9.4 & 9.6 & 36.0 & 6.8 & 2.7 & 43.0 & 0.0 & 168.2 & 1.1 & 50.1 & 1.0 \\
\hline 4852 & 0.3 & 2.7 & 7.6 & 0.0 & 0.0 & 105.8 & 0.4 & 840.1 & 222.4 & 242.4 & 16.8 \\
\hline 4857 & 0.5 & 0.0 & 0.0 & 0.0 & 0.0 & 10.2 & 0.0 & 87.2 & 8.1 & 37.8 & 0.4 \\
\hline 4894 & 0.0 & 3.3 & 3.1 & 4.1 & 7.4 & 6.0 & 0.0 & 50.3 & 47.5 & 228.7 & 0.0 \\
\hline 4896 & 0.2 & 2.0 & 9.5 & 2.5 & 2.8 & 24.4 & 0.0 & 218.0 & 124.3 & 335.9 & 0.0 \\
\hline 5024 & 3.7 & 1.6 & 26.3 & 0.0 & 2.3 & 25.9 & 0.0 & 28.3 & 79.8 & 291.8 & 42.5 \\
\hline 5172 & 3.3 & 6.1 & 18.0 & 6.5 & 19.0 & 49.3 & 0.0 & 131.7 & 128.2 & 307.2 & 0.2 \\
\hline 5174 & 0.0 & 1.0 & 3.5 & 0.0 & 0.9 & 14.3 & 0.0 & 194.3 & 15.1 & 169.1 & 0.8 \\
\hline 5198 & 0.0 & 0.0 & 0.1 & 0.0 & 0.0 & 1.9 & 0.0 & 65.1 & 20.1 & 20.4 & 0.0 \\
\hline 5222 & 0.3 & 1.7 & 1.9 & 2.5 & 0.0 & 71.2 & 0.0 & 75.6 & 35.0 & 224.1 & 1.8 \\
\hline 5236 & 5.7 & 22.5 & 44.2 & 126.1 & 52.2 & 370.9 & 0.0 & 462.8 & 526.5 & 1083.4 & 10.7 \\
\hline 5240 & 0.0 & 0.8 & 7.0 & 0.0 & 0.9 & 26.3 & 0.0 & 48.6 & 96.7 & 88.8 & 7.6 \\
\hline 5280 & 19.8 & 16.7 & 83.7 & 0.0 & 58.6 & 50.6 & 0.0 & 242.4 & 130.8 & 563.4 & 4.6 \\
\hline 5344 & 4.9 & 4.3 & 21.7 & 0.0 & 22.3 & 45.7 & 0.0 & 243.8 & 80.5 & 483.2 & 0.6 \\
\hline 5348 & 1.5 & 6.9 & 15.5 & 1.7 & 6.1 & 0.0 & 0.0 & 113.7 & 16.4 & 137.7 & 1.3 \\
\hline 5349 & 3.6 & 2.9 & 6.8 & 0.0 & 3.4 & 3.4 & 0.0 & 49.7 & 155.6 & 298.8 & 1.9 \\
\hline 5352 & 7.0 & 9.2 & 14.2 & 0.0 & 18.9 & 0.0 & 0.0 & 82.5 & 35.9 & 228.0 & 0.2 \\
\hline 5386 & 0.2 & 1.9 & 3.2 & 0.0 & 7.3 & 22.0 & 0.0 & 185.6 & 29.7 & 321.3 & 0.0 \\
\hline 5400 & 7.0 & 9.8 & 18.7 & 1.0 & 26.5 & 397.4 & 1.0 & 641.5 & 581.2 & 773.5 & 8.9 \\
\hline 5408 & 1.3 & 2.6 & 18.2 & 3.0 & 28.1 & 99.4 & 0.0 & 341.2 & 18.8 & 251.1 & 7.2 \\
\hline 5416 & 2.8 & 2.7 & 19.4 & 5.9 & 3.2 & 6.8 & 0.0 & 262.1 & 32.2 & 389.2 & 1.1 \\
\hline 5448 & 10.1 & 24.6 & 69.4 & 15.8 & 53.8 & 378.7 & 0.6 & 487.4 & 292.2 & 448.4 & 4.7 \\
\hline 5458 & 1.2 & 2.7 & 9.5 & 0.0 & 7.1 & 25.7 & 1.0 & 147.0 & 63.1 & 206.5 & 1.5 \\
\hline 5490 & NA & NA & NA & NA & NA & NA & NA & NA & NA & NA & NA \\
\hline 5682 & 0.7 & 1.1 & 8.3 & 0.0 & 0.0 & 161.4 & 0.0 & 69.1 & 8.1 & 57.0 & 4.8 \\
\hline 5690 & 1.6 & 1.5 & 9.1 & 0.1 & 41.2 & 77.9 & 0.2 & 26.2 & 40.7 & 35.0 & 4.1 \\
\hline
\end{tabular}


Table D3.1: Continued

\begin{tabular}{|c|c|c|c|c|c|c|c|c|c|c|c|}
\hline Midas & 2 & 3 & 4 & 5 & 6 & 7 & 8 & 9 & 10 & 11 & 12 \\
\hline 5710 & 0.6 & 0.9 & 2.3 & 0.0 & 4.2 & 4.9 & 0.0 & 110.4 & 16.5 & 128.2 & 0.0 \\
\hline 5780 & 26.2 & 37.7 & 108.6 & 21.0 & 46.4 & 143.0 & 0.7 & 734.4 & 455.2 & 1758.7 & 7.7 \\
\hline 5814 & 4.5 & 6.7 & 9.0 & 0.0 & 5.1 & 8.7 & 0.0 & 257.9 & 197.6 & 388.1 & 0.2 \\
\hline 9685 & 15.4 & 17.1 & 52.5 & 77.9 & 13.7 & 4.1 & 0.0 & 60.9 & 71.3 & 142.8 & 0.0 \\
\hline 9931 & 3.0 & 0.6 & 9.1 & 3.5 & 7.3 & 0.0 & 0.2 & 156.2 & 3.3 & 87.7 & 0.9 \\
\hline \multicolumn{12}{|l|}{ LEA } \\
\hline 5780 & 26.2 & 37.7 & 108.6 & 21.0 & 46.4 & 143.0 & 0.7 & 734.4 & 455.2 & 1758.7 & 7.7 \\
\hline 3418 & 0.6 & 1.0 & 0.0 & 0.0 & 0.7 & 55.1 & 0.0 & 13.7 & 111.6 & 86.3 & 1.1 \\
\hline 5780 & 26.2 & 37.7 & 108.6 & 21.0 & 46.4 & 143.0 & 0.7 & 734.4 & 455.2 & 1758.7 & 7.7 \\
\hline 3130 & 0.5 & 0.3 & 0.0 & 0.0 & 0.9 & 9.8 & 0.0 & 25.5 & 81.4 & 66.4 & 0.0 \\
\hline 3382 & NA & NA & NA & NA & NA & NA & NA & NA & NA & NA & NA \\
\hline 3424 & 0.2 & 0.0 & 0.0 & 0.0 & 0.7 & 16.3 & 0.0 & 70.4 & 35.4 & 293.0 & 0.0 \\
\hline 3199 & 0.0 & 0.0 & 0.0 & 0.0 & 3.2 & 0.0 & 0.0 & 158.0 & 10.6 & 89.9 & 0.0 \\
\hline 3134 & 0.9 & 5.8 & 7.4 & 4.5 & 30.3 & 84.4 & 33.5 & 572.3 & 267.5 & 1089.4 & 10.3 \\
\hline 3416 & 3.7 & 2.3 & 7.1 & 0.0 & 1.9 & 63.4 & 0.0 & 27.2 & 141.9 & 266.4 & 0.0 \\
\hline 9685 & 15.4 & 17.1 & 52.5 & 77.9 & 13.7 & 4.1 & 0.0 & 60.9 & 71.3 & 142.8 & 0.0 \\
\hline 3420 & 0.0 & 0.4 & 0.4 & 0.0 & 0.3 & 16.6 & 0.0 & 34.5 & 19.8 & 53.5 & 0.0 \\
\hline 3454 & 0.7 & 28.9 & 4.7 & 0.5 & 2.7 & 42.3 & 0.0 & 142.3 & 125.8 & 353.4 & 11.3 \\
\hline 5582 & 0.0 & 2.4 & 2.8 & 0.3 & 0.5 & 9.5 & 0.0 & 0.0 & 9.9 & 35.0 & 10.4 \\
\hline 3134 & 0.9 & 5.8 & 7.4 & 4.5 & 30.3 & 84.4 & 33.5 & 572.3 & 267.5 & 1089.4 & 10.3 \\
\hline 5780 & 26.2 & 37.7 & 108.6 & 21.0 & 46.4 & 143.0 & 0.7 & 734.4 & 455.2 & 1758.7 & 7.7 \\
\hline 5780 & 26.2 & 37.7 & 108.6 & 21.0 & 46.4 & 143.0 & 0.7 & 734.4 & 455.2 & 1758.7 & 7.7 \\
\hline 3132 & 0.0 & 0.0 & 0.3 & 0.0 & 0.0 & 0.0 & 0.0 & 70.4 & 37.5 & 191.0 & 0.0 \\
\hline 3126 & 0.0 & 0.8 & 0.0 & 0.0 & 0.0 & 6.5 & 0.0 & 0.3 & 32.0 & 124.4 & 0.0 \\
\hline 3234 & 0.0 & 0.0 & 0.0 & 0.0 & 0.0 & 4.8 & 0.0 & 100.6 & 16.1 & 131.9 & 0.0 \\
\hline 3374 & 0.7 & 0.9 & 4.8 & 0.0 & 1.8 & 0.0 & 0.0 & 285.1 & 34.4 & 233.3 & 0.5 \\
\hline 3134 & 0.9 & 5.8 & 7.4 & 4.5 & 30.3 & 84.4 & 33.5 & 572.3 & 267.5 & 1089.4 & 10.3 \\
\hline 3452 & 0.4 & 3.6 & 18.4 & 3.4 & 9.5 & 20.6 & 0.0 & 7.4 & 61.5 & 152.5 & 4.8 \\
\hline 3454 & 0.7 & 28.9 & 4.7 & 0.5 & 2.7 & 42.3 & 0.0 & 142.3 & 125.8 & 353.4 & 11.3 \\
\hline 3448 & 0.0 & 0.2 & 0.6 & 0.0 & 4.2 & 21.7 & 0.0 & 6.9 & 105.9 & 110.0 & 12.2 \\
\hline 3232 & 0.0 & 0.5 & 1.5 & 0.0 & 1.8 & 11.8 & 0.0 & 35.3 & 29.3 & 70.2 & 0.0 \\
\hline 3456 & 0.0 & 0.5 & 0.8 & 0.0 & 0.0 & 7.2 & 0.3 & 9.9 & 38.6 & 137.7 & 1.3 \\
\hline 5780 & 26.2 & 37.7 & 108.6 & 21.0 & 46.4 & 143.0 & 0.7 & 734.4 & 455.2 & 1758.7 & 7.7 \\
\hline
\end{tabular}


Table D3.2: Adjacent Land cover Area (ha.) from type 13 to 26. Adjacent land cover area data from 2004, with identification code in Table D1.

\begin{tabular}{|c|c|c|c|c|c|c|c|c|c|c|c|}
\hline Midas & 13 & 15 & 16 & 19 & 20 & 21 & 22 & 23 & 24 & 25 & 26 \\
\hline \multicolumn{12}{|l|}{2015} \\
\hline 78 & 11.5 & 6.3 & 29.9 & 5.6 & 0.0 & 634.1 & 0.0 & 9.9 & 120.0 & 97.8 & 3.6 \\
\hline 177 & 478.3 & 559.9 & 37.8 & 6.4 & 0.0 & 2746.2 & 0.5 & 37.3 & 172.5 & 55.2 & 55.8 \\
\hline 224 & 0.0 & 1.7 & 13.8 & 0.1 & 0.0 & 420.5 & 0.0 & 0.0 & 40.7 & 32.5 & 62.2 \\
\hline 3444 & 24.1 & 72.3 & 136.9 & 0.3 & 13.3 & 1750.6 & 0.0 & 0.0 & 77.5 & 10.4 & 8.0 \\
\hline 3446 & 8.9 & 42.7 & 0.1 & 2.1 & 534.5 & 539.0 & 0.0 & 0.0 & 21.7 & 8.1 & 17.2 \\
\hline 3748 & 18.2 & 28.1 & 55.0 & 0.7 & 52.9 & 952.4 & 0.0 & 0.0 & 20.8 & 2.1 & 0.9 \\
\hline 3750 & 81.1 & 37.7 & 16.7 & 0.1 & 0.0 & 257.5 & 0.0 & 0.0 & 8.6 & 11.9 & 0.0 \\
\hline 3796 & 71.5 & 26.7 & 62.4 & 0.4 & 32.4 & 799.0 & 0.0 & 0.0 & 20.9 & 5.8 & 10.8 \\
\hline 3838 & 0.0 & 27.2 & 20.6 & 0.2 & 0.0 & 370.7 & 0.0 & 0.0 & 88.3 & 5.2 & 0.0 \\
\hline 3916 & 0.0 & 45.9 & 19.8 & 0.5 & 0.0 & 348.1 & 0.0 & 0.0 & 43.5 & 0.6 & 0.0 \\
\hline 4434 & 13.7 & 23.9 & 6.1 & 26.8 & 0.0 & 791.9 & 0.0 & 0.0 & 2.1 & 0.1 & 0.0 \\
\hline 4538 & 0.0 & 0.0 & 0.0 & 6.5 & 0.0 & 169.3 & 0.0 & 0.0 & 0.0 & 1.6 & 0.0 \\
\hline 5172 & 110.3 & 60.2 & 64.8 & 27.8 & 0.6 & 1016.4 & 0.0 & 0.0 & 25.6 & 20.2 & 17.8 \\
\hline 5190 & 0.0 & 0.6 & 10.4 & 2.0 & 0.0 & 312.0 & 0.0 & 0.0 & 0.0 & 0.0 & 7.0 \\
\hline 5272 & 68.1 & 7.7 & 7.5 & 13.6 & 0.0 & 1031.3 & 0.0 & 0.0 & 142.9 & 0.0 & 0.8 \\
\hline 5274 & 566.8 & 132.0 & 17.5 & 37.3 & 5.0 & 3423.0 & 0.0 & 0.0 & 59.1 & 2.7 & 15.9 \\
\hline 5280 & 28.8 & 247.5 & 19.1 & 17.2 & 0.0 & 1515.4 & 0.0 & 0.0 & 28.2 & 19.6 & 0.0 \\
\hline 5344 & 100.8 & 7.1 & 28.9 & 9.3 & 21.5 & 1017.6 & 0.0 & 0.0 & 51.3 & 16.5 & 101.5 \\
\hline 5348 & 6.2 & 8.5 & 3.0 & 2.8 & 0.0 & 180.0 & 0.0 & 0.0 & 21.4 & 0.7 & 2.0 \\
\hline 5349 & 11.5 & 35.6 & 4.6 & 13.2 & 0.0 & 689.3 & 0.0 & 0.0 & 15.4 & 0.0 & 0.6 \\
\hline 5352 & 0.0 & 3.0 & 1.3 & 3.5 & 0.0 & 286.9 & 0.0 & 0.0 & 7.7 & 3.1 & 0.0 \\
\hline 5400 & 72.2 & 123.0 & 158.9 & 59.1 & 0.0 & 1839.4 & 43.4 & 0.0 & 24.4 & 13.9 & 14.1 \\
\hline 5408 & 1.9 & 14.7 & 19.7 & 19.2 & 0.7 & 484.2 & 0.0 & 0.0 & 14.3 & 0.0 & 0.2 \\
\hline 5448 & 21.1 & 94.5 & 135.9 & 41.6 & 0.0 & 1575.8 & 0.0 & 0.0 & 22.7 & 10.3 & 18.3 \\
\hline \multicolumn{12}{|l|}{ DEP } \\
\hline 70 & 126.5 & 13.3 & 28.4 & 10.7 & 0.0 & 555.4 & 0.0 & 0.0 & 152.7 & 34.2 & 0.0 \\
\hline 80 & NA & NA & NA & NA & NA & NA & NA & NA & NA & NA & NA \\
\hline 121 & NA & NA & NA & NA & NA & NA & NA & NA & NA & NA & NA \\
\hline 177 & 478.3 & 559.9 & 37.8 & 6.4 & 0.0 & 2746.2 & 0.5 & 37.3 & 172.5 & 55.2 & 55.8 \\
\hline 243 & 5.3 & 42.7 & 28.3 & 0.2 & 0.1 & 759.9 & 0.0 & 0.0 & 13.6 & 8.2 & 49.6 \\
\hline 262 & 0.0 & 2.8 & 26.4 & 0.1 & 0.0 & 174.2 & 0.0 & 0.0 & 81.2 & 3.5 & 0.7 \\
\hline 342 & 4.4 & 1.0 & 6.5 & 0.2 & 0.0 & 556.3 & 0.0 & 0.0 & 20.1 & 0.0 & 10.8 \\
\hline 386 & 0.0 & 0.0 & 1.7 & 0.0 & 0.2 & 32.6 & 0.0 & 3.7 & 0.0 & 0.0 & 0.0 \\
\hline 410 & 66.1 & 83.1 & 0.9 & 0.0 & 0.0 & 389.4 & 0.0 & 0.0 & 22.6 & 5.0 & 0.0 \\
\hline 447 & 2.7 & 9.2 & 3.7 & 1.3 & 0.0 & 7.4 & 0.0 & 0.0 & 0.1 & 0.0 & 0.0 \\
\hline 760 & 5.2 & 2.3 & 2.2 & 0.0 & 0.0 & 150.4 & 0.0 & 0.0 & 47.2 & 26.2 & 0.1 \\
\hline
\end{tabular}


Table D3.2: Continued

\begin{tabular}{|c|c|c|c|c|c|c|c|c|c|c|c|}
\hline Midas & 13 & 15 & 16 & 19 & 20 & 21 & 22 & 23 & 24 & 25 & 26 \\
\hline 954 & 224.2 & 309.2 & 99.7 & 0.2 & 0.2 & 2228.3 & 0.0 & 0.0 & 276.9 & 234.2 & 8.1 \\
\hline 1068 & 12.7 & 1.1 & 22.6 & 0.0 & 0.0 & 237.5 & 0.0 & 0.0 & 8.9 & 18.0 & 0.0 \\
\hline 1070 & NA & NA & NA & NA & NA & NA & NA & NA & NA & NA & NA \\
\hline 1078 & 1161.7 & 430.8 & 47.9 & 0.0 & 0.6 & 2775.0 & 0.0 & 0.7 & 232.3 & 195.0 & 26.9 \\
\hline 1088 & 15.0 & 31.7 & 17.4 & 4.7 & 0.0 & 325.6 & 0.0 & 0.2 & 31.2 & 17.3 & 0.0 \\
\hline 1150 & 0.0 & 0.0 & 31.2 & 0.0 & 0.0 & 5456.0 & 0.0 & 0.0 & 0.0 & 0.0 & 0.0 \\
\hline 1210 & 9.8 & 8.6 & 10.7 & 5.9 & 0.0 & 361.2 & 0.0 & 0.0 & 6.4 & 25.9 & 0.0 \\
\hline 2004 & 0.0 & 0.0 & 6.9 & 0.3 & 0.7 & 273.3 & 0.0 & 0.0 & 37.8 & 0.0 & 0.0 \\
\hline 2020 & 218.4 & 297.2 & 87.4 & 12.4 & 0.5 & 3665.0 & 0.0 & 0.0 & 94.2 & 198.5 & 22.5 \\
\hline 2146 & 13.3 & 18.8 & 59.7 & 0.8 & 0.8 & 1469.7 & 0.0 & 0.0 & 249.8 & 70.5 & 0.0 \\
\hline 2156 & 173.8 & 15.1 & 9.9 & 0.0 & 0.0 & 176.8 & 0.0 & 0.0 & 2.7 & 2.4 & 0.0 \\
\hline 2242 & 0.5 & 23.3 & 5.3 & 26.4 & 0.0 & 202.0 & 0.0 & 0.0 & 20.5 & 3.6 & 0.0 \\
\hline 2286 & 121.2 & 9.0 & 12.7 & 6.0 & 0.0 & 187.9 & 0.0 & 0.0 & 32.7 & 2.5 & 0.0 \\
\hline 2590 & 67.3 & 175.0 & 107.3 & 0.1 & 0.0 & 1475.5 & 0.0 & 5.2 & 450.1 & 61.1 & 1284.0 \\
\hline 2608 & 0.0 & 15.0 & 2.4 & 1.1 & 0.0 & 126.4 & 0.0 & 0.0 & 2.7 & 0.0 & 3.4 \\
\hline 2948 & 94.0 & 190.8 & 0.5 & 0.5 & 0.3 & 1345.1 & 0.0 & 4.6 & 68.0 & 95.2 & 0.8 \\
\hline 3038 & 56.7 & 64.6 & 27.6 & 0.0 & 0.0 & 458.5 & 0.0 & 0.0 & 138.0 & 44.9 & 0.0 \\
\hline 3376 & 2.1 & 0.0 & 0.9 & 0.0 & 1.0 & 14.5 & 0.0 & 0.0 & 0.0 & 0.0 & 0.0 \\
\hline 3388 & 8.2 & 3.1 & 15.5 & 0.0 & 3.8 & 66.5 & 0.0 & 0.0 & 0.6 & 0.0 & 0.0 \\
\hline 3434 & 21.7 & 46.8 & 52.3 & 1.8 & 0.0 & 381.9 & 0.0 & 0.0 & 134.6 & 95.5 & 1.0 \\
\hline 3452 & 2.8 & 14.8 & 37.4 & 0.1 & 0.0 & 172.2 & 0.0 & 12.0 & 85.1 & 40.7 & 8.3 \\
\hline 3454 & 0.0 & 33.0 & 66.0 & 0.0 & 0.0 & 528.9 & 0.0 & 0.0 & 69.9 & 38.0 & 5.6 \\
\hline 3604 & 23.6 & 16.2 & 11.0 & 2.2 & 0.0 & 238.3 & 0.0 & 2.6 & 60.5 & 4.6 & 6.7 \\
\hline 3626 & 0.0 & 0.0 & 1.9 & 0.0 & 0.0 & 19.9 & 0.0 & 0.0 & 0.0 & 0.0 & 0.0 \\
\hline 3672 & 110.2 & 77.5 & 69.5 & 37.5 & 7.9 & 844.0 & 0.0 & 0.0 & 198.8 & 13.3 & 11.2 \\
\hline 3682 & 33.4 & 51.6 & 5.2 & 0.2 & 22.4 & 227.5 & 0.0 & 1.6 & 0.0 & 0.0 & 2.8 \\
\hline 3690 & 4.5 & 0.0 & 22.2 & 3.7 & 0.0 & 137.4 & 0.0 & 0.0 & 8.8 & 2.4 & 0.0 \\
\hline 3780 & 0.0 & 2.0 & 0.7 & 0.0 & 0.4 & 18.3 & 0.0 & 0.0 & 0.0 & 0.0 & 0.0 \\
\hline 3814 & 0.7 & 21.8 & 18.9 & 0.1 & 0.0 & 160.6 & 0.0 & 0.0 & 39.9 & 1.8 & 6.2 \\
\hline 3830 & 40.0 & 17.6 & 16.1 & 0.0 & 0.0 & 106.0 & 0.0 & 0.0 & 59.6 & 2.1 & 0.4 \\
\hline 3884 & 10.8 & 0.0 & 1.5 & 0.0 & 0.0 & 18.7 & 0.0 & 0.0 & 0.0 & 0.0 & 0.0 \\
\hline 3920 & 0.0 & 3.0 & 5.8 & 0.1 & 0.0 & 120.9 & 0.0 & 0.0 & 7.3 & 5.4 & 0.0 \\
\hline 4272 & 0.0 & 0.0 & 5.1 & 2.8 & 0.3 & 60.3 & 0.0 & 0.0 & 8.0 & 0.9 & 0.0 \\
\hline 4316 & 5.9 & 1.0 & 12.6 & 1.3 & 0.3 & 65.5 & 0.0 & 0.0 & 8.2 & 11.4 & 0.3 \\
\hline 4322 & 0.0 & 0.0 & 8.1 & 2.2 & 0.3 & 74.3 & 0.0 & 0.0 & 9.9 & 12.2 & 0.0 \\
\hline 4328 & 53.2 & 46.6 & 89.8 & 59.3 & 0.0 & 1159.4 & 0.0 & 0.0 & 29.8 & 33.3 & 0.0 \\
\hline 4330 & 2.5 & 0.0 & 9.3 & 0.7 & 0.0 & 64.1 & 0.0 & 0.0 & 3.4 & 0.0 & 0.0 \\
\hline 4336 & 47.4 & 10.8 & 70.5 & 18.0 & 0.2 & 463.2 & 44.1 & 0.0 & 53.0 & 82.1 & 0.0 \\
\hline 4388 & 3.6 & 34.2 & 4.4 & 6.4 & 1.1 & 209.4 & 0.0 & 0.0 & 0.4 & 10.5 & 0.0 \\
\hline 4452 & 0.0 & 0.4 & 5.3 & 0.6 & 0.0 & 14.2 & 0.0 & 0.0 & 0.0 & 0.0 & 0.0 \\
\hline 4492 & NA & NA & NA & NA & NA & NA & NA & NA & NA & NA & NA \\
\hline
\end{tabular}


Table D3.2: Continued

\begin{tabular}{|c|c|c|c|c|c|c|c|c|c|c|c|}
\hline Midas & 13 & 15 & 16 & 19 & 20 & 21 & 22 & 23 & 24 & 25 & 26 \\
\hline 4606 & 0.9 & 0.0 & 34.0 & 5.0 & 0.0 & 185.6 & 0.0 & 0.0 & 7.9 & 4.5 & 0.0 \\
\hline 4608 & 0.0 & 1.7 & 13.6 & 7.4 & 0.0 & 68.3 & 0.0 & 0.0 & 0.3 & 5.4 & 0.0 \\
\hline 4610 & 0.0 & 0.0 & 4.6 & 0.2 & 0.0 & 14.6 & 0.0 & 0.0 & 0.0 & 0.0 & 0.0 \\
\hline 4612 & 0.0 & 0.0 & 6.0 & 0.2 & 0.0 & 15.0 & 0.0 & 0.0 & 0.0 & 0.0 & 0.0 \\
\hline 4614 & NA & NA & NA & NA & NA & NA & NA & NA & NA & NA & NA \\
\hline 4618 & 5.0 & 0.0 & 0.2 & 0.3 & 0.0 & 5.1 & 0.0 & 0.0 & 0.0 & 0.0 & 0.0 \\
\hline 4620 & NA & NA & NA & NA & NA & NA & NA & NA & NA & NA & NA \\
\hline 4622 & 15.2 & 0.4 & 38.8 & 10.8 & 0.0 & 377.0 & 0.0 & 0.0 & 20.1 & 38.9 & 0.0 \\
\hline 4624 & 0.2 & 1.3 & 40.1 & 8.3 & 0.0 & 87.9 & 0.0 & 0.0 & 3.7 & 3.6 & 0.0 \\
\hline 4628 & 0.2 & 0.0 & 8.3 & 2.6 & 0.0 & 18.6 & 0.0 & 0.0 & 7.2 & 3.7 & 0.0 \\
\hline 4630 & 0.0 & 0.0 & 17.2 & 5.2 & 0.0 & 104.8 & 0.0 & 0.0 & 0.2 & 33.2 & 0.0 \\
\hline 4766 & 130.6 & 236.7 & 21.7 & 118.6 & 0.0 & 1997.5 & 0.0 & 0.0 & 145.3 & 119.0 & 0.0 \\
\hline 4782 & 48.9 & 7.3 & 1.7 & 5.9 & 0.0 & 376.8 & 0.0 & 0.0 & 8.1 & 0.0 & 29.1 \\
\hline 4788 & 0.0 & 0.0 & 0.3 & 6.3 & 0.0 & 85.7 & 0.0 & 0.0 & 0.2 & 0.0 & 0.0 \\
\hline 4800 & 0.0 & 9.8 & 11.3 & 11.6 & 0.0 & 55.6 & 0.0 & 0.0 & 3.2 & 0.0 & 0.0 \\
\hline 4802 & NA & NA & NA & NA & NA & NA & NA & NA & NA & NA & NA \\
\hline 4806 & 0.0 & 5.3 & 16.1 & 4.1 & 0.0 & 103.1 & 20.2 & 0.0 & 1.9 & 2.2 & 0.0 \\
\hline 4822 & 0.0 & 3.2 & 18.8 & 6.2 & 0.0 & 138.3 & 0.0 & 0.0 & 1.9 & 0.1 & 0.0 \\
\hline 4852 & 46.7 & 30.9 & 70.4 & 30.8 & 0.3 & 504.5 & 0.0 & 0.0 & 17.5 & 0.0 & 8.1 \\
\hline 4857 & 1.1 & 3.2 & 7.1 & 4.7 & 0.0 & 85.8 & 0.0 & 0.0 & 2.3 & 0.0 & 0.0 \\
\hline 4894 & 8.1 & 10.2 & 26.7 & 4.2 & 0.0 & 230.2 & 0.0 & 0.0 & 10.1 & 0.0 & 0.8 \\
\hline 4896 & 176.9 & 29.5 & 22.7 & 10.5 & 0.0 & 480.9 & 0.0 & 0.0 & 0.0 & 13.8 & 0.2 \\
\hline 5024 & 0.0 & 11.9 & 27.8 & 0.6 & 0.0 & 223.6 & 0.0 & 0.0 & 7.5 & 6.5 & 0.0 \\
\hline 5172 & 110.3 & 60.2 & 64.8 & 27.8 & 0.6 & 1016.4 & 0.0 & 0.0 & 25.6 & 20.2 & 17.8 \\
\hline 5174 & 56.6 & 25.7 & 22.2 & 11.6 & 0.0 & 158.9 & 0.0 & 0.0 & 5.8 & 2.9 & 1.1 \\
\hline 5198 & 12.0 & 0.0 & 0.3 & 0.0 & 0.0 & 39.8 & 0.0 & 0.0 & 0.0 & 0.0 & 0.0 \\
\hline 5222 & 10.8 & 27.7 & 21.4 & 0.0 & 0.0 & 176.5 & 0.0 & 0.0 & 14.1 & 4.0 & 19.8 \\
\hline 5236 & 70.2 & 164.0 & 146.8 & 1.1 & 0.0 & 2212.6 & 0.0 & 0.0 & 399.1 & 47.5 & 50.9 \\
\hline 5240 & 3.2 & 6.6 & 25.1 & 0.0 & 0.0 & 213.7 & 0.0 & 0.0 & 55.6 & 5.2 & 0.9 \\
\hline 5280 & 28.8 & 247.5 & 19.1 & 17.2 & 0.0 & 1515.4 & 0.0 & 0.0 & 28.2 & 19.6 & 0.0 \\
\hline 5344 & 100.8 & 7.1 & 28.9 & 9.3 & 21.5 & 1017.6 & 0.0 & 0.0 & 51.3 & 16.5 & 101.5 \\
\hline 5348 & 6.2 & 8.5 & 3.0 & 2.8 & 0.0 & 180.0 & 0.0 & 0.0 & 21.4 & 0.7 & 2.0 \\
\hline 5349 & 11.5 & 35.6 & 4.6 & 13.2 & 0.0 & 689.3 & 0.0 & 0.0 & 15.4 & 0.0 & 0.6 \\
\hline 5352 & 0.0 & 3.0 & 1.3 & 3.5 & 0.0 & 286.9 & 0.0 & 0.0 & 7.7 & 3.1 & 0.0 \\
\hline 5386 & 10.2 & 55.8 & 22.8 & 19.9 & 0.2 & 148.5 & 0.0 & 0.0 & 2.5 & 0.0 & 0.0 \\
\hline 5400 & 72.2 & 123.0 & 158.9 & 59.1 & 0.0 & 1839.4 & 43.4 & 0.0 & 24.4 & 13.9 & 14.1 \\
\hline 5408 & 1.9 & 14.7 & 19.7 & 19.2 & 0.7 & 484.2 & 0.0 & 0.0 & 14.3 & 0.0 & 0.2 \\
\hline 5416 & 21.9 & 57.1 & 33.3 & 14.5 & 1.7 & 466.5 & 0.0 & 0.0 & 6.3 & 0.0 & 0.2 \\
\hline 5448 & 21.1 & 94.5 & 135.9 & 41.6 & 0.0 & 1575.8 & 0.0 & 0.0 & 22.7 & 10.3 & 18.3 \\
\hline 5458 & 9.0 & 42.0 & 15.0 & 2.0 & 0.0 & 208.5 & 0.0 & 0.0 & 35.8 & 0.0 & 0.0 \\
\hline 5490 & NA & NA & NA & NA & NA & NA & NA & NA & NA & NA & NA \\
\hline
\end{tabular}


Table 3.2: Continued

\begin{tabular}{|c|c|c|c|c|c|c|c|c|c|c|c|}
\hline Midas & 13 & 15 & 16 & 19 & 20 & 21 & 22 & 23 & 24 & 25 & 26 \\
\hline 5682 & 46.4 & 23.7 & 19.2 & 11.8 & 0.0 & 214.4 & 27.9 & 0.0 & 1.9 & 0.9 & 0.0 \\
\hline 5690 & 8.1 & 11.2 & 15.9 & 14.5 & 0.0 & 129.9 & 0.0 & 0.0 & 0.3 & 0.0 & 0.0 \\
\hline 5710 & 6.0 & 9.9 & 25.1 & 10.6 & 0.0 & 144.3 & 0.0 & 0.0 & 10.3 & 5.4 & 0.0 \\
\hline 5780 & 39.1 & 122.7 & 247.5 & 1.1 & 1.1 & 2120.9 & 1.0 & 0.0 & 452.8 & 336.9 & 50.8 \\
\hline 5814 & 21.3 & 6.9 & 20.4 & 5.4 & 0.0 & 447.7 & 0.0 & 0.0 & 60.4 & 0.6 & 13.6 \\
\hline 9685 & 13.5 & 20.5 & 4.1 & 0.8 & 0.0 & 291.6 & 0.0 & 0.0 & 17.7 & 3.7 & 0.0 \\
\hline 9931 & 3.3 & 10.9 & 21.9 & 0.0 & 0.0 & 268.1 & 0.0 & 0.0 & 68.4 & 13.0 & 77.5 \\
\hline \multicolumn{12}{|l|}{ LEA } \\
\hline 5780 & 39.1 & 122.7 & 247.5 & 1.1 & 1.1 & 2120.9 & 1.0 & 0.0 & 452.8 & 336.9 & 50.8 \\
\hline 3418 & 1.5 & 6.3 & 17.8 & 0.0 & 0.0 & 176.7 & 0.0 & 0.0 & 88.3 & 18.0 & 1.1 \\
\hline 5780 & 39.1 & 122.7 & 247.5 & 1.1 & 1.1 & 2120.9 & 1.0 & 0.0 & 452.8 & 336.9 & 50.8 \\
\hline 3130 & 1.0 & 6.1 & 6.3 & 0.0 & 0.0 & 94.1 & 0.0 & 0.0 & 94.6 & 36.4 & 1.6 \\
\hline 3382 & NA & NA & NA & NA & NA & NA & NA & NA & NA & NA & NA \\
\hline 3424 & 1.2 & 5.5 & 7.4 & 0.0 & 0.0 & 75.5 & 0.0 & 0.0 & 23.0 & 4.8 & 9.6 \\
\hline 3199 & 5.7 & 17.6 & 10.0 & 0.0 & 0.0 & 69.9 & 0.0 & 0.0 & 53.6 & 0.0 & 39.4 \\
\hline 3134 & 23.6 & 116.5 & 87.4 & 0.1 & 0.0 & 630.5 & 0.0 & 0.0 & 601.2 & 518.8 & 43.2 \\
\hline 3416 & 0.2 & 0.7 & 36.8 & 0.1 & 0.0 & 183.8 & 0.0 & 0.0 & 133.5 & 4.1 & 3.5 \\
\hline 9685 & 13.5 & 20.5 & 4.1 & 0.8 & 0.0 & 291.6 & 0.0 & 0.0 & 17.7 & 3.7 & 0.0 \\
\hline 3420 & 9.5 & 9.5 & 14.0 & 0.1 & 0.0 & 94.7 & 0.0 & 0.0 & 20.3 & 16.0 & 1.4 \\
\hline 3454 & 0.0 & 33.0 & 66.0 & 0.0 & 0.0 & 528.9 & 0.0 & 0.0 & 69.9 & 38.0 & 5.6 \\
\hline 5582 & 2.0 & 1.4 & 9.8 & 0.0 & 0.0 & 27.4 & 0.0 & 0.0 & 32.1 & 35.2 & 0.1 \\
\hline 3134 & 23.6 & 116.5 & 87.4 & 0.1 & 0.0 & 630.5 & 0.0 & 0.0 & 601.2 & 518.8 & 43.2 \\
\hline 5780 & 39.1 & 122.7 & 247.5 & 1.1 & 1.1 & 2120.9 & 1.0 & 0.0 & 452.8 & 336.9 & 50.8 \\
\hline 5780 & 39.1 & 122.7 & 247.5 & 1.1 & 1.1 & 2120.9 & 1.0 & 0.0 & 452.8 & 336.9 & 50.8 \\
\hline 3132 & 9.7 & 19.4 & 8.4 & 0.0 & 0.0 & 311.8 & 0.0 & 0.0 & 111.6 & 99.7 & 0.1 \\
\hline 3126 & 0.0 & 7.2 & 7.6 & 0.0 & 0.0 & 51.8 & 0.0 & 0.0 & 38.4 & 33.7 & 1.2 \\
\hline 3234 & 0.0 & 7.2 & 5.8 & 0.0 & 0.0 & 99.4 & 0.0 & 0.0 & 34.9 & 5.8 & 0.1 \\
\hline 3374 & 14.4 & 15.0 & 12.3 & 0.0 & 0.1 & 296.6 & 0.0 & 0.2 & 84.0 & 14.3 & 2.4 \\
\hline 3134 & 23.6 & 116.5 & 87.4 & 0.1 & 0.0 & 630.5 & 0.0 & 0.0 & 601.2 & 518.8 & 43.2 \\
\hline 3452 & 2.8 & 14.8 & 37.4 & 0.1 & 0.0 & 172.2 & 0.0 & 12.0 & 85.1 & 40.7 & 8.3 \\
\hline 3454 & 0.0 & 33.0 & 66.0 & 0.0 & 0.0 & 528.9 & 0.0 & 0.0 & 69.9 & 38.0 & 5.6 \\
\hline 3448 & 5.5 & 6.6 & 7.9 & 0.0 & 0.0 & 43.1 & 0.0 & 0.0 & 56.3 & 5.3 & 0.0 \\
\hline 3232 & 1.1 & 2.5 & 8.7 & 0.0 & 0.0 & 76.6 & 0.0 & 0.0 & 18.6 & 3.2 & 6.4 \\
\hline 3456 & 0.0 & 3.9 & 23.6 & 0.3 & 0.3 & 185.7 & 0.0 & 0.0 & 130.2 & 140.0 & 0.0 \\
\hline 5780 & 39.1 & 122.7 & 247.5 & 1.1 & 1.1 & 2120.9 & 1.0 & 0.0 & 452.8 & 336.9 & 50.8 \\
\hline
\end{tabular}


Table D4: Road, Direct Watershed, and Lake Areas (ha.). Table of road coverage area, direct watershed area, and lake area in hectares for 2015, DEP, and LEA.

\begin{tabular}{|c|c|c|c|}
\hline Midas & $\begin{array}{c}\text { Road } \\
\text { Area, ha }\end{array}$ & $\begin{array}{c}\text { Lake } \\
\text { Area, ha }\end{array}$ & $\begin{array}{c}\text { Watershed } \\
\text { Area, ha }\end{array}$ \\
\hline \multicolumn{4}{|l|}{2015} \\
\hline 78 & 23.7 & 644.4 & 4493.2 \\
\hline 177 & 49.7 & 2755.9 & 9867.6 \\
\hline 224 & 13.3 & 420.5 & 1483.4 \\
\hline 3444 & 109.9 & 1761.2 & 10802.4 \\
\hline 3446 & 21.5 & 534.4 & 2009.2 \\
\hline 3748 & 34.7 & 952.3 & 3558.2 \\
\hline 3750 & 42.8 & 259.4 & 3772.5 \\
\hline 3796 & 75.7 & 799.4 & 14806.7 \\
\hline 3838 & 76.3 & 371.0 & 5455.2 \\
\hline 3916 & 17.7 & 349.7 & 1239.9 \\
\hline 4434 & 8.5 & 792.0 & 2936.5 \\
\hline 4538 & 6.3 & 169.2 & 814.8 \\
\hline 5172 & 190.4 & 1068.5 & 25212.9 \\
\hline 5190 & 12.2 & 313.2 & 1598.1 \\
\hline 5272 & 42.8 & 1033.3 & 6080.3 \\
\hline 5274 & 77.1 & 3434.3 & 11878.4 \\
\hline 5280 & 104.7 & 1636.7 & 12428.0 \\
\hline 5344 & 47.2 & 1019.2 & 5543.1 \\
\hline 5348 & 13.7 & 180.0 & 1136.3 \\
\hline 5349 & 22.3 & 689.2 & 1916.4 \\
\hline 5352 & 18.3 & 287.0 & 1077.4 \\
\hline 5400 & 112.4 & 1841.2 & 11496.3 \\
\hline 5408 & 26.3 & 484.2 & 2650.3 \\
\hline 5448 & 69.8 & 1578.2 & 8281.9 \\
\hline \multicolumn{4}{|l|}{ DEP } \\
\hline 70 & 46.9 & 555.4 & 4711.7 \\
\hline 80 & 170.1 & 1893.8 & 23731.6 \\
\hline 121 & 145.4 & 6968.3 & 69004.6 \\
\hline 177 & 49.7 & 2755.9 & 9867.6 \\
\hline 243 & 11.1 & 766.7 & 5450.8 \\
\hline 262 & 11.4 & 174.2 & 1449.2 \\
\hline 342 & 15.2 & 556.4 & 2025.8 \\
\hline 386 & 4.9 & 32.6 & 270.9 \\
\hline 410 & 1.3 & 389.4 & 4481.5 \\
\hline 447 & 0.1 & 7.4 & 332.2 \\
\hline 760 & 15.7 & 150.4 & 1295.5 \\
\hline
\end{tabular}

\begin{tabular}{|c|c|c|c|}
\hline Midas & $\begin{array}{c}\text { Road } \\
\text { Area, ha }\end{array}$ & $\begin{array}{c}\text { Lake } \\
\text { Area, ha }\end{array}$ & $\begin{array}{c}\text { Watershed } \\
\text { Area, ha }\end{array}$ \\
\hline 954 & 45.3 & 2268.8 & 15601.7 \\
\hline 1068 & 12.8 & 237.5 & 1062.3 \\
\hline 1070 & 56.9 & 6441.4 & 17120.5 \\
\hline 1078 & 0.2 & 2797.3 & 22131.0 \\
\hline 1088 & 9.1 & 325.6 & 4689.9 \\
\hline 1150 & 9.7 & 5456.0 & 13431.5 \\
\hline 1210 & 25.4 & 361.2 & 3542.6 \\
\hline 2004 & 7.8 & 273.3 & 1309.8 \\
\hline 2020 & 63.7 & 3694.2 & 20759.1 \\
\hline 2146 & 38.5 & 1469.8 & 5621.1 \\
\hline 2156 & 27.9 & 176.8 & 3255.5 \\
\hline 2242 & 19.2 & 202.0 & 1618.8 \\
\hline 2286 & 114.8 & 252.6 & 17207.7 \\
\hline 2590 & 176.1 & 1484.0 & 26967.5 \\
\hline 2608 & 9.9 & 126.4 & 1591.6 \\
\hline 2948 & NA & 1348.3 & 9635.9 \\
\hline 3038 & 22.5 & 465.3 & 6978.4 \\
\hline 3376 & 2.1 & 14.5 & 219.1 \\
\hline 3388 & 5.4 & 66.5 & 346.2 \\
\hline 3434 & 60.7 & 381.9 & 4063.6 \\
\hline 3452 & 24.3 & 172.2 & 2359.8 \\
\hline 3454 & 29.9 & 532.7 & 2636.4 \\
\hline 3604 & 28.1 & 247.0 & 3852.2 \\
\hline 3626 & 3.7 & 19.8 & 140.7 \\
\hline 3672 & 53.7 & 844.0 & 19574.9 \\
\hline 3682 & 35.3 & 228.3 & 6913.7 \\
\hline 3690 & 12.7 & 137.7 & 1292.6 \\
\hline 3780 & 0.9 & 18.3 & 78.9 \\
\hline 3814 & 13.6 & 160.3 & 862.7 \\
\hline 3830 & 18.5 & 106.0 & 2305.5 \\
\hline 3884 & 1.3 & 18.7 & 85.0 \\
\hline 3920 & 11.9 & 120.9 & 999.6 \\
\hline 4272 & 2.0 & 60.3 & 262.1 \\
\hline 4316 & 35.2 & 74.3 & 5048.5 \\
\hline 4322 & 6.3 & 74.2 & 677.0 \\
\hline 4328 & 53.4 & 1159.5 & 7305.3 \\
\hline 4330 & 3.9 & 64.1 & 572.3 \\
\hline 4336 & 46.5 & 482.1 & 5825.1 \\
\hline
\end{tabular}


Table D4: Continued

\begin{tabular}{|c|c|c|c|c|c|c|c|}
\hline Midas & $\begin{array}{c}\text { Road } \\
\text { Area, ha }\end{array}$ & $\begin{array}{c}\text { Lake } \\
\text { Area, ha }\end{array}$ & $\begin{array}{c}\text { Watershed } \\
\text { Area, ha }\end{array}$ & Midas & $\begin{array}{c}\text { Road } \\
\text { Area, ha }\end{array}$ & $\begin{array}{c}\text { Lake } \\
\text { Area, ha }\end{array}$ & $\begin{array}{c}\text { Watershed } \\
\text { Area, ha }\end{array}$ \\
\hline 4388 & 15.1 & 209.3 & 1984.9 & 5416 & 31.8 & 466.5 & 2945.7 \\
\hline 4452 & 3.1 & 14.2 & 195.4 & 5448 & 69.8 & 1578.2 & 8281.9 \\
\hline 4492 & 12.8 & NA & NA & 5458 & 24.2 & 208.5 & 3601.2 \\
\hline 4606 & 9.0 & 185.6 & 752.9 & 5490 & 2.6 & 63.8 & 421.8 \\
\hline 4608 & 2.0 & 68.3 & 481.5 & 5682 & 87.9 & 248.9 & 9696.8 \\
\hline 4610 & 3.0 & 14.6 & 108.7 & 5690 & 15.7 & 129.9 & 1317.7 \\
\hline 4612 & 2.7 & 15.0 & 336.9 & 5710 & 15.4 & 144.4 & 1231.5 \\
\hline 4614 & 7.2 & 41.5 & 448.1 & 5780 & 161.1 & 2120.9 & 15649.9 \\
\hline 4618 & 1.0 & 5.1 & 72.5 & 5814 & 22.0 & 447.7 & 1917.4 \\
\hline 4620 & 0.7 & 15.0 & 109.6 & 9685 & 17.0 & 291.6 & 1227.4 \\
\hline 4622 & 17.6 & 377.0 & 1683.1 & 9931 & 16.6 & 268.1 & 1169.6 \\
\hline 4624 & 11.3 & 87.9 & 598.6 & LEA & & & \\
\hline 4628 & 7.3 & 18.6 & 167.1 & 5780 & 161.1 & 2120.9 & 15649.9 \\
\hline 4630 & 8.5 & 104.8 & 857.0 & 3418 & 19.6 & 176.7 & 1193.8 \\
\hline 4766 & 31.4 & 2000.3 & 11164.1 & 5780 & 161.1 & 2120.9 & 15649.9 \\
\hline 4782 & 10.4 & 376.8 & 2447.9 & 3130 & 9.8 & 94.2 & 620.8 \\
\hline 4788 & 2.1 & 85.7 & 509.2 & 3382 & 5.6 & 126.4 & 383.6 \\
\hline 4800 & 8.0 & 55.6 & 320.3 & 3424 & 11.9 & 75.5 & 1241.6 \\
\hline 4802 & 3.1 & 58.1 & 294.3 & 3199 & 7.1 & 69.9 & 776.6 \\
\hline 4806 & 11.9 & 103.1 & 839.1 & 3134 & 59.2 & 630.5 & 5516.3 \\
\hline 4822 & 17.4 & 138.3 & 823.6 & 3416 & 27.3 & 183.8 & 1515.1 \\
\hline 4852 & 73.1 & 514.6 & 4474.2 & 9685 & 17.0 & 291.6 & 1227.4 \\
\hline 4857 & 6.8 & 85.7 & 756.2 & 3420 & 8.4 & 94.7 & 712.2 \\
\hline 4894 & 17.1 & 230.2 & 913.8 & 3454 & 29.9 & 532.7 & 2636.4 \\
\hline 4896 & 70.8 & 484.7 & 7431.2 & 5582 & 11.0 & 27.4 & 694.8 \\
\hline 5024 & 133.8 & 223.6 & 1440.1 & 3134 & 59.2 & 630.5 & 5516.3 \\
\hline 5172 & 190.4 & 1068.5 & 25212.9 & 5780 & 161.1 & 2120.9 & 15649.9 \\
\hline 5174 & 20.6 & 158.9 & 1537.0 & 5780 & 161.1 & 2120.9 & 15649.9 \\
\hline 5198 & 9.4 & 39.8 & 616.5 & 3132 & 14.0 & 311.9 & 1257.0 \\
\hline 5222 & 44.5 & 176.5 & 4959.8 & 3126 & 6.8 & 51.8 & 405.1 \\
\hline 5236 & 107.6 & 2215.4 & 10319.9 & 3234 & 15.3 & 99.4 & 1331.4 \\
\hline 5240 & 12.8 & 214.1 & 857.3 & 3374 & 8.3 & 296.5 & 1318.1 \\
\hline 5280 & 104.7 & 1636.7 & 12428.0 & 3134 & 59.2 & 630.5 & 5516.3 \\
\hline 5344 & 47.2 & 1019.2 & 5543.1 & 3452 & 24.3 & 172.2 & 2359.8 \\
\hline 5348 & 13.7 & 180.0 & 1136.3 & 3454 & 29.9 & 532.7 & 2636.4 \\
\hline 5349 & 22.3 & 689.2 & 1916.4 & 3448 & 5.7 & 43.1 & 717.1 \\
\hline 5352 & 18.3 & 287.0 & 1077.4 & 3232 & 12.4 & 76.6 & 1036.0 \\
\hline 5386 & 25.6 & 150.4 & 2885.7 & 3456 & 12.0 & 185.7 & 1533.8 \\
\hline 5400 & 112.4 & 1841.2 & 11496.3 & 5780 & 161.1 & 2120.9 & 15649.9 \\
\hline 5408 & 26.3 & 484.2 & 2650.3 & & & & \\
\hline
\end{tabular}




\section{APPENDIX E: PRECIPITATION DATA}

Table E1: Precipitation (precip) data. Reported beginning from both January to the sampling date and May to the sampling date, including the maximum, average, and sum values (inches) over this timeframe.

\begin{tabular}{|c|c|c|c|c|c|c|}
\hline Midas & $\begin{array}{c}\text { Maximum } \\
\text { Precip } \\
\text { January }\end{array}$ & $\begin{array}{c}\text { Average } \\
\text { Precip } \\
\text { January }\end{array}$ & $\begin{array}{c}\text { Sum } \\
\text { Precip } \\
\text { January }\end{array}$ & $\begin{array}{c}\text { Maximum } \\
\text { Precip } \\
\text { May } \\
\end{array}$ & $\begin{array}{c}\text { Average } \\
\text { Precip } \\
\text { May }\end{array}$ & $\begin{array}{c}\text { Sum } \\
\text { Precip } \\
\text { May }\end{array}$ \\
\hline \multicolumn{7}{|l|}{2015} \\
\hline 78 & 1.77 & 0.06 & 12.80 & 1.13 & 0.08 & 8.21 \\
\hline 177 & 3.92 & 0.08 & 17.41 & 3.92 & 0.10 & 11.02 \\
\hline 224 & 1.37 & 0.12 & 29.33 & 1.35 & 0.15 & 17.76 \\
\hline 3444 & 1.30 & 0.07 & 14.14 & 1.30 & 0.11 & 9.47 \\
\hline 3446 & 1.30 & 0.07 & 14.37 & 1.30 & 0.10 & 9.70 \\
\hline 3748 & 1.30 & 0.07 & 16.57 & 1.30 & 0.11 & 11.90 \\
\hline 3750 & 1.30 & 0.07 & 14.37 & 1.30 & 0.10 & 9.70 \\
\hline 3796 & 1.30 & 0.07 & 14.14 & 1.30 & 0.11 & 9.47 \\
\hline 3838 & 1.19 & 0.06 & 14.82 & 1.19 & 0.08 & 8.88 \\
\hline 3916 & 1.19 & 0.06 & 14.82 & 1.19 & 0.08 & 8.88 \\
\hline 4434 & 3.92 & 0.08 & 17.41 & 3.92 & 0.10 & 11.02 \\
\hline 4538 & 3.92 & 0.08 & 17.93 & 3.92 & 0.10 & 11.54 \\
\hline 5172 & 1.77 & 0.05 & 10.65 & 0.94 & 0.07 & 6.06 \\
\hline 5190 & 1.65 & 0.10 & 20.24 & 1.30 & 0.12 & 12.46 \\
\hline 5272 & 1.65 & 0.10 & 20.24 & 1.30 & 0.12 & 12.46 \\
\hline 5274 & 1.65 & 0.10 & 20.24 & 1.30 & 0.12 & 12.46 \\
\hline 5280 & 1.65 & 0.11 & 20.24 & 1.30 & 0.13 & 12.46 \\
\hline 5344 & 1.65 & 0.11 & 20.24 & 1.30 & 0.13 & 12.46 \\
\hline 5348 & 1.65 & 0.11 & 20.17 & 1.30 & 0.13 & 12.39 \\
\hline 5349 & 1.65 & 0.10 & 20.24 & 1.30 & 0.12 & 12.46 \\
\hline 5352 & 1.65 & 0.11 & 20.24 & 1.30 & 0.13 & 12.46 \\
\hline 5400 & 1.65 & 0.11 & 22.42 & 1.49 & 0.13 & 14.66 \\
\hline 5408 & 1.77 & 0.05 & 9.71 & 0.74 & 0.06 & 5.12 \\
\hline 5448 & 1.77 & 0.05 & 9.71 & 0.74 & 0.06 & 5.12 \\
\hline \multicolumn{7}{|l|}{ DEP } \\
\hline 70 & 1.50 & 0.08 & 18.18 & 0.77 & 0.07 & 7.25 \\
\hline 80 & 2.12 & 0.14 & 27.91 & 1.71 & 0.14 & 14.60 \\
\hline 121 & 1.38 & 0.15 & 29.77 & 1.26 & 0.18 & 19.17 \\
\hline 177 & 1.48 & 0.06 & 15.23 & 1.48 & 0.08 & 11.19 \\
\hline 243 & 2.99 & 0.14 & 29.49 & 2.99 & 0.15 & 18.08 \\
\hline 262 & 1.67 & 0.10 & 24.34 & 1.67 & 0.10 & 12.12 \\
\hline 342 & 2.70 & 0.14 & 34.61 & 2.70 & 0.16 & 19.89 \\
\hline 386 & 1.54 & 0.13 & 31.64 & 1.54 & 0.15 & 16.92 \\
\hline 410 & 2.70 & 0.14 & 34.61 & 2.70 & 0.16 & 19.89 \\
\hline 447 & 2.64 & 0.12 & 31.46 & 2.64 & 0.15 & 22.50 \\
\hline 760 & 1.67 & 0.10 & 24.34 & 1.67 & 0.10 & 12.12 \\
\hline
\end{tabular}


Table E1: Continued

\begin{tabular}{|c|c|c|c|c|c|c|}
\hline Midas & $\begin{array}{c}\text { Maximum } \\
\text { Precip } \\
\text { January }\end{array}$ & $\begin{array}{c}\text { Average } \\
\text { Precip } \\
\text { January }\end{array}$ & $\begin{array}{c}\text { Sum } \\
\text { Precip } \\
\text { January } \\
\end{array}$ & $\begin{array}{c}\text { Maximum } \\
\text { Precip } \\
\text { May } \\
\end{array}$ & $\begin{array}{c}\text { Average } \\
\text { Precip } \\
\text { May } \\
\end{array}$ & $\begin{array}{c}\text { Sum } \\
\text { Precip } \\
\text { May } \\
\end{array}$ \\
\hline 954 & 1.79 & 0.12 & 23.04 & 1.79 & 0.13 & 12.96 \\
\hline 1068 & 1.38 & 0.15 & 29.77 & 1.26 & 0.18 & 19.17 \\
\hline 1070 & 1.38 & 0.15 & 29.77 & 1.26 & 0.18 & 19.17 \\
\hline 1078 & 1.38 & 0.16 & 29.77 & 1.26 & 0.18 & 19.17 \\
\hline 1088 & 1.38 & 0.16 & 29.77 & 1.26 & 0.18 & 19.17 \\
\hline 1150 & 2.40 & 0.13 & 27.27 & 2.40 & 0.13 & 17.19 \\
\hline 1210 & 1.48 & 0.05 & 12.39 & 1.48 & 0.07 & 8.35 \\
\hline 2004 & 1.79 & 0.12 & 23.04 & 1.79 & 0.13 & 12.96 \\
\hline 2020 & 1.46 & 0.13 & 24.82 & 1.08 & 0.13 & 13.41 \\
\hline 2146 & 1.46 & 0.13 & 24.98 & 1.08 & 0.13 & 13.57 \\
\hline 2156 & 2.12 & 0.14 & 27.91 & 1.71 & 0.14 & 14.60 \\
\hline 2242 & 1.46 & 0.13 & 24.98 & 1.08 & 0.13 & 13.57 \\
\hline 2286 & 2.04 & 0.11 & 22.78 & 0.96 & 0.09 & 10.20 \\
\hline 2590 & 1.54 & 0.07 & 17.24 & 1.21 & 0.07 & 8.33 \\
\hline 2608 & 1.54 & 0.07 & 17.24 & 1.21 & 0.07 & 8.33 \\
\hline 2948 & 1.67 & 0.10 & 24.34 & 1.67 & 0.10 & 12.12 \\
\hline 3038 & 1.46 & 0.13 & 26.35 & 1.08 & 0.13 & 14.94 \\
\hline 3376 & 1.89 & 0.13 & 30.26 & 1.61 & 0.12 & 13.71 \\
\hline 3388 & 2.92 & 0.09 & 22.21 & 1.27 & 0.08 & 10.03 \\
\hline 3434 & 2.92 & 0.09 & 21.09 & 1.27 & 0.07 & 8.91 \\
\hline 3452 & 3.15 & 0.13 & 30.48 & 3.15 & 0.10 & 12.67 \\
\hline 3454 & 1.89 & 0.13 & 29.19 & 1.61 & 0.12 & 12.64 \\
\hline 3604 & 1.91 & 0.09 & 20.63 & 1.91 & 0.10 & 11.35 \\
\hline 3626 & 2.92 & 0.09 & 21.09 & 1.27 & 0.07 & 8.91 \\
\hline 3672 & 1.50 & 0.08 & 18.32 & 0.77 & 0.07 & 7.39 \\
\hline 3682 & 1.50 & 0.08 & 18.32 & 0.77 & 0.07 & 7.39 \\
\hline 3690 & 2.92 & 0.09 & 21.09 & 1.27 & 0.07 & 8.91 \\
\hline 3780 & 2.10 & 0.09 & 20.08 & 0.99 & 0.08 & 8.58 \\
\hline 3814 & 1.91 & 0.09 & 21.04 & 1.91 & 0.10 & 11.76 \\
\hline 3830 & 2.46 & 0.10 & 24.20 & 1.23 & 0.08 & 9.88 \\
\hline 3884 & 2.87 & 0.13 & 31.31 & 2.30 & 0.09 & 11.40 \\
\hline 3916 & 3.66 & 0.12 & 27.53 & 2.12 & 0.07 & 8.11 \\
\hline 3920 & 3.66 & 0.12 & 27.53 & 2.12 & 0.07 & 8.11 \\
\hline 4272 & 2.12 & 0.13 & 24.15 & 1.39 & 0.12 & 10.84 \\
\hline 4316 & 2.04 & 0.12 & 21.64 & 0.73 & 0.10 & 9.06 \\
\hline 4322 & 2.04 & 0.11 & 21.69 & 0.73 & 0.09 & 9.11 \\
\hline 4328 & 1.48 & 0.05 & 11.98 & 1.48 & 0.07 & 7.94 \\
\hline 4330 & 1.48 & 0.05 & 11.98 & 1.48 & 0.07 & 7.94 \\
\hline 4336 & 1.48 & 0.05 & 11.98 & 1.48 & 0.07 & 7.94 \\
\hline
\end{tabular}


Table E1: Continued

\begin{tabular}{|c|c|c|c|c|c|c|}
\hline Midas & $\begin{array}{c}\text { Maximum } \\
\text { Precip } \\
\text { January }\end{array}$ & $\begin{array}{c}\text { Average } \\
\text { Precip } \\
\text { January }\end{array}$ & $\begin{array}{c}\text { Sum } \\
\text { Precip } \\
\text { January }\end{array}$ & $\begin{array}{c}\text { Maximum } \\
\text { Precip } \\
\text { May } \\
\end{array}$ & $\begin{array}{c}\text { Average } \\
\text { Precip } \\
\text { May } \\
\end{array}$ & $\begin{array}{c}\text { Sum } \\
\text { Precip } \\
\text { May } \\
\end{array}$ \\
\hline 4388 & 1.02 & 0.05 & 11.20 & 1.02 & 0.06 & 6.19 \\
\hline 4452 & 2.64 & 0.12 & 31.31 & 2.64 & 0.16 & 22.35 \\
\hline 4492 & 2.04 & 0.11 & 22.67 & 0.96 & 0.10 & 10.09 \\
\hline 4606 & 2.64 & 0.12 & 31.31 & 2.64 & 0.16 & 22.35 \\
\hline 4608 & 2.64 & 0.12 & 31.31 & 2.64 & 0.16 & 22.35 \\
\hline 4610 & 2.64 & 0.12 & 31.31 & 2.64 & 0.16 & 22.35 \\
\hline 4612 & 2.64 & 0.12 & 31.31 & 2.64 & 0.16 & 22.35 \\
\hline 4614 & 2.64 & 0.12 & 30.87 & 2.64 & 0.16 & 21.91 \\
\hline 4618 & 2.64 & 0.12 & 31.31 & 2.64 & 0.16 & 22.35 \\
\hline 4620 & 2.64 & 0.12 & 30.87 & 2.64 & 0.16 & 21.91 \\
\hline 4622 & 2.64 & 0.12 & 31.31 & 2.64 & 0.16 & 22.35 \\
\hline 4624 & 2.64 & 0.12 & 30.87 & 2.64 & 0.16 & 21.91 \\
\hline 4628 & 2.64 & 0.12 & 30.87 & 2.64 & 0.16 & 21.91 \\
\hline 4630 & 2.64 & 0.12 & 30.87 & 2.64 & 0.16 & 21.91 \\
\hline 4766 & 2.04 & 0.11 & 22.67 & 0.96 & 0.10 & 10.09 \\
\hline 4782 & 2.12 & 0.15 & 31.03 & 1.97 & 0.15 & 17.72 \\
\hline 4788 & 2.04 & 0.11 & 22.67 & 0.96 & 0.10 & 10.09 \\
\hline 4800 & 2.26 & 0.08 & 20.12 & 2.26 & 0.08 & 9.49 \\
\hline 4802 & 0.91 & 0.07 & 15.11 & 0.89 & 0.06 & 6.28 \\
\hline 4806 & 0.91 & 0.07 & 15.11 & 0.89 & 0.06 & 6.28 \\
\hline 4822 & 0.91 & 0.07 & 15.11 & 0.89 & 0.06 & 6.28 \\
\hline 4852 & 0.91 & 0.07 & 15.11 & 0.89 & 0.06 & 6.28 \\
\hline 4857 & 2.20 & 0.07 & 17.69 & 1.85 & 0.06 & 7.06 \\
\hline 4894 & 0.91 & 0.07 & 15.91 & 0.89 & 0.07 & 7.08 \\
\hline 4896 & 1.54 & 0.07 & 17.24 & 1.21 & 0.07 & 8.33 \\
\hline 5024 & 9.90 & 0.14 & 32.89 & 1.49 & 0.09 & 11.55 \\
\hline 5172 & 1.50 & 0.08 & 18.32 & 0.77 & 0.07 & 7.39 \\
\hline 5174 & 1.50 & 0.08 & 18.32 & 0.77 & 0.07 & 7.39 \\
\hline 5198 & 1.54 & 0.07 & 16.40 & 1.21 & 0.07 & 7.49 \\
\hline 5222 & 3.13 & 0.13 & 33.46 & 1.24 & 0.12 & 15.88 \\
\hline 5236 & 2.46 & 0.09 & 21.51 & 0.95 & 0.06 & 7.19 \\
\hline 5240 & 2.46 & 0.09 & 22.42 & 0.95 & 0.06 & 8.10 \\
\hline 5280 & 1.91 & 0.09 & 19.13 & 1.91 & 0.10 & 9.85 \\
\hline 5344 & 1.91 & 0.09 & 21.04 & 1.91 & 0.10 & 11.76 \\
\hline 5348 & 1.91 & 0.09 & 21.04 & 1.91 & 0.10 & 11.76 \\
\hline 5349 & 1.91 & 0.09 & 21.04 & 1.91 & 0.10 & 11.76 \\
\hline 5352 & 2.46 & 0.10 & 21.31 & 0.95 & 0.07 & 6.99 \\
\hline 5386 & 2.46 & 0.09 & 22.42 & 0.95 & 0.07 & 8.10 \\
\hline 5400 & 3.34 & 0.12 & 29.51 & 2.51 & 0.13 & 15.86 \\
\hline 5408 & 1.54 & 0.07 & 17.24 & 1.21 & 0.07 & 8.33 \\
\hline
\end{tabular}


Table E1: Continued

\begin{tabular}{|c|c|c|c|c|c|c|}
\hline Midas & $\begin{array}{c}\text { Maximum } \\
\text { Precip } \\
\text { January } \\
\end{array}$ & $\begin{array}{c}\text { Average } \\
\text { Precip } \\
\text { January }\end{array}$ & $\begin{array}{c}\text { Sum } \\
\text { Precip } \\
\text { January } \\
\end{array}$ & $\begin{array}{c}\text { Maximum } \\
\text { Precip } \\
\text { May } \\
\end{array}$ & $\begin{array}{c}\text { Average } \\
\text { Precip } \\
\text { May } \\
\end{array}$ & $\begin{array}{c}\text { Sum } \\
\text { Precip } \\
\text { May } \\
\end{array}$ \\
\hline 5416 & 1.54 & 0.07 & 17.24 & 1.21 & 0.07 & 8.33 \\
\hline 5448 & 1.54 & 0.07 & 17.24 & 1.21 & 0.07 & 8.33 \\
\hline 5458 & 1.54 & 0.07 & 17.24 & 1.21 & 0.07 & 8.33 \\
\hline 5490 & 2.12 & 0.14 & 25.19 & 1.39 & 0.13 & 11.88 \\
\hline 5682 & 2.26 & 0.08 & 20.12 & 2.26 & 0.08 & 9.49 \\
\hline 5690 & 0.91 & 0.07 & 15.91 & 0.89 & 0.07 & 7.08 \\
\hline 5710 & 3.13 & 0.13 & 30.27 & 1.24 & 0.12 & 12.69 \\
\hline 5780 & 4.63 & 0.14 & 34.91 & 4.63 & 0.15 & 18.36 \\
\hline 5814 & 1.91 & 0.09 & 20.63 & 1.91 & 0.10 & 11.35 \\
\hline 9685 & 1.89 & 0.13 & 29.19 & 1.61 & 0.12 & 12.64 \\
\hline 9931 & 2.46 & 0.09 & 22.42 & 0.95 & 0.07 & 8.10 \\
\hline \multicolumn{7}{|l|}{ LEA } \\
\hline 5780 & 1.05 & 0.10 & 19.01 & 1.05 & 0.17 & 11.99 \\
\hline 3418 & 1.05 & 0.08 & 14.22 & 1.05 & 0.15 & 7.20 \\
\hline 5780 & 1.05 & 0.10 & 19.01 & 1.05 & 0.17 & 11.99 \\
\hline 3130 & 1.05 & 0.10 & 19.25 & 1.05 & 0.15 & 12.23 \\
\hline 3382 & 1.05 & 0.09 & 18.04 & 1.05 & 0.16 & 11.02 \\
\hline 3424 & 1.05 & 0.09 & 17.38 & 1.05 & 0.16 & 10.36 \\
\hline 3199 & 1.05 & 0.10 & 19.02 & 1.05 & 0.16 & 12.00 \\
\hline 3134 & 1.05 & 0.09 & 15.39 & 1.05 & 0.14 & 8.37 \\
\hline 3416 & 1.05 & 0.08 & 14.22 & 1.05 & 0.15 & 7.20 \\
\hline 9685 & 1.05 & 0.10 & 19.01 & 1.05 & 0.17 & 11.99 \\
\hline 3420 & 1.05 & 0.10 & 19.18 & 1.05 & 0.16 & 12.16 \\
\hline 3454 & 1.05 & 0.09 & 16.90 & 1.05 & 0.16 & 9.88 \\
\hline 5582 & 2.15 & 0.11 & 25.65 & 2.15 & 0.16 & 18.63 \\
\hline 3134 & 1.05 & 0.09 & 15.39 & 1.05 & 0.14 & 8.37 \\
\hline 5780 & 1.05 & 0.10 & 19.01 & 1.05 & 0.17 & 11.99 \\
\hline 5780 & 1.05 & 0.10 & 19.01 & 1.05 & 0.17 & 11.99 \\
\hline 3132 & 1.05 & 0.10 & 19.25 & 1.05 & 0.15 & 12.23 \\
\hline 3126 & 1.05 & 0.10 & 19.25 & 1.05 & 0.15 & 12.23 \\
\hline 3234 & 1.05 & 0.09 & 16.90 & 1.05 & 0.16 & 9.88 \\
\hline 3374 & 1.89 & 0.14 & 24.90 & 1.61 & 0.15 & 8.35 \\
\hline 3134 & 1.05 & 0.09 & 15.39 & 1.05 & 0.14 & 8.37 \\
\hline 3452 & 2.04 & 0.10 & 21.68 & 2.04 & 0.16 & 14.66 \\
\hline 3454 & 1.05 & 0.09 & 16.90 & 1.05 & 0.16 & 9.88 \\
\hline 3448 & 2.04 & 0.10 & 21.71 & 2.04 & 0.16 & 14.69 \\
\hline 3232 & 1.05 & 0.10 & 19.02 & 1.05 & 0.16 & 12.00 \\
\hline 3456 & 2.15 & 0.11 & 28.25 & 2.15 & 0.16 & 21.23 \\
\hline 5780 & 1.05 & 0.10 & 19.01 & 1.05 & 0.17 & 11.99 \\
\hline
\end{tabular}




\section{APPENDIX F: FIELD MAPS AND LOCATION}



Figure F1: Map of All Study Sites (2015 + DEP + LEA). 
Table F1: Latitude and Longitude of Sample Sites.

\begin{tabular}{|c|c|c|}
\hline Midas & Latitude & Longitude \\
\hline \multicolumn{3}{|l|}{2015} \\
\hline 78 & 44.93002 & -69.94942 \\
\hline 177 & 45.07812 & -67.39989 \\
\hline 224 & 45.00000 & -70.00000 \\
\hline 3444 & 44.08828 & -70.49226 \\
\hline 3446 & 44.02313 & -70.51890 \\
\hline 3748 & 44.15484 & -70.24572 \\
\hline 3750 & 44.10937 & -70.27902 \\
\hline 3796 & 44.15569 & -70.10254 \\
\hline 3838 & 43.51829 & -70.86478 \\
\hline 3916 & 43.56730 & -70.88877 \\
\hline 4434 & 44.59309 & -68.06811 \\
\hline 4538 & 44.78949 & -68.45292 \\
\hline 5172 & 44.63267 & -69.33733 \\
\hline 5190 & 44.72568 & -70.08022 \\
\hline 5272 & 44.53087 & -69.86854 \\
\hline 5274 & 44.54562 & -69.85496 \\
\hline 5280 & 44.48882 & -69.78232 \\
\hline 5344 & 44.62965 & -69.83641 \\
\hline 5348 & 44.56619 & -69.76167 \\
\hline 5349 & 44.61267 & -69.77957 \\
\hline 5352 & 44.52060 & -69.78636 \\
\hline 5400 & 44.17599 & -69.47588 \\
\hline 5408 & 44.40474 & -69.65847 \\
\hline 5448 & 44.43288 & -69.56964 \\
\hline \multicolumn{3}{|l|}{2016} \\
\hline 3688 & NA & NA \\
\hline 3760 & NA & NA \\
\hline 3762 & NA & NA \\
\hline 3824 & NA & NA \\
\hline 3826 & NA & NA \\
\hline 4346 & NA & NA \\
\hline 4406 & NA & NA \\
\hline 4444 & NA & NA \\
\hline 4446 & NA & NA \\
\hline 4448 & NA & NA \\
\hline 5182 & NA & NA \\
\hline 5184 & NA & NA \\
\hline 5186 & NA & NA \\
\hline 5330 & NA & NA \\
\hline
\end{tabular}

\begin{tabular}{|c|c|c|}
\hline Midas & Latitude & Longitude \\
\hline 5664 & NA & NA \\
\hline 5666 & NA & NA \\
\hline 5812 & NA & NA \\
\hline 5814 & NA & NA \\
\hline \multicolumn{3}{|l|}{ DEP } \\
\hline 70 & 44.82877 & -69.76435 \\
\hline 80 & 44.93207 & -68.79489 \\
\hline 121 & 45.66648 & -67.70291 \\
\hline 177 & 45.07812 & -67.39989 \\
\hline 243 & 45.59662 & -68.95802 \\
\hline 262 & 45.10805 & -69.65791 \\
\hline 342 & 45.47348 & -69.52521 \\
\hline 386 & 45.47587 & -69.55603 \\
\hline 410 & 45.49611 & -69.49409 \\
\hline 447 & 44.29894 & -68.25668 \\
\hline 760 & 45.12637 & -69.29940 \\
\hline 954 & 45.46331 & -68.88313 \\
\hline 1068 & 45.74734 & -67.85553 \\
\hline 1070 & 45.67799 & -67.80356 \\
\hline 1078 & 45.50793 & -67.83540 \\
\hline 1088 & 45.40693 & -67.79702 \\
\hline 1150 & 45.23427 & -67.79879 \\
\hline 1210 & 44.85740 & -67.98280 \\
\hline 2004 & 45.52415 & -68.80660 \\
\hline 2020 & 45.77675 & -68.81272 \\
\hline 2146 & 45.28556 & -68.52398 \\
\hline 2156 & 45.01694 & -68.93648 \\
\hline 2242 & 45.34826 & -68.31377 \\
\hline 2286 & 44.78071 & -68.93905 \\
\hline 2590 & 44.91318 & -69.54601 \\
\hline 2608 & 44.77748 & -69.58460 \\
\hline 2948 & 45.86571 & -69.54524 \\
\hline 3038 & 45.65983 & -68.30424 \\
\hline 3376 & 43.93071 & -70.65781 \\
\hline 3388 & 43.99273 & -70.51502 \\
\hline 3434 & 44.21469 & -70.57212 \\
\hline 3452 & 44.12538 & -70.67132 \\
\hline 3454 & 44.07050 & -70.73411 \\
\hline 3604 & 44.42017 & -70.32136 \\
\hline 3626 & 44.28232 & -70.26900 \\
\hline
\end{tabular}


Table F1: Continued

\begin{tabular}{|c|c|c|}
\hline Midas & Latitude & Longitude \\
\hline 3672 & 44.69500 & -70.45172 \\
\hline 3682 & 44.59583 & -70.24938 \\
\hline 3690 & 43.96946 & -70.42401 \\
\hline 3780 & 44.21894 & -70.45704 \\
\hline 3814 & 44.23103 & -70.04435 \\
\hline 3830 & 44.32020 & -70.02988 \\
\hline 3884 & 43.25595 & -70.76232 \\
\hline 3920 & 43.55762 & -70.93620 \\
\hline 4272 & 44.81475 & -68.49757 \\
\hline 4316 & 44.65675 & -68.68365 \\
\hline 4322 & 44.64470 & -68.74536 \\
\hline 4328 & 44.61419 & -68.57198 \\
\hline 4330 & 44.58874 & -68.59670 \\
\hline 4336 & 44.57581 & -68.69672 \\
\hline 4388 & 44.55192 & -68.13376 \\
\hline 4452 & 44.34430 & -68.23855 \\
\hline 4492 & 44.89641 & -68.22517 \\
\hline 4606 & 44.35513 & -68.25176 \\
\hline 4608 & 44.33324 & -68.25525 \\
\hline 4610 & 44.30990 & -68.28992 \\
\hline 4612 & 44.32108 & -68.28691 \\
\hline 4614 & 44.35924 & -68.34562 \\
\hline 4618 & 44.36727 & -68.36428 \\
\hline 4620 & 44.35327 & -68.37781 \\
\hline 4622 & 44.31439 & -68.35458 \\
\hline 4624 & 44.32178 & -68.33580 \\
\hline 4628 & 44.32342 & -68.39736 \\
\hline 4630 & 44.30321 & -68.39634 \\
\hline 4766 & 45.05844 & -68.13756 \\
\hline 4782 & 45.10444 & -68.07240 \\
\hline 4788 & 45.02014 & -68.06924 \\
\hline 4800 & 44.21615 & -69.21109 \\
\hline 4802 & 44.22625 & -69.18520 \\
\hline 4806 & 44.24334 & -69.17352 \\
\hline 4822 & 44.14192 & -69.11361 \\
\hline 4852 & 44.24426 & -69.11061 \\
\hline 4857 & 43.98933 & -69.44760 \\
\hline 4894 & 44.29221 & -69.36783 \\
\hline 4896 & 44.35873 & -69.43467 \\
\hline 5024 & 43.59641 & -70.70685 \\
\hline 5172 & 44.63267 & -69.33733 \\
\hline
\end{tabular}

\begin{tabular}{|c|c|c|}
\hline Midas & Latitude & Longitude \\
\hline 5174 & 44.51508 & -69.30497 \\
\hline 5198 & 44.59711 & -70.17640 \\
\hline 5222 & 43.95073 & -69.77071 \\
\hline 5236 & 44.25087 & -69.94375 \\
\hline 5240 & 44.19493 & -69.95101 \\
\hline 5280 & 44.48883 & -69.78232 \\
\hline 5344 & 44.62965 & -69.83641 \\
\hline 5348 & 44.56619 & -69.76167 \\
\hline 5349 & 44.61267 & -69.77957 \\
\hline 5352 & 44.52060 & -69.78636 \\
\hline 5386 & 44.18584 & -69.52181 \\
\hline 5400 & 44.17599 & -69.47588 \\
\hline 5408 & 44.40474 & -69.65847 \\
\hline 5416 & 44.36676 & -69.60731 \\
\hline 5448 & 44.43288 & -69.56964 \\
\hline 5458 & 44.53130 & -69.56234 \\
\hline 5490 & 44.54176 & -69.05426 \\
\hline 5682 & 44.25629 & -69.26632 \\
\hline 5690 & 44.13116 & -69.28700 \\
\hline 5710 & 44.01432 & -69.46965 \\
\hline 5780 & 44.08275 & -70.68175 \\
\hline 5814 & 44.43398 & -70.03114 \\
\hline 9685 & 43.95480 & -70.59010 \\
\hline 9931 & 44.32389 & -69.65798 \\
\hline \multicolumn{3}{|l|}{ LEA } \\
\hline 5780 & 44.06975 & -70.66750 \\
\hline 3418 & 44.18403 & -70.67667 \\
\hline 5780 & 44.02114 & -70.64778 \\
\hline 3130 & 43.95325 & -70.76694 \\
\hline 3382 & 43.93469 & -70.60722 \\
\hline 3424 & 44.13481 & -70.73528 \\
\hline 3199 & 44.21000 & -70.81417 \\
\hline 3134 & 44.06583 & -70.81028 \\
\hline 3416 & 44.17519 & -70.71083 \\
\hline 9685 & 43.95642 & -70.59083 \\
\hline 3420 & 44.15308 & -70.71778 \\
\hline 3454 & 44.09300 & -70.74472 \\
\hline 5582 & 44.06584 & -70.77170 \\
\hline 3134 & 44.05014 & -70.79889 \\
\hline 5780 & 44.08636 & -70.68500 \\
\hline 5780 & 43.98719 & -70.61750 \\
\hline
\end{tabular}


Table F1: Continued

\begin{tabular}{|ccc|}
\hline Midas & Latitude & Longitude \\
\hline 3132 & 43.94147 & -70.74667 \\
3126 & 43.95422 & -70.78556 \\
3234 & 44.11925 & 70.77667 \\
3374 & 43.94061 & -70.69417 \\
3134 & 44.00056 & -70.79556
\end{tabular}

\begin{tabular}{|ccc|}
\hline Midas & Latitude & Longitude \\
\hline 3452 & 44.12367 & -70.67361 \\
3454 & 44.06886 & 70.73333 \\
3448 & 44.15933 & -70.64250 \\
3232 & 44.14508 & -70.82111 \\
3456 & 44.03353 & -70.73500 \\
5780 & 44.08636 & -70.68500 \\
\hline
\end{tabular}


Figure F2: The Land cover Type for the 2015 Study Sites.

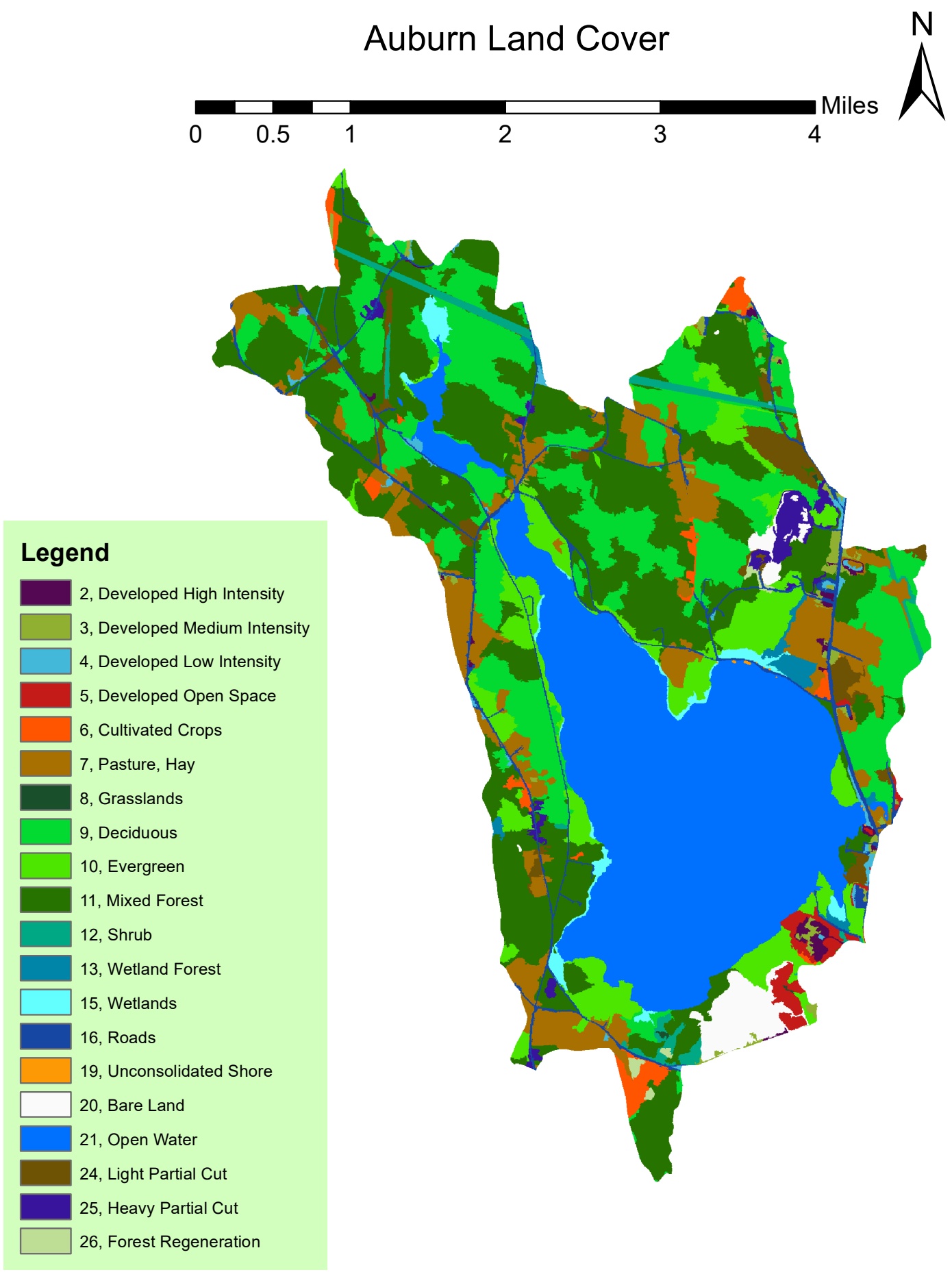


Figure F2: Continued

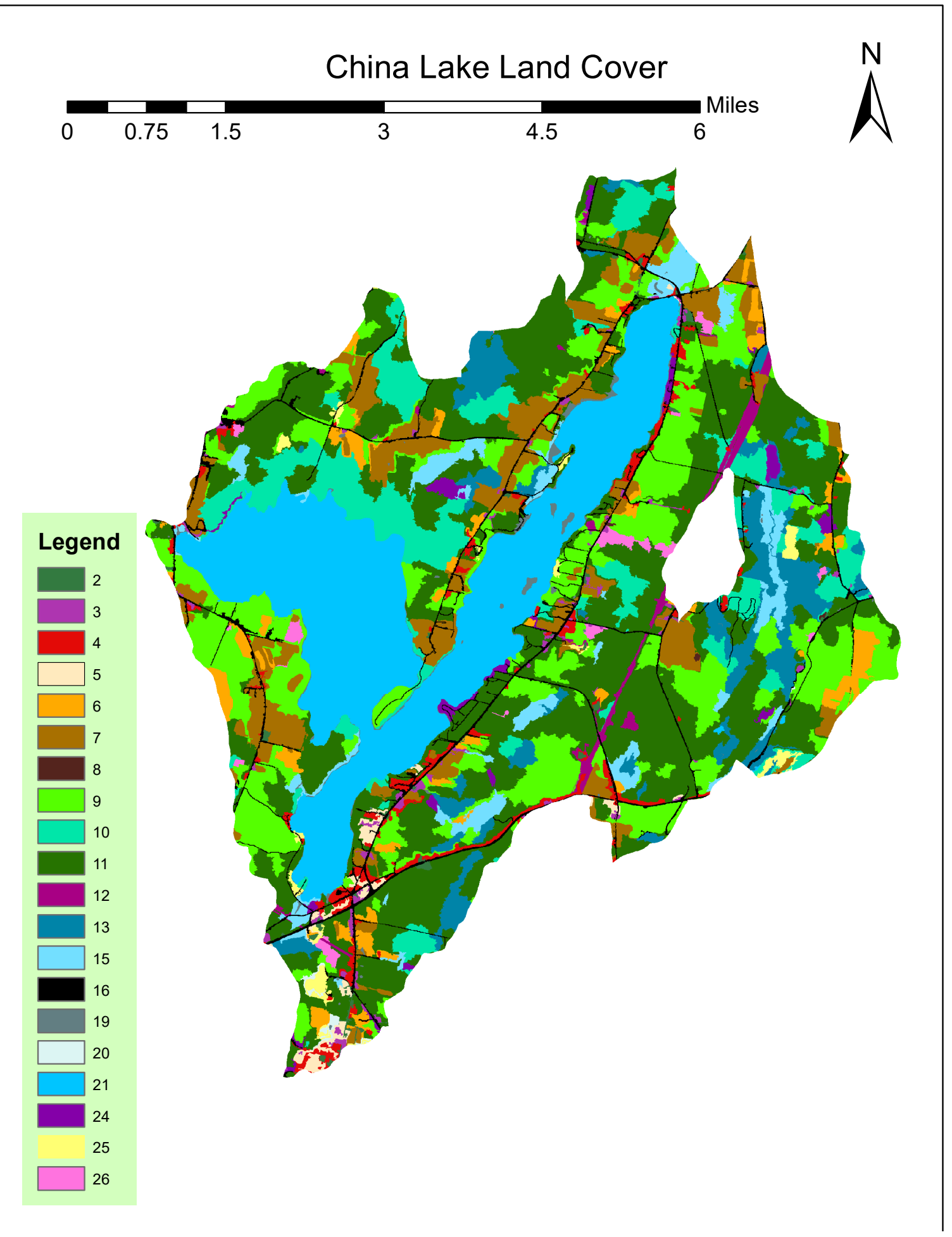


Figure F2: Continued

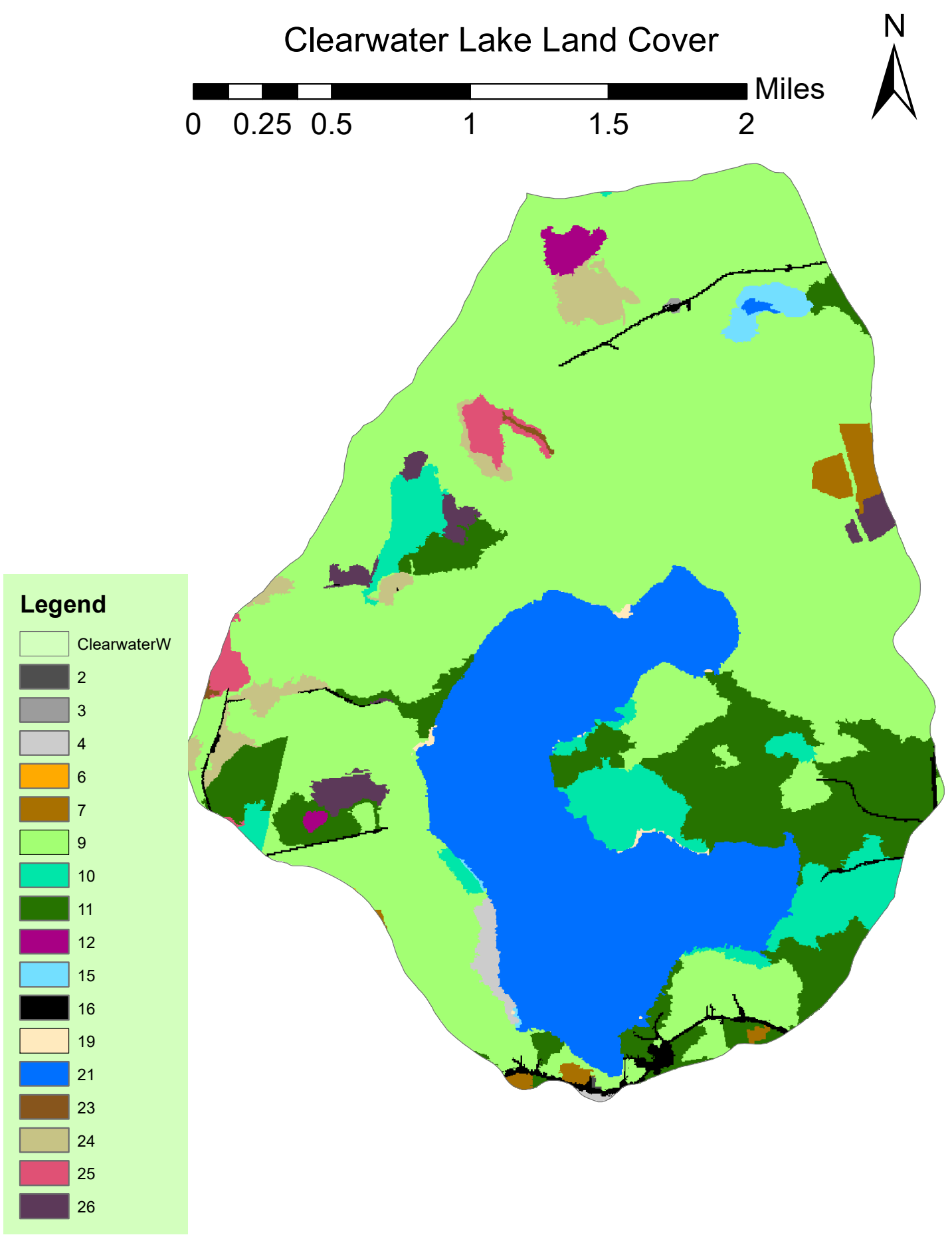


Figure F2: Continued




Figure F2: Continued

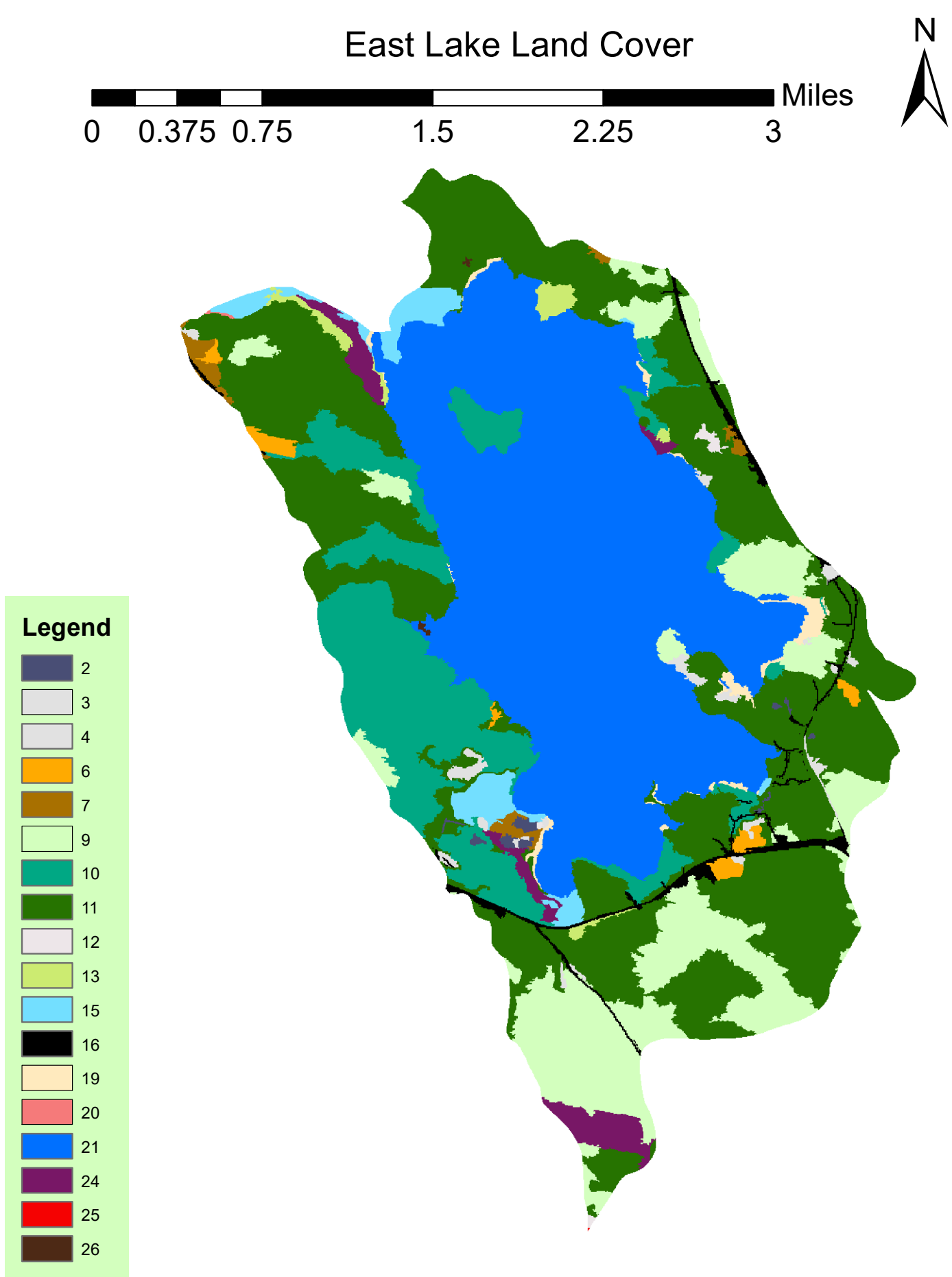


Figure F2: Continued

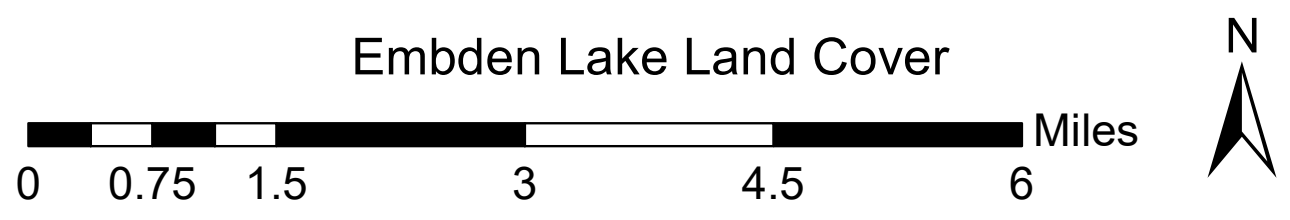

\section{Legend}

$\square$ EmbdenW

(2)

$\square$

$\square$

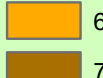

9

10

12

13

$\square 15$

16

$\square 19$

$\square$
2

23

24

25

26

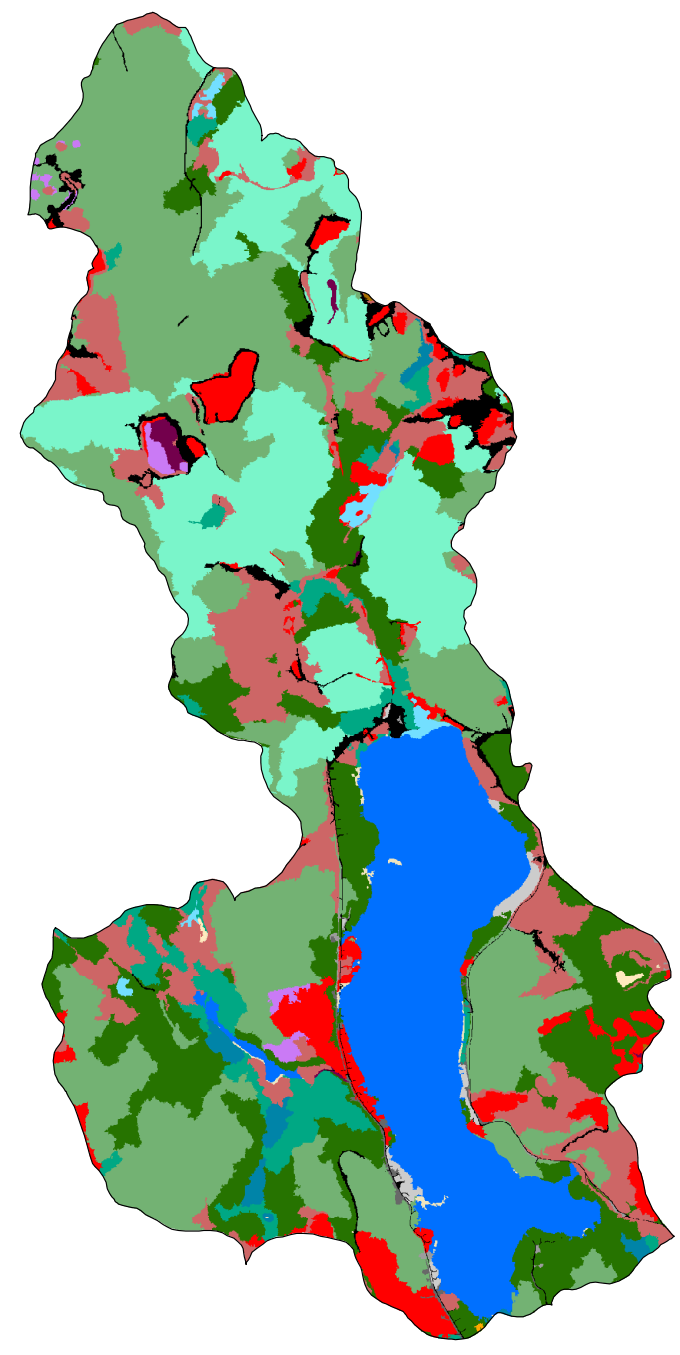


Figure F2: Continued

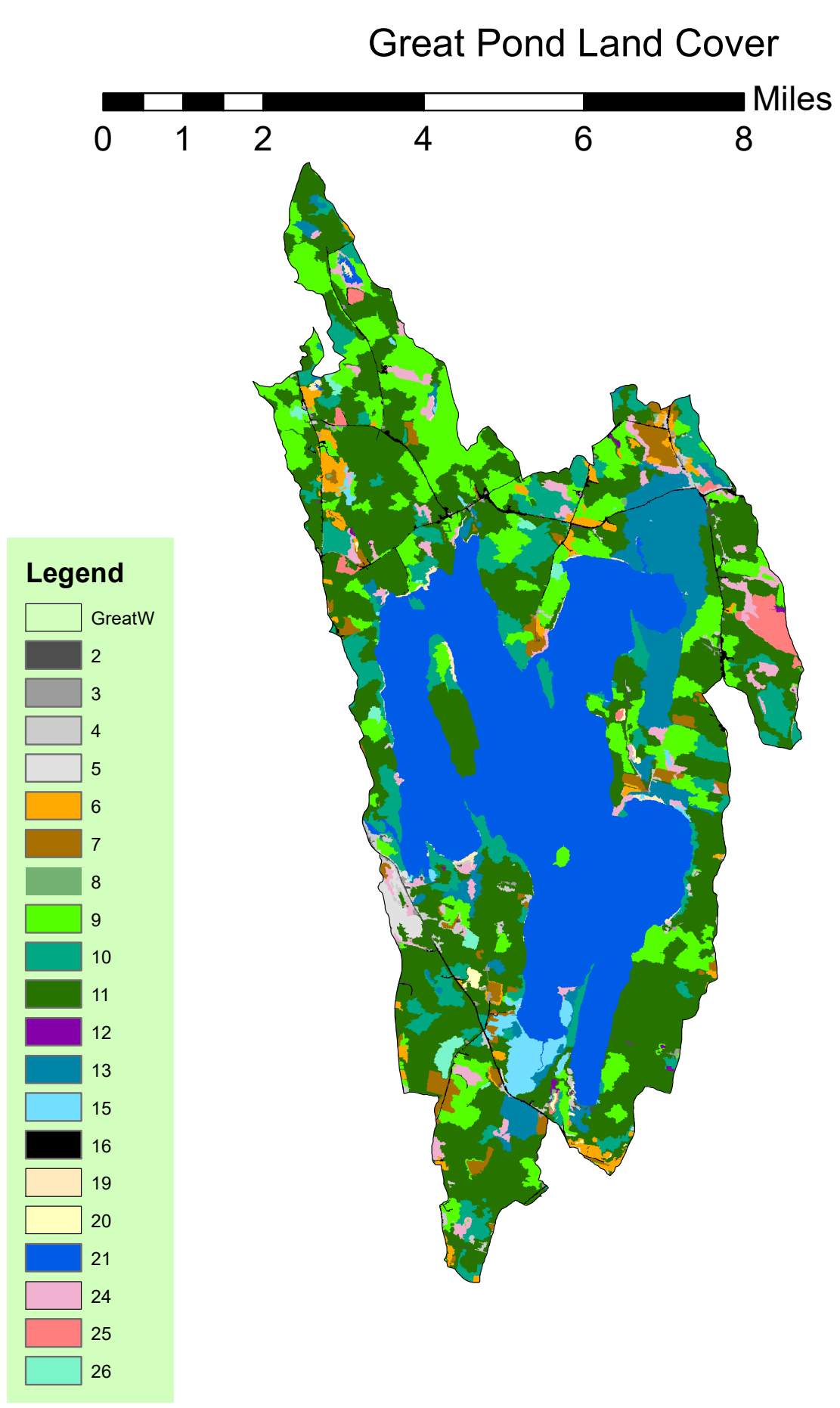


Figure F2: Continued

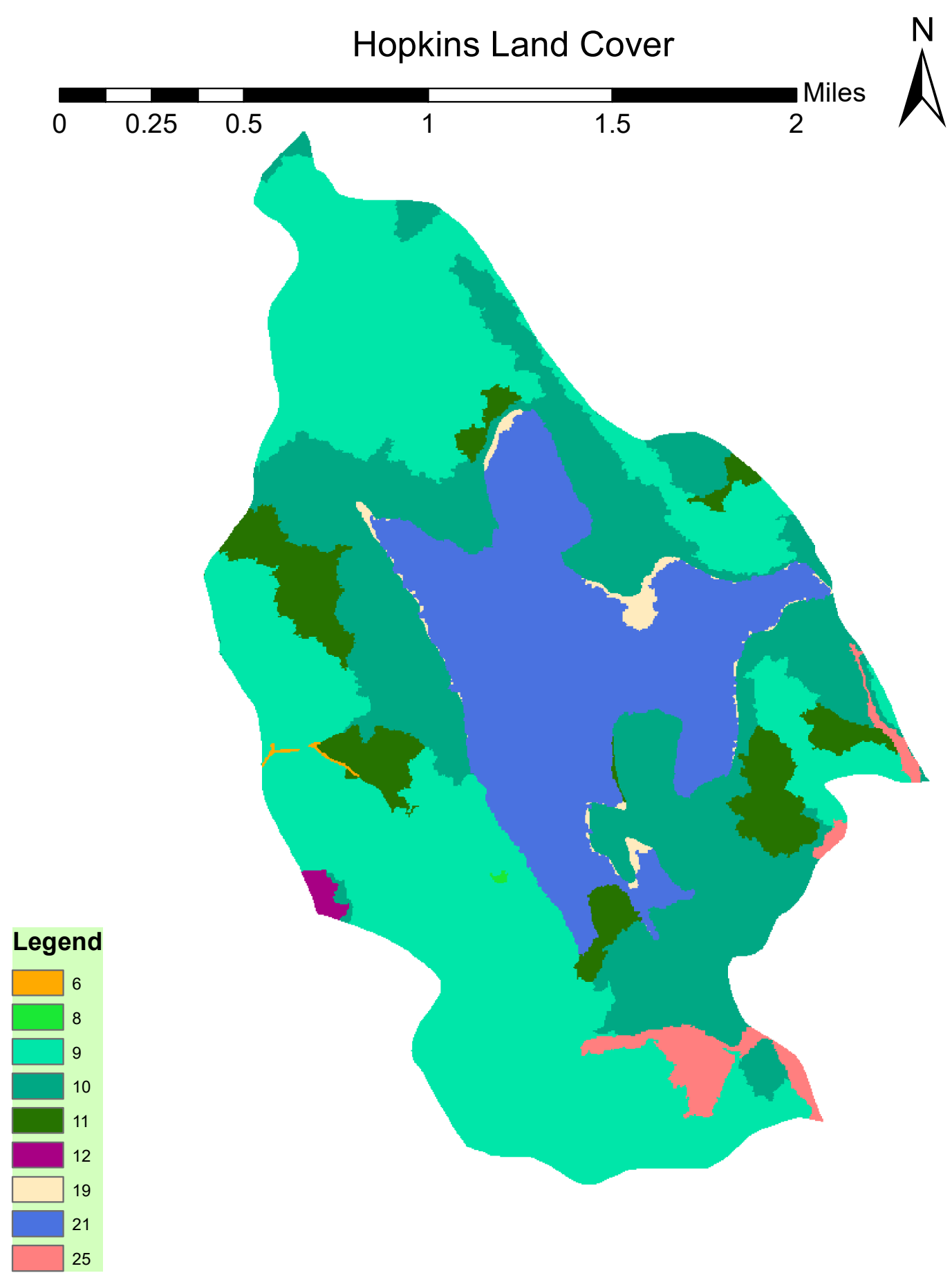


Figure F2: Continued

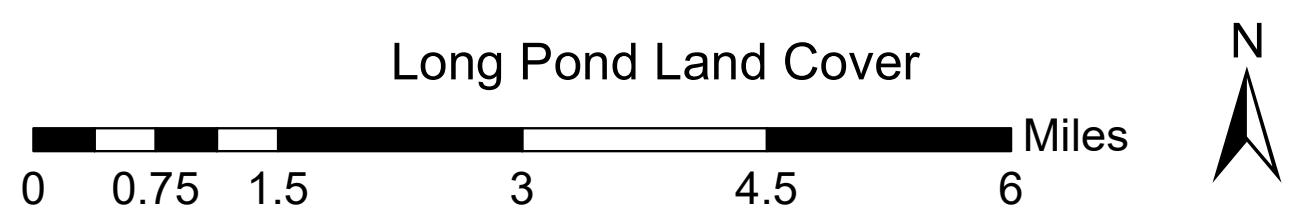

\section{Legend}

Longw 2

3

$\square$
$\square$
$\square$

6
7

7
$\quad 9$

10

11

12

13

\begin{tabular}{|l}
$\square$ \\
$\square$
\end{tabular}

16

$\square 19$

21

$\square 24$

25

26

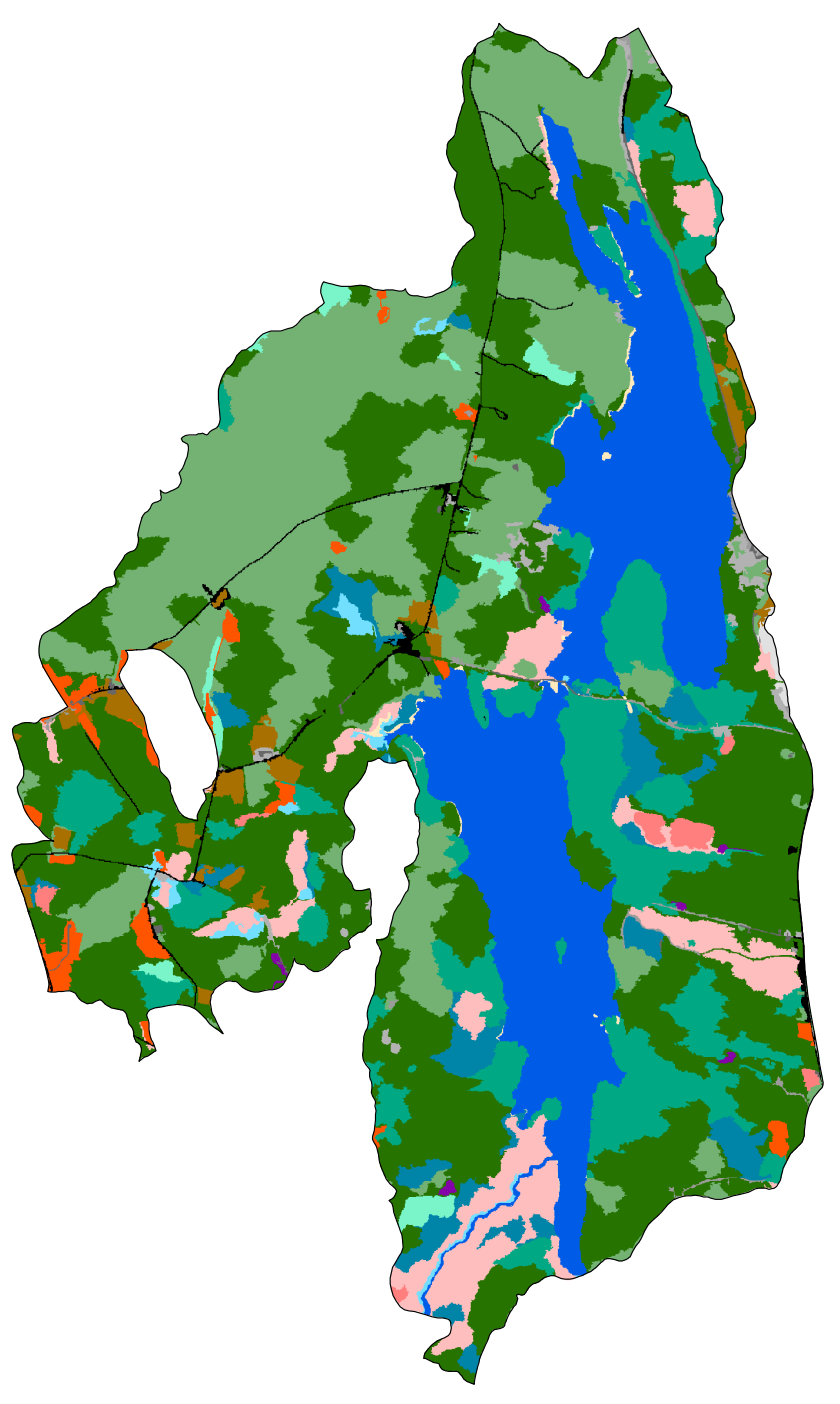


Figure F2: Continued

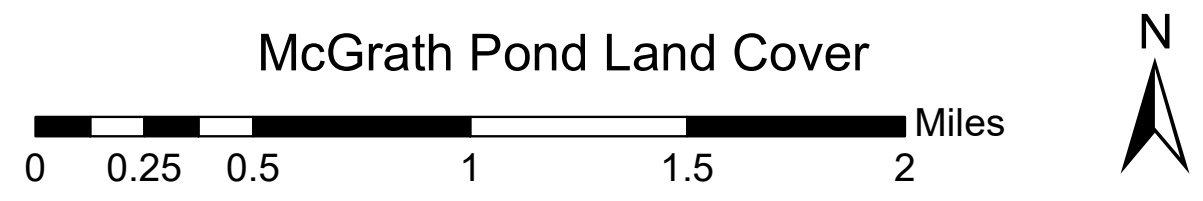

\section{Legend}

$\square$ McGrathW 2

3

$\square$
$\square$

$\square$

7

$\square$
$\square \quad 9$

10

11

12

13

15

16

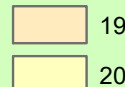

21

$\square 24$

25

26

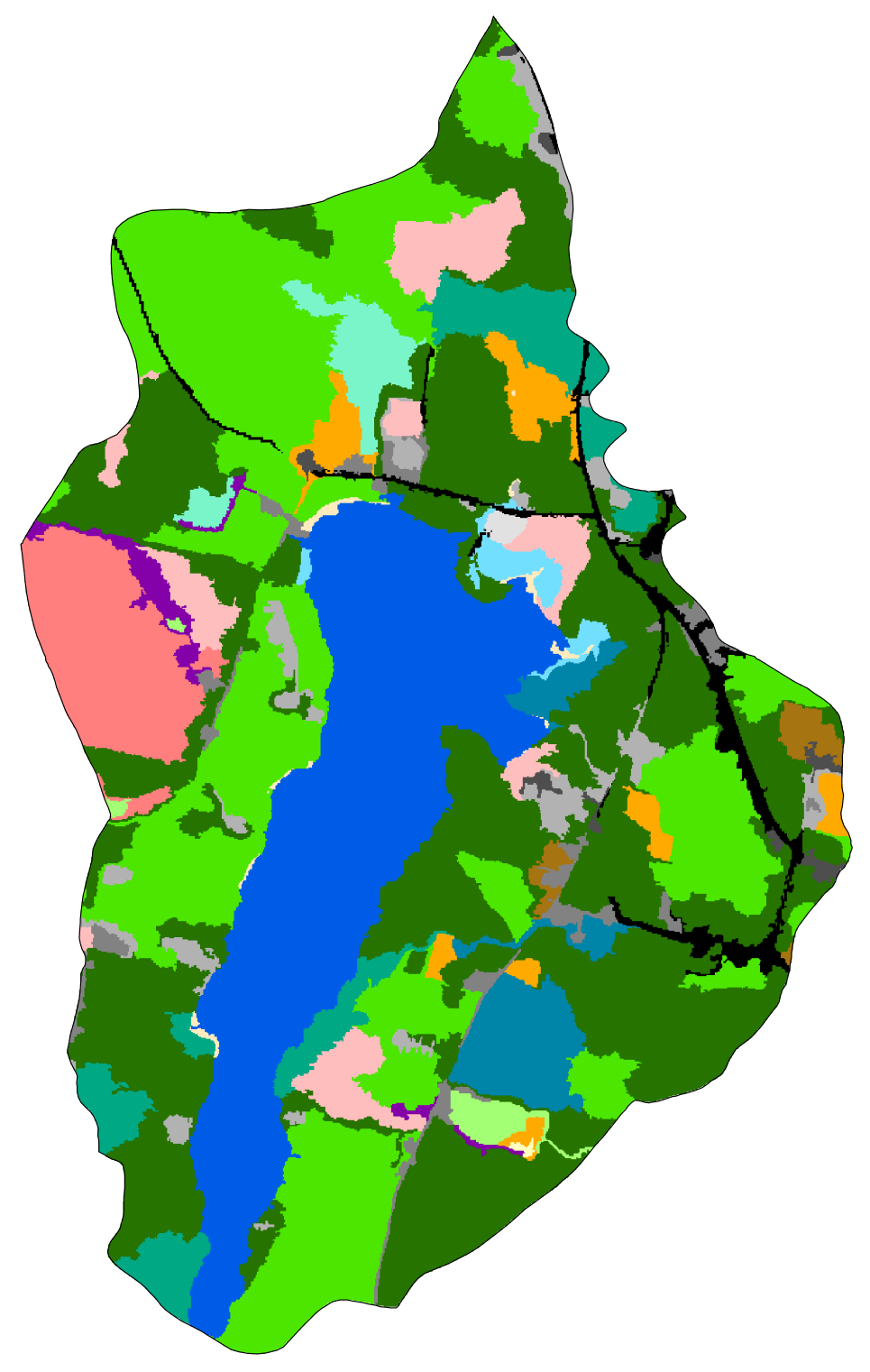


Figure F2: Continued

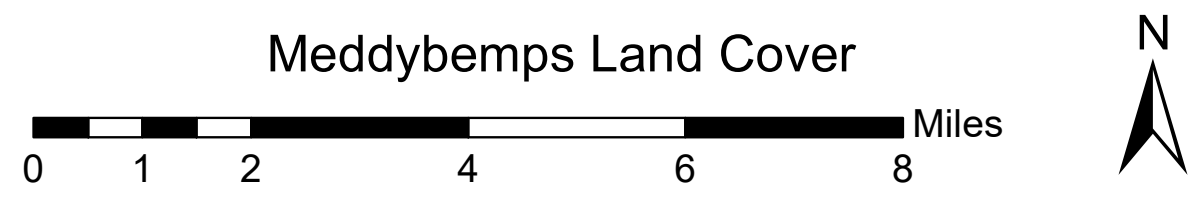

\section{Legend}

$\square$ Meddyw

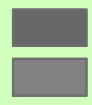

3

$\square$
$\square$
$\square$

$\square$
$\square$

7
$\square \quad 9$

$\square$
$\square$

11

12

13

15

16

$\begin{array}{r}\square \\ \square \\ \hline \square\end{array}$

21

22

23

24

$\square 25$

26 
Figure F2: Continued
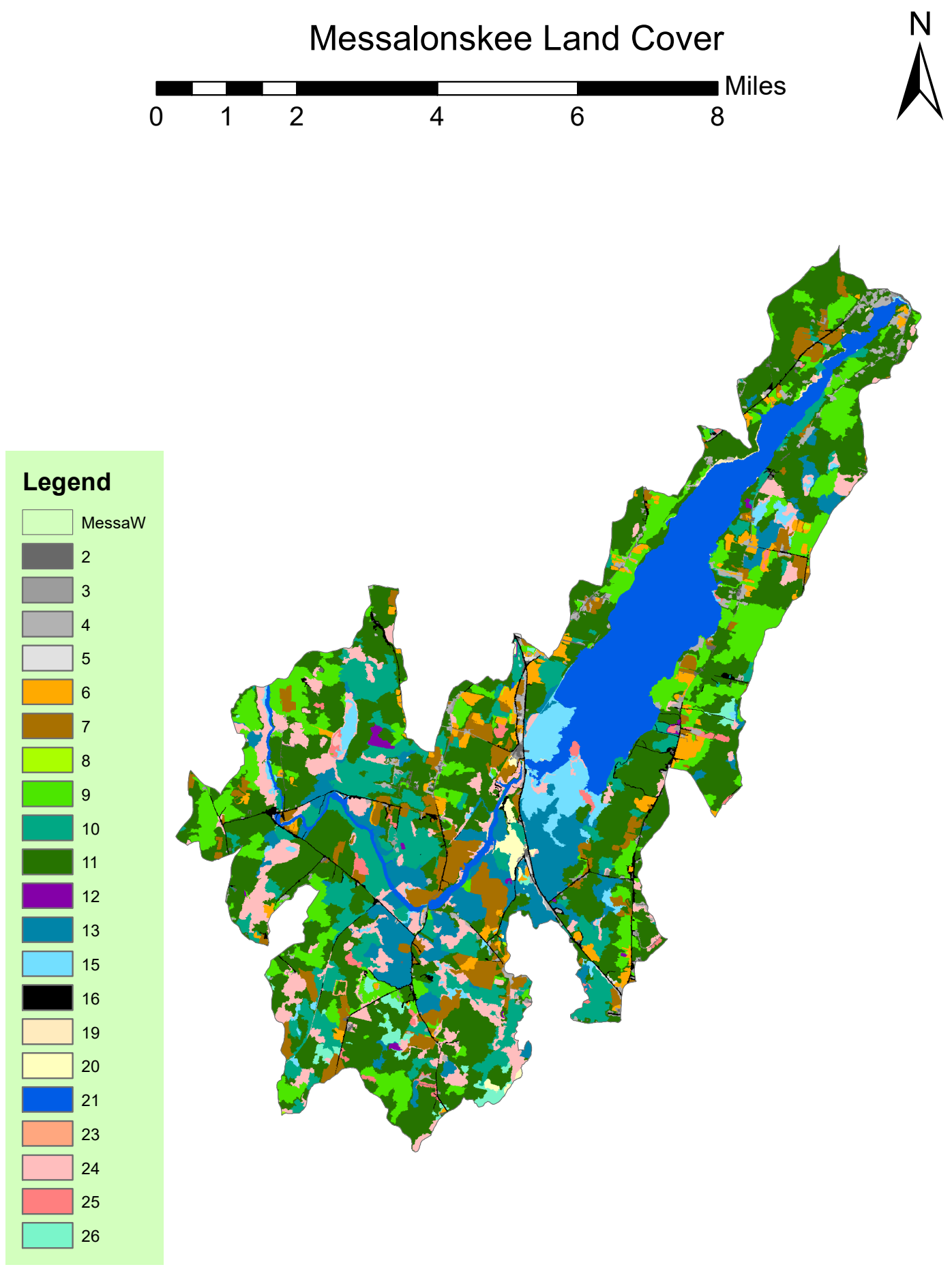
Figure F2: Continued
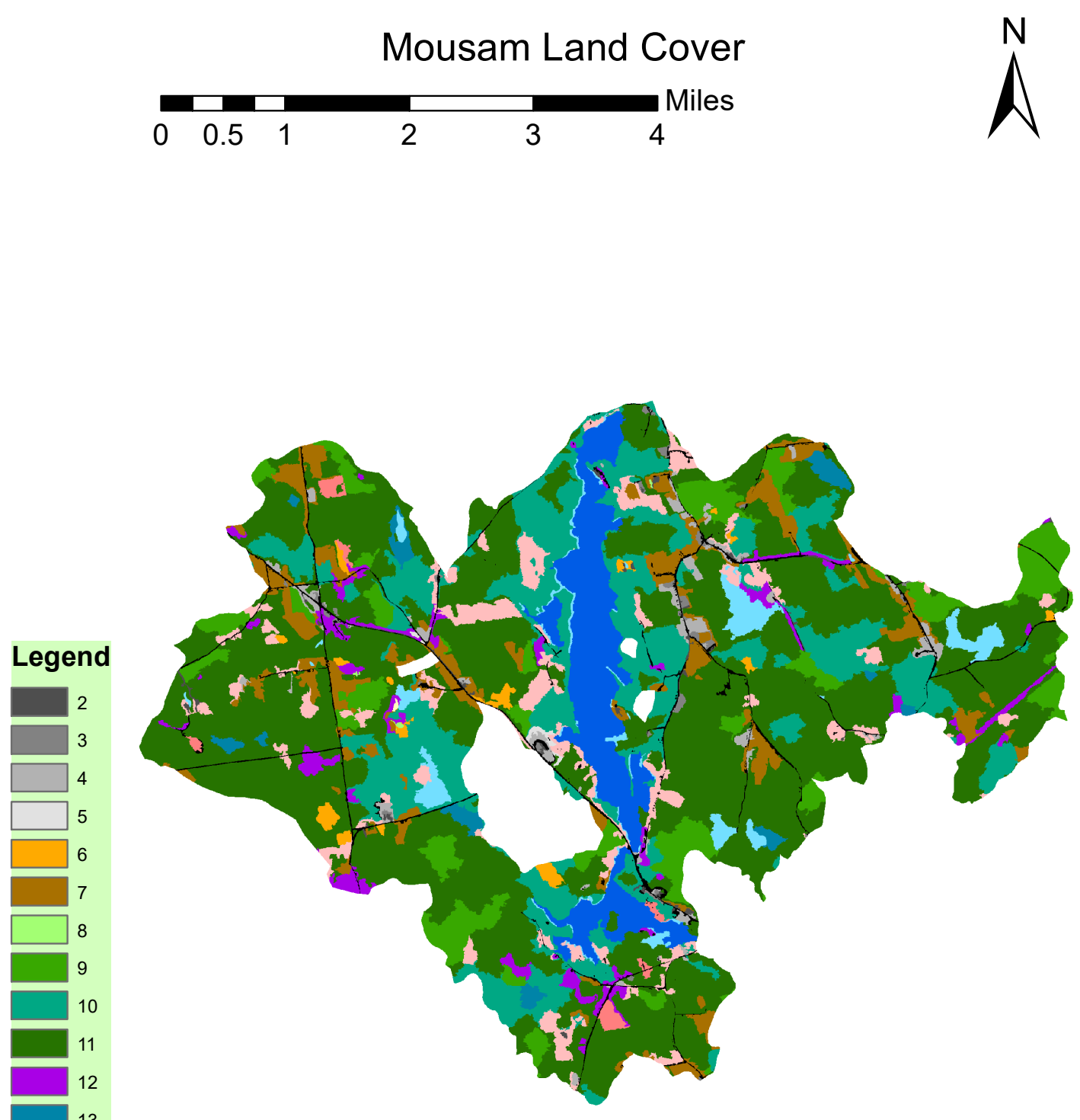
Figure F2: Continued

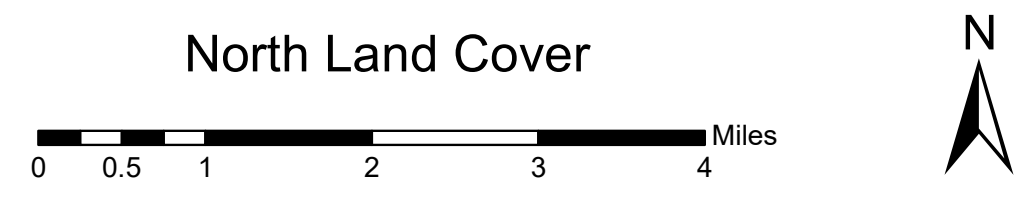

\section{Legend}

2

3

$\square$
$\square$

\begin{tabular}{|l|}
\hline \\
$\square$ \\
$\square \quad 9$ \\
\hline$\quad 10$
\end{tabular}

$\square$
$\square$
$\square$

12

\begin{tabular}{r}
\hline 13 \\
$\square \quad 15$
\end{tabular}

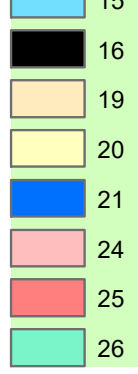

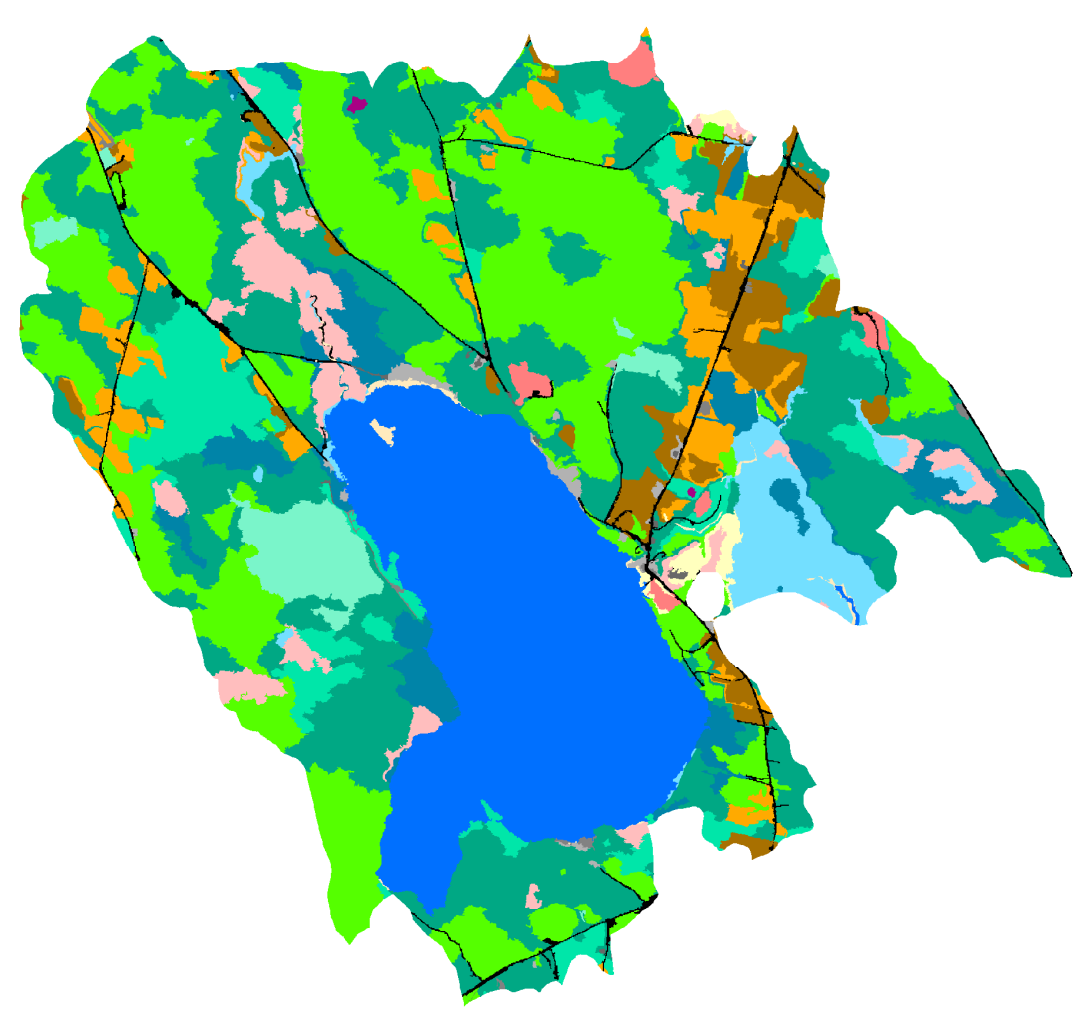


Figure F2: Continued

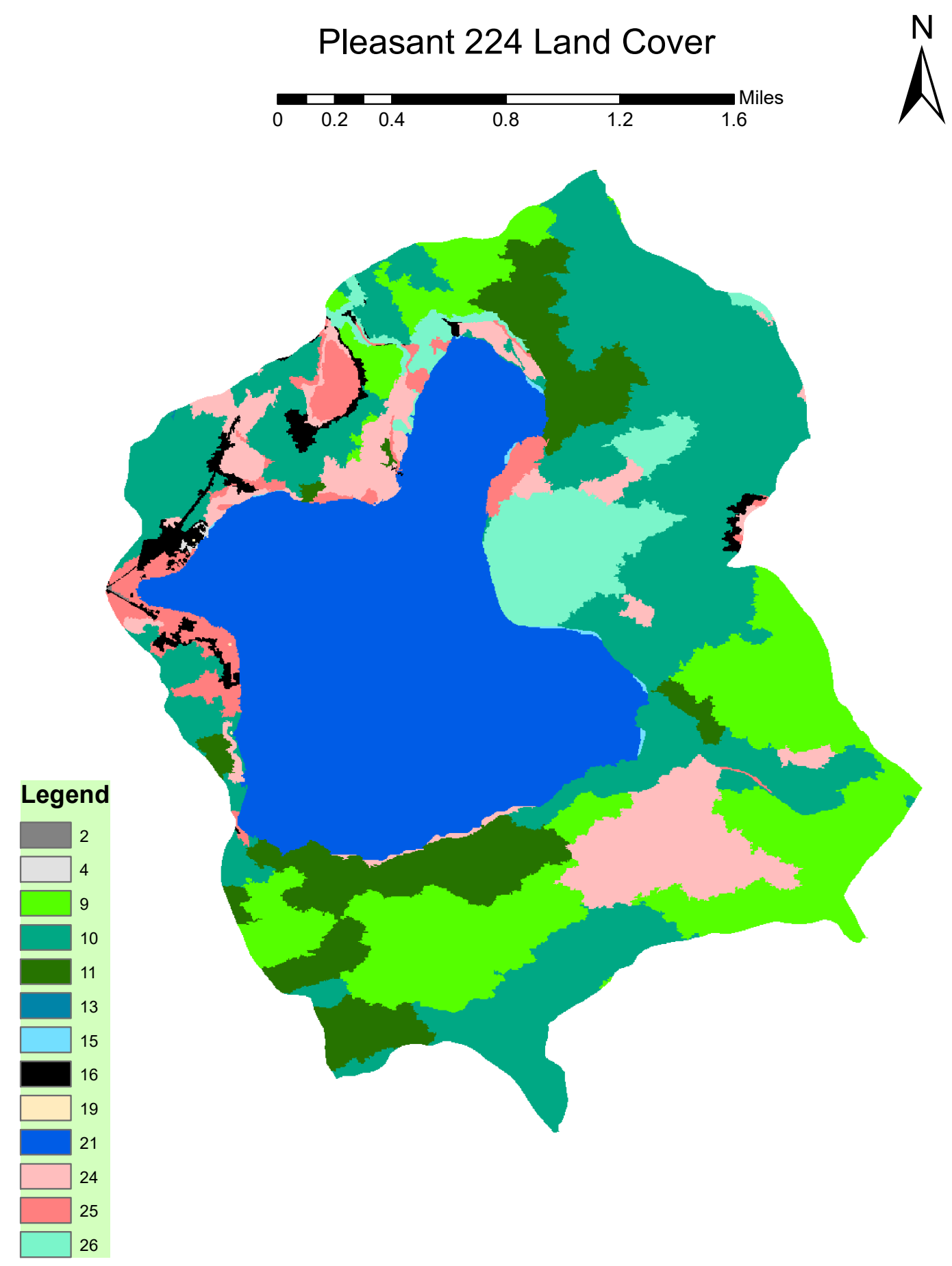


Figure F2: Continued

\section{Pleasant Casco Land Cover}

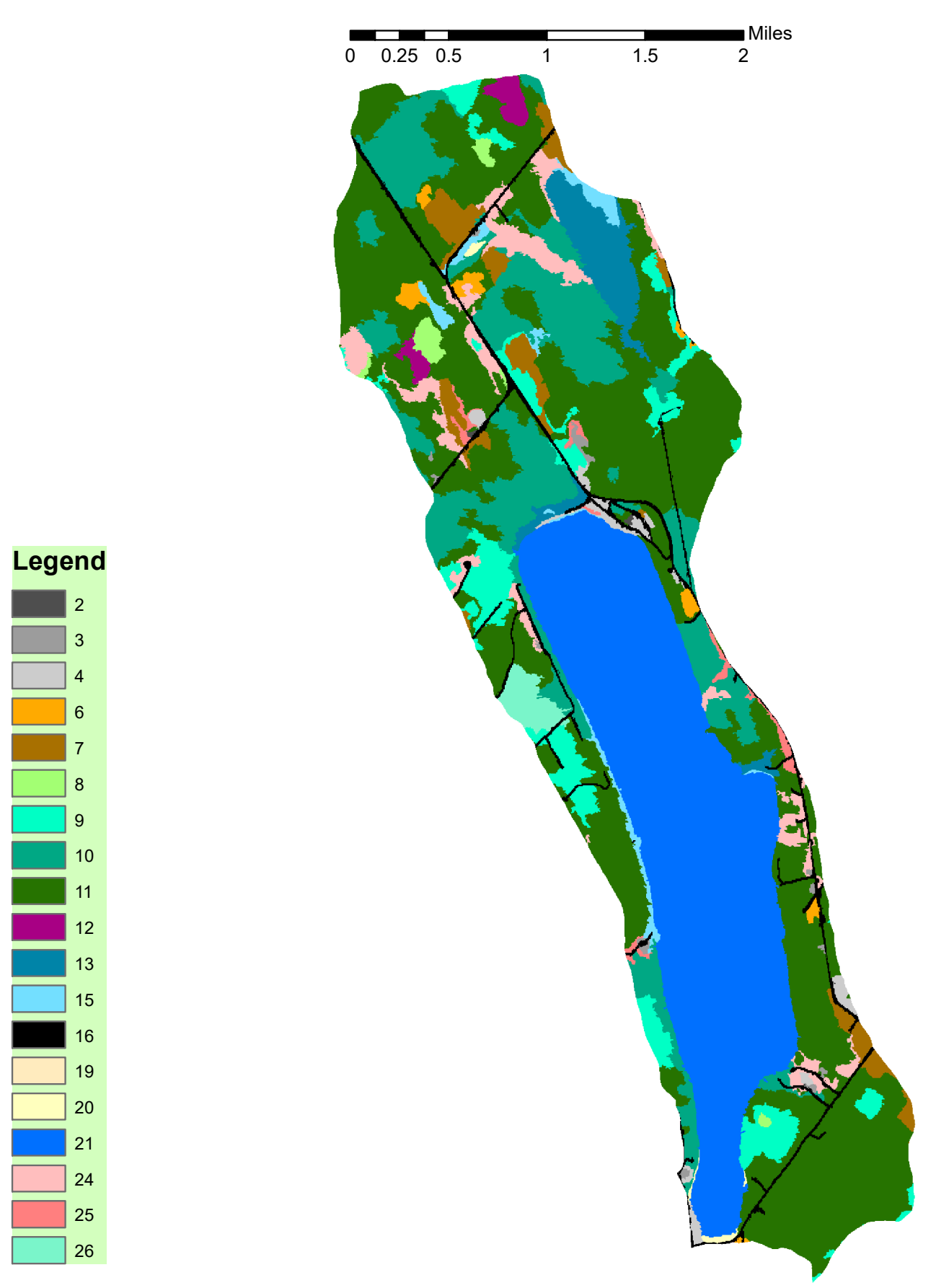


Figure F2: Continued

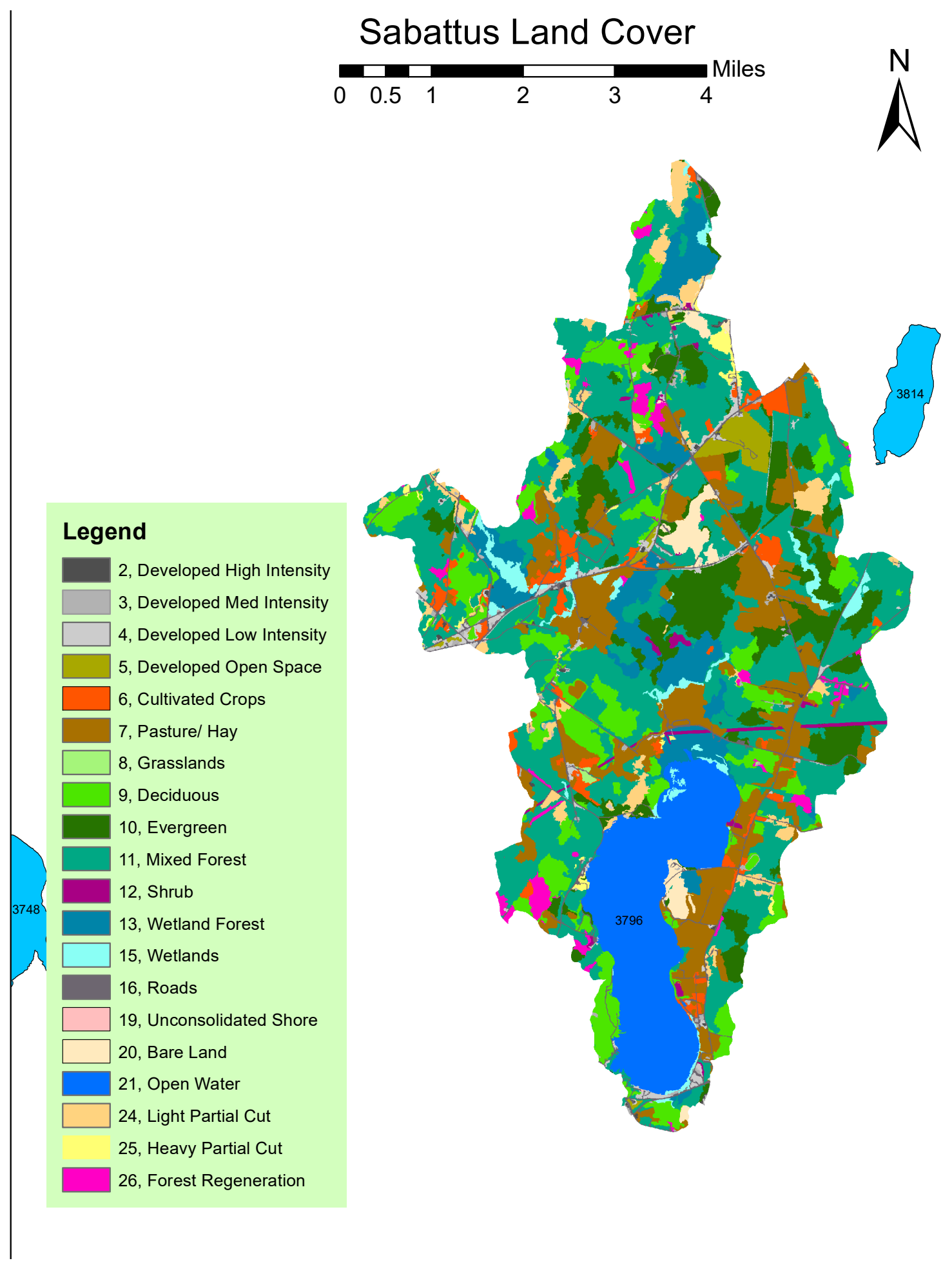


Figure F2: Continued

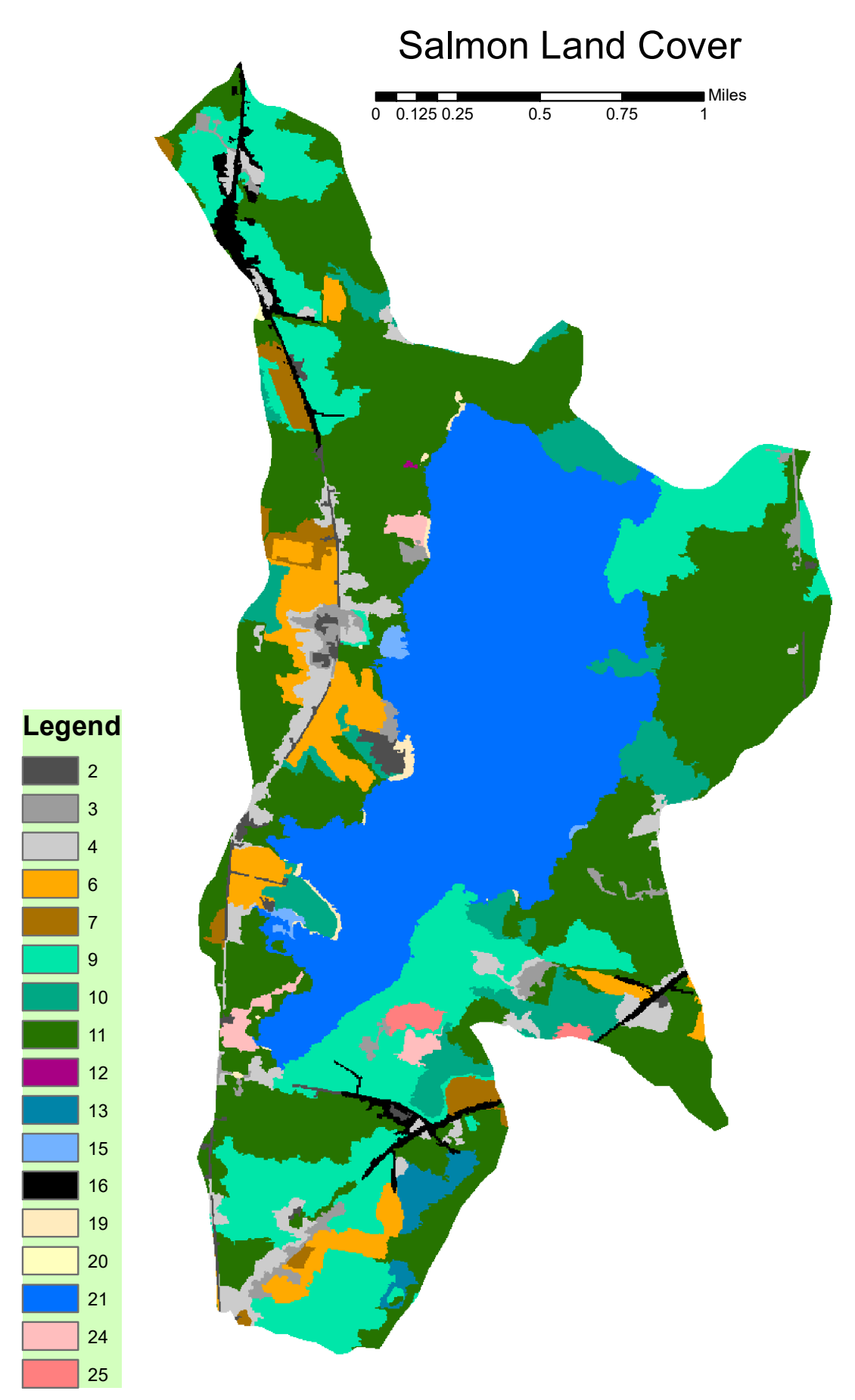

$N$ 
Figure F2: Continued

\section{Square Land Cover}

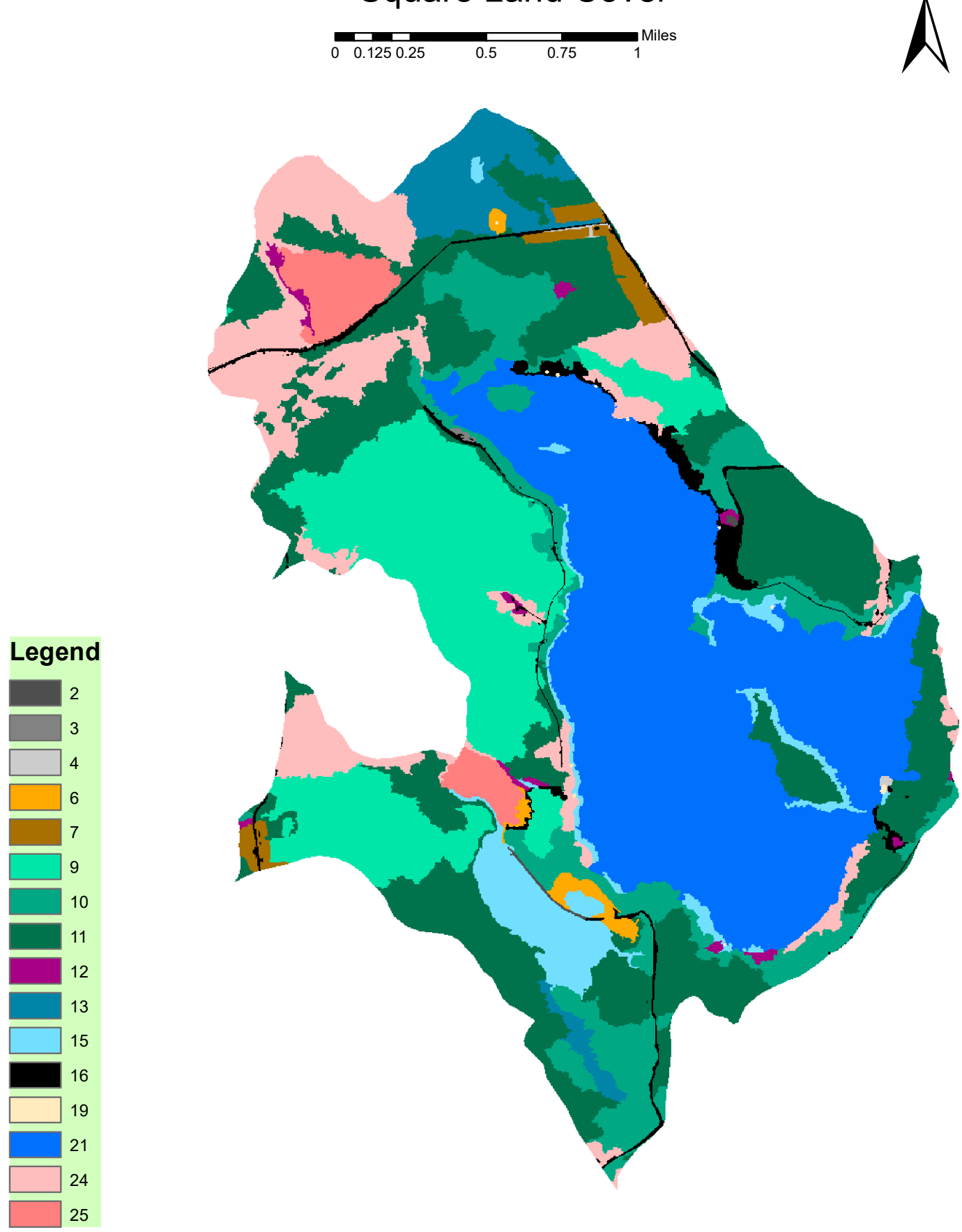


Figure F2: Continued

Taylor Land Cover

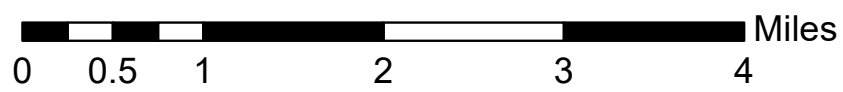

\section{Legend}

2

4

$\square 5$

6

7
$\square$
$\square$

10

11

12

13

15

16

$\square \quad 19$
$\square \quad 20$

21

24

25

26

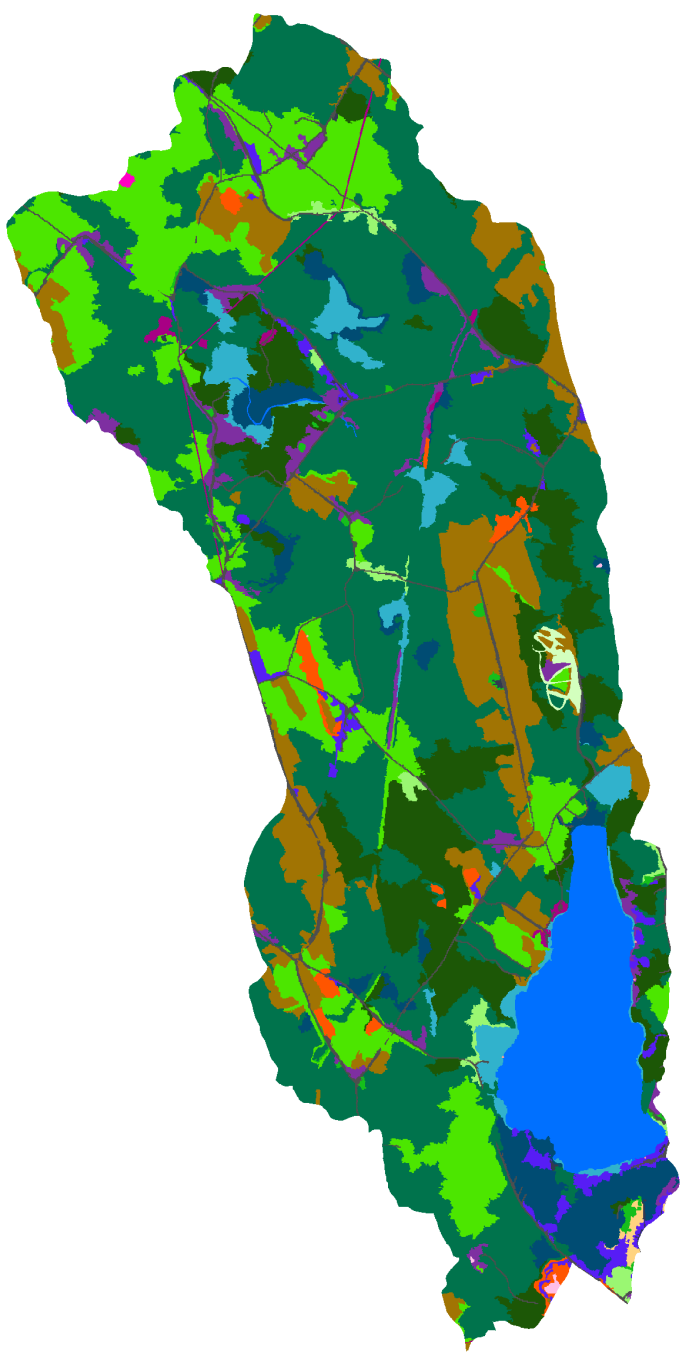


Figure F2: Continued

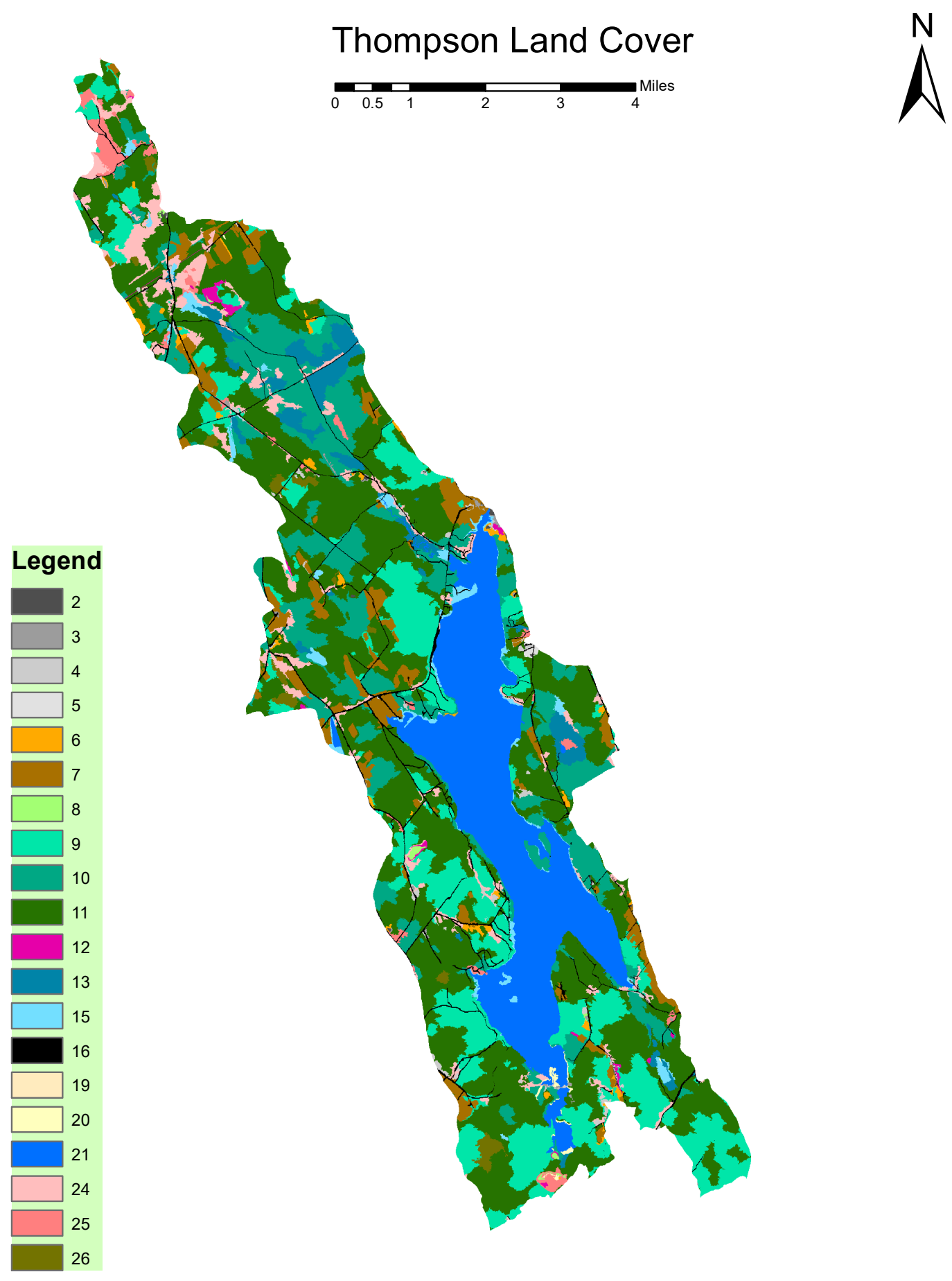


Figure F2: Continued

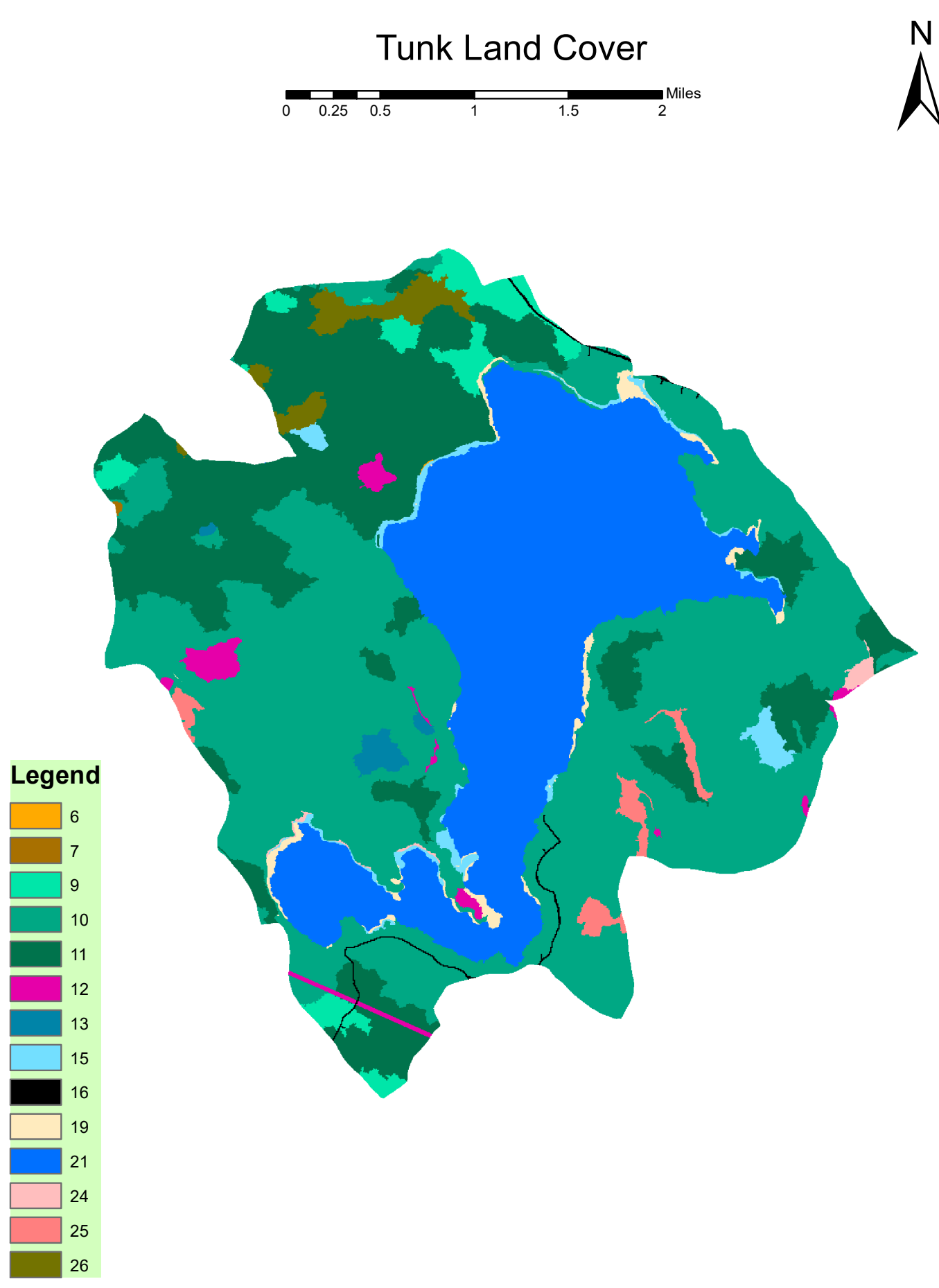


Figure F2: Continued

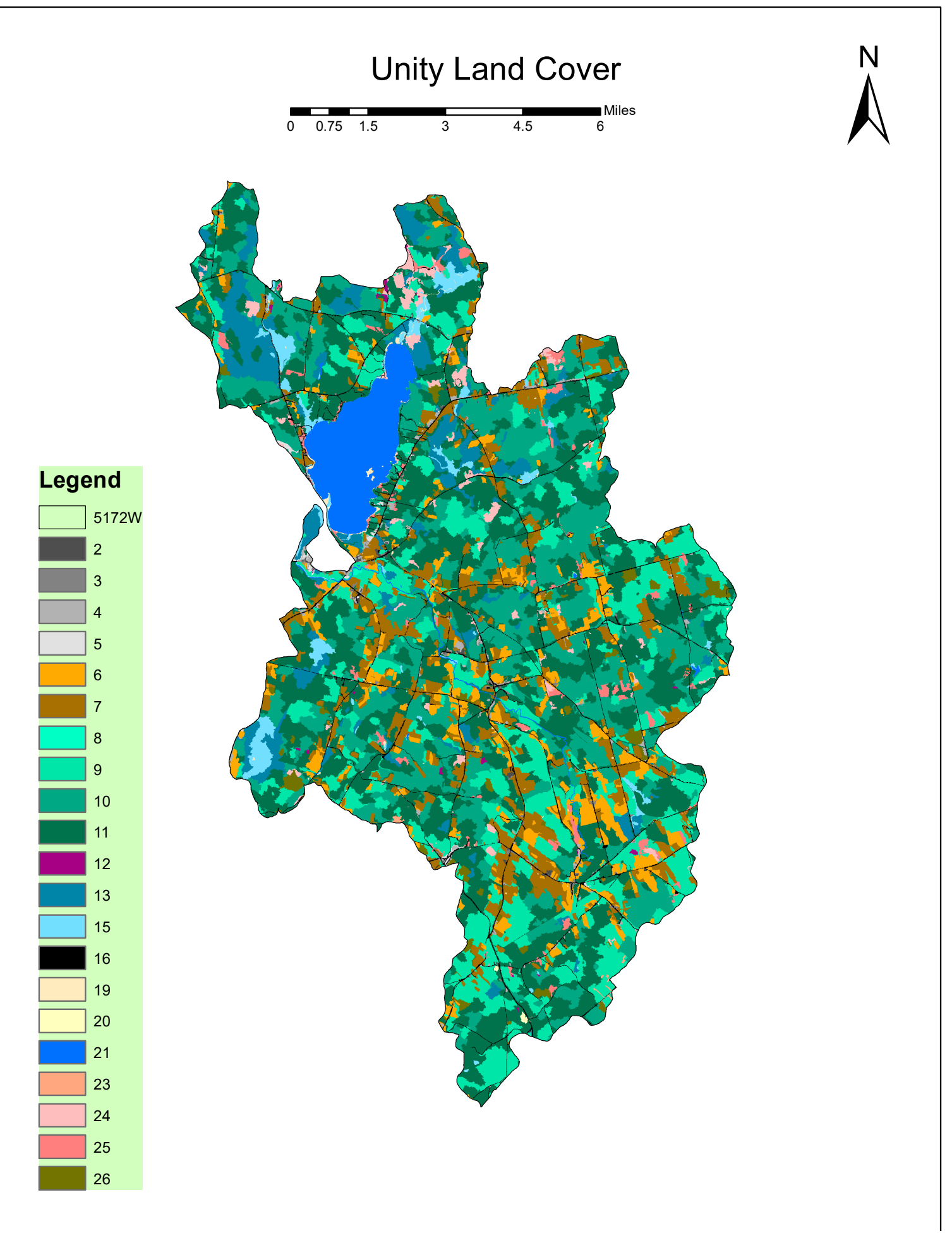


Figure F2: Continued

\section{Webber Land Cover}

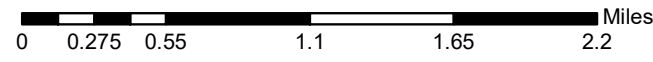

\section{Legend}

\begin{tabular}{|c|}
\hline $5408 W$ \\
\hline 2 \\
\hline 3 \\
\hline 4 \\
\hline 5 \\
\hline 6 \\
\hline 7 \\
\hline 8 \\
\hline 9 \\
\hline 10 \\
\hline 11 \\
\hline 12 \\
\hline 13 \\
\hline 15 \\
\hline 16 \\
\hline 19 \\
\hline 20 \\
\hline 21 \\
\hline 24 \\
\hline 26 \\
\hline
\end{tabular}

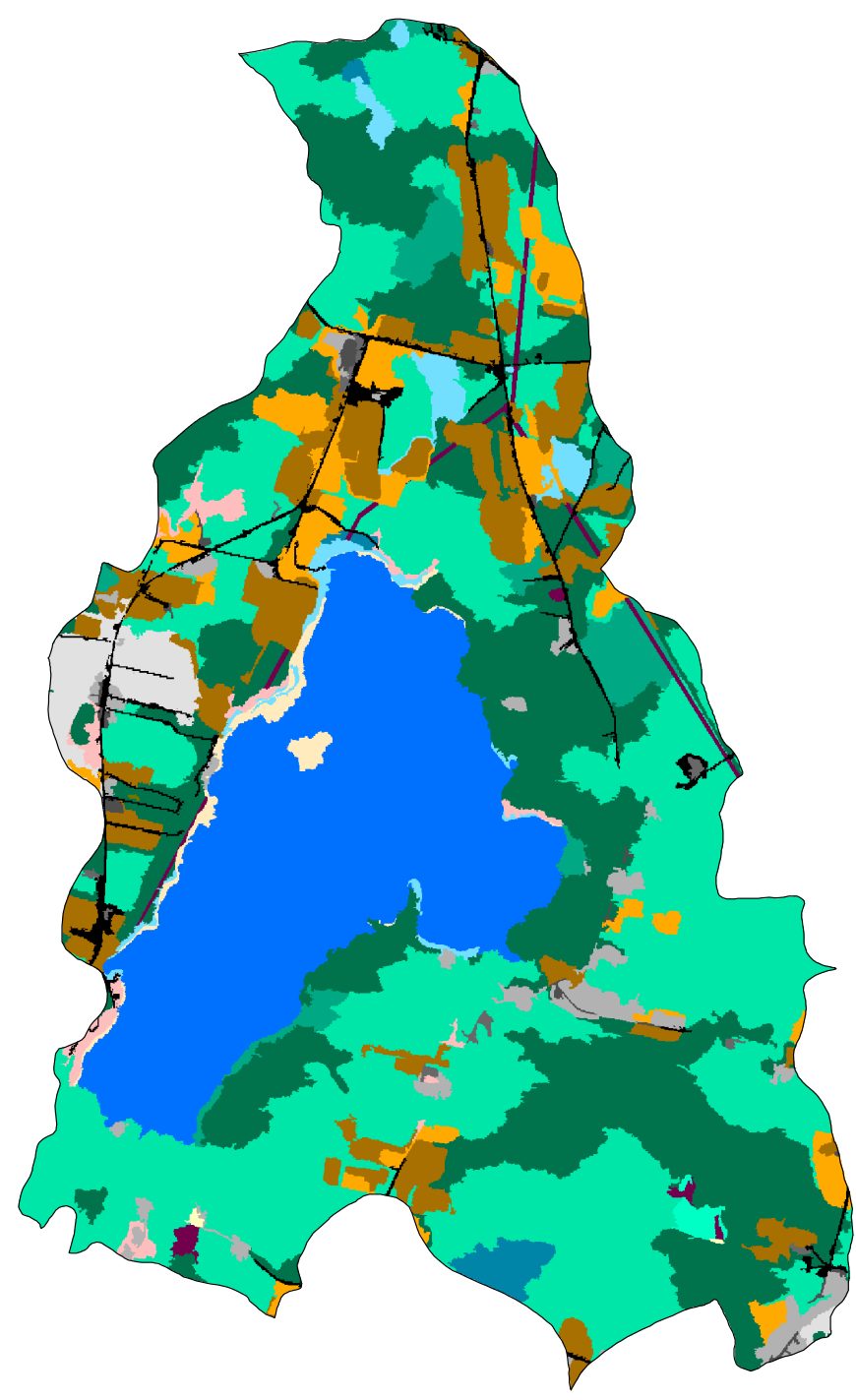




\section{BIOGRAPHY OF THE AUTHOR}

Kaci Fitzgibbon was born and raised in Marion, Ohio on July 5, 1993. She graduated from Pleasant High School in 2011 and graduated from Kent State University in 2015 with a Bachelor's of Science in Geology. She is a candidate for the Master of Science

degree in Earth and Climate Sciences from the University of Maine in December 2017. 